UC-NRLF

\title{
THE GRAPE:
}

How to Plant, How 10 Drow, How to Market.

$$
\frac{m}{m} \frac{m}{m} \frac{1}{m}
$$




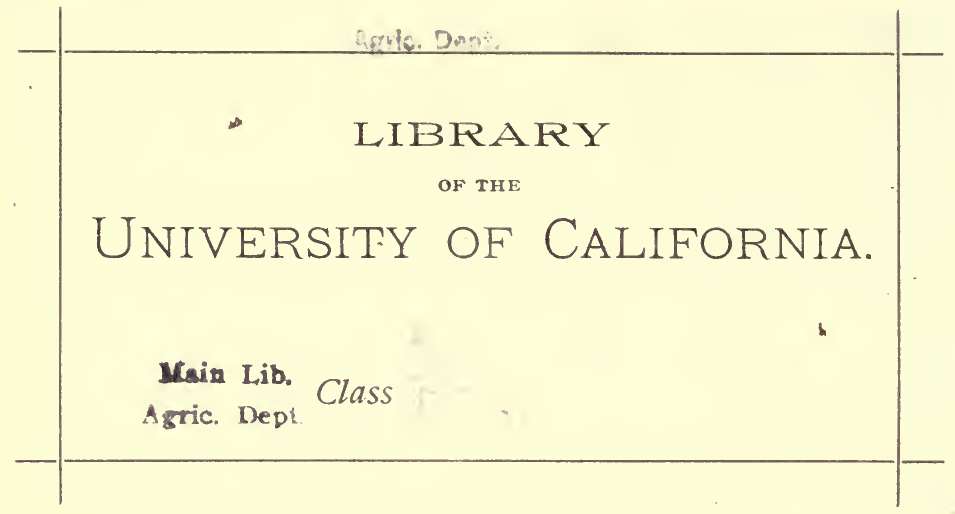









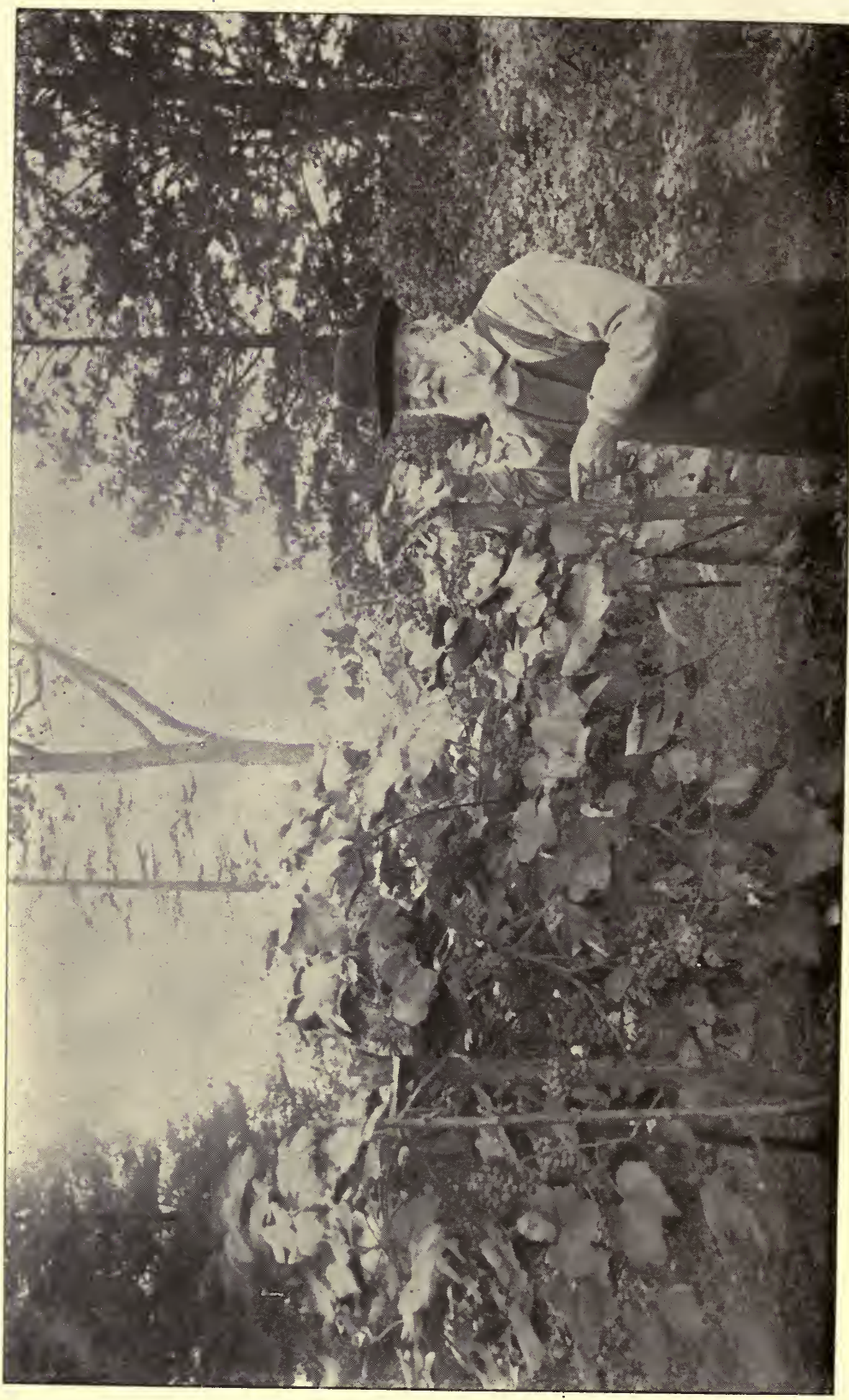

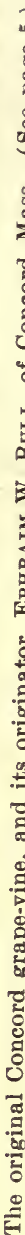




\section{HOW TO GROW AND USE. AGRICULTURAL LIBRARY, \\ UNIVERSITY $\rightarrow$ OF- \\ CALIFORNIA. \\ THE GRAPE IN KANSAS.}

The oldest cultivated fruit. The finest of all table fruits.

A fruit too good to be made a chief source of the degradation of the race as an alluring (yet intoxicating) principle.

To the glory of Kansas, $99 \frac{1}{2}$ per cent. of this luscious fruit which grows freely all over the state is used without fermentation.

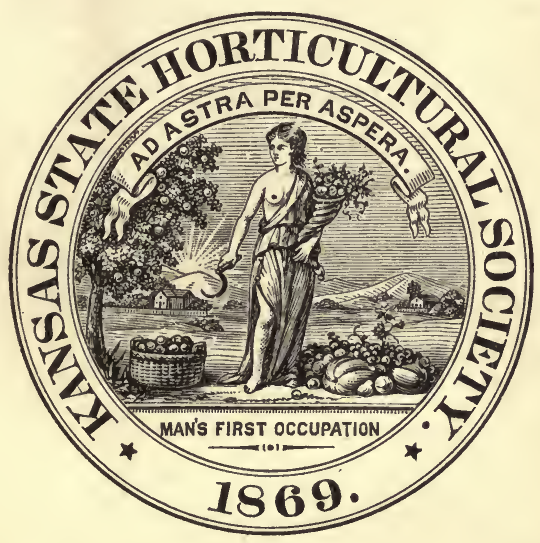

COMPILED AND REVISED FOR THE

KANSAS STATE HORTICULTURAL SOCIETY,

By WILLIAM H. BARNES, SECRETART, State Capitol, Topeka, Kan.

ISSUED BY THE STATE,

1901. 


\section{SB 389 K3}

Main I.th

Agric. Dept,

PRESS OF

W. Y. MORGaN, State Printer,

TopeKa, 1901. 


\section{THE GRAPE.}

\section{PROBABLY THE OLDEST OF DOMESTICATED FRUITS.}

"Cyclopedia of American Horticulture," by L. H. BAILEY.

It is probable that wine was made from it even before the species was brought into cultivation. It seems to have been cultivated at the dawn of history. Its product was certainly no rarity in Noah's time.

Of all countries, North America is richest in species of Vitis. These species range from ocean to ocean and from the British possessions to the tropics. The greatest development of the native-grape industry has taken place in New York and Ohio, bordering lakes and large streams. These areas are the lower Hudson river valley; the region of the central western New York lakes; the Lake Erie region of New York, Pennsylvania, and Ohio. There are also important grape interests in Ontario, Michigan, and other northern parts. There is considerable interest in grape culture in the cooler parts of Georgia and Alabama, and there are enlarging areas in the country extending from the Ozark region southward. Nearly all the country, excepting the northernmost parts, raises grapes, but in most cases the growing of them cannot be said to be extensive enough to be called an industry.

Although the grape sections of the North hug the water areas, and the land, therefore, is often steep, all grape growers prefer nearly level land. The old-world plantations are largely on very steep lands; such lands, by virtue of their warmth and drainage, are thought to give an extra quality of wine. These ideas were brought to this country, and many of our early vineyards were planted on terraced slopes. But we grow grapes for a different purpose from the Europeans, and land is cheap and labor is dear. Old-world methods cannot be followed in American commercial plantations. The ideal bunch of grapes is one which is of medium size for the variety, compact, uniformly developed and ripened thoroughly, containing no small or diseased berries, and with the bloom intact. '

A very dense or crowded cluster is not the most desirable, for all the berries cannot develop fully, and the cluster is not easily handled when the fruit is eaten.

Unfermented grape juice is a product which deservedly is growing in popularity. The lack of secondary domestic uses of the grape is one reason for the very serious gluts in the markets. However, one year with another, the profit on a good vineyard may be expected to exceed that on the staple farm crops. 


\section{ORIGIN OF AMERICAN GRAPES.}

From Bulletin No. 46, by Prof. J. C. Whitren, Horticulturist of Missouri Agricultural Experiment Station.

Nearly all the cultivated grapes of the United States east of the Rocky mountains originated from various native species found growing wild by the early settlers of the country. Improvement of these wild grapes began by planting the seeds of the best of them and by cultivating and selecting the best of these seedlings. From the most promising of these cultivated vines seeds were again taken and planted, and so on until some of our cultivated varieties are many generations removed from the wild vine with which improvement started. As these seedling generations began to be cultivated they became more variable than the wild vines from which they descended, and improved forms appeared. Whenever a vine exhibited any particular merit it was propagated by means of cuttings, given a name, and became known as a cultivated variety. In some cases wild vines have been found possessing sufficient merit to warrant their being propagated and named as distinct varieties. Neosho and probably, also, Cynthiana and many others have been propagated directly from vines found growing wild in the woods. Improvement of our native grapes has progressed so rapidly in recent years that we now have more than 1000 named varieties in cultivation, though but few of these varieties are known to the average cultivator. Since our grapes may be grouped or classified according to the species from which they sprang, a brief description (from a horticultural rather than from a botanical standpoint) of the species represented by the varieties mentioned in this bulletin is here given.

Our grapes are referred to the genus Vitis, comprising numerous species, among which the following will be considered:

The Northern Fox Grape. Vitis labrusca Linn.- Native from New England to South Carolina and from the Alleghany mountains eastward to the coast; not known in a wild state in the Mississippi valley; is the parent species of more than one-half of our cultivated grapes, including the Concord, Hartford, Catawba, and Niagara. Distinguished from all other species by its continuous tendrils or inflorescence - that is, having a tendril or flower cluster opposite each leaf; while other species have intermittent tendrils - that is, two leaves each with a tendril opposite it, and then a third leaf with no such tendril. The fruit clusters of the grape occupy positions corresponding to those of the tendrils, hence, on account of this continuous arrangement, grapes of the labrusca species often bear three or more clusters of fruit in succession on the same branch, while other species bear only two clusters of fruit in succession, the third leaf having no tendril or fruit cluster opposite it. The leaves of labrusca are large, thick, and very cottony beneath, especially while young. It has, generally, very large berries and large bunches. Except when hybridized with some other species, its fruit usually has a distinct musky flavor.

This species, which has produced more cultivated varieties than all other species combined, is generally regarded as occupying the most important position in the make-up of our American grapes. Its numerous varieties furnish grapes of every shade from white to red and black, of every quality from bad to good, and of various seasons, from the earliest to the latest. A single one of its varieties, Concord, is more largely planted and marketed than all other varieties, and when we include Moore's Early, Worden, Wyoming Red, and other popular sorts, it will be seen that the bulk of American grapes grown and marketed east of the Rocky mountains belong to this species. While various cultivated varieties of 
this species succeed well in Missouri, and will probably long continue to be important here, it should be borne in mind that they are not so capable of enduring our summers, particularly if the season be dry and hot, as are some of the species that are native to this region and to the south and west.

The River Bank Grape. Vitis riparia Michx.-This species is of wider distribution than any other native American grape, being found along the streams in southern Canada and many parts of the United States east of the Rocky mountains. It extends farthest north, and is the hardiest of our grapes. It is the parent of Clinton; Bacchus, and other well-known varieties. A's these cultivated varieties indicate, its fruit is small in both bunch and berry. It may be distinguished from other species by having very thin diaphragms at the nodes of the stem, small, light green, shiny glabrous leaves, almost or quite without hairiness beneath, large stipules, and very early flowering habit. This species, with some of its cultivated varieties, has become of great importance in European vineyards by furnishing a phylloxera-proof stock upon which to graft the European varieties. The vines of this species are rank, tall, straggling growers. They are readily propagated by means of cuttings. While grapes of this species are reasonably free from rot, they are more susceptible to the attack of leafhoppers than other species. During certain seasons varieties of this class have their foliage almost entirely destroyed by this insect when other species in the same vineyard are injured but little. In fact, the attacks of this insect on varieties of riparia are a serious drawback to its successful culture in this section. In the number of cultivated varieties which this species has furnished it ranks next to V. labrusca.

\section{THE ORIGINAL CONCORD GRAPE-VINE.}

By Chas. E. Newlin, in Indiana Farmer.

I thought your readers might be interested in a little horticultural history which has been of great interest to me. Perhaps few of those who annually feast on the luscious Concord grape ever stop to think where the variety originated or when or by whom it was first cultivated. An hour's ride northwest from Boston, through historic old Cambridge and Lexington, is the quaint little, scattered town of Concord, where the first battle of the revolution was fought, April 19, 1775, though the little skirmish at Lexington on the way out here is usually given that distinction. After a walk out two miles over the fir-covered hill to Walden pond, where Thoreau's happy hours were spent in the little hut on its shores, and back to a New England dinner in Wright's tavern, built in 1747 and used ever since as a tavern (it was here the English general, Pitcairn, got drunk before the battle of Concord), I wandered out the old Lexington road past Emerson's home, where his daughter still lives, and past the Alcott home, where "Little Women" was written, and in whose door-yard, by the foot of the hill, stands the plain, unpainted "Concord school of philosophy."

A little further on is "Wayside," the "House of Seven Gables" (and it has them), where Hawthorne wrote "Scarlet Letter" and where his daughter, Mrs. Lothrop, still lives. Next door to this historic house stands Bull's cottage, in whose door-yard still grows the first Concord grape-vine, from which stock the unnumbered millions of vines of this variety came. [See frontispiece to this book.] The vine is now enclosed in close latticework, around and above, to keep vandal relic-hunters, like myself, from carrying it away by inches. On one side hangs a square oak board on which these words are burned most artistically :

"I looked about to see what I could find among our wildings. The next thing to do was to find the best and earliest grape, for seed, and this I found in an ac- 
cidental seedling at the foot of the hill. The crop was abundant, ripe in A ugust, and of a very good quality for a wild grape. I sowed the seed in the autumn of 1843. Among them the Concord was the only one worth saving.-EPHraIM WALES Bull."

This is the simple story of the origin of the greatest grape ever produced.

Mr. Bull was born March 4, 1806, and died September 26, 1895. Mrs. Lothrop then bought the grounds of her father's old friend, and is keeping the quaint old cottage and its surroundings in perfect repair, just as Mr. Bull left them, except for a little addition to the back for accommodation of the renter. On the mantelpiece in the sitting-room she has had daintily painted this "confession" of $\mathrm{Mr}$. Bull:

"I confess I did not expect to arrive at so great a success so soon, but when I had the good fortune to find the Concord among the first crop of seedlings, the thought dawned upon me that in the perhaps far-off future higher success awaited the cultivator who had the patience to wait, I had almost said also the courage to venture, for I was sensible that any attempt to improve the wild grape would be considered an imputation upon the judgment and sagacity of the Creator. Fully aware of this, I kept my own counsel, and if I had not succeeded nobody would have known that I had ventured."

And above the old fireplace in the dining-room is painted:

"Final summing up of thirty-seven years' work, from over 22,000 seedlings, twenty-one grapes which in the light of to-day I consider valuable. I had at one time 125 vines which I thought worth saving, but, grown more critical with every new success, I have discarded most of them."

What a world of patience and love of his work this discloses; I was told by one of Mr. Bull's old neighbors that the original wild grape which was found ripening in August Mr. Bull found on the banks of Concord river, just a little above the old bridge where the battle of Concord was fought, and where now stands that marvelously beautiful statue, "The Minute Man," on the base of which is carved:

"By the rude bridge that arched the flood, Their flag to A pril's breeze unfurled, Here once the embattled farmers stood, And fired the shot heard round the world."

Just across the meadow on the little hill stands "The Old Manse," sacred to all lovers of good literature.

Knowing the classic surroundings of the birth of the Concord grape, perhaps some of our readers will enjoy a little more the refreshing fruit from their own vine descended from this parent vine, which old Ephraim Wales Bull gave to the world fifty-eight years ago.

\section{EVOLUTION OF THE AMERICAN GRAPE.}

"Evolution of Native Fruits," by Bailey.

The first American grape introduced was the Cape or Alexander, found wild in the woods of Pennsylvania. The Catawba was found in the woods in South Carolina, and introduced by John Adlum, of the District of Columbia, in 1802. The Concord was found by E. W. Bull, in his garden in Concord, Mass. Worden is a seedling of the Concord. Delaware was found in the garden of a Frenchman in New Jersey. Brighton was produced by crossing the Concord and Diana -Hamburg (a hybrid) by Jacob Moore, then of Brighton, N. Y. Diana came from a Catawba seed, at Milton, Mass.; Moore's Early came from a Concord seed; Clinton came up at Clinton, N. Y.; Norton's Virginia, a Virginia wildling 
of 1835. Rogers's hybrids created a great stir. T. V. Munson, of Texas, is doing a great work in cross-fertilizing and growing hybrid grapes. Most of these hybrids obtain their excellent qualities from some of the European, and their vigor and hardihood from their native American ancestry. Some are of second or even third crossings of hybrids on hybrids, or hybrids and European on native. The American hybridizer cares little for ancestry, excepting as it adds an element of anxiety and uncertainty to its influence, but he goes for a combination of certain desired qualities, and only partially successful, he goes still farther in the combination to remedy the defect; and this plan, while not scientific, is bound to succeed, because it has an aim, a goal, an ideal, and, with patience and perseverance, this ideal will be attained, if not set too high.

\section{STATISTICAL UPS AND DOWNS IN KANSAS.}

No reliable statistics of the acreage of vineyards in the counties were taken previous to 1881 .

In 1881, we find Doniphan county in the lead, with 384 acres. It was also tirst in acreage in '82, '84, '85, '89, '91, '92, and '93, with varying acreage, from 414 to 567. It was second in ' 87 , '96, and ' 98 , with 480 and 537 acres, respectively. It was third in '83, '95, '97, '99, and 1900, with 414, 457, 497, 450 and 351 acres, respectively; fourth in ' 86 and ' 94 , with 335 acres and 308 acres, respectively. Thus Doniphan county was first in acreage for ten years, second for three years, third for five years, fourth for two years, standing third in 1900, with 351 acres.

Washington county was reported second in 1881, with 293 acres, and in '95, with 252 acres, but did not hold out, and is now (1900) reported with only 84 acres, being twenty-second in rank.

Douglas county was third in 1881, with 206 acres. It has varied in standing from third to seventeenth, with from 134 to 239 acres, ranking now (1900) twelfth, with 157 acres.

Leavenworth county was fifth in 1881, with 181 acres; in '98 it ranked third, with 232 acres. Its greatest acreage was in '93, when it ranked fourth, with 274 acres. In 1900 it ranked tenth, with 167 acres.

Sedgwick county came to the front in 1894, ranking first, with 445 acres; also ranking first in '96, with 565 acres. In '89, '91, '92, '93, '97, '99 and 1900 it ranked second, having now (1900) 404 acres.

Wyandotte county was ninth, with 147 acres, in 1881, and has never fallen back much, although in 1888 it ranked thirteenth, with 164 acres; it was in the lead, ranking first, in 1895, '97, '98, '99, and 1900, varying from 550 to 709 acres, with 1900 at 538 acres.

Nemaha county claimed second place in 1884, with 393 acres, and third place in 1886, with 391 acres, falling back to fourteenth place, with 131 acres, in 1900 .

Chase county got third place in 1885 , with 212 ; stands now (1900) No. 42 , with only 24 acres.

Saline county got third place, in 1891 , with 348 acres, but went back to thirtyfirst place, with 51 acres, in 1900.

The above ups and downs, covering nine leading counties, while they possibly point out the best localities for successful grape growing, do not indicate that grapes will not do well elsewhere. Grapes grow readily from cuttings, and many people once put out large tracts so located that they had no market; thus grapes became very plentiful and cheap, and the vines were neglected and the acreage fell off.

To-day - 1900 - the leading counties are: Wyandotte, 538 acres; Sэdgwick, 404 acres; and Doniphan, 351 acres. 


\section{PROPAGATION BY SEED.}

New varieties of the grape can only be obtained by propagation from seed. Many of our prominent and useful varieties were accidental seedlings that fell into the hands of wise and careful horticulturists. But many vineyardists are applying themselves to the propagation of grape-vines from seed of known parentage, the blossoms being fertilized by hand and seed thus obtained carefully labeled, and the little seedlings tended to in a most solicitous manner.

In Kansas our fruit should be like our people, vigorous and up to date; therefore do not plant grape seeds from vines of any but the best varieties, of vigorous growth, strong, thick foliage, free from mildew, and hardy; also be sure the grapes are ripe. Do not even then expect too much. Grape seedlings are not like grape cuttings, and are often frail, delicate, and puny, requiring your close attention until they are able to cope with the world. Another thing: do not pull up the weaker or delicate ones as soon as a few vigorous ones come into bearing; the chances are that the delicate and backward ones may have the better fruit. The vigorous early bearers may take after a wild ancestor.

\section{PROPAGATION BY CUTTINGS.}

\section{From Colman's Rural World.}

In pruning vines, the wood of which I wish to propagate, I merely cut loose from the trellis, cut out the old wood that is to be abandoned, and cut the lateral branches and tendrils off ; then, afterward, cut them to the proper shape, carrying the wood in canes to the house to dress the cuttings ready for planting, which I have often done in the fall with success. Owing to the danger of having them heaved out somewhat by frost, I have for many years planted them out in the spring. Make the cuttings six to ten inches long, according to the joints, as a cutting should have two or three eyes, and some short-jointed varieties may have four or five eyes. Cut under the lower bud, at right angles with the bud [that is, square across] and one-half inch above the upper bud. Tie in bundles of 100 or 200 each and bury, covering about six inches with earth. Some recommend burying them upside down, but I have found that it makes but little difference whether right or wrong side up, or lying horizontal. If the wood is sound when put in, the cuttings will come out all right in the spring.

As soon as the frost is out of the ground in the spring, and it is dry enough to work well, they may be planted in rows three feet apart, and from three to six inches apart in the rows. Make a slanting trench at an angle of forty-five degrees, deep enough to hold the cuttings, so that the upper eye will be half an inch under ground when the earth is leveled. When the cuttings are laid in, always have the top bud on the upper side, so that the shoot can start straight out, fill the trench over half full and tread the ground firmly, then fill in the rest of the soil loosely. Of about 10,000 put in last spring, not five per cent. failed. These are as fine a lot of plants as I ever grew. The astivalis class is difficult to grow from cuttings, and these are propagated by layers. [See elsewhere.] At times, when ready to set out my grape cuttings, I found the base of them calloused, and the buds swollen, ready to burst. When in this condition, they should not be exposed to the sun or air any length of time. 


\section{PROPAGATION OF GRAPE-VINES BY LAYERING.}

Layering is a method of raising young vines by burying a branch of an old vine while it is still attached to the original root. The plan is especially desirable for growing vines which do not root readily from cuttings, as well as to get bearing vines quickly. Layers usually fruit at least a year soorer than those grown from cuttings. Strong canes of well-ripened wood should be selected, choosing those that can be bent to the ground without breaking. The soil should be dug away to a depth of two or three inches and the cane laid into the trench with the end left out. The cane should be fastened down firmly with pegs and be covered with only a small depth of soil, perhaps an inch at first. The work is usually done in June, but can be done later if water is given occasionally, so the young roots will not dry out. At every joint of the covered cane roots will start out, and the latent buds will develop into new shoots. Not all should be allowed to grow, however, as there is not sufficient strength for all; so the rankest-growing shoots are selected and the other ones broken off, only about half that start being allowed to grow. When the shoots are a few inches in height stakes should be provided, as the growth is much more rapid when support is given them. When the shoots get nicely above ground a little more soil may be hoed around them every time they are cultivated, until the trench is a little more than even full. The reason for filling it up slowly is because, if too great depth of earth is over the cane at first, it will be liable to rot. These layered vines should be cultivated once a week until late in the season, except there should be a period of very dry weather, when it might be best to mulch them heavily with strawy manure and give up cultivation for the rest of the season. In late fall the young plants can be separated and set out in the vineyard, or stored in a cool cellar till spring.

\section{SPRING AND SUMMER LAYERING, AND ·HOW PERFORMED.}

Layering is the simplest, surest and easiest method of increasing the grape, and is the best way to grow vines where only a few are wanted. There are two kinds of layers, called spring and summer layers, from the season at which they are made.

Summmer layers are made in the summer, generally the last of July, from a branch of the same season's growth. They are likely to be weak for several years, and do not make as good plants as the spring layers. In making them the wood should be slit for an inch or so near the buds that are covered. Bury about one foot of the cane four inches deep in the ground and it will be rooted by late autumn, when it should be separated and be treated as a young vine, and it is generally best to get them well started in a garden or nursery before planting in the vineyard permanently.

Spring layers may be made by laying down any cane early in the spring. It will root in one season. By fall it will have made a good growth of roots, when it may be cut from the main cane, and, if strong, it may be divided into two plants. By a little different treatment of the spring layer a vine may be grown from each bud on the layered cane. For this purpose some thrifty cane should be selected in autumn, pruned of its laterals and buried. In the spring it should be uncovered and only one shoot permitted to grow from each joint. 
After the new growth has started about six inches from each bud the whole cane should be layered about four inches deep, handling it carefully, so as not to break the new growth.

It is a good plan to cover it not more than three inches at first, and to fill up the trench as the shoots grow. If covered four inches deep at once, the young growth will sometimes rot, though this seldom happens, and some skilful growers fill the trench full at once. In the autumn roots will be found growing from each joint, and these may be cut apart. If this method of propagation is used to some considerable extent, vines should be grown especially for the purpose. It is not a good plan to use fruiting vines for layering, though it may be safely done in a small way, says a Farm and Fireside writer, in concluding the advice here reproduced.

\section{SUCCESSFUL GRAPE GRAFTING.}

An old Clinton vine stood at the corner of the woodhouse which was so vigorous that its branches spread over everything within reach, but bore no fruit. In April, 1896, I cut branches off close to the ground and grafted in a Delaware grape and an Iona. I used no wax; simply wrapped carefully with strings of cloth, pasted a little mud over the wounds, and covered all with earth except the top buds of the grafts. Those grafts made a wonderful growth the first season, owing to the far-reaching roots of the Clinton vine. At close of the first season the Iona vine was about eighteen feet long and the Delaware about twelve. This season, with the vines one year old, the Delaware branch bore twenty-four as fine bunches of grapes as I ever saw. The bunches and berries were slightly larger than the Delaware generally grows and so compact on the stems that they could not be picked off easily without beginning at the end of the bunch.

The Iona branch bore about forty bunches of Iona grapes of the finest quality. This is a quick way of getting a grape-vine into bearing. I tried the same experiment on a wild grape-vine down in the pasture. It grew just as vigorously, but an inquisitive Jersey cow spoiled the experiment.

\section{PRUNING THE GRAPE.}

In pruning fruit-bearing trees, we prune for shape and to let in sun and air. In pruning the grape, the essential point is to lessen the growth to save the vine from exhausting itself, and either dying in its efforts at producing a'prodigious crop or producing inferior fruit or small clusters. On a grape-vine three or more years of age, in Kansas, we can rely upon every healthy bud producing a shoot, and most of these shoots bringing to light three or more clusters of embryo grapes. Unless thinned theseare more than any vine can properly mature. The best way to thin grapes is by pruning the vine at a time when it will be least injurious - from November to March is the time; and as you can count on a vigorous, thrifty vine doing its part, you should leave about one-third as many healthy buds as the number of bunches of grapes you think the vine can or ought to mature. As grapes will average four or five bunches to a pound, and a vine may bear from twelve to thirty pounds, it is easy to calculate about how many buds to leave. If you prune on the arm and spur system - that is, arms of previous year's growth to be tied to the trellis, and spurs made of last year's growth, cut 
to within two buds of the arm - you can readily count your next year's grapes at pruning time. No other fruit will come so near to the grower's calculation if he prunes with an object. Haphazard pruning will not tend to productiveness.

The grape is a wonderful renewer, and strange as it may sound, the more you cut away, up to a certain limit, the finer and more plentiful the fruit. The aim the first year is for root growth; therefore one cane as near the ground as possible is all that should be left to grow. In congenial ground and favorable weather this cane will grow long, strong, and vigorous. If it grows weakly, then at pruning time cut it within three buds of the root and let only one cane grow the second year. If it was vigorous the first year you may let two canes grow the second year, and if you want these canes to be first class and useful, rub off all other shoots as they start. At pruning time, November to March, after the second year, cut the two canes anywhere from four to six feet from the main stem, and tie them apart like the letter V, or wide apart on lower wire, according to style of trellis used. In spring every bud will break into a thrifty shoot and several will produce fruit. After this you can keep the arms and prune the new growth back to two buds. You can also grow two additional arms from near the fork if you wish.

Your spurs with two buds each will produce fruiting shoots, and at pruning time you cut away the upper one and cut the lower one back to two buds. This is all there is to the arm-and-spur system. You can add two more arms, making six or even eight, as the vine grows older, and the arms may be of such length as will cover a trellis to suit; a ways remembering to provide room for the new shoot that is sure to come from each healthy bud. The renewal system grows new arms each year, and at pruning time cuts away two or more of the older arms. If you have $\mathrm{s} x$ arms, two are $\mathrm{n}^{\mathrm{m}}$. $\mathrm{u}$ have borne one crop, two have borne twice. These latter will be cut away and two new ones grown the following year. This system also uses the spurs on its older canes.

If you would summer prune, do it on this wise: Rub off all irregular or weak shoots; then, after the fruit-buds show the cluster formation and the shoot continues to grow, clip off the end one or two leaves or joints beyond the last bunch. Soon after, the axillary buds at the base of each leaf will start; pinch them off. The Germans call these thieves, as they claim they rob the bunches of nutriment and deteriorate their quality. This is all there is to summer pruning.

\section{PRUNING GRAPE-VINES.}

Great care should be taken in pruning grape-vines, and at a certain time of the year, in order to get the best results from them. My experience has taught me that the last of November or the first of December, after the leaves have fallen and the sap has gone down to the roots, is the best time.

Then cut the new wood back to two joints of the wood that grew during the previous season. One joint is better than two, but it is not safe to cut so close as that at this season; the vine, being so porous in the end when it is cut, will take in water then freeze and split. Sometimes it will go through the first joint, so as to spoil it to start in the spring. It is in these joints where the new shoots start out to grow, and if split by the frost will spoil that part of the vine. For this reason it is better to leave two joints and be safe. Some may say, Why not wait until spring, then cut back to one joint? I have tried both ways, and I do not get as good results in the spring as in the fall. For this reason we want to be sure and do it before the sap begins to go up, so the wood 
will have a little time to dry and season at the ends, or a great loss of sap will be the result, and your vine will be weakened thereby, and your crop will be small in quantity as well as quality.

Oftentimes in the early spring we have a very warm spell for two or even three weeks, and the sap will start to go up the vine and buds will begin to swell, and will look as if they were ready to open in a few days more. Then it will come on cold again, but the sap will not go down again until it has put forth leaves, as nature's laws have so provided. Then, if you cut your vines there is a loss in sap and vitality, which causes the vine to be injured. When the branches start to grow they should be trained up on building or trellis, and not allow more than two good clusters on a single shoot; if you do they will be small, and will not fill out well and be more or less imperfect. After the little grapes have set, then the top end of the shoot containing the grapes should have about two inches. pinched off. This will check the growth of the vine and throw more strength and vigor into the clusters and make the grapes larger and better.

\section{GIRDLING AND PINCHING GRAPES.}

By J. C. Whitten, Columbia, Mo.

The subject of girdling and of summer pinching of the vine is a sufficiently large one, and discussion of it may not be amiss.

We have in the experimental vineyard, at this writing (July 30 ), girdled grape shoots bearing fruit that is turning color, while the fruit on normal shoots of the same vine is entirely green. Girdled peach branches are bearing fruit that is much larger and nearer ripe than normal branches on the same tree. Not only is fruit larger and earlier on branches of vines and trees that were girdled this summer, but certain apple trees on the experimental grounds bore blossoms and set fruit this year on branches that were girdled last year, while none of their normal branches had any flowers at all. The effects of girdling a fruit-bearing branch to increase the size and hasten the ripening of its fruit, and of girdling a non-fruitful branch to throw it into bearing the nextyear, are so well known that in some places the practice of girdling is quite common. At shows, fruit from. girdled branches is barred from competition with normally grown fruit, on account of the fact that it is expected to be of unusual size, though the branch. was destroyed in producing it.

Commercially, girdling is not much practiced, because, as noted by Mr. Bent, the branch just below the girdle is not properly nourished and weakens or sometimes dies from the effects of this operation. The reasons for the above will be. understood if briefly stated, as,follows:

The sap, when taken up by the roots, is not ready to directly nourish the tree, but is carried upward through the sap-wood to the leaves, where a part of the water is evaporated in to the atmosphere. In the leaves the food materials in the sap and the gases taken in from the air are elaborated (or digested), and are then ready to be distributed over the tree and to produce growth. This elaborated food is carried back in the growing or cambium layer to nourish all parts of the tree. A girdle does not injure the sapwood, and hence does not retard the upward movement of the crude sap. The same girdle does, however, destroy the soft-growing layer just inside the bark, and prevents the return of the elaborated food, which collects in the girdled branch and causes unusual growth, not only of the branch above the girdle, but also of any fruit that may be growing on it. As soon as a girdle is made, the plant attempts to heal over the wound. A press- 
ing downward of new tissue may soon be noticed above the girdle. If the ring of bark taken off was not too wide, it may heal over, and the elaborated food again begins to be carried downward to nourish the parts below. Unless the wound heals over, the parts immediately below the girdle suffer for want of food, and eventually die, thus destroying the whole branch.

Regarding the pinching of vines, since all the food of the plant is elaborated in the leaves, it would, at first thought, seem advisable to encourage unlimited growth and the formation of as many leaves as possible. As a matter of fact, however, judicious summer pinching of fruiting shoots is often advisable. Sometimes the tendency seems to be to center the energies of the plant in producing mere length of wood growth, and the energies of the plant are diverted away from nourishing the fruit and centered upon the production of leaves and canes. In such cases pinching back the growing point often checks wood growth and more of the elaborate food goes to nourish the fruit. Reducing the number of leaves too much, however, will undoubtedly prevent the elaboration of sufficient food, and the whole plant, fruit and all, will suffer. It is merely a question of so balancing the treatment that enough foliage will remain and still not encourage the vine to run to wood. The amount of pruning or pinching necessary varies with the variety, and also depends upon the soil, climate, and other conditions; hence, the grower should get the principles well fixed in mind and then adjust the treatment to suit his conditions.

\section{GIRDLING GRAPE-VINES.}

Among the many artificial expedients for making plants do as one wishes, that of girdling or ringing the grape, which is now and then practiced by horticulturists, is not the least curious and interesting. It consists of the entire removal of the bark just below the fruit cluster about a month before the time of ripening. Its effect is to hasten the ripening by a week or two, and to increase the size of the fruit. The sap ascends through the pores of the wood and sustains growth, but on descending the elaborated sap, which passes down between the wood and the bark, can go no lower than the point where the vine has been girdled. It stops there and goes to feeding the bunch of grapes growing at that point. Of course, ringing is a thing that can only be done to a limited extent, and the experiment can only be tried on scattering branches. It is evident that all that part of the vine below the cut will suffer the following year, and that the entire vine itself would be permanently injured and perhaps destroyed if the practice were made at all general. As an interesting experiment, however, to be made on branches that one thinks of removing anyhow, a trial of ringing will furnish an interesting study to those curious in such matters.

\section{GIRDLING GRAPE-VINES.}

The opinions of grape growers vary as to the advantage of girdling the grapevine to induce it to color and ripen its fruit earlier. Most of those who live in the best grape-growing locations are opposed to the practice, as it secures earliness and greater size of fruit at the expense of quality. The operation is performed by cutting a circle back of the new shoot below the first bunch, after the grapes have set. Before that time the new wood will not have firm enough bark to be ringed. The effect of ringing the branch is to stop the flow of sap back- 
ward to the root after it has gone to the leaves and has absorbed carbonic-acid gas from the air. The roots need this carbon as well as the leaves, fruit, and branches. If a vine were girdled thus near the ground, its roots would have their supply cut off and would perish. That would kill the vine. Usually, however, only one or, at most, two shoots on a vine are girdled, and as these are all cut away in the fall pruning, no harm results to the vine. Where the ringing of the shoot is done there is a material enlargement of the shoot, caused by the returning sap. Some of this goes into the fruit, causing it to grow to a larger size. But there is too much of this sap for the good of the grapes, which taste as if they had been grown in a wet, cloudy summer. The highest flavor of grapes can only be secured where there is an unobstructed flow of sap back to the root, so that they do not get too much of it. Still, if you have rarieties that will not ripen in your section, it may pay to ring some, for a grape thus artificially ripened is far better than one that remains green until frost stops further ripening.

\section{HOW RINGING AFFECTS GRAPES.}

Ringing grapes is practiced by many growers to secure early maturity and larger bunches. It consists simply of removing a ring of bark from the bearing arm between the main vine and the buds which are to produce fruit the first season. This does not interfere with the ascent of the sap, but it does prevent the return of the food that has been formed in the leaves. The parts of the branch above the ring can draw upon all the food formed in the leaves of that branch. As a result the overfed bunches grow faster and become larger than they otherwise would.

This matter is fully treated by F. H. Hall, in Bulletin No. 151 of the New York Experiment Station, where results of quite extended experiments are recorded. These experiments tend to show that ringing will mature grapes of some varieties earlier and will also produce larger and more compact bunches. The difference will vary with the variety, season, condition of foliage, amount of fruit allowed to mature on one vine, etc. The quality of finely flavored grapes, however, is liable to be lowered. This may be remedied to some extent by trimming the ringed vines so that but little new growth forms. With careful management the vitality of the vines need not be seriously injured. The whole question of the desirability of ringing and the profit from the process is one which the grower must decide for himself.

\section{FALL PRUNING OF THE VINEYARD.}

Vineyards located where the winters are so mild that the vines need no protection against cold, that they need not be covered in order to save them from destruction, may be pruned either in autumn or spring, at the option or convenience of the owner.

But vineyards in middle and northern Minnesota, where the vines for safety must be put under ground, necessarily must be pruned before such work can be done, as it would be impracticable to remove the vines from the wire trellis and bury the entire season's growth. If the vines were trained to stakes rather than to wire trellises, the vines might be given a preliminary pruning by which the 
vines could be sufficiently shortened to enable them to be readily buried, and then in the spring, when the vine was again tied to the stake, they could be pruned to the proper length.

As to the effect of spring or autumn pruning on the succeeding crop, other things being equal, I believe that pruning in the spring is best. In my experience with a vineyard on the shores of the Hudson during twelve years, where the vines did not require winter protection, $I$ found that pruning in March and early April, rather than in the fall, resulted in the best crop, for the reason that in fall pruning the fruit-buds nearest to the excision of the cane was liable to die for want of moisture or other cause, thus greatly diminishing the number of fruitbearing buds.

The method of double pruning when practicable would require more labor than in complete autumn pruning, but probably the extra labor would be more than paid for in a larger crop.-M. M. Frisselle.

\section{PRUNING GRAPE-VINES.}

Grape-vines may be pruned any time after the leaves drop in the fall until the buds begin to push in the spring. No man can explain to another just how the work should be done, because no established rule can be laid down. A satisfactory knowledge of pruning can only be obtained by experience and a judicious study of nature.

Different varieties require different treatment, and it takes time and study to find out what the requirements are. Nevertheless a few suggestions on the subject might prove helpful to an inquiring subscriber and others.

Beginners are more liable to cause injury by leaving too much wood on their vines than by pruning too closely. Another common mistake is that of leaving the largest canes for fruiting where smaller ones would give better results.

Vines just planted should be cut back to two or three buds; after one year's growth cut back to within about a foot of the ground, more or less, according to growth. Do not allow vines to bear the second year, as it will check their growth and loss will result in the end. An occasional bunch may be left on vigorous vines, but it will pay to pull most of them off when in bloom. Judg. ment should be used again in pruning the second year's growth. The average height of vine when pruned should be about four feet.

The third year they may bear considerable fruit; but in case there are weak vines, these should not be allowed to bear much, which will allow them to catch up with the strong ones, This exemplifies the importance of studying each vine in the vineyard, whether there be one or many varieties, and treating each according to its needs.

In pruning for the fourth year's crop, the lateral branches, which form during the third year's growth, should be cut back to within one or two buds of the main vine, according to circumstances, the latter being cut back to six or seven feet in length. Varieties which have a tendency to overbear should be pruned closer and some of the bunches taken off soon after fruit has set.

This treatment also applies to varieties having weak foliage.

There are various ways of training grapes, but this is simply a matter of taste, and not of so much importance. The trellis system is the cheapest way of supporting vines and makes a much better appearance than the old way of training to stakes. Where a trellis is used the main vines are pruned to resemble in shape 
a $\mathbf{T}$ or, when two wires are used, a double $T$. The main or upright part of vine may remain permanently, but the two or four laterals, as the case may be, should be renewed occasionally. Grapes that are decidedly better than none may be grown with but little care; but if first-class fruit that would sell profitably on the market is desired, the above instructions cannot be too closely observed.Edwin H. Riehl.

\section{THE GRAPE TRELLIS.}

In building a grape trellis, if fence-posts are used, set the end posts so that the strain of the wires will come on the broad side of them; a post set the other way will be pulled out of place in a few years, while set in this way, the posts furnish a greater width of wood to pull against, and they remain solid for many years.

For tightening trellis wires, make the wires fast at one end, and then have as many blocks of wood $8 \times 2 \times 2$ inches as there are wires. Round the blocks a little near the middle, so that the wires will wind around them easily, bore holes through the last post, put the wires through in their proper places, and, instead of fastening them, wind them around the blocks, pulling and winding until they are perfectly tight. Leave the blocks in place, and any time when the wires seem slack, a turn or two of the blocks [with a wrench] will bring them into place again.

The "point" in this figure is the double wire $(a a)$, which prevents the brace from slipping and makes it one with the post; a very useful and valuable device.

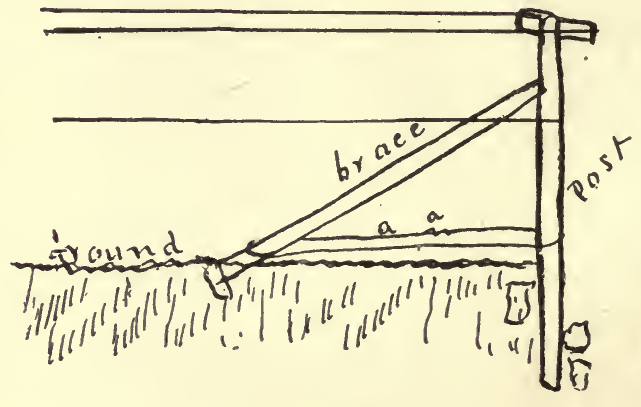

GRAPE ARBORS AND VINES AGAINST THE BUILDINGS.

The grape-vine is so manageable, and, with intelligent training, so beautiful and profitable, that $I$ wonder it is not more used to cover verandas, piazzas, porches, stoops, and outbuildings. Many a spot given up to morning-glories, scarlet runners, cinnamon vines, etc., would grow a fragrant spring bloom, a luxuriant, leafy summer shade, and many pounds of luscious grapes in autumn. Besides, some of the vines, like wistaria, clematis, and honeysuckle, are persistent or perennial, and cling to the trellis during winter, when more light and sunshine are desired on the porch or in the windows, while the grape, trimmed of all superfluous brush in November, waves only "bare poles" (arms or canes) during winter, allowing sun and air free access to the dwelling. We in Kansas little know that a very large proportion of the small, fenced-in back yards of the residence portion of our great cities grow annually tons of fine grapes.

I remember in earliest boyhood that on our street and among our acquaintances it was the rule to have one or more Isabella grape-vines in the back yard. 
These often grew in the midst of a flower border and were trained with long arms, of ten reaching above the windows of the second floor; many of the houses having basements with a front and back sunken and paved area; the vines were planted beyond the cap-stones of the back area about ten or twelve feet from the house; an arbor or slatted trellis carried them straight upward for seven or eight feet then at an angle like a house roof to a point twenty feet above the ground, ending above the windows of the second floor. A long arm was trained to each rafter and each arm had spurs, trimmed to two buds, at regular intervals, and each bud brought two to four bunches of grapes, and the whole was a thing of beauty, shade, and perfume, the hum of insects, and occasional twitter of a wren or other bird, and laden with unnumbered bunches of elegant Isabellas. Others have arched or rectangular arbors or summer-houses, shady with grape leaves, a cool place of rest for the elders and an ideal play-house for the children. Every farmhouse could be beautiful and its interior made more comfortable if grape-vines were planted to clamber on trellis of wire or slats or strings at the porch or stoop, or a foot or two away from the broad side of the house, or on chicken-wire trellis before the sunny windows. Grape-vine shade is of the coolest, as you will find out if you feel under the leaves even on a hot afternoon. Grape-vines are the cheapest of all plants excepting volunteers, as you can get grape wood free when any neighbor is trimming his vines, and you will find instructions for rooting them in this book.

By all means shade the front door, shade the back door, shade the south and west windows of your prairie home, the milk-house, the cave cellar, the cow shed, with grape vines. Put out trees, but the vines will make a cooling shade the second year, while your trees are yet thin of leaf and branch. Any rough poles, chicken wire, barbed wire, smooth wire or even strings will assist and lead the vines to the desired place and form. If you have an out cellar or cave, grapevines planted on either side and trained to clamber over the roof will change the inner temperature in hot weather several degrees, and in all these cases the useful, cooling shade will be succeeded by luscious, healthful fruit. For the above uses, free-growing varieties like Norton's Virginia, Clinton, etc., could be used to advantage, although any ordinary kind will do.

\section{BAGGING GRAPES.}

The following correspondents have bagged grapes, and all but two or three recommend it, some very highly:

Adams, D. M., Rome, Sumner county.

Allison, T. W., Florence, Marion county.

Barnes, J. T., Beloit, Mitchell county.

Baum, G. M., Washington, Washington county.

Dickinson, S. S., Larned, Pawnee county.

Diehl, E. P., Olathe, Johnson county.

Griesa, A. C., Lawrence, Douglas county. Does not advise it.

Moncrief, R. J., Winfield, Cowley county.

Oberndorf, A., jr., Centralia, Nemaha county.

Record, O. M., Thayer, Neosho county.

Sayles, J. H., Norcatur, Decatur county.

Spohr, G. E., Manhattan, Riley county.

Stout, Stephen, Axtell, Marshall county Cloth for bees.

Taylor, C. H., Eskridge, Wabaunsee county. Does not indorse it.

White, D. D., Enon, Barber county. Uses mosquito net.

Holsinger \& Sons, Rosedale, Wyandotte county. 
Every correspondent mentioned in this work was asked if he ever bagged grapes. Many seemed never to have heard of it. Sixteen have practiced it. Some of these do it to a limited extent regularly. Some have tried it, but for want of tact or patience, or owing to press of other duties, thought it did not pay. Some say the rain and wind destroy the paper bags. Some complain of birds and grasshoppers taking most of their grapes. Sacking would save most of these to the grower. The process is easy; girls or women could do it, especially as they are handy with pins and thimble.

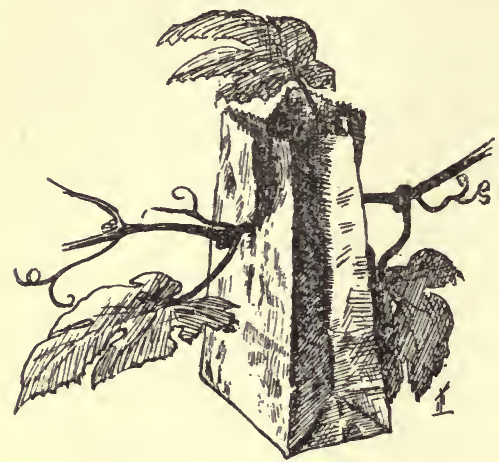

Sack in place.

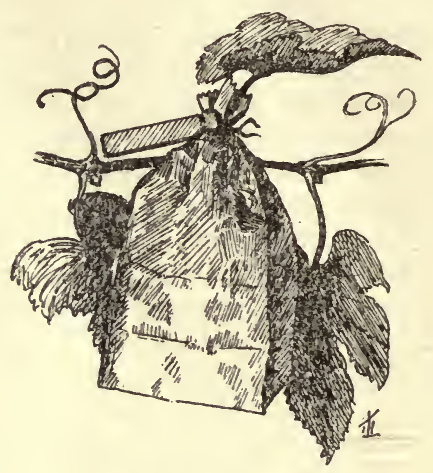

Sack tied or pinned.

Small, strong manila paper sacks, size No. 2, are best. They should be put on when the grapes are the size of bird shot, and should all be on by the time they are one-third grown. Slip the bunch into the open mouth of the sack; fold an inch of the upper end of the sack over the branch above where the bunch is attached; close it in such a way that a common pin (or two) can be thrust through, taking a stitch and leaving the pin there. The pins can be easily thrust through with the aid of a thimble. The bunches are thus protected from birds, grasshoppers and other insects. Spider-webs and dust do not gather in the center of the bunch. Rot and fungous diseases are not so bad, and the sun does not burn them. The bloom stays on the berry, and the bunches are always larger and more perfect. Besides, they may be left on the vines from two to four weeks longer in autumn, thus prolonging the season. They may then be cut, leaving the bags on them, and kept still longer in a cool apartment. This prolongs the season and brings them into a higher market, even if only for family use, thus paying for all the trouble.

\section{OVERBEARING.}

Some vines set more fruit than they can carry to perfection. There can be no hard-and-fast rule. Thrifty vines of vigorous varieties will, in Kansas, set three to five clusters to each shoot. If there are two shoots to each spur and twenty spurs are left, there will be between 100 and 120 clusters of grapes. Now if the soil is not strong, or the grape-vine is crowded by other vines, trees, or crops, it is quite possible that 120 clusters are far too many. If you thin, snip off one bunch from each shoot, which will bring them down to eighty clusters. If the vine is well established and the ground rich, it may mature all of these and do it well. Experience is the best teacher, but leave too few rather than too many. 


\section{SACKING GRAPES.}

By Frank Holsinger, Rosedale.

I do wish you could see the beautiful grapes we are luxuriating on at this time. I sacked 700 bunches for home use, being about one-third of my plant at my home.

Understand, this is in the city limits. We have some seven acres on the farms, away from the influence of the hateful sparrow.

Soon as the grapes commenced coloring myriads of these pests hovered over my grapes, puncturing all that showed color. I had them cut and sold ere ripening. Those in sacks were immune from their ravages, as also from insects.

This is especially true of those that were sacked early, when about the size of No. 2 shot. These little bunches seemed lost in the two-pound sacks, but they swelled out, and are now things of beauty.

I have opened sack after sack without an immature or affected berry, save perchance one that had not fully ripened.

- I will stick to sacking as long as I live. Would all in our cities who cannot get grapes would try it.

\section{DESCRIPTION OF VARIETIES.}

Agaveam (Rogers's No. 15). Bunch large, moderately compact, and shouldered; berry large, nearly round, dark, dull, reddish brown; flesh tender, little pulp, very slightly partaking of the foxy aroma; of good vinous flavor. Season medium, or soon after Concord. Vine a strong grower and great bearer, but the fruit is easily affected by rot. [Self-fertile.] (Thomas.)

Bacchus. Very hard in wood, leaf, and fruit; very productive; bunch compact, about six inches long; berry medium in size, pulp half tender; juicy and sprightly. (Hart Pioneer Nursery.)

Barry (Rogers's No. 43). Raised by E. S. Rogers, of Salem, Mass. Vine vigorous, productive; bunch rather large, short, broad, compact, often shouldered; berry large, roundish, black; flesh tender, nearly free from pulp, juicy, sweet, pleasant. Ripens about the time of Concord. [Self-sterile.] (Downing.)

Berkman's. Bunch medium, compact, very round, dark wine color; flesh juicy, vinous, rich; pulp tender. A cross between Clinton and Delaware. Very good. Ripens September. [Self-fertile.] (Thomas.)

Brighton. Bunch medium or rather large, shouldered, moderately compact; berries full, medium in size, round, dark red or maroon when fully ripe, with a purple bloom; flesh tender, pulp slight, quality very good. Vine a vigorous grower, very productive, rather early, valuable. A cross of the Concord and Diana-Hamburg, and one-fourth exotic. (Thomas.)

Brilliant. Bunch large, conical, shouldered, compact; berry large, round, nearly black; flesh sweet, juicy, rich, vinous; pulp tender. A cross of Delaware upon Findly. Ripens a little earlier than Concord. [Self-fertile.] (Thomas.)

Campbell's Early. This new, extra-early grape is the strongest-growing vine of thirty varieties in my family collection, even ahead of Concord and Niagara. Bunches very large, shouldered, and compact; extra-large black berries with purple bloom. Good, but not highest quality. Season early, and unquestionably the very best early grape in existence. (J. H. Hale.) 
Catawba. Bunches medium in size, shouldered; berries large, deep copper red, becoming purple when fully ripe; flesh slightly pulpy, juicy, sweet, aromatic, rich, slightly musky. Does not ripen well as far north as $43^{\circ}$ latitude, excepting in warm exposures. Very productive. [Self-fertile.] (Thomas.)

Carman (Post-oak Grape No. $1 \times$ Triumph). Growth at Denison, vigorous; at College Station, medium; at Hornsby, Travis county [all Texas], vigorous; at Experiment, Ga., and Knoxville, Tenn., strong, very prolific; wood a little cottony; foliage never mildews; leaves medium to large, three- to fivelobed, little cottony beneath, dark green, margins prominently toothed; clusters large to very large, have reached two pounds in rare instances, shouldered or branched, conical, very compact; berries very persistent, medium, globular, black with a thin bloom, skin thin and tough, never cracking; pulp meaty, firm, yet tender, when fully ripe of pure rich quality, much superior to Concord; seeds one to three, easily leaving the pulp. At Denison, vines thirteen years old that have borne ten heavy crops show no signs of decline, while younger vines at College Station show decline. Soil at Denison, sandy on red-clay subsoil; at College Station, dark gravelly on stiff joint-clay on hard-pan subsoil. There are hundreds of vines in bearing at Denison and four at College Station. It has been one of the most profitable market grapes in the Denison market, ripening one to three weeks after Concord was gone. [Self-fertile.] (Munson.)

Centennial. Bunch and berry medium; light red, tender, rich, vinous. Watertown, N. Y. [Self-fertile.] (Thomas.)

Chandler. Originated with N. M. Chandler, Ottawa, Kan. Himself and A. Willis recommend it. Mr. Willis says: "The Chandler grape is a fruit of much promise, but as far as I know has never been offered to the trade." Statement of Mr. Chandler: "About twelve years ago I had a Worden vine standing alone, about eight rods distant from other varieties. In the spring I noticed a grape seed had germinated near the root, and I took care of it. It grew about eight inches high, and stood unprotected during the next winter. The following spring I set it by itself ; the third year from germination it bore two clusters. I sacked them, and on September 25 gathered them, and was surprised to find them perfect, with large, white berries of excellent quality. I presented them at our fair, and experts pronounced them beautiful, fine, and, in quality, excellent. A few years later the Franklin County Horticultural Society named it the 'Chandler seedling.' I have had it at the fair each year, and am well pleased with its conduct, The vine is of fair growth and hardy; has never shown tenderness from sun or frosts, needing no protection in winter. The clusters are from medium to large, compact, with berries above medium size, and they mature early. It is a free bearer; every year it fruits alike for me." [Self-fertile.]

Champion. Bunches large and compact; berry large, covered with a rich bloom; medium in quality ; vine a strong and healthy grower and a good keeper; profitable for market on account of its earliness. [Self-fertile.] (Sedgwick Nursery Company.)

Clinton. Bunches medium or small, not shouldered, compact; berry nearly round, small, black; bloom thin, blue; pulpy, juicy with a slightly harsh flavor. Very hardy and rather early. Western New York. Requires thorough maturity to develop its flavor. A good keeper. [Self-fertile.] (Thomas.)

Colerain. A white grape of vigorous growth and superior quality; bunches good; berry a clear golden green, very juicy, rich, and sweet. Its main defect for general culture is its very thin, tender skin, which is readily punctured by June- 
bugs and other insects, which quickly make the beautiful berries unsightly and unmarketable. [Self-fertile.] (Bulletin No. 92, Kentucky Agricultural Experiment Station.)

Columbian. Fruit very large, dark red, bordering on purple; plant a very strong, robust grower, hardy and wonderfully productive. (Hart Pioneer Nursery.)

Columbian Imperial. Originated with J. S. McKinley, Morgan, Ohio, 1885. Recommended by the horticultural department of the Ohio Experiment Station. It is supposed to be a labrusca-riparia hybrid. Vine a vigorous grower, with numerous canes; ten to twenty berries in a cluster; very large, one inch in diameter; color brownish black; thin bloom; skin thick and tough, pulp firm; flavor fair. A good bearer and a valuable market grape.

Concord. Bunches compact, large, shouldered; berries large, round, almost black, covered with bloom; skin very tender; flesh juicy, buttery, sweet. Ripens ten days before the Isabella; is healthy, vigorous, and very productive. The extreme hardiness, vigor and productiveness of the vine, and the large size and fine apppearance of the bunches and berries, have rendered the Concord one of the most popular market sorts, although inferior to several others in flavor. It succeeds well throughout the entire West. The fruit is too tender for shipping long distances. [See frontispiece.] [Self-fertile.] (Thomas.)

Cottage. Bunch small, sometimes shouldered; berry large, round, black; pulp tough, sweet, somewhat foxy. (Thomas.)

Croton. Bunch medium in size, not very compact, shouldered; berries varying from small to medium, light greenish yellow; skin thin; flesh juicy, sweet, with an excellent, pleasant flavor. Ripens early. A cross of the Delaware and the Chasselas. Liable to mildew in some localities. [Self-fertile.] (Thomas.)

Cynthiana. Bunch moderately compact, shouldered; berries small, round, black. Resembling Norton's Virginia, but better. Southwest. (Thomas.)

Delaware. Bunches small, compact, generally shouldered; berries smallish, round; skin thin, light red, translucent; exceedingly sweet, aromatic. Earls. A vigorous grower under high culture; requires a strong, rich soil. An early and profuse bearer. Hardy. Delaware, Ohio. One of the most excellent and popular of all American grapes, especially at the North and East. Often injured by overbearing. [Self-fertile.] (Thomas.)

Diana. A seedling from the Catawba, which it resembles, but paler, or a pale, grayish red. Bunches compact; berries round, almost without pulp, juicy, sweet, rich. It ripens best on poor soil. Origin, Milton, Mass. [Self-fertile.] (Thomas.)

- Dracut Amber. A brown fox, somewhat resembling, but not equal in flavor to, the Northern Muscadine. [Nearly self-fertile.] (Thomas.)

Duchess. Bunch medium, sometimes large, shouldered; berries moderate in size, light green, tinged with pale yellow and amber; tender, free from pulp, sweet, rich, and excellent in quality. One-fourth exotic. Season medium. Ulster county, New York. [Self-fertile.] (Thomas.)

Early Ohio. A new black grape. Its points of merit are extreme earliness, hardiness, productiveness, and being of better quality than most early sorts. Berries large, firm, of spicy, pleasant flavor; hangs to the stem with a persistency that makes its shipping qualities of the highest order. Ripens about three weeks before the Concord. Promises to be valuable as an early sort, and also desirable for garden culture. [Self fertile.] (Michigan Nurseries.) 
Early Victor. In bunch the berry is rather below the average, but ripens very early; is very pure in flavor, with very little pulp; is exceedingly sweet, sprightly, and vinous; never cracks, and adheres firmly to the bunch. [Selffertile.] (Sedgwick Nursery Company.)

Eaton. Bunch large, shouldered; berry large, round, black, blue bloom; juicy, tender. Uncertain ripener in some localities. Seedling of Concord. [Selfsterile.] (Thomas.)

Eclipse. Bunch large, double shouldered, not very compact; berry very large, tender, rich, sweet, sprightly, vinous, and of excellent quality; vine hardy, healthy, very vigorous and productive. (Sedgwick Nursery Company.)

Eldorado. Vine strong, only moderately productive; bunches loose and quite susceptible to insect attacks and rot; berry of medium size, golden green; pulp sweet, tender, and of excellent quality. Ripe last week in August. [Selfsterile.] (Bulletin No. 92, Kentucky Agricultural Experiment Station.)

Elviru. Bunch medium; berry medium, round, pale green, tender, sweet; hangs well to the vines and is improved by slight frost. Missouri. [Self-fertile.] (Thomas.)

Empire State. Bunch rather large, shouldered; berry medium, yellowish white, rich, sweet, sprightly, very good. Early. A cross of Hartford and Clinton. Newburg, N. Y. A promising new sort. [Self-fertile.] (Thomas.)

Eumelan. A chance seedling, originated at Fishkill, N. Y. Vine hardy, productive, and ripens early; bunch of good size, compact, shouldered; berry medium size, nearly round, of a deep purple or bluish black color, covered with a light bloom; flesh tender, melting, ripening to the center, sweet, sprightly, vinous. [Nearly self-sterile.] (Downing.)

Geneva. A good grower and fairly productive. It has beautiful white berries, of good size; skin tender, very sweet, and one of the best half-dozen in quality. Its chief fault upon our grounds is that, on account of its tender skin and pulp, it is almost ruined by June-bugs, wasps, and bees, which swarm upon the beautiful fruit. [Nearly self-sterile.] (Bulletin No. 92, Kentucky Agricultural Experiment Station.)

Green's Golden. Bunch medium, long stem, compact, regular; berry large, round, greenish white, very juicy, acid; a handsome grape; poor shipper. [Self-sterile.] (Thomas.)

Green Mountain (Winchell). Bunch small, compact, sometimes shouldered; berry medium, oval, greenish white; thin bloom; pulp tender, juicy, very sweet and rich; free from rot and mildew. The berries hang well to the stem. An excellent grape, with a future. (Thomas.)

Goethe (Rogers's No. 1). Bunch rather large, moderately compact, shouldered; berry quite large, oval, yellowish green, often more or less blotched or shaded dull red; flesh tender, with no pulp, sweet, slightly aromatic, and, when well ripened, of excellent quality; rather late, occasionally ripening well at the North, better at the South; vine vigorous and productive. This has more of the exotic character than any other of Rogers's hybrids, and, therefore, less reliable, and more subject to mildew. (Thomas.)

Hartford Prolific. Bunches large, shouldered, rather compact; berries rather large, round; skin thick, black, with a bloom; flesh sweet, rather juicy, with some toughness and acidity in its pulp; ripens one week before the Concord. Hardy, vigorous, productive. Valued for its earliness and easy culture. [Self-fertile.] (Thomas.) 
Hayes. Bunch medium, cylindrical, shouldered; berry below medium size, round, yellowish white; pulp rich, juicy, vinous. [Nearly self-sterile.] (Thomas.)

Herbert (Rogers's No. 44). Berry medium, sweet, a little pulpy; bunch rather loose; moderately productive. Blooms early. Ripens with Concord. [Self-sterile.] (Thomas.)

Herbemont (Warren Neal). Bunches large, compact, shouldered; berries small, round, dark blue or violet, with a thick, light bloom; skin thin; pulp none, with a sweet, rich, vinous, aromatic juice. Vigorous grower. Tender at the north. Succeeds well as far north as Cincinnati. (Thomas.)

Herman Jaeger (Post Oak No. $1 \times$ Herbemont). Growth very strong, wood a little downy; grows from cuttings fairly well; endures the Texas climate well and succeeds well at College Station; leaves large, deeply three- to fivelobed, little cottony on under side; bunches large to very large, shouldered, conical, very compact, peduncle short; berries small to medium, black, persistent; skin thin, tough, does not crack; pulp tender, very juicy, easily freeing the one to three medium seeds; quality better than Concord. A profitable market grape; prolific; ripens about a week later than Concord. Not attacked to any extent by mildew, rot, or leaf-folder. (Munson.)

Hicks (Irl R. Hicks). New, very hardy and healthy, of strongest growth, large in bunch and berry, wonderfully productive, and of the finest quality; superior to all native grapes. Destined to be the great Concord of the twentieth century. Propagated and described by Henry Wallis, Wellston, Mo.

Ideal. This fine, red grape is one of Mr. Burr's seedlings of Delaware, and is as large in bunch and berry as Concord, and is better in quality than Delaware; good grower, hardy, healthy, and very productive; rots and mildews in some localities; this is no doubt the finest red grape, of large size, and wherever it can be successfully grown is very desirable. (Sedgwick Nursery Company.)

Iona. Bunches large, shouldered, not compact; berries medium, round, pale red, becoming dark red at maturity; flesh tender, with little pulp, and with a rich, slightly vinous, excellent flavor. Peekskill, N. Y. Fails in most localities, and often much injured by overbearing. [Self-fertile.] (Thomas.)

Ives. Bunch medium, compact, shouldered; berry rather small, roundish oval, black, with some pulp; of moderate quality. Origin, Cincinnati. Season medium or rather late. (Thomas.)

Janesville. An early, black grape, of moderate size, ripening with Hartford; of rather poor quality. Western. Valuable only in cold regions. [Selffertile.] (Thomas.)

Jefferson. Bunch rather large, shouldered, compact; berry full, medium in size, roundish oval, light red, quality excellent; vine healthy and vigorous, and very productive. Season medium. Raised by J. H. Ricketts, Newburg, N. Y. [Self-fertile.] (Thomas.)

Jessica. A small, early, white grape, a rather weak grower; cluster small; berry sweet and good. Of no decided merit. [Self-fertile.] (Bulletin No. 92, Kentucky Agricultural Experiment Station.)

Jewel. Seedling of Delaware; the earliest and best grape of high quality, fully tested; bunch medium, shouldered, compact; berry medium, skin rather tough, slightly pulpy, sweet, rich, sprightly, vinous, of the best quality; vine not vigorous until fully established; free from rot and mildew; will hang on the vine long after ripe, and ships well. [Self-sterile.] (Thomas.) 
Lady. Berry and bunch medium, light greenish yellow, tender, sweet; early; hardy. Ohio. [Self-fertile.] (Thomas.)

Lady Washington (Ricketts). Fruit yellow, tinged with pink; bunches very large, often weighing a pound; vine strong, very hardy. (Sedgwick Nursery Company.)

Lindley (Rogers's No. 9). Bunch medium in size, rather long and compact; berry medium, nearly round, reddish, sweet, slightly aromatic, very good when full grown. Rather early. Vine vigorous and productive. [Self-sterile.] (Thomas.)

Logan. Bunches medium, shouldered, compact; berries rather large, oval, black; flesh juicy, with little pulp, and of a moderate flavor. Vine a slender grower; leaves small, three-lobed. Early. (Thomas.)

Martha. Bunches medium, rather loose, shouldered; berries large, round, pale yellow; slightly pulpy, sweet, juicy, a little foxy. Vine a hardy, healthy and strong grower. A seedling of Concord. (Org. Sam'l Miller, Missouri.)

Massasoit (Rogers's No. 3). Bunch medium, rather loose; berry rather large, roundish, light red, sweet, good. Early - a little before Concord. Vine moderately vigorous. [Self-sterile.] (Thomas.)

McPike. Very large, black; skin thin, juicy, sweet; resembles Eaton. (Thomas.)

Merrimac (Rogers's No. 19). Bunch medium, rather short; berry large, round, black; flesh tender, sweet, of good quality. Quite early. [Self-sterile.] (Thomas.)

Mills. Bunch large, long, shouldered; berry large, round, black; thin skin; flesh juicy, rich, vinous. [Self-fertile.] (Thomas.)

Missouri Reisling (Reisling). A very hardy and healthy grower; bunch and berry medium, compact, pale yellow, changing to amber when very ripe; sweet, juicy, vinous, very tender pulp; quality best for table. (Sedgwick Nursery Company.)

Moore's Diamond. Originated by Jacob Moore, the producer of the Brighton, and seems destined to become very popular. Equal in size to Concord; color greenish white, with rich yellow tinge when fully ripe; flesh tender, juicy, nearly transparent, and very good; vine vigorous, hardy, and productive. Ripens two weeks before Concord. [Self-fertile.] (Michigan Nurseries.)

Moore's Early. Bunch medium; berry large, black, good. Valuable for its earliness. Massachusetts. [Self-fertile.] (Thomas.)

Moyer. Vines small, weak; clusters small, loose; berries small, round, reddish; pulp tender, juicy, soft, quality poor. Not productive. Season last of July. A grape of very little value.

Viagara. Bunch rather large, slightly shouldered; berry nearly round, pale green, becoming partly yellow; medium in quality. Vine possessing great rigor and productiveness. A cross of Concord and Cassady. Lockport, N. Y. [Self-fertile.] (Thomas.)

Noale. Bunch medium, compact, shouldered; berry medium, round, pale yellow; pulp hard, sweet, of moderate quality. Illinois. [Self-sterile.] (Thomas.)

Northern Muscadine. Bunches small, short, compact; berries medium, round, brownish red; skin thick, with the character and odor of the brown fox grape. The berries fall from the bunches as soon as ripe, which is about one week before Concord. New Lebanon, Columbia county, New York. Valuable only for its earliness and extreme hardiness. [Self-sterile.] (Thomas.) 
Norton's Virginia. Bunches long, moderately compact; berries small, round; skin thin, dark purple; pulpy, vinous, somewhat harsh, rather pleasant, and rich. Shoots strong, hardy. (Thomas.)

Osage. Bunch large, shouldered; berry large, round, black, blue bloom; flesh juicy, sweet, foxy. (Thomas.)

Ozark. Bunch large, compact, shouldered; berry medium, round, black, blue bloom. (Thomas.)

Paragon. Bunch large, shouldered, compact, handsome; berry large, tender, sweet, rich, sprightly, vinous, without pulp; a bag of delicious fruit; hardy, healthy, vigorous, and productive; free from rot or mildew; ripe with Concord, but hangs well; valuable table and market grape. [Self-fertile.] (Sedgwick Nursery Company.)

Perkins. Bunch rather small, conical, shouldered; berry round, amber, whitish bloom. A brown fox grape, resembling Northern Muscadine, but lighter colored and inferior in quality. [Self-fertile.] (Thomas.)

Peter Wylie. Bunch small; berry small, red. Little value. (Thomas.)

Pocklington. Bunch medium, shouldered, compact; berry large, pale greenish yellow, pulpy, with good flavor when fully ripe. Season rather late. Vine hardy, healthy, productive. A showy and attractive grape. A seedling of Concord. Origin, Sandy Hill, N. Y. [Self-fertile.] (Thomas.)

Poughkeepsie. Red. A cross between Delaware and Iona, of high quality and very handsome; larger than Delaware. [Self-fertile.] (Hart Pioneer Nurseries.)

Prentiss. Bunch medium, sometimes shouldered, compact; berry medium, roundish oval, greenish white, becoming tinged with pale yellow, sweet, and very good in quality. Slow grower. Season medium. A seedling of the Isabella. Steuben county, New York. [Self-fertile.] (Thomas.)

Rochester. Of the same type as the Delaware. A weak grower. [Selfsterile.] (Bulletin No. 92, Kentucky Agricultural Experiment Station.)

Rommel (Elvira $\times$ Triumph). Growth medium, shoots smooth, short jointed, tapering rapidly; requires short pruning; prolific; endures the climate [Texas] better than the Concord; leaves medium, shallow, three-lobed, smooth above, a little felted below, teeth prominent, irregular; attacked by mildew in wet, sultry weather, but less than Delaware; always holds on until crop matures; clusters medium to small, ovate or cylindrical, often shouldered, compact, peduncle short; berries large, globular, persistent, greenish white when fully ripe; skin very thin and delicate, but rarely cracks on vine; too tender for long shipment; carries well 50 to 100 miles in five-pound baskets; pulp melting and perfectly delicious when fully ripenened, or if weather is wet and cloudy at ripening time. Several hundred vines have always been very profitable in local market. Ripe just before Concord. Fruit rarely attacked by rot. [Self-fertile.] (Munson.)

Salem (Rogers's No. 22). Bunch large, short, rather compact; berry large, round, dark, full red, tender, nearly free from pulp, of a moderate but very agreeable flavor; season medium; vine vigorous and productive. Succeeds in many localities, mildews in others. (Thomas.)

Schuylkill Muscadel (Cape Grape, Spring Hill Constantia). Bunches not. shouldered, compact; berries medium, nearly round, slightly oval; skin thick, black; pulp firm, coarse, acid until fully ripe; season late. Worthless in New. England and New York; good farther south. A native of Pennsylvania. (Thomas.) 
Taylor's Bullitt. Bunches medium, loose, with many imperfect berries; berries rather small, greenish white, of moderate quality. A strong grower. Kentucky. (Thomas.)

Telegraph. Bunch above medium, compact; berry rather large, round, black, juicy, with some pulp, of moderate quality; valuable for its earliness (ripening about the same time as Hartford). Vine hardy, vigorous. Origin near Philadelphia. [Self-fertile.] (Thomas.)

Utster Prolific. Bunch small; berry small, round, bright red, good; vine weak grower. [Self-fertile.] (Thomas.)

Vergennes. Cluster and berry full medium; light amber; quality good; early. Vermont. A good keeper. [Nearly self-sterile.] (Thomas.)

Victoria. This grape has many synonyms. The Victoria has long been considered the first of black grapes for the vinery, but it will very rarely perfect its fruit out-of-doors. Its very large size and luscious flavor render it universally esteemed. Bunches large (about nine inches deep), and mostly with two shoulders, making it broad at the top. Berries very large, roundish, slightly inclining to oval. Skin rather thick, deep, brownish purple, becoming nearly black at full maturity ; flavor very sugary and rich; a good and regular bearer. [Self-fertile.] (Downing.)

Wilder (Rogers's No. 4). Raised by E. S. Rogers, Salem, Mass. Vine vigorous, very productive. This is one of the best of Rogers's seedlings; adheres well. The bunch keeps well after it is gathered, and is a promising variety for market. Bunch large, compact, shouldered, sometimes double-shouldered; berry large, round, black, slight bloom; flesh tender nearly to the center, juicy, sweet, rich, slightly aromatic; ripens about the time of Concord. [Self-sterile.] (Downing.)

Woodmuff Red. Bunch large, shouldered; berry large, red. [Self-sterile.] (Thomas.)

Worden. Resembles Concord, but rather larger; superior in quality, and ten days earlier; valuable. [Self-fertile.] (Thomas.)

Wyoming Red. Medium early, vigorous, and hardy; quality moderate. [Self-sterile.] (Thomas.)

\section{A NEW RED GRAPE.}

From Orange Judd Farmer.

Among the many new grapes exhibited at the last fair of the American Institute, in New York, none has interested us more than the Charlton. It is a crose between the Brighton and Mills, raised by John Charlton, Rochester, N. Y. The original vine has fruited the last six years and its fruit seems to improve each season. The berries are globular in shape, and medium to large in size, moderately compact, and sometimes shouldered; color red, similar to Catawba; quality best, flesh tender and melting, juicy, sweet, and vinous, separating readily from the seeds, of which there are but few. Skin thin, but firm enough to insure good keeping and shipping quality. Season early, showing color before Concord, which is so popular in Michigan and our Western states generally, but the fruit is in eating condition before it is fully colored. The vine is a strong and healthy one and healthy grower and a prolific bearer. The Charlton grape is not offered for sale yet, and we shall watch its development with no little interest. 


\section{VOTED LIST.}

At the thirtieth annual meeting of the Kansas State Horticultural Society, a vote on varieties of grapes for Kansas was taken, as follows: Concord, 30; Worden, 23; Moore's Early, 15; Niagara, 8; Catawba, 5; Pocklington and Goethe, 4 each; Moore's Diamond, Delaware, and Dracut Amber, 3 each; Agawam, Telegraph, Elvira, and Champion, 2 each; Supreme, Early Victor, Osage, Paragon, Primate, Magnate, White Beauty, Cynthiana, Ozark, Brighton, Wyoming Red, Ives, Lady, Lady Washington, F. B. Hayes, Green Mountain, Martha Washington, Salem, Prentiss, and Early Ohio, 1 each. This has little significance excepting on first three to five varieties, but it shows what was being tried by the members present.

\section{PREPARATION OF GRAPE JUICE.}

Each year, as the grape season approaches, we are asked how to put up grape juice for family use. Several readers have given their methods, but it seems well to repeat former instructions. In proceeding, use only clean, well-ripened grapes. I prefer expressing the juice in an ordinary hand mill (same as making cider), by grinding the grapes. The advantage is you get the juice at once, and that which is expressed by grinding is clear and retains so little foreign matter or pomace. It may, by careful straining through double-thickness light flannel, be immediately bottled, while that obtained from pressing the skins, pulp, seeds, etc., will require, besides straining, a little time to precipitate a sediment resulting from pressing. I sometimes filter through a few inches of clean, washed river or creek sand. The sooner, however, it can be bottled and corked the less fermentation and the more of the peculiar grape aroma may be retained; whereas, if the grapes are crushed in a tub or barrel, I find it difficult or impossible to $\theta x$ press the juice until fermentation dissolves the pulp, thereby losing much of the grape flavor; but the fermentation cuts no figure in the keeping qualities, as I sometimes, for variety, let some ferment to a certain flavor, when I heat and seal it, with the assurance that when opened, in the months or years following, the same flavor will prevail. I use the ordinary wine and beer bottles. Carefully wash and drain them; fill to within about three inches of the top; set in ordinary wash-boiler on the stove; put an inch of sand on the bottom, or fit a thin board over the bottom, to prevent the bottom of bottles overheating, to break, or to give the juice a cooked flavor; fill the boiler with bottles as close as they will stand without crowding, and fill the boiler with cold water to within about four inches of the top of the bottles. Lay on the lid and start the fire. Bring the water slowly to a distinct simmer, but in no instance allow it to come to a boil, as this, too, will cook the juice. Have your corks steaming; put them into a onequart fruit can filled half full of hot water, and lay on the cap; set within the boiler to heat and steam while bottles are heating.-Green's Fruit Grower.

\section{GRAPES - ORDER OF RIPENING.}

In Bulletin No.46, from the Missouri Experiment Station, Prof. J. C. Whitten gives a list of grapes fruited in 1898, arranged in the order of ripening.

In noting the comparative date of ripening of the different varieties of grapes, it should be borne in mind that they differ in this respect in different 


\title{
EXTRACTS FROM A BULLETIN ON GRAPE CULTURE ISSUED BY THE MISSOURI EXPERIMENT STATION.
}

\author{
By Prof. J. C. Whitten.
}

For several years a number of varieties of grapes have been grown on the horticultural grounds. Others have been planted from time to time during the past ten years. In the spring of 1894 a vineyard of 130 varieties was planted, comprising all the more prominent varieties in the older vineyards and many newer sorts then coming into prominence. This planting has been enlarged each season since, until it now contains about 150 kinds. The present bulletin deals mainly with the grapes planted in 1894, they having just completed their fifth season's growth and their third or fourth season's fruiting. This has enabled us to compare vines of the same age. The following is a summary of the results of these studies:

1. The following varieties ripened in 1898 ahead of Moore's Early: Early Ohio, Champion, Green Mountain, Moyer, Hartford, Jewel, Ives, Janesville, New Haven, Aminia, and Brighton.

2. Among the best very early varieties for commercial planting, judging from our own experience and the experience of practical growers, are: Green Mountain, Campbell's Early, Jewel, New Haven, Aminia, Brighton, Moore's Early, and Norfolk.

3. The grapes having the largest berry are: Columbian Imperial, McPike, Eaton, Salem, and Moore's Early.

4. The Ozark is the most vigorous and productive variety we have tested.

5. Among the most promising comparatively new or little known varieties are: America, Aminia, Brilliant, Campbell's Early, Green Mountain, Hicks, McPike, New Haven, Norfolk, Ozark, Rochester, and Rommel.

6. In our opinion, more attention might profitably be given to growing and working up a demand for fine table grapes; especially the earlier varieties. The demand for grapes of the best quality increases as the consumers become acquainted with their merits and acquire a taste for them.

7. It pays to sack fine table grapes of most varieties, as it adds to their appearance and keeping qualities, thus increasing their value and insuring ready sale at good prices. Those that are capable of self-fertilization should be sacked while in blossom or before; those incapable of self-fertilization should be sacked as soon as the fruit has set.

8. Those varieties which have descended from our native astivalis grape, or from the closely related post oak grape, are more healthy, vigorous and drought resisting and hold their fruit longer than other classes of grapes in this section. They are also more prolific, if we count simply the number of berries set, regardless of size. In some varieties of this class the berries attain very large size without diminishing the number of berries in the cluster. Ozark is an example.

9. Varieties of the labrusca class have the largest and handsomest fruit, and produce most in quantity, though not in number of grapes. They sometimes suffer from the heat of summer.

10. The hybrid varieties between the American and European grapes average highest in quality, though they lack the vigor, health and drought-resisting capacity of our native grapes.

11. About sixty per cent. of the varieties tested are capable of perfect selffertilization; that is, they will set fruit without the aid of pollen from other va- 
rieties. The remaining forty per cent. are not fruitful unless pollenized by other sorts, and should be planted adjacent to strong pollen-bearing sorts that flower at the same time.

12. Where the above-mentioned self-sterile varieties are pollenized by other sorts, the variety furnishing the pollen apparently has nothing to do with determining the quality of the fruit thus produced.

About 150 varieties were reported upon as to vigor, health of vine, color and quality of fruit, date of blooming and ripening, etc. The time of ripening of the various sorts extended from August 7, when the Early Ohio, a grape of very poor quality, ripened, to September 20, when the Cunningham was ready for market. Champion, another poor grape, ripened August 9, and Green Mountain, a white grape of good quality, ripened August 10. Moore's Early, the standard early market grape, ripened August 13. The bulletin, under the head of "Varieties to Plant," has comments on the vigor and health of the vines of the varieties tested, with notes on the quality of fruit.

The varieties most largely grown for profit in this state, by those who depend upon shipping to supply the ordinary demand, are Moore's Early, Worden, and Concord. These standard sorts have been found to succeed well on the station grounds.

The following ripened ahead of Moore's Early, and are found to succeed well here: Early Ohio, Champion, Hartford, Green Mountain, Jewel and Aminia, maturing in the order named.

The best table grapes, combining fine quality with at least a fair vigor and productiveness, are: Green Mountain, New Haven, Aminia, Brighton, Moore's Early, Norfolk, Massasoit, Ideal, Diamond, Barry, Rommel, Woodruff Red (finer in appearance than in quality), Lindley, Challenge, Norton, Rochester, Jefferson, Agawam, Poughkeepsie Red, Brilliant and Berckman's, ripening in the order named.

Sacking grapes just after the fruit is fairly set, when grapes are about as large as pin heads, improves the quality of some varieties, protects the fruit from rot and insects, and makes the skin of the berry more tender. Self-fertile varieties may be sacked before the bloom opens, and the Green Mountain improved wonderfully in quality when so treated. Although an early variety, where the Green Mountain was sacked before the bloom opened, the fruit remained on clusters till late in September.

Concluding the subject of varieties, the bulletin says:

We have a large number of good varieties of American grapes. Different varieties are adapted to different purposes, as well as to different soils, localities, and conditions. The Bushberg (Mo.) catalogue describes 500 varieties, from which scores of kinds may be selected, any one of which may be better suited to some given purpose than is even the cosmopolitan Concord or any other grape. Every year new varieties appear. Very rapid strides are now being made in the way of adapting these varieties to special purposes. The above facts are well known to every grape grower. It is time the public should discover that there are now many American varieties about equal in quality to the best European or California grapes. Why should Missouri [or Kansas] continue to pay ten or twenty cents per pound for California grapes when our home-grown product sells for two or three cents a pound? In Aminia, Brighton, Lindley, Brilliant, Goethe, and many other sorts, we have varieties that are certainly as good as the California product, picked green and shipped half way across the cuntinent.

The present rapid introduction of new varieties adapted to special purposes extends the grape season over a longer period, and adapts the grape to a greater 
number of special purposes. The improvement in the quality of certain kinds renders the grape a more desirable dessert fruit. These facts increase the possibilities of a much larger consumption of the grape than now exists.

Some men make money by growing superior varieties and labeling them "Concord." The name suits the people; the improvement in quality suits them better. Once they buy such grapes they become anxious to secure this brand of "Concords" even at an advanced price.

Why not grow more of the best grapes; label them true to name; educate the consumers to an honest appreciation of the merits of each variety, as well as to the special purpose for which it is adapted, and thus increase the demand for a larger grape product? There are people in any market who want to buy good grapes, once they become acquainted with them. Goethe has sold here for eight cents per pound, to the few people who know its quality, when ordinary grapes were a drug in the market at two cents a pound.

A sloping location with eastern or southern exposure is preferred; most growers practice summer pruning; all use wire trellis for support of vines; rows should run north and south; about $8 \times 9$ or $8 \times 10$ feet seems to be the popular distance; all give clean but shallow cultivation, ceasing cultivation in midsummer to allow wood to ripen; spraying with Bordeaux mixture prevents rot. 


\section{REPORTS FROM GRAPE GROWERS.}

L. Perrenoud, Humboldt, Allen county: I have about 800 grape-vines, set $8 \times 8$ feet when two years old. Prune in February or March. My trellis has three wires. I mulched once a few years ago, but it caused the roots to run on top of the ground. Have tried Concord, which is the best, Elvira, and Virginia seedling; have discarded Goethe, Triumph, and Prentiss. Sell them in town for from two to three cents a pound. I have a good crop every year, even when my neighbors have a failure. I do n't give them any better culture than they do, but I prune severely, and always have strong, new wood.

L. D. Buck, Moran, Allen county: I have 200 grape-vines, 100 planted on bottom and 100 on upland. Set two-year-old vines, $8 \times 8$ feet. Prune in February and June. Also prune during summer. My trellis is hedge posts and two wires. Cultivate shallow; I think the scraper and diamond plow the best tools for this work. I have mulched, but do not now. Have tried Concord, Pocklington, Martha, Moore's, and Brighton. Have discarded Clinton; they are too small and sour. Would recommend Concord and Pocklington, as they do best here. Gather the fruit in baskets and market in Iola, receiving from three to five cents per pound. They are a paying crop. I would advise planting extensively if you are near market. Have sacked the fruit, but it does not pay; it would if you had a market, but if you have to ship and sell through an agent, it does not.

E. T. MEtCale, Colony, Anderson county: I have one-half acre of grape-vines, planted on the south slope of a good knoll, but do not know that slope makes any difference. Plant two-year-old vines, six feet apart. Prune in February to two or three buds. Have a trellis made of smooth wire. Cultivate with a spading fork, which I consider the best tool for this work. I mulch sometimes; think they do better. Have tried Rogers's No. 1, Concord, Martha, Niagara, Pocklington, Moore's Diamond, and Agawam. Have discarded none so far; I would recommend the Concord, as it does best here. We consume all the fruit at home. I would not advise planting extensively here unless they can be mulched. Have never sacked the fruit. My wife has put up unfermented grape juice, but I know nothing about it.

William Newcomb, Welda, Anderson county: I have sixty grape-vines, set in red limestone soil; I prefer high land. Set one- or two-year-old vines, twelve feet in the row: Prune closely during February, cutting back to two eyes to the spur; also believe in summer pinching. My trellis is made of Osage orange posts, with three galvanized wires; the top one is four feet from the ground. Cultivate shallow; a five-shovel-cultivator and harrow are best for this work. Never mulch in the spring, but sometimes during summer. Concord is the standard variety here. Have tried and discarded Clinton and Martha; they make a wonderful growth year, after year, but always commence to rot when two-thirds grown, and by fall there is little or no fruit. Persistent spraying will save them and make a fine crop, but at the prices we receive for them in our local market - from three-fourths to one and one-half cents-they will not pay for the labor and expense. The Concord and Worden do best here. I would not advise extensive planting. Have 
bagged some of the fruit and it was all right, but will not pay at the prevailing prices. Grapes are a paying crop for family use, as you can get them fresh from the vines as needed, which is better than buying them, although "dirt cheap."

Ebert Simon, Welda, Anderson county: I have 200 grape-vines, planted on level land; they are Moore's Early and Concord. Set them eight feet apart; mulch with prairie hay; prune in March to two buds. My trellis is of wire. I do not summer prune, as I do n't have time. They are a paying crop.

Francis Schletzbaum, Eden, Atchison county: .I have one acre of grapes, planted on yellow clay, having a southeast slope. Have tried and discarded Catawba, Delaware, Goethe, Pocklington, Lady Washington, Missouri Reisling, and Prentis, on account of mildew, leaf-blight, and rot; would recommend Ives, Concord, Norton's Virginia, and Martha. I planted Ives and Norton's Virginia, $.7 \times 7$ feet. I prune in the fall and at any time, when not frozen, before March 15. My trellis is made of three No. 9 wires, the top one being four and one-half feet from the ground. Have summer pruned, but find it of no advantage; those summer pruned were no better than where not pruned; have never bagged any; gather in twenty-pound baskets. Market in Atchison; realized last year about forty dollars per acre. Some years they are profitable, but they were not this year, as about sixty per cent. of Concord had black rot; Ives was all right.

W. H. Tucker, Effingham, Atchison county : I have eight varieties of grapes, planted on one acre of level land ; have discarded five varieties because they winter-kill; would recommend Concord, Moore's Early, and Worden. I prefer one. year-old vines, set $8 \times 4$ feet; tilled with a one-horse Planet Jr. cultivator and a hoe. Prune any time after the leaves drop until April; summer prune but little. I think three wires, on posts fourteen feet apart, the best trellis. Have never tried bagging grapes. Cut the bunches with a knife or grape shears, and pack in ten- to twenty-pound baskets. Market at or near home; receiving from $\$ 50$ to $\$ 150$ per acre; they are profitable. We put up unfermented grape juice with sugar, for family use only.

J.S. Gaylord, Muscotah, Atchison county: We have about 100 grapes in the orchard, but they are not properly cared for, and in the way; will dig them up soon. Expect to put out about an acre in proper shape.

A. S. Huff, Enon, Barber county: I have one and one-half acres of grapes, planted on sandy loam, which slopes slightly to the east (which I believe is best); my varieties are Concord, Moore's Early, California White, and Moore's Diamond. Concord and California White are my choice; I would recommend Concord as best for Kansas. I prefer one-year-old vines, set eight by ten feet, cultivated with a one-horse stirring plow; prune in February, so they will not bleed. My trellis is made of three No. 9 wires. I summer prune, so the grapes will ripen in proper season. Have never bagged my grapes, and do not advise it; it inclines the sun to burn them ripe, but it would keep the birds off, although they are not bad here. Cut my grapes with a knife into half-bushel baskets, and market in Oklahoma, receiving two and a half to three cents per pound for them. I consider them a big paying crop here. We can grapes for our home use. I think we realize from $\$ 275$ to $\$ 300$ per acre. If I had ten acres of grapes I could find market for them, and would not want anything better to make all the money I should need, because they are a sure crop every year; if late frosts kill the young grapes in bloom, by pruning your vines again they will bloom a second time and mature a crop. 
D. D. White, Enon, Barber county: Have 200 vines growing on level, sandy loam. They are Concord, Delaware, Catawba, and several other varieties that I do not know the names of; Concord is the most prolific. Plant two-year old vines, eight feet each way; cultivate any way to keep perfectly clean. Prune in February and March; also summer prune, so that the strength that would go into the vine growth is put into the fruit. My trellis is made of wires, the top one being six feet from the ground. Have not bagged grapes, but have covered them with mosquito-netting. Gather in baskets; sell at Sharon and Attica. They are not a paying crop for shipping to compete with California. Have put up unfermented grape juice, as follows: One teacup of sugar to one quart of juice; boil, and bottle while hot.

John Piмm, Enon, Barber county: I have one acre of grape-vines, planted on level sandy and red-clay soil. I have Brighton, Concord, Diamond, Moore's Early, Niagara, and Worden. Have tried and discarded Delaware. Have not tried any varieties experimentally. I prefer one-year-old vines, planted eight feet, in rows twelve feet apart. Use a two-horse cultivator; prune in early spring; do a little pruning in the summer, so as to give more strength to the fruit. My trellis is of posts set twelve feet apart, having two wires. Have never bagged grapes, but think it is a good plan, as it protects them from the birds. Market the fruit at home. I consider them a valuable crop. Have put up unfermented grape juice. I have not had much experience with grapes, but am well satisfied with the fruit, and everybody that I know that has given them a fair trial in Barber county finds them a success. They will grow here in spite of drawbacks. They grow wild in abundance; wherever w.e find native timber we find the grape. I am going to increase my acreage each year, as diseases have not bothered much yet. There is a louse or flea that eats the leaves. Concord seems to take the lead, followed by Brighton, Niagara, and Moore's Early. Two of my neighbors have grapes that they do not know the name of that beat all the others. Grape crop is very good this year, and is surer every year than any other fruit.

B. Leonhart, Kiowa, Barber county: I have 200 vines, planted on an eastern slope. They are Concord, Moore's Early, and Niagara; would recommend these varieties for low ground and soil with plenty of moisture. Plant one-yearold vines, eight feet apart, in rows sixteen feet apart, and give good care. Plow once and cultivate as often as needed. My trellis is made of posts and wire, running north and south. I prune in summer, because reaction of the sap sends out more laterals to shade the fruit and encourages fruit growth, combats fungi, makes stronger root grow th and healthier fruit-buds for the next year. Market at home.

C. A. Blackmore, Sharon, Barber county: I have about 500 grape-vines growing in dark sandy, light sandy and dark red soil; set one- and two-year-old vines, seven feet apart. Prune any time during the winter when not frozen. For a trellis, I use posts twenty feet apart and three wires. Cultivate with a doubleshovel, a stirring plow, and a disk harrow, which I consider necessary for the work. I mulch with three or four inches of loose earth; do not mulch with manure as some others do, as it causes the roots to grow too near the surface, and then during drought they die, or winter-kill the following winter. I rub the sprouts off during the summer. Have tried Concord, Rogers's Late White, Niagara, Worden, Lady Washington, Delaware, Moore's Early, Woodruff Red, Diamond, Hicks, Early Ohio, and several other varieties; experimental varieties not yet fruited are: Missouri Reisling, Pocklington, Colrain, Alice, McPike, Brighton, 
and Campbell's Early. All of the above varieties seem very hardy; the Hicks seems very hardy and extremely easy to propagate. All have done well so far. I would recommend Early Ohio, Woodruff Red, Diamond, Concord, Moore's Early, Niagara and a few others for this locality. Gather the fruit with grape pickers. They are a paying crop if the right man plants the right varieties. Have never sacked the fruit. I have a forty-acre orchard, fenced in, and under the fence I have vines planted, which are doing well and are full of grapes at this planting; they bore well last year. As it was necessary to fence the orchard in, I utilize the fence in this way as a trellis. Of course it is necessary to keep the "fence" well cultivated. The Hicks grape did splendidly with me this year (1901). They were large and fine, ripened all at one time and before the Concord. I have two fine, extremely hardy, wonderfully productive, rapid growing raisin grapes. They are, I believe. called Tokay. The first begins to ripen just after Concord is gone, is oblong and pink in color, remains long on the vines, and keeps a long time after picking. 'The other ripens a little later, is round, and hangs on well. I have thirty vines of each now in bearing. The two parent vines have been well tested here for ten years or more. One of them grew more than fifty feet this year, and bore grapes fifty feet from the trunk, on a lightning-rod. They are just grand for covering arbors, porches or summer-houses, and the quality of the fruit cannot, in my estimation, be excelled.

Ben. McCullaugh, Ellinwood, Barton county: I have over 200 Concord grape-vines, planted on black sandy soil having an eastern aspect. I prefer oneyear-old vines, set eight to ten feet apart. I cultivate with the plow and harrow. I prune in March. My trellis is made of posts and barbed wire. I never summer prune. I have never bagged grapes. I cut my grapes from the vines with a sharp knife. I have a home market within twenty miles. Grapes are a paying crop here.

Geo. T. Elliotr, Great Bend, Barton county: I have 400 grape-vines, planted on an eastern slope. They are Concord, Moore's Early, and Rogers's No. 22. I prefer two-year-old vines, set eight feet, in rows ten feet apart. Cultivate with a double-shovel plow. Prune in the spring. My trellis is of wire, built five feet high. Do not summer prune, as I want the vines thick on account of birds. I have never bagged my grapes, but my neighbors have, and I think it a good plan. I sell my crop among the neighbors. Grapes would be a paying crop if the birds and grasshoppers would leave them alone.

JACOB ReDiger, Great Bend, Barton county: I have Concord grapes, set on sandy clay soil which slopes to the south. I plant one-year-old vines, $6 \times 10$ feet. I prune in February; also prune a little in summer, as I think it makes the fruit better.

J. B. SAxE, Fort Scott, Bourbon county: I have half an acre of grape-vines, planted on clay loam which is about level. Set one-year-old vines, eight to twelve feet. Prune during the spring by cutting back pretty well; do not summer prune. My trellis is three wires above the vines. Till with a one-horse cultivator or plow. Have never mulched, but think it would be beneficial. Have tried only Concord, but intend putting out some Campbell's Early. Concord is the only variety that has done well enough here to be recommended. Gather and market in ten-pound baskets, in Fort Scott. Do not think they pay, and would not advise planting them extensively. Have never bagged the fruit.

R. A. Williams, Glendale, Bourbon county: I have thirty grape-vines, planted on limestone soil sloping to the east. Set one-year-old vines, eight by ten. 
feet. I prune closely during the winter and early spring; also prune during the summer by cutting back to within one foot of the bunches. I use single stakes for a trellis. Care for them with a cultivator and hoe; think a double-shovel and five-tooth cultivator the best tools for this work. Do not mulch. Have tried Concord, Ives's Seedling, Wilder, Moore's Early, and Dracut A mber. Discarded Dracut Amber; it is a good bearer but poor flavored. I would recommend Concord and Moore's Early for this locality, although Concord does best. Gather my grapes as soon as thoroughly ripe and sell for from three to five cents per pound. I consider them a paying crop for home use. Have never sacked them. Have put up unfermented grape juice - canned it in Mason jars.

R. C. Chase, Hiawatha, Brown county: Have one-fourth of an acre of grapevines, planted on light, sandy upland, sloping slightly to the east. My varieties are Concord, Moore's Early, Worden, Pocklington, Niagara, Empire State, Agawam, Delaware, Lindley, and Perkins. Have discarded Niagara, Perkins, and Empire State, because they are not hardy. Would recommend Concord, Worden, Moore's Early, Pocklington, Lindley, Delaware, and Agawan. I prefer oneyear-old vines, set six feet apart. Till with cultivator and hoe. Prune on warm days in February; cut the new wood back to two or three buds; cut out all dead or nearly dead wood; do not summer prune, as I do not have time. I use posts and wire for trellises. Have never bagged my grapes, because I do not think it would pay. I cut my grapes into baskets with shears; market at home. Other fruits pay better here. Have put up unfermented grape juice in small quantities.

B. F. Oxley, Morrill, Brown county: I have been successful in raising grapes by careful pruning and thorough cultivation. I have seventy-five grapevines, planted in deep, level loam. The varieties are Concord, Moore's Early, Elvira, and Brighton. I would recommend, for trial, Worden and Moore's Diamond. I prefer one-year-old vines, set eight feet apart, in rows ten feet apart. Till with a five-shovel cultivator and hoe. Prune the new growth back to two buds in February. My trellis is of three wires and posts eight feet apart. Prune some in the summer, to shorten the long, new growth and give sunlight where needed. Have never bagged my grapes, and would not advise it, as I do not think the gain in value would pay the cost of bagging. Our soil, for miles along the Missouri river, is excellent for grapes.

NeIl Hansen, Willis, Brown county: I have 200 grape-vines growing on black soil over a clay subsoil which slopes to the west. I prefer a southeast slope. My varieties are Concord and Brighton. I would recommend the Concord, as it is a good bearer and easily tended. I have had good success with it. I prefer two-year-old vines, set six feet apart; cultivate with shovel plow. Prune in February, leaving two or three canes. My trellis is of posts and three No. 9 wires. I do very little summer pruning, as the sun affects the fruit too much. I sometimes mulch my vines, but would not advise it, as it draws mice and insects to them. Cut the fruit with a knife or scissors; market at home, realizing two cents per pound. They are a paying crop when cared for.

J. J. Johnson, El Dorado, Butler county : I have 100 grape-vines growing on a western slope of rock shale which runs down to good valley land. I like a slope into a wide valley, as I do not lose so much fruit from frost; have best results on western slope; the vineyards on eastern slopes and level land are all dead. I set s trong one-year-old vines, seven and one-half feet north and south and eight feet east and west. I prune during nice weather in late winter or early spring; cut back all new growth to three buds; never summer prune in Kansas. For a trel- 
lis, I use hedge stakes five feet high; use shorter ones on higher and poorer land, as a low vine shades the ground better; cultivate as often as a crust forms, as many as fifteen times during a season; besides I keep the weeds all cut out. I use a one-horse cultivator and harrow; keep a perfect dust mulch during hot and dry weather; I never mulch. Have tried Concord, Worden, Niagara, Pocklington, Elvira, Dracut Amber, and Merrimac; have discarded all but Concord and Worden as unprofitable; Concord, Elvira and Worden do best here; I would recommend Concord. Gather in twenty-pound baskets, and sell mostly in the vineyard, receiving from one to four, generally two and one-half, cents per pound ; they are only a fairly paying crop; the yield is not beavy enough, but the quality is always good. I would not advise extensive planting. Our fruit is never troubled by birds, insects, nor rot, although the vines are affected by several insects. Have never sacked the fruit.

R. H. Chandler, Bazaar, Chase county : I have seventy-five Concord grapevines, planted in a black loam twelve feet deep which is level. I have tried many varieties, but they have mostly discarded themselves. I prefer one-yearold vines; have tried older ones but without success; set them eight feet apart; do not cultivate after the vines are three years old; prune from November to February. My trellis is of wire, but I would use wood if in a windy place. Summer pruning ought to be done in some places. Have never bagged my grapes, and have never seen it done. I set out only enough vines for family use, although we sell some every year; receive from three and one-half to four cents per pound, while those raised on upland can be bought for one-half less. My vineyard is protected by timber; also by a barberry hedge.

Chas. Pflager, Elk, Chase county: I have 100 grape-vines growing on extragood bottom land which slopes to the southwest; am growing Concord and some other varieties. I would recommend only the Concord. I have experimentally tested a white grape and the Catawba. I prefer two-year-old vines, set six feet apart; till with hoe and cultivator; prune in February and also some in summer, to improve the fruit. I cut the fruit from the vines and market at home. I consider them a paying crop.

Muke Gamer, Strong, Chase county: I have fifty Concord grape-vines, planted on upland sloping to the south. I would recommend this variety, with which I have had good success. I prefer two-year-old vines, set eight by eight feet, cultivated with a hoe and kept clean for three years; then mulch. Prune very little. I think there is big profit in grapes.

F. Starkey, Elmdale, Chase county: I am growing the Concord and a white grape on a southeastern slope. I recommend Concord. I prefer one-year-old vines, set six by eight feet; till with a plow and double-shovel. Prune in March, leaving two canes. My trellis is wire. Do not summer prune, on account of hail. Do not bag the fruit. Gather in baskets and market in the city, realizing fifty dollars per acre, which I consider good pay. I have forty-eight Concord grapes situated on what is known as "plains marl," underlaid with a hard-pan about a foot from the surface, having a slight eastern slope. Tried Clinton several years ago, but discarded it because it was barren. I plant one-year old vines, in rows three by eight feet. I turn the ground up two or three times a season with a four-tined fork, hoe, and pull out the weeds. Use posts and two wires for a trellis, but do not like it; will make a trellis next spring in the form of a roof, of narrow board and wire. Prune in February, by trimming to two best vines. Have not summer pruned any, but believe it a good method. This is the first year I 
have had grapes in bearing, and think they are one of the fruits that can be grown here. They have been winter-killed the past two winters; I think they should be protected for a year or two after planting. Have irrigated for two years and expect to do so in the future, in order to get good results.

W. P. McKeE, Cedarvale, Chautauqua county: Have 200 grapes in all; part are planted on sloping limestone, the balance are in a valley. I prefer an eastern slope. Set one-year-old vines, either ten or eight by ten feet. Prune in February; cut away all of last year's growth excepting two buds. Use a trellis of posts and wires. Till them with a cultivator between the rows and a hoe around the vines. Have never tried mulching. Have tried Concord, Dracut Amber, Worden, Pocklington, Vergennes, Elvira, and Niagara; have discarded Niagara, Pocklington, Worden, and Vergennes, as they will not stand dry weather on valley land. Those that do best here are Concord, Dracut Amber (if planted on a slope), and a white variety which is extra fine and an abundant bearer. I consider grapes a paying crop and would advise extensive planting in this locality. Have never sacked the fruit.

Jere Ellexson, Chautauqua, Chautauqua county: Have 140 vines growing in sandy loam with clay subsoil, sloping to the south. Have tested three varieties and discarded none; would recommend Moore's Early and Concord. I plant yearling vines, eight feet apart; cultivate with one horse, five-tooth cultivator and hoe. Prune in January and February, not later than the 10th; use a common pruning knife; have summer pruned, but it does not pay. My trellis is a post seven feet high for each grape-vine, with a crosspiece two and one-half feet long. Have not sacked grapes, but would advise it. Cut, sort, and pack in ten-pound baskets; market in Sedan and Chautauqua; receive one to two cents per pound.

Thomas H. Guest, Grafton, Chautauqua county: Have thirty acres of grapevines. A deep, black, sandy loam is the best soil; a southeastern slope is best, because they get all the morning sun, which prevents black rot and gives them a better flavor. My varieties are Concord and Moore's Early. Have discarded Moore's Early, because of black rot and bird's-eye rot. Concord is a success under all conditions. Plant one- or two-year-old vines, eight by ten feet. Til 1 with a five-toothed cultivator and scraper, forming a dust mulch, which will insure against the droughts of July and August, while the fruit is ripening. Prune in February, cutting out one-half of new wood, and leaving three buds to a cane. Summer prune with corn-knife, to make clusters more vigorous. My trellis has two No. 12 wires. Do not bag my grapes, as I think the grapes more vigorous and better flavored without. Gather with knife or clippers into eight-pound baskets; market in Colorado and Oklahoma territory, realizing forty dollars per acre. They pay. Have put up unfermented grape juice; we heat the juice, skim, and put in self-sealing cans. For black and bird's-eye rot, spray with Bordeaux mixture once before leaves start, twice thereafter, or as often as necessary. This mixture will surely prevent these two diseases. Either Paris green or London purple will destroy all leaf-eating insects.

A. S. Denison, Columbus, Cherokee county: I have about fifty vines, planted on a gray loam with a clay subsoil and an eastern slope. I set out one- or two-year-old vines, six by eight feet; prune in February, by cutting back; do not prune during summer. My trellis is eight feet high, having wires on the sides and top. Do not cultivate; I pull the weeds and keep the grass cut short with the lawn-mower; mulch my vines. Have tried Concord, Dracut Amber, Clinton, Delaware, and Isabella. Have discarded Clinton, Delaware, and Isabella, because 
they do not do well. Concord does best here, and I would recommend it for all purposes. Gather in baskets; market at home, receiving one to two cents per pound. They do not pay for market, but do for family use, as they are very healthful, and a family that knows how will consume great quantities while fresh and put up many for future use. Would not advise planting entensively. Have never bagged my grapes. We have put up unfermented grape juice. "Pick on stems when fully ripe; immediately press in cider-mill; heat the juice without delay to boiling-point; then can."

D. S. Stebins, Columbus, Cherokee county: I have half an acre of grapevines set on sandy loam. Planted two-year-old vines, eight feet apart. Prune in February to one or two buds on the new growth. My trellis is made of hedge posts. Cultivate during the summer with a small-bar plow and double-shovel, which I think best. Do not mulch. Have tried Concord, Niagara, and Moore's Early. I would recommend the first-named variety for this locality. Market them in the mining towns, receiving from two to five cents per pound. They are a paying crop to a limited extent, but I would not advise extensive planting. Have not sacked any fruit.

A. R. McCallum, St. Francis, Cheyenne county: I have 100 grape-vines growing on bottom land only eight feet to water. I prefer level land, but of slopes I think an eastern best. Set yearling vines, eight feet apart. Prune in the fall, leaving spurs of two buds of the past year's growth. For a trellis I use a low stake. Till with a disk and spring-tooth harrow, which $I$ think are best. I do not mulch, but cover them with dirt in late winter. Have tried Concord, Worden, Moore's Diamond, and Niagara. Have discarded Moore's Diamond and Niagara, as they are too tender. I would recommend Worden and Concord for this locality. They are a paying crop for home and not for commercial use, and would not advise planting extensively. Have never sacked the fruit.

B. F. Campbell, St. Francis, Cheyenne county : I have about 100 grape-vines of all kinds growing on level, sandy soil. We are not very successful on account of grasshoppers and lack of care. I prefer two-year-old vines, set eight feet apart. My best grapes are mulched with old hay. I prune in the fall. My trellis is made of wire and posts. I never summer prune, for lack of time. Have never bagged any. They are a paying crop here when taken care of.

Chas. G. Boone, Ashland, Clark county: I have one-quarter of an acre of grape-vines growing on low, black land that overflows. I think a northern slope preferable. Set one- and two-year-old vines, twelve feet apart. I use the posts in a wire fence for a trellis. Cultivate with a disk harrow to keep the soil loose on the surface. Mulch my vines on dry land. Have tried Concord, Worden, and Pocklington. I would recommend the first-named variety for this locality. I market at home, receiving three cents per pound.

Theo. Olsen, Green, Clay county: Have about 200 grape-vines, planted on deep black loam sloping to the north. I plant three-year-old vines, six feet. I prune in February or March. Mulch with straw. Do not summer prune, because the sun will scorch them. Use our crop at home. I consider them profitable.

JoHn Reed, Longford, Clay county: Have 150 grape-vines, planted on south slope; varieties are Concord, Elvira, and Moore's Early. Recommend Concord and Elvira - the latter for canning purposes; the vines are strong, healthy, and fruitful, but not as fruitful as Concord. I plant one-year-old vines, eight feet each way; cultivate very shallow with plow, and use hoe close to vines; prune 
last of February; would not recommend summer pruning in this locality. A trellis with two wires, one eighteen inches from the ground and the other one foot higher, I think best. Cut the grapes off the vines; the home market takes all we have to spare. I consider them profitable and the best fruit crop for this part of the country.

A. D. Arnold, Longford, Clay county: Have 250 grape-vines growing on sandy loam with clay subsoil sloping south. Varieties are Concord, Niagara, Pocklington, Agawam, and Dracut Amber; Niagara and Pocklington died. Would recommend Concord for general use. Plant two-year-old vines, ten feet apart. Till with a one-horse hoe and a five-tooth cultivator. Prune in February and March; do not summer prune. I think posts and wire make the best trellis. Have never bagged grapes. Market at neighboring towns; but the most of the crop is used at home and given to friends. I think they pay. Seventeen years ago I set 200 Concord grapes, and have had fourteen crops from them; they were once burned by fire from passing trains, and one year the frost killed them. My grapes have been the best investment in fruit I have made in central Kansas, the hot winds, terrible droughts and sun affect them least of any fruit.

I. N. MACY, Longford, Clay county: I have about 100 grape-vines, on valley land; they are Concord and Moore's Early. I prefer two-year-old vines, set $8 \times 8$ feet; cultivate with the hoe; then mulch; prune in winter. My trellis is made of posts and wire. Have never bagged the fruit, and don't know whether it is advisable or not. We always have a good home market, as we raise only for family use. I think them a paying crop, as the demand exceeds the supply, for there are so many who are unwilling to take the care which is necessary for success. I consider the Concord a sure cropper ; nearly all others are uncertain.

S. H. Domony, Aurora, Cloud county: Have about thirty grape-vines, set on limestone soil, sloping north; they are Concord and Moore's Early; both these varieties are hardy and do well here; plant one- and two-year-old vines, eight feet apart; till with a cultivator, and then mulch with coal ashes or cinders; prune with a knife. My trellis is of hedge posts and wires. Gather as we need them; use all at home. I think they would be a paying crop if planted more extensively, which I think ought to be done, both for family and market purposes.

H. A. Davis, Concordia, Cloud county: I have seventy-five grape-vines growing on black loam; they are Concord. Moore's Early, and Niagara; they have been planted but two years, and have not yet fruited. I prefer one-year-old vines, planted four feet each way; cultivate them with a one-horse cultivator.

A. Munger, Hollis, Cloud county: I have one acre of grape-vines growing on sandy loam. They are Concord, Elvira, Clinton, Niagara, and Worden. Have discarded Moyer and Delaware, as they winter-kill. Would recommend Elvira, Concord, Niagara, Delaware (if protected), and Clinton, in the order named. I have, experimentally, tried Moore's Diamond, which winter-killed. I prefer oneand two-year-old vines, set six feet in the row, and the rows eight feet apart; cultivate with a small shovel cultivator. Prune in late winter or early spring. My trellis is of posts and wire. I prune some in summer, but care must be had to allow sufficient leaves to shade the fruit and ground. Have never bagged my grapes, but have seen some good results in other places, and can see no objection except the labor involved. Cut the grapes from the vines with scissors. I consider grapes a light-paying crop. In my first experience, or rather I mean my lack of it, I mulched my vines; this induced a growth of roots under the mulching on top of the ground. Cultivation then threatened the life of the vines, 
and the mulching had to be continued; this mass of mulching made a great insect harbor, and in a few years little brown borers killed the vines to the ground. Have since cultivated with better success. Elvira stood winter and all unfavorable conditions best of all; Clinton did very well. The winter of 1898-99 killed most of the vines in this county to the ground, yet some vineyards did not seem in the least injured, and produced a crop the following year.

Johnson Keller, Arkansas City, Cowley county: I am growing Concord, Worden, Niagara, Delaware, Martha and Ives on rich, black, sandy loam, which causes them to grow too largely to vines; my land slopes slightly to the east and south. I have discarded all excepting Concord and Worden, because of rot. Those two do the best in my soil. I spray every year, but so far have failed to stop the rot. I prefer one-year-old vines, set eight feet apart; cultivate with a shovel-plow; prune closely in February. Have a wire trellis. I summer prune, and think it makes the grapes larger. Have never bagged grapes, and do not advise it, as I do not think they are as good to eat. Gather in small baskets and market at home. I realize from thirty to fifty dollars; they do not pay with me. Have put up some unfermented [?] grape juice; we put the grapes in a barrel and pound well, let leach, put into a whisky keg, and cork tightly; keep in a cool place. I have watched grape culture in Kansas for twenty years, and am fully convinced that a limestone soil is much better for grapes than rich, sandy bottoms. They do well in this county on the poorest upland limestone soils.

J. H. Bilsing, Udall, Cowley county: I am growing Concord, Dracut Amber, Delaware, Niagara, Empire State, etc., on level black loam mixed with sand. Have tried and discarded Prentiss, Clinton, Goethe, and Pocklington. I would recommend Delaware, Concord, Niagara, Dracut Amber, Empire State (this latter variety rots and drops badly some years), Moore's Early, Brighton, and Hartford, which is similar to Concord, but larger. Varieties tested experimentally are Agawam, Early Ohio, Ives, Worden, and a seedling of fine quality, medium early. The three first are just beginning to bear. I prefer vines one year old, set eight feet apart; till with hoe and cultivator; prune in early spring. At present, for supports, I use stakes only. I consider them a decidedly paying crop for the labor expended on them. I have had excellent success with grapes when mulched with old hay or straw. They were about as near perfection as we can get them in this hot, dry climate. They were of good size, color, and excellent quality, and hung on much longer than those that were not mulched; in fact, I think that is the most successful way, barring irrigation. But I also find that when once mulching is applied, it should be kept on and renewed, for if once removed the vines are at once checked in growth. Mulching seems to induce the roots to come nearer the top of the ground, and the reaction from its removal is certainly injurious, as the fruit shows for itself. Some seasons grapes rot and fall badly, but I think the birds cause a greater loss every year. Have of ten thought of bagging, but, as yet, have not tried it.

J. Moncrief, Winfield, Cowley county: I prefer a sandy loam, or upland fertilized with bone; an eastern slope is best for the fruit, but they will do well on level ground. I have Concoru', Worden, Moore's Early, Niagara, Pocklington, Norton's Virginia, Agawam, Elvira, Goethe, Iona, Moore's Diamond, Diana, Wyoming Red, Salem, Dracut Amber, Perkins, Ives, Lindley, Clinton, and Delaware. I would recommend Moore's Early, Worden, Concord, Niagara, Moore's Diamond, Agawam, and Goethe. I plant one- or two-year-old, No. 1 vines; weak-growing varieties eight feet apart; strong-growing varieties eight to 
ten feet apart. I work the ground deeply until they come in bearing, then cultivate shallow, for dust mulch. Prune by cutting back to two buds in the fall, any time after the wood is ripe, and until March. My trellis is a wire, or strips of boards, running parallel with the row. Summer prune when the season is wet, as then the growth becomes too rank; this saves strength for maturing the fruit. In dry seasons I do not summer prune, but save the foliage to keep the fruit from burning. Bagging grapes is a success, as it keeps insects and bees from the fruit. Gather by clipping the bunches with a sharp knife into a fruit basket. I prefer the five-pound basket. have tried and discarded Ives, Perkins, and Clinton, quality no good, excepting for wine; Delaware, quality fine, but the vine is not hardy in this locality; Pocklington, quality O. K., but ripens uneven; Norton's Virginia no good excepting for wine, for which it is very good. Other varieties are good here, but the list recommended do best.

J. A. Whiteside, Girard, Crawford county: I have 925 grape-vines growing on light, sandy soil; a southern slope is preferable. Set first-class one-year-old vines, eight by eight feet, with sweet potatoes between. Prune the 1st of December and the latter part of May. For a trellis I am using a catalpa-post railing, but if I wanted wire I should use barbed wire. For tillage. I use a five-tooth cultivator, a double-shovel plow, and a small diamond plow. Mulch during the fore part of winter with coarse stable litter. During the summer I cut the vines back to the second joint from the fruit; later I cut back the laterals. Have tried Concord, Moore's Early, Dracut Amber, Elvira, Worden, Niagara, Pocklington, Salem, Campbell's Early, Early Victor, Agawam, Goethe, Findley, and Clinton. Those which do best here are Concord, Moore's Early, Niagara, Agawam, and Early Victor. I would recommend Concord for all purposes. They are a paying crop, but there are better-paying fruits. I would not advise extensive planting in this locality.

L. M. HowaRD, Girard, Crawford county: I have 200 grape-vines, planted on level black and gray land. I prefer one- to two-year-old vines, set ten by ten feet apart. Cultivate with a plow and cultivator. Prune in January and February. My trellis is made of wire. I prune in summer to let in the sun and air, which improves the size. Have tried bagging them, but would not advise it. [Why?] Gather with a knife; pack in baskets; market at home. Realize forty dollars per acre. I consider that they pay for home use.

Alfred Wilson, Pittsburg, Crawford county: Have 200 Concord grape-vines. I would recommend Concord only, as it leads all others in this part of Kansas. I plant two-year-old vines, eight feet apart. Cultivate with a plow, hoe, etc. Prune early, before the sap starts, leaving two buds on new wood; do not summer prune. I think wire trellis is best. Do not bag any. Cut with pruning shears; market at home. They pay.

J. H. SAYles, Norcatur, Decatur county: We planted Concord, Moore's Early and Worden in 1890, and in 1891 and 1892 had fine grapes, but in 1893 and 1894 they all died from drought. We must irrigate, or we cannot raise grapes here; I have been a fruit man forty years, and will sink more wells. Plant my vines four by eight feet. Till with a small cultivator and a drag. Prune back to two buds in November; I also summer prune, because it increases the fruit. My trellis is posts and wire. Have bagged my grapes, and advise it for family use, as we get cleaner and sweeter fruit. They have not yet been profitable.

W. D. Street, Oberlin, Decatur county: Have fifty vines, planted on level, sandy bottom land. My variety is Concord. Late frosts and grasshoppers have 
ruined my prospects year after year. A farmer twelve miles west of here did market very fine grapes in Oberlin, but his vines have since died. I really believe we will raise grapes here some time, as wild grapes grow in abundance.

P. T. Johnson, Oberlin, Decatur county: I am successful in growing oneyear-old vines, but no grapes. I now have twenty-five Concord grape-vines, planted on black loam two feet deep, with a subsoil of magnesia sixty feet deep. My land is level prairie. Have tried and discarded Catawba, because it will not grow more than one year here. Have experimented with Worden and Moore's Early, both of which died during the winter of 1898-'99. I prefer two-year-old vines, set six feet apart. Till with a corn cultivator.

James Dunlap, Detroit, Dickinson county: Have three-fourths of an acre of grape-vines growing on black loam sloping to the east. Would recommend Concord. Plant two-year-old vines, six feet in the row, and the rows eight feet apart. I do not cultivate, but mulch every second year. I prune to two buds in latter part of March. Do not prune during the summer, as it would expose the bunches to the hot sun. I think a small Osage orange post at each vine and two smooth wires make the best trellis. Do not bag any. It is too expensive. Gather my grapes by cutting or pinching the bunches off. Pack in eight-pound baskets. Market in neighboring towns. They have been profitable with me.

A. M. Engle, Moonlight, Dickinson county: Have about 150 grape-vines growing on an eastern slope. They are mostly Concord. Have tried and discarded Moore's Early as not profitable. Would recommend Concord, Worden, and Moore's Diamond. Set the vines eight feet apart; cultivate as for garden crops; keep clean of weeds. Prune in October and November, also in March ; do some summer pruning, to concentrate the strength of the vines. I consider them profitable. Our experience has not been large in special grape culture. Have planted and had bearing vines for over forty years, mainly for home use, selling the surplus as best we could, generally in towns. I think here in central Kansas grape culture could be made a success, and a paying crop, with proper soil and location; but more sure and successful with irrigation. I am so convinced that irrigation is essential to success in almost any line of horticulture that I would put much stress or stock in an irrigation plant, were I to embark in any of these industries.

L. A. SHow, Highland, Doniphan county: I have fifty grape-vines growing on black loam having a clay subsoil, sloping to the northeast; set two-year-old vines, $8 \times 10$ feet apart; in pruning, I leave two buds to the spur and three arms to each root; never summer prune; my trellis consists of posts and three wires; cultivate shallow with a disk harrow or five-tooth cultivator; frequently mulch with ashes; have tried Concord, Goethe, Cottage, Moore's Early, Moore's Diamond, Niagara, Green Mountain, Early Ohio, Delaware and Hartford Prolific; have discarded Delaware, Moore's Diamond, and Niagara, as they are too tender for this climate; the Concord, Moore's Early, Niagara, Worden, Cottage and Pocklington do best here; I would recommend Moore's Early, Concord, Niagara, and Worden; they are a paying crop, but I would not advise planting extensively ; have sacked my grapes, but without good success, although, if put on in timejust as soon as the bloom falls - they are beneficial ; I never put up unfermented grape juice, for I am in sympathy with Major Holsinger's temperance views - it might ferment.

Bert Montgomery, Troy, Doniphan county: Have one-half acre of grapevines on land sloping to the southwest. Varieties tested are Concord, Hartford, 
Ives, Moore's Early, and Worden. Have discarded Hartford, Ives, and Delaware. Recommend Concord, Moore's Early, Worden, and Niagara. Have experimented with Goethe and Pocklington; neither is a good bearcr. I plant two-year-old vines, six feet apart, in rows eight feet apart. I till shallow with a small plow. Prune in February or March; never summer prune, because the grapes ripen and mature better in the shade of the foliage. I think trellises made of posts and wire are best. Do not bag any. Pick by hand - do not use a knife - in eightpound basket. Market in western Kansas and Nebraska. Realize about thirty dollars per acre. I consider them a good, paying crop. One-quarter of an acre will pay any family well for home use. We put up unfermented grape juice; press the juice out with a cider-press and then raise to boiling-point and can. The market is not as good as it was ten or fifteen years ago; still one and onehalf cents per pound, with a good yield, will pay better than most other farming. When I ship them I usually get two cents or more per pound.

A. H. Griesa, Lawrence, Douglas county: Haveabout one-half acre of grapevines, on black prairie land which is nearly level; they are mostly Concord, with some Worden, Moore's Early, Pocklington, Niagara, Delaware, Wilder, Goethe, Agawam, Lindley, Dracut Amber, and Elvira. A great many should be discarded, such as Maxatawney, Herbemont, Norton's Virginia, Jefferson, and Missouri Reisling; would recommend Woodruff's Red, Lutie, and, for late, the Columbian might be tried. I have experimentally tried the three latter varieties and Campbell's Early, Hicks, McPike, Lucille, Daisy, and St. Louis; these have not all fruited yet. I plant one- and two-year-old vines, in rows $6 \times 7$ feet; cultivate as near clean as time will permit; prune in January and February. I think a three-wire trellis, having posts twenty feet apart, is best. Summer prune a little, to stop too rank a growth. Have not yet bagged any; it would pay if the price of grapes was better; but it is too expensive with the present prices. Cut from the vines with a knife, and pack in $O$. A. nine-pound baskets; market mostly at home; they are not a large-paying crop. I have in former years put up unfermented grape juice; press out the juice, boil it, and put up as canned. Grapes growing in the valleys of the Missouri and Mississippi rivers do not produce excepting in a limited way, on account of the rot so prevalent most every season; farther north, west or south they seem to rot less; here, only the more rot-resisting kinds should be grown. The kind of land, slope, and culture, as well as the varieties, are soon found out by every observing man, if he plants them. But for family use in the large region where we live, and where we ought to have them in our yards, is the place to study as to best culture, best kinds, and other details, as the few each family must have to supply one of the choicest fruits for home consumption is time and thought well invested, and thus we find varieties adapted to our place and our taste. For general purposes the Concord fills the place for many; Moore's Early does well, as also does Worden; Martha, for an early white variety, is good. One thing needing attention is to trellis them; on a trellis they can be spread to give them needed air and light, so essential to good fruit. We need here a later grape than any we now have; all ripen too early, while the temperature is high and insects plentiful, which soon ruin them after they are ripe. Nothing in Professor 'Munson's list, that I have tried, is adapted to our state.

A. C. Griesa, Lawrence, Douglas county: Any well-drained soil with any slope will raise grapes; but the warm, sunny slopes are preferable; the fruit is not so liable to rot when it has plenty of light and air. Have tested most of the sorts in use twenty years ago, but discarded them because they were not profit- 
able. Would recommend Concord, Worden, Moore's Early, Ives, Early Ohio, Hartford, Delaware, Brighton, Martha, Niagara, Moore's Diamond, Pocklington, and Lutie. We have succeeded well with all we have tried. Plant No. 1 yearling vines, ten by twelve feet. Till with an ordinary cultivator. Prune after hard freezing is over, say February 15 to March 1 . Do not generally summer prune; if done they throw out laterals and the wood is of ten imperfectly ripened. I think a trellis of three wires six feet high is best. I bag my grapes, but do not advise it; it does not pay, except in rare instances. Cut the clusters from the vines. I prefer nine-pound baskets; sell at home market. I think them a moderately paying crop. We have put up unfermented grape juice; we heat the juice, sweeten, skim, and seal up in bottles.

William Plasket, Lawrence, Douglas county: I planted one acre of grapevines on good, light upland soil, but they are decaying badly. I prefer an eastern slope. Set yearling vines, eight feet apart. Prune closely in the fall or mild winter weather; also prune in the summer, when the vines become too long and numerous, leaving two or three canes for bearing the following year. I use posts and smooth wire for trellis. Till with.a common cultivator and small plow, which are best for this work. I do not mulch, but think it would be beneficial. Have tried Concord, Virginia Seedling, Moore's Early, Dracut Amber, and Norton's Virginia. Isabella, Catawba, Clinton and Martha have been unsatisfactory, as they ripen late and are of poor color. Those which do best and that I would recommend for this locality are Concord, Moore's Early, and Norton's Virginia. Gather, sort and pack my grapes in nine-pound baskets; sell anywhere I can find a market. They do not pay and I would not advise extensive planting. Have never sacked any.

Harry Angus, Lewis, Edwards county: Have fifty grape-vines, planted on black loam. Set two-year-old vines, eight feet apart. Prune back to two-bud spurs in February; also prune during the summer on bottom land. I use a wire trellis. Cultivate with a one-horse cultivator. Do not mulch. Have tried Concord, a red, and a white grape. The Concord does best, and I would recommend it for this locality. I consider them a paying crop for home use, and would advise planting extensively. Have never sacked the fruit.

Aaron Zeiner, Elk Falls, Elk county: I have 800 vines, and they are hanging full of grapes; they are planted on a loose, rich, sandy soil, which I consider best, sloping to the south just enough to drain well. Concord is my best grape, Moore's Early comes second; they are both strong and vigorous growers. I have five varieties of white grapes, only one of which is good. Plant two-year-old vines, eight feet each way; cultivate very shallow with a one-horse plow; prune in February; do not summer prune, as the sun would dry the fruit up. My trellis is wire. Have not bagged my grapes. I could not afford to spend so much time for the difference in profit, and would not encourage it, as it is too expensive. Gather them with shears. They are too cheap to sell. I think they would be a paying crop if taken care of, as they are so sure. Grapes must be kept up off the ground, and not planted near timber; they must be kept clear of grass and weeds, and must be cultivated shallow and not close to the vines, as this would tear them up; a hoe should be used near the vines and in the row.

S. D. Lewis, Howard, Elk county: I have a half acre of grapes on sandy soil, with clay subsoil. Planted two-year-old vines, $6 \times 8$ feet. Prune closely, to two or three buds, in February; also prune to a small extent during summer, to prevent too much growth of vines. I have a stake at each vine, with two wires. 
Cultivate very shallow with small shovels. Do not mulch. Have tried Concord, which I would recommend for this locality. Cut the bunches in baskets or boxes, and sell in local market, receiving two cents per pound. They pay, but I would not advise planting extensively. Have never bagged my grapes.

J. C. Weathers, Howard, Elk county: I have forty square rods of grapevines, planted on second bottom having a clay subsoil, which is quite flat and level. Side-hill limestone soil is best. Set two-year-old vines, $6 \times 8$ feet. Prune in February to two or more buds, according to vine. Use a trellis of seven-andone-half-foot hedge posts and three wires. Cultivate clean, with a one-horse, fivetoothed cultivator. Do not mulch. Have pruned some during summer, but will do so no more. Have tried Concord, Worden, Moore's Early, Pocklington, Dracut Amber, and Champion; discarded Pocklington and Dracut Amber. Those that do best, and I would recommend for this locality, are Worden, Moore's Early, and Concord. Sell in local markets. They are a paying crop, but I would not advise extensive planting. Have not sacked the fruit, but think it would pay. Mulch heavily with barn-yard manure, but think the land should be tiled, as often after heavy rains it is much too cold. Have no protection for the vines from winds and storms. Think protection by a heavy belt of timber on the north and west would be beneficial. Cultivate with a five-toothed cultivator, followed by a hoe in the hands of a careful person, making sure that no weeds are left, and continue until after the crop is gathered, provided no more weeds appear; keep them out by all means. I have fine, large grapes and plenty of them, while my neighbors grow weeds and very poor grapes on the same kind of land. Clean cultivation is better than mulching. I tried cutting back the young vines during summer, so that I could get closer to the rows with my cultivator, but found it was injurious, killing many of them back to the old vine, besides exposing the berries to the hot sun, and many were badly sunburned. I place Worden first, Moore's Early second, Concord third, and Isabella fourth. Dracut Amber is a fine, large grape, but sunburns easily and is not good flavored. The Pocklington is a fraud; I have not got anything from it so far. I let the berries get well ripened before gathering. Contract them in our near-by towns. Gather in twenty-five-pound boxes and baskets, cutting off all spoiled or defective grapes. Get four cents per pound for the Worden and Moore's Early, and two to two and one-half cents per pound for Concord. Think them a far better paying crop than wheat or corn. The poultry have the run of the vines, and they pick up any bug, grasshopper or worm found loafing there, never molesting the grapes, as they are well fed on grain. Have never put up unfermented grape juice, but have furnished hundreds of pounds of grapes for this purpose, and have tasted it in the spring and found it just as sweet as though freshly made, and consider it a much better drink than the so-called grape wine; and believe the canning of the sweet juice to be one of the ways of preserving the product of our vineyards, and will no doubt increase the demand for this, one of our finest and choicest fruits.

A. Bolinger, Moline, Elk county: I have forty grape-vines, planted on clay soil having a northern slope, which I consider best. Plant two-year-old vines, eight feet apart each w\&y. Prune short during summer by taking off new branches when too long. My trellis is wire. Till with a cultivator and hoe; mulch some. Have tried Niagara, but it winter-kills; I would recommend Concord, which does best in this locality. Would not advise planting extensively here. Have never bagged the fruit. I do not think it would pay, as there is not sufficient market for it. 
JAmes McIntosh, Hays, Ellis county: I have only a few grape-vines, but am putting out more on bottom land. I think a north slope best, and that the vines need a windbreak. Set them eight feet apart. Till with a cultivator and hoe. I mulch my grapes. Have tried Concord; am putting out Worden and others. Grapes are a paying crop in this county, and I would advise extensive planting, with good cultivation. I have put up unfermented grape juice-canned it, first adding a little water.

Geo. W. McCoy, Wilson, Ellsworth county: I have about half an acre of grape-vines growing on bottom land. Planted yearling vines, ten by twelve feet. Use a trellis of posts and smooth wire. Cultivate with a disk harrow between the rows, and by hand between the vines. The disk harrow is best for this work. I am going to mulch my vines this year. Have tried Concord and Niagara; have discarded none, as my vineyard is young yet. I would not advise extensive planting here.

William M. Sylvester, Garden City, Finney county: I have fifty-three grape-vines, planted on clay soil having some gumbo in it. Set two-year-old vines, eight feet apart. Prune in February; cut off all the small canes, leaving only two main ones; also, cut off all of the shoots which spring from the roots, so as to let sunlight to the fruit. Use a trellis of posts and wires. I plant gardentruck among my grapes, and till with a two-shovel cultivator; any cultivator will keep the soil fine and level. I use fine, well-rotted manure around my grapes. Have tried Concor would recommend this variety and Niagara, as they give the most satisfaction in this locality. Use all of our grapes at home. I consider them a paying crop, and would advise extensive planting, as we do n't grow half enough to supply the home market. I have never sacked the fruit, but other parties have successfully, when they wished to keep some fine fruit for the county fair; but it does not pay.

Nicholas Mayrath, Dodge City, Ford county: I have about one half an acre of grape-vines growing on sandy upland loam. I consider a north slope the best. Set one- and two-year-old vines, $6 \times 8$ feet, but they would do better if farther apart. Prune closely during the early spring; never summer prune. For a trellis I use smooth wire stretched along the rows. Till them the same as corn, with a plow and cultivator. Do not mulch, although it would pay here. Have tried Concord, Ives, Martha, Worden, Clinton, and Delaware. Have discarded Martha and Delaware, as they winter-kill easily. I would recommend Concord and Ives, as they are satisfactory here. Gather my grapes when fully ripe and market in Dodge City, receiving from three to ten cents per pound. They are a profitable crop here, more so than in eastern Kansas. I would advise extensive planting for home market. Have sacked the fruit to a small extent. For a few years past the grasshoppers cut the grapes before fully ripe; this was only in spots. I lost part of my grapes by a swarm of grasshoppers striking them just before ripening and cutting the stems. Wild grapes grow all over this county along the creeks, draws, and streams; why not tame grapes? Our early grape planters set them too close together for southern Kansas, and the dry season killed them on account of it. I tried several varieties; they grew fine, but winter-killed.

R. D. Patterson, Ottawa, Franklin county: I have one and one-half acres of grape-vines growing on river bottom. A southern slope is preferable. Set twoyear-old vines, eight feet each way. Prune early, before the sap runs. For a trellis I use posts and two wires. Till with a cultivator. Do not mulch. Have tried about forty varieties, but find that Concord and Moore's Early do best here. 
Gather in baskets and market at home, receiving one and one-half cents per pound. I do not think them profitable, and would not advise extensive planting. Have bagged the fruit, but it does not pay here.

F. Suritz, Ottawa, Franklin county: I have one acre of grape-vines growing on sandy loam; think an eastern slope preferable. Set one-year-old vines, seven feet apart. Prune from September [?] to March, leaving five canes to the vine; also summer prune by pinching every week a few inches above the bunches. For a trellis I use one or two stakes to the vine. Cultivate with a plow and hoe in April; these tools are the best for such work. 'Do not mulch. Have tried a great many varieties. Moore's Early and Norton's Virginia are the most successful here. Gather my grapes when ripe and sell to local dealers, receiving from two to three cents per pound; but do not think they pay. Have never sacked the fruit, as I consider it too great a task.

IsaAC M. TAYLOR, Richmond, Franklin county: I have fifteen vines, for family use, planted on light, sandy soil sloping to the southeast. The slope has a great deal to do with it; I would prefer an eastern. Set two-year-old vines. Prune in February, back to two or three buds on new wood; also summer prune some years. Cut back to within one or two joints of the fruit, to save it from mildew. My trellis is posts one rod apart and two No. 12 wires. Do not mulch. Have tried Concord and Dracut Amber; discarded the latter because of poor flavor. I would recommend Concord, as it does best in this locality. I sell in home market, receiving from two to three cents per pound. Have sacked my grapes to protect them from the chickens. It was a partial success. Several persons here are intending to do it to protect from bees.

David Brown, Richmond, Franklin county: I have a half acre of Concord grapes growing on red soil having a southern aspect; set eight feet apart. Cultivate with a cultivator. Prune in February. My trellis is of hedge posts and wire. I do not summer prune; it does n't pay. I have never bagged my grapes, and would not advise it, as it is not necessary. They are a paying crop.

William Cutter, Junction City, Geary county: I have one and one-half acres of grape-vines growing on land which is too sandy and has no clay subsoil. I think slope makes a difference, and would prefer a north or northwestern. Set No. 1 yearling vines, five by eight feet. Prune to three eyes or renew when possible; I do not summer prune enough. For a trellis I use poste and three wires. Till with a plow, cultivator, and hoe, which I consider best for the work; do not mulch. Have tried Admirable, Agawam, Aminia, Bacchus, Beauty, Bell, Berckman, Brayler, Brighton, Brilliant, Campbell (G. W.), Campbell's Early, Carman, Catawba, Centennial, Champion, Colrain, Concord, Delaware, Dinkel, Dracut Amber, Early Daisy, Early Concord, Etta, Elvira, Esther, Eumelan, Early Victor, Empire State, Green's Golden, Green Mountain, Goethe, Geneva, Golden Drop, Gold Coin, Hayes, Herbemont, Herman Guiger, Hilgard, Ives's Seedling, Jessica, Jewel, Jefferson, Keystone, Lutie, Lady Washington, Leader, Montifiero, Moyer, Moore's Early, Martha, Moore's Diamond, Munson's 88, Munson's 82, Mills, Merrimac, Mason's Seedling, Niagara, Nectar, Norton's Virginia, New Haven, Pocklington, Prentiss, Poughkeepsie Red, Prest Early, Peter Wylie, Perkins, Rockwood, Rommel, Red Eagle, Triumph, Telegraph, Ulster Prolific, Vergennes, Victoria, Worden, Wyoming Red, Woodruff Red. I have also tried many seedlings; one which is larger and sweeter than any other I have ever seen is now being tested in several states. I have discarded nearly all on account of feeble growth, inferior size, and because most of them ripen at the same time as the Concord; there is not difference enough in price 
to justify us in growing the many good varieties that require protection and other special treatment. I would recommend three-fourths Concord, Worden, Moore's Diamond, Woodruff Red, Catawba, a few Green Mountain and Delaware. Gather and market in eight- and ten-pound baskets; usually sell at home, receiving from one and one-half to three cents per pound. They do not pay me, but I would advise extensive planting, on a proper site having a clay subsoil. I have sacked the fruit to a limited extent; it is the only way to be sure of having a perfect bunch of grapes, as the birds and insects are so bad. We put up unfermented grape juice; boil it and bottle while hot; I guess it was good, for it was all drank while I was absent.

Jesse Royer, Gove, Gove county: I have 250 grape-vines growing on upland; a southeastern slope is preferable. Set two-year-old vines, eight feet apart. Prune in February, with a knife or shears. I do not trellis my grapes, as the wind is too strong for them. Till with a cultivator, which is the best tool for the work. I mulch my vines. I have tried only Concord, which I find best for this locality. We consume all of our grapes at home. I consider them a paying crop, and would advise extensive planting here. Have not sacked the fruit.

J. E. Springer, Gove, Gove county: I have fourteen grape-vines growing in black loam. I think the slope makes a great difference, and would prefer a northern or eastern. Set two-year-old vines, six feet apart. Prune in February and March. Cut off the "foxes" in summer. Have tried Pocklington, Worden, Martha, and Concord; have discarded Pocklington and Martha, as they are too tender and winter-kill. For this locality I recommend Concord, Worden, and Moore's Early. I do not consider them profitable, and would not advise extensive planting. I have sacked the fruit, and find it pays. My experience with grapes in this country is limited.

John E. Soderstrom, Gove, Gove county: I have 200 grape-vines, planted on poor, light bottom land. Set two-year-old vines, $8 \times 10$ feet. Prune in the spring; have also summer pruned, but it is not satisfactory. For a trellis, I use posts and wire; I shall use the canopy style recommended by Munson, of Texas, only that I am not going to build it so high. Till vines with a five-tooth cultivator. Do not mulch. Have tried Concord, Worden, and Diamond, and I would recommend them for this locality. I. have discarded none. Concord does best here. They are profitable on good soil, and I would advise extensive planting, if you have such soil. Have never sacked the fruit. All upland (here) is good soil for grapes, but the bottom lands along the Smoky river and Plum creek-on which I am located-is not good, as it gets too compact. There are some very profitable vineyards here and they promise to be a great success in this locality.

F. D. Turck, Hill City, Graham county: I have a few grape-vines, planted on bottom land. A northern slope is best, unless on bottom land, which ought to be level. Set two-year-old vines, $8 \times 16 \frac{1}{2}$ feet. Prune during winter; also, in summer, around the base of vines. My trellis is posts and three wires. Have used barn-yard litter between the rows. Have tried Concord and other varieties. I would recommend Concord for this locality, as it seems to be the hardiest. They bring a good price here, but I have never had any for market. I would not advise extensive planting. Have never sacked the fruit, but am going to this year. The grasshoppers are our worst enemy here, as they cut the stems and the grapes drop off. 
Mrs. I. M. VAN Doran, Leland, Graham county: I have fourteen grapevines; set, at one year of age, eight feet apart. I mulch my vines. Have tried only Concord; just lately set out, so cannot give experience.

J. P. Emery, Cimarron, Gray county: I have 100 grape-vines, planted on black loam. Set two-year-old vines, eight feet apart. Prune in February to two buds on the previous year's growth. Do not summer prune. Tie my vines up to small cedar posts. Till with a nine-hoe cultivator; I prefer a small cultivator. I do not mulch. Have tried the Concord and Delaware; both are good bearers. I would recommend these varieties for this locality. Use all the fruit at home. They are a paying crop, and I would advise extensive planting. Have never bagged the fruit. My grapes began bearing the first year after setting, and have borne well for the past four years.

D. M. Trueblood, Tribune, Greeley county: I have just finished setting out a few grape-vines - my first planting - and I believe they will do all right here if irrigated and properly cared for. There are a few growing about town in bush form, not trellised; they bear some.

J. M. Hinshaw, Eureka, Greenwood county: I have one acre of grape-vines growing on upland. Set yearling vines, $6 \times 8$ feet. Prune in the spring by cutting back, leaving three buds of last year's growth. My trellis is three wires on posts. Till them shallow and often, with a one-horsecultivator; do not mulch. Have tried Concord, Worden, Ives, Dracut A mber, Pocklington, Goethe, Moore's Early, Elvira, Catawba, Lutie, Salem, Agawam, Perkins, and Wyoming Red; have discarded none. I would recommend Concord, Worden, Ives, Dracut Amber, Lutie, Pocklington, and Goethe, which do best here. Gather in market baskets and sell at home. They are not very profitable, and I would not advise extensive planting here. Have never sacked the fruit.

G. M. Munger, Eureka, Greenwood county: I have 500 grape-vines, planted on upland prairie sloping to the east. My varieties are: Concord, Moore's Early, Pocklington, and others. Would recommend Concord, Moore's Early, and Martha. I prefer one-year-old vines, set eight feet each way. I cultivate like corn. Prune in late winter and early summer. My trellis is of wire. I do not bag my grapes. Turkeys, blackbirds and neighbors' dogs help gather our grapes for us. We have a few left. They are a paying crop.

Geo. W. Reiter, Fall River, Greenwood county: I have about twenty grape vines, planted on sandy upland loam. Set yearling vines, eight feet apart. Prune in February. My trellis is posts and smooth wires. I cultivate while the vines are small; then keep the weeds hoed out. I mulched my vines one year, but it was a wet season and the grapes mildewed. I never tried it again. Have tried only Concord. Have never sacked the fruit. Raise them for family use only.

W. H. Wiggins, Lapland, Greenwood county : I have 1000 grape-vines growing on an eastern slope, which $I$ think is preferable. Plant two-year-old vines, $6 \times 10$ feet. Prune in March, and during the summer I take off any vines which hang down. I use a hedge post at each vine, with wires stretched along the rows. Cultivate with a plow and hoe; shallow culture is best. Do not mulch. Have tried Concord, which I would recommend. Gather in twenty-pound baskets and sell at home, receiving two cents per pound. They are a profitable, paying crop, but I would not advise extensive planting here. Have never sacked the fruit, as I do n't think it would pay.

JoHn BaILey, Harper, Harper county: I prefer one-year-old vines, set six by 
twelve feet. Till with a five-shovel cultivator; prune in the spring. I do not summer prune. Never bagged any grapes. Market at home; the price is generally one and a half to two cents per pound. I consider them a paying crop.

W. E. Blackburn, Anthony, Harper county: I have one-third of an acre of grape-vines, planted on brown, sandy loam. Set one-year-old vines; Delaware four by six feet, and stronger varieties ten by ten feet. Prune to two arms early in February; I also prune by breaking off buds that are not wanted as soon as in bloom, and later pinch off the ends of the shoots when the fruit is well set. Have tried Concord, Delaware, Cottage, Worden, Moyer, Herbemont, Norton's Virginia, Cynthiana, Niagara, Martha, Moore's Diamond, Goethe, Early Ohio, and several others that have not fruited yet. Have discarded Concord and Cottage for poor quality, and Herbemont because our hot weather in August forced ripening and impaired quality. Those best for this locality are Delaware, Moyer, Niagara, Goethe, Martha, Diamond, Norton's Virginia, Worden, and Early Ohio. Think Munson's post-oak hybrids will do well here, and I have a dozen or more varieties under experiment. They are a paying crop, and I would advise extensive planting for shipping, if near a railroad. Have sacked the fruit, but it do n't pay. The birds pick through the sacks. The best plan is to train the leaf growth so. as to conceal the fruit.

Edward Chatelaine, Harper, Harper county: I have 200 grape-vines growing in sandy loam. I think an eastern slope preferable, and natural protection an advantage. Plant one-year-old vines started from mother vines [layers?]. Cuttings make poor vines. Set them $4 \times 6$ feet. Prune closely any time after the leaves drop, cutting out all old canes, if possible, leaving all of the new growth. Do not summer prune, as the shade is all wanted to protect the fruit from the hot sun. Till shallow, with a five-tooth cultivator and hoe. Do not mulch. Have tried Concord, Rogers's Hybrid, Delaware, Moore's Early, Champion, Clinton, Isabella, Martha, and Niagara. Have discarded Champion, Martha, and Clinton, because of poor quality ; and Niagara, because of inclination to burn. I would recommend Concord, Rogers's Hybrid, and Delaware, as they are the most satisfactory here. The surplus, after the family gets what it wants, is sold for three cents per pound. They would be a paying crop at this price; at less they would not. I would advise planting for the family and not for commercial purposes. Have never sacked the fruit, as I do n't think it would pay.

J. C. Curran, Curran, Harper county: I have 1000 grape-vines growing on land that is damp-subirrigated; slope makes no difference. Prune after the leaves fall by cutting away all dead wood; I prune during the summer when I can, as soon as the grapes are set. Till with a five-tooth cultivator; a hoe is the best tool; do not mulch. Have tried Concord, Niagara, Agawam, Champion, Hartford Prolific, Moore's Early, Pocklington, and several others which do well; have discarded none. Niagara, Catawba, Concord, Missouri Reisling and Agawam do well here. Sell my grapes for two to three cents per pound. They are profitable, and I would advise extensive planting if your land is suitable. Have sacked the fruit, but it did not pay; the wind whips the sacks, and the rain spoils them; they get off. All kinds of grapes, excepting the Muscove, do well here. Plant them eight feet apart, and use a trellis four feet wide. Do not mulch, as in this climate the roots come up between the mulching and the lower ones disappear, and the vineyard is ruined; a new one can be grown before this will recover. Cultivate after each rain; keep it raked up loose, so as to form a dust mulch. You can raise grapes by the ton in this county. The enemies of grapes are poultry and birds. We provide homes for the birds but do not pro- 
vide food for them; the mulberries and cherries are all gone when the dry weather comes on, and the birds must eat the grapes or starve. To kill them is cruel and only destroys our best friends. There is a remedy for this difficulty that is cheap and sure; it is, plant wild cherries, elderberries, black haws and wild grapes some distance from your vineyard, which will furnish food for them, and they will not trouble your grapes.

V. B. Jones, Syracuse, Hamilton county: I have about a dozen grape-vines, set on dark loam. I planted one- and two-year-old vines, six feet apart. Cultitivate with a plow and Acme harrow, the same as corn. Do not mulch. The grasshoppers prune my vines for me. Have tried Concord and Worden. They are not profitable, and I would not advise extensive planting here. Have never sacked the fruit. I set out about an acre several years ago and irrigated them once or twice, and they grew pretty well till the latter part of the summer, when the grasshoppers stripped them of their foliage. The following year we failed to get water to irrigate with, and the grasshoppers about finished them. I have about a dozen of them left which I have just transplanted to a place where I can irrigate them,

A. J. Saltzman, Burrton, Harvey county: Have 600 grape-vines, on a southern slope; mostly Concord, with a few Moore's Early, Champion, Agawam, Elvira, and Lindley. I would recommend for all purposes Concord, as it is hard to beat. Champion is good for early. Agawam and Lindley are among the best for table use. I plant first-class one-year-old vines, in rows eight feet apart, the vines six feet in the rows. Cultivate with five-tooth cultivator. In February I prune back to two or three buds; also prune some in summer, as it throws the strength to the fruit. My trellis is posts and wire. Have never bagged grapes, but think it might do in a small way, but otherwise is too expensive. I cut the stems with a knife and pack into baskets at once, using ten-and twenty-pound baskets. Market north and west of here, receiving from $\$ 80$ to $\$ 150$ per acre for them. I consider them a paying crop.

David Lehman, Halstead, Harvey county: Have 160 Concord grape-vines growing on sandy loam with an eastern slope. Planted one-year-old vines, $4 \times 6$ feet. Till deeply in spring with a cultivator, and more shallow later. Prune, leaving three or four one-year-old arms and one or two stubs; also summer prune, to check the growth of the vine and increase the growth of the fruit. I think posts and wires make the best trellis.

William J. Clark, Halstead, Harvey county: I have seventy-five grape-vines, planted on sandy loam which slopes to the southwest, but I do not think this desirable, as they get too much sun. Set two-year-old vines, eight feet apart. Prune in February by cutting out old wood, also all new, excepting about four new vines. Do not summer prune. I use a cultivator and harrow early; then cover with a heavy mulch of coarse stable litter or stalks. Concord is the only variety I have tried. Have never marketed any; they are a sure crop here, but the prices are low; I would advise planting extensively if we could get better prices. I have sacked my grapes, but the birds pick holes in the sacks. It does not pay.

Henry Chateles, Newton, Harvey county: I have fifteen grape-vines growing on black loam having a fifteen-inch, yellow-clay subsoil. I think slope makes a difference; would prefer a southeastern. Set two-year-old vines, $8 \times 8$ feet; prune during winter to two or three buds. For a trellis I use Osage orange stakes. Cultivate shallow - three inches; a hoe is best for small patches; I 
mulch my vines. Have tried Concord, Martha, Empire State, Niagara, Worden, and Moore's Early; have discarded all but Concord, as they either die or wither; I would recommend the Concord for this locality. The birds gather most of the fruit. They would pay if one had ten or more acres, but would not advise extensive planting, as they are too cheap-two and one-half cents per pound. Have never sacked the fruit. The moles are quite destructive here; they get at the roots during winter and kill them.

P. NABB (reported by C. A. Seaman), Sedgwick, Harvey county: Mr. Nabb has one acre of grape-vines growing on a clay side-hill. He prefers a southwestern slope, as he thinks it improves the quality; sets two-year-old vines, $8 \times 10$ feet; prunes to two eyes in February; uses posts and wires for a trellis; tills his vines with a five-shovel cultivator; does not mulch. He has Concord, Salem, Delaware, Moore's Early, Niagara, and Clinton, and is best satisfied with Concord and recommends it for that locality. Cuts his grapes from the vines, and places them directly into the baskets in which they are marketed; sells at home, for two cents per pound. He considers them profitable, but would not adrise extensive planting in his locality. He has never used sacks, but says the birds are so very bad that he must do something to protect the fruit.

C. Bastian, Wittrup, Hodgeman county: I have forty-two grape-vines, set on one foot of black loam having a yellow subsoil which slopes to the northeast.' My varieties are thirty Concord and twelve Moore's Early. I prefer one-year-old' vines, set eight feet apart. Cultivate my vines one year, then mulch; summer prune, letting only two canes grow; pinch suckers once a week. Have never bagged my grapes. I think they are a paying crop in western Kansas.

Joнn Vetter, Santa Fe, Haskell county: I have 400 grape-vines, planted on upland, which would be better if a little sandy. Set one-year-old vines, five feet apart. Prune ten buds to the rib. For a trellis I use posts and wires, to which I tie the vines. Till them with a plow, but a cultivator is the best implement for the work. Do not mulch. Have tried only Concord, which I would recommend, as it does well in this locality. Market in local market, receiving three cents per pound. I consider them a paying crop. Have never sacked the fruit.

F. W. Dixon, Holton, Jackson county: I have 1000 grape-vines, on a southern slope. They are Moore's Early, Concord, Worden, and Elvira. Would recommend this list. Have experimentally tried Niagara, Pocklington, Wyoming Red, and Hartford. Hartford and Pocklington are good. I plant oneyear-old vines, $8 \times 10$ feet. Till with an Acmecultivator harrow. Prune in early March, cutting new growth back to two or three buds, on the arm-and-spur system; never summer prune, because it costs money and is of no particular benefit. I think posts and three wires make the best trellis. Sometimes I bag some, but it will not pay. Pick in eight-pound baskets, ready for market. Market at home mostly, realizing fifty dollars net per acre. They are a paying crop. Have put up unfermented grape juice. We press the juice out, bring to a boil, skim, sweeten to taste, and seal in bottles.

F. L. Osborn, Soldier, Jackson county: I have 700 grape-vines growing on an eastern slope with black loam soil. My varieties are Concord, Moore's Early, and Worden; I recommend Concord and Moore's Early. I have several varieties' that I do not know the name of, but all of them are doing well. I prefer twoyear-old vines, set eight by ten feet. I cultivate shallow but thorough; weeds should not be allowed to grow up through vines; they cause rot. I prune in February or March; trim the new wood to two buds; my trellis is of wire, which. 
is cheap, and creates less shade and take less room than wood trellises. I summer prune if the vines are very thrifty; the fruit develops better and ripens evener. I have never bagged any and would not advise it, as I do not think the price of fruit would justify it. I gather by cutting with a knife, and pack in baskets and market at home, realizing three cents per pound, for one and onehalf tons. I consider them a paying crop. Grapes may be profitably grown in Jackson county if the vines are properly cared for, but through neglect sixty per cent. of the vines here have died during the past. Pruning is but little understood by Kansans here, and, unless directed by a German or some one of vineyard experience, the vines are not cut back sufficiently, causing them to overbear, which is very hard on them, killing them in two or three years. Exhausted by overproduction and robbed by weeds, a hard winter easily kills them. Some mulch to keep down weeds, but this proved unsatisfactory with us, as it induces the roots to grow near the top of the ground, making them hard to cultivate and easily injured by dry weather.

J.W. Wrlliams, Holton, Jackson county: I have seventeen vines, planted on prairie upland having a southern slope. Set one- and two-year-old vines, $8 \times 10$ feet apart. I prune in December or February, by cutting back last year's grow th to two or three buds. My trellis is hard-wood stakes, six to eight feet high. I till them with a garden rake, but if I had many would use a plow. Do not mulch. Prune the green shoots during the summer by pinching back to within two buds of the bunches. I have tried Concord, Pocklington, Moore's Early, Wyoming Red, Martha, Norton's Virginia, Delaware, Niagara, Clinton, Catawba, and Isabella. Of these, I have discarded all excepting Concord, Wyoming Red, and Moore's Early, because it does not pay to raise so many varieties. Moore's Early and Concord do best here. Gather and market in grape baskets, receiving two cents per pound. They do not pay, and I would not advise planting them largely here. I have tried sacking my grapes, and find that it pays; have bagged one bunch on a limb where there were two or three, and found that the unbagged bunches rotted, while the bagged bunch was not affected. Have put up unfermented grape juice; take ripe grapes, strip from stems, put in to a vessel, boil to a pulp, press through a colander, then strain and put juice on to boil again, adding sugar to fairly sweeten; bottle while hot and seal up.

Jołn M. BACON, Soldier, Jackson county: I have 125 grape-vines, planted on upland prairie; an eastern or southern slope is preferable; set one-year-old vines, $8 \times 10$ feet; prune back to two or three buds in the fall, and cut all the long shoots on the sides of the rows during summer; use a wire trellis; cultivate with a one-horse double-shovel plow and a hoe; do not mulch my vines; have tried Concord, Moore's Early, Worden, Salem, Agawam, A ugust Giant, Jewel, Jefferson, Niagara, Elvira, and several others; have discarded the Jewel and Elvira; the former is small and almost tasteless, and the latter is no better than a groundcherry; all varieties do well here, but Worden best, with August Giant a close second; I would recommend for planting here Worden, Moore's Early, Salem, August Giant, Jefferson, and Agawam; gather generally in sixteen-pound baskets; sell at home, receiving three cents per pound; they are a profitable crop, but I would not advise extensive planting; have never sacked the fruit. We put ap unfermented grape juice; boil the grapes, and as soon as cool squeeze out the juice; add one pound of sugar to every half-gallon of juice and bring to a boil; skim, and seal in fruit-cans.

J.W. Curry, Dunavant, Jefferson county: I have fifty vines, planted on heavy soil. I think a north slope best. Set two-year-old vines, eight feet apart. 
Prune in March, to one or two of last year buds; sometimes prune during wet weather in the summer. My trellis is of posts and wire. Till by plowing and hoeing in the spring and then mulch. I have tried Concord, Delaware, and a white grape; the Concord does best and I would recommend it for this locality. It pays to raise them for home use, but I would not advise planting them extensively. Have never tried bagging the fruit.

Lou Mrlcer, Perry, Jefferson county: I have about 300 grape-vines, planted on a northeastern slope, with a gray loam soil and a clay subsoil. My variety is the Clinton; I have one variety which I am testing experimentally. I plant yearling vines, eight feet in the row, and cultivate with plow and hoe; prune in the winter by cutting back to two or three buds. Have a wire trellis; do not prune in the summer. Have never bagged any ; use all the fruit at home; pick them as wanted. I consider them a paying crop for home use.

H. R. Roberts, Perry, Jefferson county: Have about 100 grape-vines growing on upland of a dark loam with a clay subsoil, sloping to the northwest. My varieties are Concord, Moore's Early, Niagara, and Worden. Would recommend Moore's Early, Niagara, and Concord. I plant one year-old vines, ten by ten feet; cultivate with a corn cultivator and hoe; prune early in March to three buds; I do not summer prune for lack of time; probably it would not pay. My trellis is made of barbed wire, which I think is best in this windy country, as the wind cannot slide the vines along on this as it can on smooth wire, when blowing lengthwise of the trellis. Have never bagged any. Gather in eight- or ten-pound baskets - I prefer eight-pound - and market as near by as possible. Do not know how much I realize from my grapes, but they are not very profitable.

M. M. GABorsch, Salem, Jewell county: I have fifty grape-vines; a south slope is preferable; planted two-year-old vines, six feet apart. Prune in the fall. I use a trellis of four-foot posts and smooth wire. Cultivate with a one-horse plow; I also mulch my vines. Have tried Concord and Virginia Seedling, but discarded the latter because it did not pay; would recommend Concord only for this locality. Cut my grapes from the vines with a knife. I would advise planting extensively, as they are a paying crop. Have never tried sacking my grapes. I have had ten years' experience with grapes; use to raise them in Illinois, and think they would pay in Kansas, if given proper attention.

Henry Rhoades, Gardner, Johnson county: I have about fifty vines, mostly Concord. Have put up unfermented grape juice; I heat the juice, and seal while hot.

E. P. Dikhl, Olathe, Johnson county: Have 300 grape-vines growing on black loam sloping slightly to the south. Have tested Concord, Herbemont, Pocklington, Delaware, and Clinton; have discarded Herbemont, Clinton and Pocklington as not profitable; would recommend Moore's Early and Delaware, with which I have had very good success. Plant one-year-old vines, eight feet apart; cultivate with a one-horse cultivator and hoe, more thoroughly in dry seasons, but in wet seasons let the weeds grow, which will prevent the rot. Prune closely in February; then again in summer, to improve the fruit. I have a wire trellis. Bag my grapes; and would advise it; it protects the fruit from bees and insects. Gather in baskets and market at Olathe, realizing from twenty to thirty-five dollars per acre. They are not a paying crop. Have put up unfermented grape juice; boil the juice, skim, put in bottles, and seal tightly.

J. C. Beckley, Spring Hill, Johnson county: I have 134 grape-vines growing on mulatto soil sloping slightly to the west. My varieties are: Concord, 
Delaware, Moore's Early, Niagara, Worden, Agawam, Ives, Dracut Amber, Duchess, and some others (names lost). I would recommend Concord, Moore's Early, Niagara, and Worden, also Delaware; but the latter must be protected in winter, as it is somewhat tender, but bears well every year. I have experimented with Wyoming Red, Catawba, and Goethe, and find them fairly good. I prefer one-year-old vines, set eight feet apart in the row, and the rows ten feet apart. I cultivate with a team and plow. Prune in February with pruning shears. My trellises are good hedge posts and two No. 9 wires. Do very little summer pruning, as it does n't pay for the labor. Have never bagged my grapes, and would not advise it, as I do not think it would pay here. Market my grapes in ten-pound grape baskets, mostly at home. Sometimes I ship them South. I realize about seventy-five dollars per acre. I consider them profitable. The soil should be of ordinary fertility, such as would raise a fair corn crop. Rich, loamy lands are objectionable. Soils retaining a surplus of water should have drainage both of the surface and subsoil. High lands are preferable, as such of ten escape late spring frosts, and receive a circulation of air among the vines, which is very necessary to the grape, and will to some extent avert the tendency to rot. On such lands the wood matures best, and the fruit is of fine quality. Windbreaks are detrimental, because the grape must have all the light and air it can get, in order to be of the very best quality. I prefer a western slope; a southern slope is too dry and hot. A northern or eastern slope is not good, as it affects the flavor and quality of the fruit. The grape does best where the ground is cultivated and kept clean of weeds and trash. The new wood, or last year's growth, should be cut back to one or two eyes where the vine is over three years' old and well tied up to the trellis. As the fruit will keep but a short time, it should be packed in the common grape baskets and marketed as soon as ripe. Before packing, all defective berries should be removed and the clusters placed with the stem downward. If for a distant market, they must be picked before fully ripe.

C. H. Longstreth, Lakin, Kearny county: I have 150 vines, planted on level land; they are Concord, Worden, and Niagara. I would recommend these varieties. I prefer good one-year-old vines, planted in rows eight feet apart, eight to ten feet in the row. Cultivate shallow, in the early part of the season; prune closely during the winter, when there is no frost; my trellis is made of posts and three wires-two, four and six feet from the ground. I do not prune in the summer, as I do not think it beneficial to the growth of fruit. Have never bagged any. Market my grapes at home, and consider them profitable.

W. R. Coleman, Kingman, Kingman county: I have five acres of grapes, planted on black, sandy loam. A northeast slope is preferable. Set good, strong two-year-old vines, eight feet each way. Prune from January 1 to March 15 to spurs, on the renewal plan. I also prune three times during summer, leaving three leaves beyond the last bunch on each cane; last pruning not later than July 1. I use a trellis of good posts, twenty-four feet apart, and a single No. 12 wire. Cultivate in March with a turning plow, and the remainder of the season with a one-horse, five-shovel cultivator. Do not stir deep enough to tear the roots. I would prefer a one-horse disk, if I could get it. Do not mulch, as it entices the roots too near the surface. I have tried thirty or forty varieties, and have discarded all but six of the most profitable. Those which do best and that I would recommend are: Moore's Early, Concord, Niagara, Catawba, and Lady Washington. Market in ten- and twenty-pound baskets; sell in local market, re- 
ceiving an average of two and one half cents per pound for the past ten years. They are a profitable crop, but I would not advise extensive planting. Have never tried sacking the fruit.

W. J. Brown, Greensburg, Kiowa county: I have 100 grape-vines growing on black, sandy loam, which have been set fourteen yeare. A northeast slope is preferable. Set out one-year-old vines, $8 \times 15$ feet. Prune in November to two and three buds of last year's growth. For a trellis, I use two slats on a post five feet high. Till them with a cultivator and harrow; a double-shovel cultivator and a one-horse harrow are the best implements for this work. I manure my vines some. Have tried Concord, Delaware, Martha, and Goethe; discarded the Martha and Goethe, as they would not stand the climate; the soil is so porous they are destroyed by winter freezing. I would recommend Concord for this locality, as it does best here. I pickle a good many of my grapes. They are profitable to a limited extent, but I would not advise extensive planting here. Have never sacked the fruit, as our market would not warrant it. We put up unfermented grape juice like we can fruit.

A. D. Einsel, Greensburg, Kiowa county: Have about a dozen vines, planted on sandy soil. Set $10 \times 10$ feet. Prune back to two eyes. Use stakes for trellis. Cultivate by spading around the vine in the spring. I mulch my vines. Have tried Concord only. Grow only for home use. Planted a vineyard of 500 vines when the land was new, but all are dead excepting nine; did not attend them as I should; think they would do better now.

D. E. Winters, Haviland, Kiowa county: Almost any kind of land will grow grapes if well cared for; my land has a northern slope; varieties are Worden and Concord, which latter does best; 1 prefer two-year-old vines, set twelve feet apart; till with a cultivator and boe; prune in the spring; my trellis has three wires; I do not summer prune, as I think it retards the development of the fruit; have never bagged my grapes; I think it too much trouble; cut my grapes with scissors and market in baskets at home; I think they pay; I think grapes can be grown for profit in this county if properly set and started right; they will probably need a little water the first year and in July of second year, but the main thing is to cultivate and keep all-not part-of the weeds out; allow no sod nearer than eight feet; prune closely in spring and keep vines as near to the ground as possible; all the grape-vines in the county that I know of are fine where cared for, and yield abundantly, but there are only a few vines; a few men have a hundred or more, but most have ten or twenty; I have set only twelve so far; shall set more next year; they will be half Worden and half Concord.

Charles Harrington, Altamont, Labette county: Have 100 grape-vines growing on level land. Varieties tested are Concord, Clinton, Dracut Amber, Worden, Moore's Early, etc. Have discarded Clinton, as it rots too badly. Would recommend Moore's Early, Dracut Amber, Worden, Concord, and Moore's Diamond. Am testing experimentally Brighton, Goethe, Pocklington, Campbell's Early, Niagara, Early Ohio, Elvira, and Delaware; these have not yet come into bearing. Plant one- or two-year-old vines, eight by ten feet; till with a fivetooth-cultivator. Prune in February to two buds with pruning shears; do not summer prune, as the sun burns the fruit. I think a trellis of posts and wires is best. Do not bag any, but would advise it, as the bags protect the fruit from disease, insects, and birds, and it can hang on the vines much longer. Gather with pruning sheers; market at home and in Colorado, in eight-pound baskets. I think the grape a moderately paying crop. 
S. M. Beeson, Angola, Labette county: I have fifty grape-vines, planted on heavy loam having a clay subsoil. Set one-year-old vines, four by eight feet. Prune any time during the winter when the sap is out of the vines; cut out all old growth, leaving nothing but the previous year's growth. Do not summer prune. Use a trellis made of Osage orange posts and wire. Till with a cultivator; think a five-tooth-cultivator best. Tried mulching my vines and lost them. Have tried Concord; that is the only variety grown here. Would recommend Dracut Amber, Champion, Moore's Early, Worden, Niagara, Wyoming Red, and Concord. Use all of our grapes at home; do not think they would pay for commercial purposes, as we are too far from market. I would not advise extensive planting here. Have never sacked my grapes, as they are not troubled with anything; but think it would pay for home use. Twelve years ago I had fine bearing vines mulched with straw, and in three years they were all dead. Some use corn-cobs for mulching with good results. My experience is that shallow but thorough cultivation is best.

Chas. A. Gordon, Chetopa, Labette county: I have one-half acre of grapevines, planted on clay and sandy land. I think slope makes some difference, and would prefer any slope but north. Set yearling vines six feet apart. Prune in November or January to two buds; also, summer prune until the grapes get their growth; then let a few shoots grow. Tie my vines to a single stake. Shallow, frequent tillage, with garden cultivator, is best. Mulch with well-pulverized earth. Have tried Concord and one other variety. We receive two cents per pound for the fruit, but they are not a very profitable crop. Would not advise extensive planting. Have tried sacking, on a small scale; it protects the fruit very well, but I do n't think it pays. We have put up unfermented grape juice; we Pasteurize it.

R. DeGarmo, Oswego, Labette county: I have about 100 grape-vines growing on black limestone soil. Set one- and two-year-old vines, $6 \times 8$ feet. Prune, during winter, by cutting away all surplus wood; during summer, prune away all beyond the third bunch. Use a trellis five feet high. Till with a cultivator and hoe. I consider shallow cultivation best. Do not mulch. Have tried Concord, Moore's Early, Moore's Diamond, Goethe, Pocklington, and two or three white grapes. Have discarded Moore's Early, or, rather, will soon; Clinton because it is too small and sour, and Diana, which is a good grape, but too tender. I would recommend Concord, Moore's Diamond, Goethe, and Pocklington. We use all of our grapes at home. I would not advise extensive planting, as they are so badly affected with rot. I have sacked the fruit for several years, and think it pays, as they last longer in the fall; but I did not always get them on soon enough to avoid rot.

D. E. Bradstreet, Dighton, Lane county: Have hadififty grape-vines, planted on bottom land. I set yearling vines, seven feet apart. Pruneduring February, with a knife. Use a smooth-wire trellis. Cultivate my grapes with hoe to keep the weeds down. A cultivator is a good tool for this use. I mulch my vines to prevent them from budding too early. Have tried only Concord; I consider them a paying crop, but would not advise extensive planting. Have never bagged the fruit. They were a paying crop before the grasshoppers stripped and killed them. I raised turkeys to kill the grasshoppers, but the turkeys ate the grapes when half grown.

JacoB Graves, Healy, Lane county: Have one and one-half acres of grapes, set on a sandy loam bottom. Planted one-year-old vines, $6 \times 8$ feet. Prune dur- 
ing the winter when not frozen; cut back one-half of last year's growth; during summer I prune all the new growth from the ground. Use a wire trellis. Till with a cultivator and hoe. I think a cultivator and stirring plow are the best tools for this work; they should be cultivated often; shallow cultivation is best. I do not mulch, but think it would be a good thing here, and I certainly would if I had the mulching. Have tried Concord, Clinton, Delaware, and Moore's Early; have discarded the Clinton and Moore's Early; the Clinton is no good, and Moore's Early winter-kills; would recommend Concord, as it does best here. Gather my grapes in baskets and sell at home and in near-by towns, receiving two and one-half cents cents per pound. They are a paying crop, and would advise extensive planting, if cultivated well. Have never sacked the fruit.

E. GAISER, Lansing, Leavenworth county : I have 600 grape-vines growing on rich soil, having a southeastern aspect. I spray them four times a year. My varieties are Concord, Elvira, Moore's Diamond, and Niagara; have tried and discarded Elvira, because it tasted green; I would recommend Concord, Cynthiana, and Delaware. I prefer two-year-old vines, set $8 \times 8$ feet. Cultivate with a diamond plow. Prune with grape shears in February; my trellis is wire; I never summer prune; I do n't have time. Have never bagged any and do not advise it, as I think it too much work for the benefit derived. Gather the grapes in baskets and use them all at home; we get 5000 pounds per acre. I do not consider them a paying crop.

Dr. J. Stayman, Leavenworth, Leavenworth county: We have been growing grapes successfully in Kansas for the last forty years, having had a previous knowledge of the business, as my father planted five acres of vineyard about eighty years ago, when grape culture was in its infancy. Any kind of soil that will grow wheat or corn will grow grapes. A dry, calcareous soil is best. It is not so much in the soil as in the location. There is a difference of twenty-five per cent. in the saccharine matter of the grape on the same kind of soil, not two two miles apart, due to the location. This makes a difference of twenty five per cent. in the quality of the grapes, as the quality depends upon the amount of sugar the grape contains. This difference is one-half pound of sugar to every fifteen pounds of grapes. A gentle eastern or southeastern slope is the most desirable; but it is not so much in the slope as elevation and latitude of the particular vineyard. High hills and bluffs above valleys and ravines are much the best. The value of hills is in proportion to their height and proximity to bluffs. We have tried every native grape of apparent value yet introduced, besides numerous hybrids, crosses, and wild varieties. Over 200 and more were discarded as being worthless in quality, tender, or not productive.

Following are the best: Alaska, Barry, Beacon, Brighton, Catawba, Crisholm's No. 9, Concord, Cynthiana, Delaware, Darwin, Dearoba, Diamond, Dracut Amber, Eclipse, Early Victor, Elvira, Farrell, Goethe, Pocklington, Green Mountain, Herman, Ideal, Ives, Jewel, Magnate, Marsala, Mary Mark, Moore's Early, Massasoit, Niagara, Norfolk, Norton's Virginia, Osage, Omego, Ozark, Paragon, Pawnee, Primate, Standard, Supreme, White Beauty, White Imperial, Woodruff, Worden. I would recommend the Alaska, the finest very late grape known, hardy, healthy, and very productive; large bunch and berry. Eclipsethe largest white and best in quality, but not very compact in bunch. Concord - one of the most reliable. Diamond-large bunch and berry, but sometimes rots badly; not as hardy as some others. Delaware - the standard of excellence. Darwin - seedling of Delaware, equal in quality but larger in bunch and berry, and a stronger grower. Cynthiana - the best black wine grape known. Mag- 
nate - a large white Concord, better in quality and very productive. Moore's Early - a large, early, market grape. Ideal - the finest large red grape known. Paragon - the finest black grape of its season. Osage - the largest black grape we have, better and earlier than Concord. Ozark - the wonder among native grapes. Supreme-earliest black grape grown, and fine. Herman - the best late grape for white wine. Worden - about like Concord but a few days earlier. White Beauty - the finest white grape grown. White Imperial - an improvement in quality over the above, but not so large in berry. Marsala - the besf jelly grape except Crisholm's No. 9.

This list has been thoroughly tested experimentally, and found to be the best and most valuable, and is adapted to the various purposes grapes are grown for. I plant good, strong one- or two-year-old vines, shorten in the top and roots, and set not over eight.inches deep, either in the fall or early spring. Set all strong growers, like the Concord, $8 \times 8$ feet, but those like Delaware, four feet apart in the row and the rows six feet apart. We plow the vineyard in the spring, with a one-horse turning plow, throwing the soil from the vines, and in a short time return this soil, and afterwards cultivate with a Planet Jr. cultivator throughout the season. Hoe under the vines to keep the ground clear of weeds. The vines can be pruned from November until they begin to bleed in the spring, about the 1st or 15th of March, owing to the season. We prefer February and up to the time the vines do not bleed as the best; if it is done in the fall or before hard freezing weather, the vines will be more or less injured and the work will have to be practically done over. If vines are pruned after severe winter weather is over, we can leave just the number of canes and length needed without going over them the second time, while if done very early we will have to allow for what might be injured by the cold weather. We prune on the renewal system, starting the canes about a foot or so from the ground from a spur left there from renewal canes each season and train up two or more canes each season for bearing the next. These bearing canes should never start from the ground as suckers. In other words the suckers should be removed from the vines as soon as possible and kept off. A full-bearing vine, like Concord, may be pruned with four canes, twenty inches long, trained on a trellis, and four other canes to be grown from spurs to fill their places the season after, and so continue the pruning year after year. No exact rule can be given, for upon the strength of the vines depends the amount of wood that should be left on a vine in pruning.

I have a three-wire trellis; train the bearing wood on the lower two wires and the new wood for bearing the following season on the top wire. I never summer prune, unless it is to prepare a bunch for exhibition. It is an injury to pinch or summer prune. A very rampant cane may be pinched; so may suckers be pruned off; but otherwise the less the better. I cut the bunches of grapes from the vines with a knife and pack in about eight-pound baskets. Market in Leavenworth, generally receiving one and one-half to two cents per pound. Some seasons they are a paying crop, but others they realize little on account of rot. They are, however, as good a paying crop as any other fruit, but they require care to keep in paying condition. It requires care, labor and study to keep a vineyard as it should be; and it also requires experience to know what to plant for profit. We put up more or less unfermented grape juice every year. To properly do this, the grapes should be fully ripe and at their best, all imperfect and diseased berries picked off ; then run them through a mill to crush the berries and thus press out the juice at once. Place the juice in a vessel and let stand about eight or ten hours to settle. It is best to do this work on a rather cold day, as there is danger of the grapes starting to ferment while settling. 
After it is somewhat settled draw off as clear as you can apd put it in a kettle to boil, or rather bring it to the boiling-point and skim off any scum that arises. Have your bottles ready, scalded out clean and standing in hot water. As soon as the juice commences to boil, bottle at once; fill but one bottle at a time. Cork tightly by driving in good velvet corks, and seal. If this is done properly, and the juice placed in a cellar in the dark, it will keep for years.

J. Weidman, Lincoln, Lincoln county: Have three acres of grapes, planted on sandy soil with a clay subsoil having a west-northwest slope (would prefer an eastern slope). Would recommend Concord, Elvira, Worden, Catawba, Dracut Amber, Noah, Telegraph, Early Victor, Missouri Reisling, Cythiana, and Champion. Varieties tested experimentally are Niagara, Goethe, Northern Muscadine, Perkins, and three different very late seedlings of my own which are very fruitful and thrifty. Goethe and Niagara are not hardy here. Plant strong, oneyear-old vines, seven feet in the row, and the rows nine feet apart. Cultivate with stirring-plow in the spring, and after that with a one-horse cultivator; use the hoe in the rows twice during the season. Prune in April [?], or, when the weather will permit, in the spring. My trellis is of posts, with two or three No. 11 galvanized wires. I prune my vines during the summer by pinching out all canes not needed for next year's wood; also cut or pinch off near the last bunch before blooming - it makes the fruit perfect and easier to gather; too many leaves smother the fruit more or less. Bagging grapes is too slow work. Market $m y$ fruit in the vineyard and in near-by towns. I get about three tons per acre in good seasons. They are a paying crop when taken care of, as they sell at three cents per pound.

MaRTin Moss, Lincoln, Lincoln county: I have one-half acre of grape-vines growing on sandy soil. I prefer a northeast slope. Set yearling vines, eight feet apart. Prune in February to one bud on each spur of the main canes; have never summer pruned, but think it would be beneficial. I use posts and wires for a trellis. Till part of my vines with a small one-horse cultivator; the balance of them I mulch. Have tried Concord and a red and a green grape, but discarded the latter two, as they were poor bearers. I would recommend Concord for this locality, as it is the most satisfactory. Gather my grapes carefully by hand; market them in Lincoln Center, receiving five cents per pound for the first, and later on only two and one-half cents per pound. They are not profitable at present prices, excepting for home use. Have never sacked the fruit.

William BaIRD, Vesper, Lincoln county: I have about 500 grape-vines on black, sandy loam creek bottom which is nearly level; they are Concord, Elvira, Pocklington, Schuylkill, and several others. Would recommend Concord, Elvira, Schuylkill, Clinton, Pocklington, Niagara, and Moore's Early. Plant one-yearold vines. Cultivate with a five-tooth cultivator and one horse. Have not bagged grapes, as I think that for exhibition purposes only, and would not advise it. Cut from the vines with a sharp knife or shears, pack in five-or tenpound baskets, and market at home. A good vine will yield one dollar's worth of grapes. I consider them a paying crop. I have put up unfermented grape juice; cook in porcelain kettle, squeeze out the juice, skim, bottle and seal up while hot. Cider from apples can be treated in same way. The grape is undoubtedly adapted to this soil and climate, and is a good paying crop if properly cared for. I plant my grapes eight feet apart each way. Prune after the California style; that is, run them up eighteen or twenty inches high, then form a head, and cut back each year to two or three buds, owing to the strength of the vine. I keep them staked up until they are strong enough to support them- 
selves; that will be in about two or three years. I trim off surplus wood after they are done blooming and are in full leaf - they will not bleed then-leaving just enough bearing wood to hold what fruit the vines will support. I sometimes make a little frame around the base of the vine to hold the grapes up off of the ground, but this is unnecessary after the vines are three or four years old. This is the best style for this windy country; they are handy to gather, easy to cultivate, and they look well. I also irrigate, which is of great benefit to grapes here.

Mark Boulware, Blue Mound, Linn county: I put out 2000 Concord grapes in 1869 , but they are about all gone now ; they were on red, mottled soil; I think a southeastern slope preferable; set two-year-old vines, $6 \times 8$ feet; prune back to two or three buds in the fall, and nip them back during the summer to keep them in shape; tie my vines to stakes; cultivate with a small, spring-tooth harrow and a hoe, which I consider the best tools for this work; have tried Concord, Isabella, and Clinton; have discarded the latter two, because they drop so badly and are inferior to the Concord; I would recommend the Concord for this locality; gather in baskets and market at home; I used to receive three to five cents per pound; it did not pay me, and therefore would not advise extensive planting here; have never sacked the fruit.

J. W. Latimer, Pleasanton, Linn county: I have about two acres of grapevines, planted on black limestone land. Slope makes no differerce, if the land is well drained. Set one- or two-year-old vines, $8 \times 8$ feet. Prune after the leares drop and before the sap starts again; also summer prune to check too rank a growth of the strong leaders. Use one stake, four feet high, to each vine. Give them shallow culture with a plow, if not mulched; a hoe is the preferable tool for this work. I do not mulch my vines, but it is highly advantageous. Have tried Concord, Clinton, Elvira, A ugust Giant, ten or fifteen of Rogers's hybrids, Worden, Martha, Pocklington, Niagara, Moore's Early, Taylor, Champion, Delaware, Ives, Virginia Seedling, Jefferson, Brighton, Catawba, Logan, Northern Muscadine, Dracut Amber, etc. Have discarded all excepting Concord, Moore's Early, Worden, and Niagara (if you want a white variety), because they did not pay for the expense of raising. The Concord and Moore's Early do best here. Gather and market in baskets, but they are not a paying crop excepting for home use. I would not advise planting extensively here. Have never sacked the fruit to protect it. We put up unfermented grape juice in bottles, the same as we can fruit. My experience with the Worden is such that I am led to believe that I have always received the Concord; if not, then I can see no difference in vine or berry: therefore $I$ leave it out of the above list.

W. M. Fleharty, La Cygne, Linn county: Set my vines $10 \times 12$ feet; cultivate with a small diamond plow; prune in February, leaving two or three buds; make my trellises of wire; sometimes I prune a little in summer to keep the vines in shape; have never bagged grapes, but think it would be beneficial; market at home; I think them a valuable crop for family use; we have put up unfermented grape juice; we extract the juice, boil, and can it. I have grown vines in a small way for the last thirty years, and the worst enemy I have to contend with is the grape-berry moth. I find that grapes with a very thick skin succeed best. At this date (A ugust 1) the Ives is free from defective berries, while nearly all other varieties I have are badly injured. I have never been a lover of the Ives, but today every cluster is perfect, and it has always been so, but its flavor is not as fine as some others; the vine is a rapid grower; it revels in rich soil, and never in thirty years has it gone back on me; it makes sound berries and perfect clusters. Concord, Niagara and Moore's Early badly damaged by moth; Delaware not so much. 
J. E. DAvid, Winona, Logan county: I have no grape-vines now, as they are all dead; were planted on level land, but I think a southern slope preferable; set two-year-old vines, four feet apart; pruned in the spring, just as they were budding out; never summer prune; used a frame trellis; till with a cultivator and hoe, but think a double-shovel plow and a hoe the best implements for the work in this locality; I did not consider them a paying crop, and would not advise extensive growing; have never sacked the fruit.

Thomas Craig, Americus, Lyon county: Have four dozen grapes, of seven varieties, planted on second bottom; I do not think slope makes any difference. Set two-year-old vines, eight feet apart, in rows ten feet apart. Prune in December by cutting back to two or three buds; also summer prune; keep all sprouts rubbed off, and pinch back to third or fourth joint from bunch. Use a trellis of posts and wires. Till with a double-shovel plow until the 1st of August; think a horse hoe the best tool for this work; a dust mulch is very beneficial, and then mulch liberally with stable litter in the fall. Have tried Concord, Martha, Elvira, Pocklington, Missouri Reisling, Moore's Early, Worden, and Dracut Amber. Planted ten more varieties this spring; they are the latest and best. Among them are Campbell's Early, Green's Early (both new), Moore's Early, Worden, Elvira, Missouri Reisling, and Pocklington; the latter is good, but a poor grower. I would recommend Moore's Early, Worden, and Moore's Diamond. Gather my grapes with scissors or a knife into baskets, and sell at home or in Emporia, receiving three and one-half cents per pound for Moore's Early and two cents for balance of crop. They pay, because they are the surest crop we have; but I would not advise planting largely. Have never bagged my grapes, but thiuk it a good plan and we may have to resort to it; although the market is so far away and express charges so high that I doubt if it would pay at two cents per pound for grapes.

W. WALTERS, Emporia, Lyon county: I have one acre of grapes planted on second bottom of the Neosho river; my varieties are Concord, Worden, Ives, Elvira, Dracut Amber; have discarded Elvira, as it is unsalable. I would recommend Concord and Worden. I prefer two-year.old vines, set seven by ten feet; cultivate first with a stirring-plow, then with a cultivator and drag. Prune my vines to two or three buds in February. My trellis is of posts and three wires. I do not summer prune. Have never bagged my grapes. Gather in baskets and sell mostly in Emporia. I have realized $\$ 100$ per acre from them, but my vines are getting old now. I consider them a paying crop. I have put up unfermented grape juice; I press the juice out, boil, skim, and seal in quart bottles.

DAN'L C. Overly, Hartford, Lyon county: I have 100 grape-vines growing in black loam. I prefer sloping land on account of drainage. Set one-year-old vines, six by ten feet. I prune the last of February and first of March, when the frost is out of the vines, by cutting back to two buds. I use posts and four wires for a trellis. I plow the ground in the spring and cultivate after each rain; a cultivator and harrow are good for this work. Do not mulch. I never summer prune, as it is a bad thing to cut back the green shoots. Have tried Concord, Worden, Moore's Diamond, Moore's Early, Niagara, Clinton, and Hartford. Have discarded Clinton, Moore's Early, and Hartford, as they were unprofitable. I would recommend Worden, Concord, and Moore's Diamond, for this locality. Gather and market in six-pound baskets; sell them in Emporia, receiving two and three cents per pound. I do not consider them profitable, and would not advise extensive planting here. Have never sacked the fruit. Thorough culti- 
vation and spraying make fine grapes, and those who do n't give them this treatment have very few grapes which are not poor in quality. I sell from fifteen to thirty dollars' worth per year from my vines.

A. D. Chambers, Hartford, Lyon county: Have 2000 vines growing on upland sloping to bottom land; one vineyard is level, the other slopes to the south. The varieties are Concord, Early Ohio, Worden, Catawba, Clinton, Niagara, Martha, Delaware, Dracut Amber, Muscadine, etc. Have discarded all but Concord, Dracut Amber, Worden and an extra-early grape; would recommend this list. The Concord has been my only paying grape. Plant No. 1 yearling vines, seven by eight or eight by nine feet. Cultivate with a plow; generally plant early potatoes and corn between the rows. Prune in February or March to two or three buds; summer prune but not thoroughly, as I haven't time. I have used stakes as trellis, but wire is preferable. Have not bagged any, as they are too cheap to pay for the work. Gather in baskets, half bushel and less, owing to the distance they are to go; prefer small packages. Market at home; the grapes are fine and there is a ready sale for them; realize about fifty dollars per acre; counting labor and expense of growing grapes, the profit is about the same as that for corn or potatoes.

T. W. Allison, Florence, Marion county: I have about 250 grape-vines, planted on a rich, black loam having a deep subsoil, part of which is level and part on a southern slope. Varieties tested are Concord and Worden. Would recommend both. I plant yearling and two year.old vines, eight feet each way. Cultivate very shallow; keep them clean of weeds all the time. Prune in February or March, fan system; pruned in summer three years ago, but it did not pay. It only causes laterals to grow where they will be cut away in the winter pruning. I think a four-wire fence six feet high makes the best trellis. I bag grapes for late home use; it pays well for 200 bags and time; it keeps the grapes nice and plump till frost. Cut grapes with common shears; prefer eight-pound baskets. Market at Florence. I realized in 1898 at the rate of over $\$ 100$ per acre. Hail killed the crop of 1899 . I consider them a paying crop. We have put up unfermented grape juice; stew the grapes and press out the juice, heat to boiling-point, and can in glass jars, air-tight. We have plenty of water, and irrigate our vineyard whenever it needs it.

J. T. Meierdircks, Florence, Marion county: Have 1000 grape-vines, planted on calcareous loam having a northern slope. I set two-year-old vines, $6 \times 8$ feet. I prune on the Kniffin system, in February; do not prune during summer, excepting where the green shoots interfere with the cultivator. My trellis is two continuous wires. Till frequently with a two-horse cultivator followed by a weeder. Do not mulch. Have tried Concord, Worden, Niagara, Delaware, Woodruff Red, and Moyer. Have discarded none, but the Delaware is not very thrifty. The Concord and Worden do best; would recommend these, with Elvira and Green Mountain, for this locality. Market my grapes at home, realizing two and one-half cents per pound; think they pay fairly. Our market would not warrant planting extensively. I think every one ought to put out a few vines.

JAMES McNicol, Lost Springs, Marion county: Have five acres of grapes, planted on dark limestone soil which slopes slightly to the northeast. Varieties tested are: Concord, Worden, Moore's Early, Elvira, Brighton, Early Victor, Martha, Empire State, Niagara, Wyoming Red, and Catạwba. Have discarded Empire State and Early Victor. Would recommend Worden, Concord, Wyoming Red, Martha, Niagara, and Brighton. Have tested Campbell's Early, but it is not up to expectations yet. Plant one-year-old vines, $8 \times 9$ feet. 'Till with a 
one- and two-horse cultivator. Prune by cutting back to two eyes; never summer prune. Prices will not warrant bagging grapes. I prefer eight-pound baskets; market at home and at Lost Springs. I realize from twenty-five to thirty-five dollars per acre. They are a paying crop.

Stephen Stout, Axtell, Marshall county: I am raising Concord grapes for family use only, and am succeeding very well; our soil is a very fine, black loam; subsoil, porous clay that holds water well. My neighbors' bees have troubled me very much; they suck out the juice, leaving the skin and pulp; hence the cheese-cloth experience gives good results. I can keep the cloth from year to year, with care. I set my vines six feet apart; cultivate with a six-tooth cultivator; prune in March, when not frozen; in the summer I pinch off the ends of the vines, as it gives more strength to the fruit. My trellis is made of two.inch slats nailed to posts. I never bag grapes, but instead put cheese-cloth over the vines, with a stone in each corner to hold it down; this keeps bees and insects off.

C. E. DrCkey, Irving, Marshall county: I have sixty grape-vines growing on level, black loam; they are Concord, Worden, and Salem. I would recommend these varieties, but the Salem needs protection in winter. I plant two-year-old vines, eight feet apart; cultivate shallow in the spring, and mulch the 1st of July; prune in February; never summer prune; the sun scalds the fruit if pruned during warm weather; have never tried bagging. . I put up unfermented grape juice; my process is to scald and press the pulp, and then strain, and can in glass, as we do fruit.

James M. Williams, Home, Marshall county: I have 300 grape-vines growing on black loam underlaid with limestone which slopes to the southeast. My varieties are Concord, Moore's Early, Hartford Prolific, Newton, Pocklington, and Niagara; all of them excepting the Concord and Moore's Early winter-killed. These two varieties I would recommend. I prefer two-year-old vines, set six to eight feet. The first year I plant corn between the rows as a shade; the second year I plant potatoes and cultivate well; prune in the fall. My trellis is three wires stapled to posts. I do not bag my grapes, and know nothing about it. I cut the grapes from the vine with a sharp knife, and place in baskets; sell to the neighbors and in town of Home, receiving from two and one-half to five cents per pound. I consider them a paying crop. In the winter of 1898-'99 the vines were all winter-killed, so that the crop of 1899 was a failure; about May 1, 1899, we were satisfied that the vines were killed, so we cut them off. The Moore's Early and Concord sprouted up and made a vigorous growth, and are bearing full this summer [1900], but not one of the other varieties ever started. A neigh bor of mine has a vineyard of 1000 grapes, nearly all Concord; they were winterkilled; some of them he cut back, others he left. Those that he pruned sprouted and made a good growth, but those that were left never sprouted, and that is the case with all I have talked with.

Charles Fern, Lindeborg, McPherson county: I have a few grape-vines growing on clay subsoil. An eastern slope is better than a northern, but slope makes no difference if the ground is well drained. Plant either one- or two-yearold vines, eight by nine feet; prune and tie them to the trellis, which is common posts and wires, early in March. Cultivate with a one-horse Planet Jr. hoo; a five-toothed hoe, with the fifth hoe behind, is the best implement. I have mulched, but it draws the roots to the surface, and then when the winds blow the mulching off they winter-kill. Have tried Concord and Moore's Early. Have discarded the latter, as it was not satisfactory. I would recommend the 
former, as it does well here. They are a paying crop for home use, but would not advise extensive planting in this locality. Have never sacked the fruit. We put up unfermented grape juice; sweeten it, and seal tightly in jugs.

Frank Huston, McPherson, McPherson county: I have one-half acre of grape-vines growing on prairie upland. I think slope makes a difference; I would prefer an eastern, so as to receive the morning sun, and as a protection from the hot afternoon sun. Set one-year-old vines, eight feet apart. I prune during the fall on the spur system, leaving two arms; also summer prune, if the season is wet. My trellis is made of posts and three wires; I tie all vines to the lower wire; the young shoots tie themselves to the upper wires. Cultivate with a one-horse plow; a five-tooth cultivator and hoe are best for this work. I do not mulch, as it causes the roots to grow too near the surface. Have tried Concord, Worden, Delaware, Pocklington, Brighton, and Agawam. Have discarded as unprofitable all but Concord and Worden. The Concord, Worden and Salem do best here; I would recommend the former two for commercial purposes, and add Delaware, Pocklington, Salem and Agawam for family use. I receive three cents per pound for my grapes; but they do not pay, in this locality, on account of birds, and I would not advise extensive planting. Have never sacked the fruit, but shall either do this or use a shot-gun this season. We have put up unfermented grape juice; boil and can it, the same as fruit.

Mrs. G. O. VICK, Fowler, Meade county: We have 250 grape-vines growing on sandy loam; they are Concord, Agawam, Delaware, Goethe, and Moore. I would recommend all this list excepting the Agawam. Prefer one-year-old vines, set eight to ten feet apart. Do not cultivate much. Prune from December until February. We use wire for a trellis. We summer prune a little, because we think it best to cut off the surplus growth. Never bag them. Gather them in baskets and market at home. They would pay well if cared for properly.

B. F. Cox, Meade, Meade county : I have about 200 grape-vines growing on black loam having a clay subsoil. Set two-year-old vines, twelve feet apart. Use a six-foot trellis having four wires. Do not mulch. Prune during January, and in the summer I leave only two bunches and a bunch of two leares above the fruit. Have tried Concord and Elvira. I would recommend the Concord for this locality, as it is the most satisfactory. Use the fruit at home, and think it pays, but would not advise planting extensively. Have never sacked the fruit.

R. H. Cadwallader, Louisburg, Miami county: I would set one-year-old vines, eight by eight feet, on a northern slope, as $I$ think this best. Prune in February, and pinch back during the summer; my trellis is post and wire. Till with a Planet Jr. cultivator. Do not mulch. Have tried Concord, Elvira, and Moore's Early; the former and latter do best with me, and I would recommend the same for this locality. Gather and market in baskets. They would pay if handled properly. Would not advise planting extensively here. Have bagged my grapes, but it does not pay.

D. M. Martin, Osawatomie, Miami county: I have about 100 grape-vines planted on white-clay or ash land which slopes slightly; a western slope is preferable. I prefer one-year-old vines, if well rooted, set ten feet apart. Prune in February, quite severely; also pinch off the ends of the longest growth during summer. I desire good, stout posts, standing six feet above the ground, set half way between the vines, with two wires. Have tried only Concord; they do best all around here. Have never marketed any; use all at home. Any fruit pays that gives the family satisfaction. I would not advise extensive planting. 
P. B. Stout, Paola, Miami county: I have one-half acre of grape-vines, planted on sandstone land; a southern slope is preferable. Set two-year-old vines, eight feet apart. Prune on the arm system, in February. For a trellis I use a stake four feet out of the ground, and a single wire on top. I mulch the vines. Have tried Concord, Clinton, Catawba, Dracut Amber, Pocklington, Niagara, and several others; have discarded all but Concord, which I would recommend for this locality. Gather in baskets and sell in the home market, receiving from three to four cents per pound. They are profitable, but I would not advise extensive planting. I sack the fruit and find it pays, as the bunches grow larger and sweeter, and we receive one cent more per pound.

W. R. Stockard, Beloit, Mitchell county: Have 200 grape-vines, planted on a northeast and southwest slope. Have tested Ives, Concord, Niagara, and others, and have discarded all but Concord and Niagara, which I recommend; have tested Clinton, Delaware, Dracut Amber, Hartford, Worden, and Wilder, experimentally, but the vines were not hardy, and winter.killed. I set vines that are from one to two years old, eight by twelve feet. I till with a cultivator and then top-dress with barn-yard litter. Prune in February; do not summer prune, but keep the leaves to shade the grapes. My trellis is posts and wire. Have not bagged grapes; have never tried it. Market them at home; think they are healthful; I consider them a paying crop. I am a prohibitionist and do not put up unfermented grape juice; I live in Kansas.

J. T. BARnes, Beloit, Mitchell county: Had one and one-third acres of grapes, but lost one-fourth of an acre with mildew. They are planted on a low, sandyloam bottom having an east aspect. My varieties are: Arminta, Concord, Niagara, Wilder, Herbert, Early Victor, Woodruff Red, Wyoming, Moore's Early, Worden, Delaware, Elvira, Green Mountain, and Perkins. Have discarded Catawba, Pocklington, Arminta, and Green Mountain. Would recommend Concord, Niagara, Wilder, Herbert, Early Victor, Worden, and Delaware. Have experimentally tried Catawba, Pocklington, Eaton, Early Ohio, Lady Washington, Lutie, Martha, Moore's Diamond, and Telegraph, but had very poor success with these. They winter-killed in two or three years. I plant No. 1 yearling vines, twelve feet a part, in rows nine feet apart-wide give better results. Cultivate with Planet Jr. horse hoe; use sweeps; stir the ground two to three' inches deep, and cultivate ten to twelve times every season. Prune in February. Do not summer prune, as I think it is too much work, and does not pay. My trellis is made of four wires and posts. I have bagged grapes, and would advise it if done before the hot weather sets in, as it keeps the grapes cool, and protects from birds and insects. Cut the bunches with shears and pack in eight-pound baskets. Market at home. When the crop is full I realize about $\$ 100$ per acre. I consider them a paying crop. Have put up unfermented grape juice. When canning grapes we pour off the surplus juice, and seal in bottles while hot. I find that, on the lowest ground I have, the Concord are very susceptible to mildew; the Victor but little. The Niagara, Herbert and Wilder resist mildew well. The Arminta and Perkins suffer frcm mildew when planted on low ground. This season Concord, Niagara, Early Victor, Perkins, Elvira, Delaware and Moore's Early are loaded with fine, large clusters, and with good rains from now. on the crop promises to be a large one. The vines range in growth from fifteen, to thirty feet. I trim on the renewal system, as I get better results than from. the spur system, and find that my rows that are set ten feet apart, with vines, ten to twelve feet in the rows, produce the heariest crops. The Niagara and Early Victor are superb bearers. 
Samuel L. Detwiler, Glen Elder, Mitchell county: Have one dozen grapevines, planted on sandy loam. Set two-year-old vines, $6 \times 8$ feet. Prune, in November, by cutting back to two buds; also pinch the green shoots back during summer. I have.a wire trellis. I keep the weeds down with a cultivator and hoe. Mulching is detrimental. Concord does best with us. Have nerer had enough to market. Would not advise planting largely. Have never sacked the fruit.

NoAH E. Bouton, Cherryvale, Montgomery county: I have 100 grape-vines, planted some on mulatto and some on light soil. I prefer an eastern slope, as I think slope makes considerable difference. Set two-year-old vines, eight feet apart. Prune close, in February. My trellis is posts and wires. Till them with a double-shovel plow or cultivator; I think the double-shovel plow best. I mulch my vines; the more the better, so you do n't get too close. Have tried Concord and Isabella; have discarded the latter on account of shy bearing; would recommend the Concord, as it does best with us. Pick my grapes, and market in Cherryvale and with neighbors, receiving from three to five cents per pound. I consider them a paying crop, and would advise planting extensively. Have never sacked the fruit. I think the Concord grape could be raised with profit, because they bear nearly every year in this locality; rot is the only drawback; but I think that is caused largely by neglect in pruning - allowing too much shade for the fruit.

P. C. Bowen, Cherryvale, Montgomery county: I have one-half acre of grapes in bearing, planted on dark, sandy loam. I prefer a northern slope. Set twoyear-old vines, generally $8 \times 10$ feet, but the variety has much to do with the distance apart. Prune in the fall; cut back to one or two buds on each cane. Also prune during summer, to give plenty of sun and light. Use a wire trellis nailed to posts. Cultivate four to six inches deep, with a Planet Jr. horse hoe and a hand hoe, which I consider the best tools for this work. Do not mulch my vines, excepting with soil. Have tried Concord, Moore's Early, Dracut Amber, Delaware, Agawam, Telegraph, Norton's Virginia, and several others; have discarded all but the three first named. They were not hardy, were unprolific, and unprofitable for either home or market. The varieties that do best here are Concord, Dracut Amber, and Moore's Early; I would recommend these three, in the order named. Gather the fruit in eight-pound baskets, and market in Cherryvale and other Western towns; they pay better than apples or peaches. But I would not advise extensive planting. Have never sacked the fruit; I spray early with Bordeaux mixture, to prevent rot, and find it pays. We put up a little unfermented grape juice; boil down one-third, and bottle; keep in a cool place.

$J_{A C O B}$ Good, Coffeyville, Montgomery county: I have three acres of grapevines, planted on limestone land. Set one-year-old vines, six to eight feet apart. Prune, early in February, to two buds. I find a trellis the best means of keeping the vines up. Till them with a five-toothed plow and harrow. Do not mulch. Have tried Concord, Moore's Early, Niagara, Pocklington, Martha, Elvira, Ives, Moore's Diamond, and Clinton. Have discarded Clinton, Martha, Elvira, and Ives, as they seem unadapted to this climate, and are unprofitable. Those that do best here, and which I would recommend, are Moore's Early, Concord, Pocklington, Niagara, and Moore's Diamond. Gather in baskets and sell in local market, receiving four cents per pound for Moore's Early, and two cents per pound for Concord and Niagara. They pay fairly well, but I would not advise 
extensive planting here. Have never sacked the fruit. I have put up unfermented grape juice; first press out the juice, then heat and seal, in pint and quart bottles.

J. C. Ross, Havana, Montgomery county: I have 400 grape-vines growing on sandy loam. They are Concords. I prefer two-year-old vines, set eight feet apart. Cultivate with the hoe, and then mulch. Prune in February. My trellis is made of smooth wire. I summer prune my vines by pinching, as I think the yield greater. Have never bagged my grapes, and would not advise it. Gather in small baskets, and market in our home town. I realize from 50 to 200 baskets per acre. They are a paying crop. Have put up unfermented grape juice; I use the cider-mill to press the juice out. This is a good grape county.

F. L. Kenoyer, Independence, Montgomery county : I have 500 vines on rich, sandy loam, with a southern slope. My varieties are Moore's Early, Concord, Martha, Worden, Dracut Amber, Niagara, and Clinton. The Clinton rots badly and is a poor market grape; Moore's Early is most profitable; Worden usually ripens too unevenly; otherwise it is better than Concord; Niagara and Martha are profitable for home market. I prefer one- and two-year old vines, set in rows nine feet apart; plants eight feet apart in the row. Cultivate by breaking shallow each spring with a stubble plow, and cultivate through the summer with Plan et Jr. twelve-tooth cultivator. This keeps the roots below the surface. Prune during the winter, removing all weak canes, and cutting laterals back to four or five buds. My trellis is of posts and two wires. I do not summer prune, as it interferes with the formation of canes for the next year's crop. Every bud or leaf removed from a vine in summer produces a shock which interferes with the proper development of its fruit. I have never bagged my grapes, but am satisfied it would pay well in protecting them from fungous diseases and lengthening the ripening period. I gather my grapes by cutting the bunches with pruning shears and remove all defective berries, and market at home in fivepound baskets. I realize about twenty. five cents per vine, and consider them a good, paying crop.

W. H. Robinson, Dunlap, Morris county: I have 100 grape-vines, planted on rich bottom land; they are Concord, Worden, Moore's Diamond, and Martha; will discard Martha, because of tenderness; would recommend Worden and Concord. Prefer two-year-old vines, set eight feet apart; cultivate with a five-tooth cultivator; prune during early winter; do not summer prune, but believe it would pay. My trellis is made of poles. Do not bag the fruit. Cut from the vines with a knife; market at home. I consider them profitable.

John E. SAmple, Beman, Morris county: I have 2500 grape-vines growing on black loam sloping to the southeast. They were bought for Concord, but are a far better black grape; I call them "Care's Fraud." I would recommend this grape, as I have had them fifteen years, and they have never missed a crop; thirty pounds of them make five quarts of juice. I prefer two-year-old vines, set twelve feet apart; mine are eight feet; till shallow, with a cultivator; prune in February and March, leaving three buds; I never summer prune, but think it would pay and make larger grapes. My trellis is wire. Never bag my grapes, and think it would pay only for market. Cut with shears, and pack in twentyfive-pound crates; sell at Council Grove and in the country, realizing three cents per pound for them; I consider them a paying crop.

JAMES SharP, Parkerville, Morris county: Have three acres of vineyard growing on black surface soil with a porous red-clay subsoil, sloping to the east. 
Varieties are Moore's Early, Concord, Worden, Ives, Telegraph, Pocklington, Niagara, Martha, Elvira, and Rogers's hybrids; have discarded Rogers's hybrids, as they are not hardy. Would recommend Worden, Concord, Niagara, Pocklington, and Moore's Early. Have experimentally tried Janesville, with which I had no success. Set vines seven feet, in rows eight feet apart. Cultivate with plow and hoe. Prune in spring; have not found it profitable to summer prune. My trellis is made of posts and two smooth wires and one barbed wire. Have not bagged the fruit; think it not necessary. Use a knife and shears to clip the bunches from the vines; pack in baskets and market in nearby towns, receiving from two to four cents per pound; they are a paying crop.

John A. Gonpon, Viroqua, Morton county : I tried a dozen Concord grape-vines on sandy soil, eight or ten years ago, but drought and grasshoppers killed them in five or six years; we had a few bunches of fruit the third year. I think a row of Russian mulberries which overshadowed them helped kill them, as they kept the ground too moist. [??] I am going to try them again as soon as we have storage reservoirs from our wells, which are 150 feet deep.

L. G. Morgan, Richfield, Morton county: I have very few vines; they are planted on level sandy loam. Set them ten feet apart; cultivate with a hoe. Do not prune. My trellis is of $1 \times 4$-inch boards. Do not bag them, and would not advise it, as I do not think it necessary. Cut the grapes from the vine with a knife. I consider them a good, paying crop. They are hard to get started here, but after they do start they grow well, and bear good crops. I do not know the name of the variety I am growing, but it does well and has abundant crops. I irrigate my grapes with the suds from the washing-machine.

A. Oberndorf, Jr., Centralia, Nemaha county: Have eleven acres of grapes, planted on an eastern slope. They are Concord, Worden, Moore's Early, Early Victor, Ives, Telegraph, Dracut Amber, Cottage; have discarded all these excepting Concord; some winter-kill; others do n't do well. Would recommend Concord. If I was planting another vineyard in Kansas, I should plant only Rogers's hybrids, and cover them every winter. These do well here, and bring double the price of the Concords. I have a few Agawam which I planted twenty years ago; they have never failed, always produce well, and seem as hardy as when they first came into bearing. These I would bag. Have tried about thirty $v$ arieties experimentally, but had poor success with them unless they were covered in winter. I planted one-year-old vines when setting the vineyard, but used two-year-old when resetting and when planting experimentally. Set them eight feet apart. Cultivate with a disk harrow. Prune on fan system, after the leaves have fallen; do not summer prune, as I cannot see any benefit in it. I think a three-wire trellis is best. Bag only for home use, as it is too much trouble. Gather in ten-or twenty-pound baskets, but prefer eight-pound baskets. Market at home, Kansas City, and west of here. I consider them a fairly paying crop. Have put up unfermented grape juice for home use. Heat the juice to 170 degrees, then bottle, and surround the cork with paraffin wax; and when we get ready to use it half of it is usually gone.

O. K. Wilcoe, Corning, Nemaha county: I have fifty grape-vines growing on a southern slope; they are Concord. Would recommend Concord, as it is productive and hardy. I prefer vigorous one-year-old vines, set twelve feet each way; cultivate first year, then mulch; prune back to one or two stalks in spring, to force the fruit. Never bag them; it does not pay for home use. They are a paying crop if cared for. 
H. C. Riggs, Wetmore, Nemaha county: I have about ope acre of grape-vines, planted on sandy, gravelly soil having a western slope; the varieties are Moore's Early and Concord. Concord is best. I prefer one-vear-old vines, set $6 \times 10$ feet. Cultivate with a one-horse, five-toothed cultivator and a double-shovel plow. Prune thoroughly, in February, before the sap starts; do some summer pruning, to avoid excess of vine. My trellis is two or three wires and posts. Never bagged grapes. Cut from the vines with shears. I have not sold any, as this is my first good crop. I consider them a good-paying crop. My grapes have done well this year. I cultivate in the spring, as soon as the ground will work good, with a double-shovel plow, being careful when next to the row not to go too deep; then once a week afterwards, with a five-toothed cultivator, until August, or later if weeds grow badly, using a hoe to clean out all weeds and grass in the rows. I prune all excessive laterals and unfruitful vines, being careful to have a good shade over the fruit. My early grapes show signs of blighting, as they did last year. I went in with the shears last week [July 23], and pruned very severely, cutting many vines within six inches of the clusters; they seem to be recovering vigor, and promise to ripen up well.

W. W. Gardiner, Chanute, Neosho county: I have twenty-four grape-vines - the Concord and one other variety. I prefer two-year-old vines, set seven feet each way. Cultivate with a hand cultivator, but would use a horse if I had many vines. My trellis is made of hedge posts, with poles nailed on for the vines to cling to. I never summer prune, because I want long vines, and cannot see well when the leaves are on. I think them a good, paying crop, and that more money can be made from them than from any other fruit we raise in Kansas, if a market can be found for them.

O. M. RECond, Thayer, Neosho county: My grape-vines are planted on sandy loam having a southeast slope. My varieties are Concord, Moore's Early, Brighton, Telegraph, Ives, Dracut Amber, and several other varieties that I do not remember the names of. Discarded Telegraph because it rots badly; Brighton, because of shy bearing; would recommend Concord, Moore's Early, Ives, Dracut Amber, and Niagara. Others not yet in bearing are Worden, Goethe, and Cynthiana. Plant one- or two-year-old vines, eight feet apart. Cultivate with one- and two-horse cultivator and hoe. Prune from December to February; also in summer, because it makes finer bunches. My trellis has two wires, one three and the other five feet from the ground; have some tied to single stakes. I bag my grapes, partly to preserve nice specimens for our county fair, and have taken the premiums five years out of six. I sometimes use a paper meal sack and enclose a whole branch that has several bunches, but would not advise it on a large scale; bagged grapes will often keep perfectly on the vines until November.

G. Schмокеr, Urbana, Neosho county: I have 150 grape-vines, planted on poor land, underlaid with hard-pan. Plant one-year-old vines, eight feet each way. Prune the last week in February and first two weeks in March; also prune two or three times during summer. My trellis is made of posts, sixteen feet apart, and three wires. Cultivate with a double-shovel plow, five or six times a season; this implement, or any one-horse cultivator, is good if the ground is not weedy and is in good shape. I do not mulch; do not think it would be beneficial more than one or two years. I have tried only Concord, and think it best for this locality. Have marketed none; use all at home. I would not advise extensive planting. Have not sacked the fruit, as it has not been troubled much with anything so far. Grapes do well here; all they need is constant 
shallow cultivation, so they will not suffer during the dry spell which we always have at ripening time. I would not advise planting for commercial purposes, but would plant 100 to 150 vines for home use; they will do well on most any soil, just so you keep it stirred and free from weeds.

F. A. Barber, Ransom, Ness county: I have fifty grape-vines, planted on sandy loam not far from water. A northeast slope is preferable; plant two-yearold vines, eight feet apart; I mulch my vines; am trying Concord; would not advise extensive planting; have never sacked my grapes, as I am a new beginner and have had no experience.

W. H. Akers, Cactus, Norton county: I have 225 grape-vines growing on bottom land, which I prefer; set one-year-old vines, six feet apart; prune by cutting out the old wood, in November; pinch back once or twice during summer. I use stakes five or six feet high for trellis; cultivate with double-shovel plow and hoe; do not mulch my vines; have tried Concord, Worden, Diamond, and Ives; have discarded the latter, as it wilts on the vines as soon as it begins to ripen. I would recommend Concord, Worden, and Diamond, as they do best in this locality; cut the grapes with a knife, and sell at home for four cents per pound; they scarcely pay. I would not advise planting them extensively; have never bagged my grapes.

J. J. Alexander, Norton, Norton county : My grapes are planted on a southeastern slope. Have tested Concord, Worden, Niagara, Elvira, and Champion. Have discarded all but Concord, Worden, and Niagara. Plant No. 1 one-year-old vines, six feet apart. Mulch to keep the weeds down. Prune the young growth severely in February. Do not summer prune. I think posts and smooth wires make the best trellis. Do not bag my grapes, as the wind and rain destroy paper bags. Market the fruit at home. They are a paying crop here.

J. Q. Lloyd, Barclay, Osage county: I have 150 grapes, planted on creek bottom, set at two years of age, ten feet apart, in rows eight feet apart. I prune on a fine day in February; also cut off all unnecessary shoots during summer. My trellis is hedge posts and galvanized wire. Cultivate with a disk harrow. Do not mulch. Have tried several varieties of grapes, but discarded all but Concord, as they did not pay. Would recommend only the Concord for this locality. Use all the fruit at home, and consider them a paying crop; but would not advise extensive planting. Have never bagged the fruit.

Olof Larsen, Lyndon, Osage county: I have about 100 grape-vines growing on light loam: I think a northern slope preferable; set my vines $10 \times 12$ feet; prune in March, by cutting off about all new growth. My trellis has three strands of No. 9 wire. Till with a cultivator; a plow and one-horse cultivator are the best tools; do not mulch. Have tried the Concord only. Most assuredly they are a paying crop for home use. Have never sacked the fruit to protect it.

Godfkey Fine, Maxson, Osage county: Have fifty bearing vines, mostly Concord, on bottom land. I plant one- to two-year-old vines, seven feet apart; cultivate with a hoe; prune in February; do not prune during summer. My trellis, which is as good as any, is made of posts and wires. Market at home.

W. G. ShorT, Twin Creek, Osborne county: About all varieties do well here for such culture as they get. They are generally planted in unfavorable places in the orchard, and with no particular care. Worden and Concord are favorites. 
J. L. Steel, Minneapolis, Ottawa county: I have 100, vines, planted on a southern slope; they are Concord, Worden, Niagara, Elvira, Pocklington, and Moore's Early. All varieties do well here, when buds are not destroyed by the spring frosts. Plant two-year-old vines, $8 \times 10$ feet; cultivate with an eight-tooth cultivator; prune severely in December. My trellis is made of posts and No. 9 wire. Always summer prune at the base of the vine, to keep the multitudinous suckers from sapping its vitality. Have never bagged the fruit, but think it a good plan, and would advise it, as an experiment at least, to obtain perfect specimens. Gather with pruning shears; market at home. The birds! the beautiful birds! are the great drawback to grape culture here. As soon as the grapes begin to ripen, the birds take their share, and some more, and what they leave are not marketable; so that the only return derived from the grape crop is for the table. I have mulched to some extent, but it causes the roots to grow too near the surface; surface irrigation tends to the same evil. I think that subirrigation by means of tiling or pipe would work to good advantage for the grape.

Geo. Geissler, Tescott, Ottawa county: I think grapes do best on a southeast slope, where they get most of the sun. Our sterile uplands, even gravelly slopes, are preferable to heavy bottom land. Set one-year-old vines, $8 \times 8$ feet, if you have plenty of room. Prune on the renewal system, in the fall, after the leaves fall, and before the buds swell in the spring; pruning to induce the vine to bear is the one great difficulty not easily explained without practical experiments. When the vine has spun out in long, endless tendrills all over the trellis and neighboring vines, it is a difficult job to bring it back to a proper shape. We must keep pinching the ends of the shoots off all summer; thus producing the young shoots, destined to bear the next season, nearer to the center of the plant. In the fall or early spring they should be shortened in to about five feet in length, leaving three or four buds to the cane and four to six canes to the plant; the following year we should try to discard as much of the old wood as we leave young; thus continually renewing the plant, and keeping only young, one-year-old canes for bearing. For a trellis, I use anything that is convenient. Since the average farmer has neither much time nor experience to bestow, it is best to have only a few vines, and those robust and hardy. It matters little how they are supported; low, bushy vines trailing on the ground bear good fruit, as hot winds cannot damage them so much in that shape as when on high trellises. Plow in the spring, and then keep clean. A five-toothed cultivator is the best tool for this work. I mulch with wood chips or manure, and work it in the following year. Have tried Concord, Martha, Virginia Seedling, Delaware, Iona, Catawba, Louisiana, Goethe, Rogers's seedlings, Elvira, Moore's Early, Worden, etc.; have discarded everything but Concord, Elvira, and Moore's Early; some were weakly and others unproductive. I would recommend these three varieties for this locality.

William A. Gill, Larned, Pawnee county: I have a few grape-vines, planted on dark loam. Set two-year-old vines, six feet apart. Prune in the spring. Use a trellis of posts and wire. Cultivate with a one-horse plow. Do not mulch. Have tried Hartford Prolific and Concord; the latter does best here. I would recommend only dark grapes for this locality. I consider them a good, paying crop, and would advise extensive planting. Have never sacked the fruit, but believe it would pay, as a protection from the birds.

S. S. Dickinson, Larned, Pawnee county: I bare 500 grape-vines growing on sandy river bottom, having a northeast aspect. My varieties are Concord, Niagara, Iona, Martha, and Delaware. I plant two-year-old vines; set them 
$6 \times 10$ and $8 \times 10$ feet. Cultivate with a plow, a cultivator, and a scythe. Prun $\theta$ in March and April. My trellis is of wires and posts. I mow the ends of the vines during summer; they make too much vine, to the detriment of the fruit. Sack my grapes, but do not advise it, as the wind and rain use the sacks up. Market at home.

F. T. M. Dutcher, Phillipsburg, Phillips county: My grape-vines are planted on sandy loam. Varieties tested are Pocklington, Moore's Early, and Concord; have discarded all of them but Concord. I plant yearling vines, eight feet apart, and cultivate as for other crops. Prune in February; pinch during summer. I think galvanized wire makes the best trellis. Market my crop at home. I do not consider them a paying crop.

D. F. Young, Long Island, Phillips county: I did have twenty-four grapevines, but they were all winter-killed the past winter; they were planted on deep, black upland soil. I believe a northern slope, having a clay soil, is best. Set them five feet apart. I usually prune the vines in the fall and lay them down; do not prune during summer. My trellis was posts with wires stretched on them. Cultivated them with a horse and hoe. Have tried Concord; they pay, but would not advise planting extensively. I believe grapes would do well here with proper treatment. The past few years I have been experimenting with them. I used to think it necessary to bury them in the fall, in order that they might not winter-kill. The winter of 1899 and 1900 I laid them down and covered some of them with common corn-crib fencing; on this I put small rails and brush. One healthy vine not covered came out in the spring of 1900 in fine condition - the same as those that were covered. Last winter I was very busy, and so left my grapes unprotected, like the vine mentioned above; consequently they are all dead. I believe there was not enough moisture in the ground last winter. I have always noticed that when they go into winter with the soil well soaked they come out all right in the spring. The hot sun and hot winds are very injurious to grapes; they get sunburned. I believe they should be planted in rows north and south and very close together, so that one vine would help protect another from sun and wind.

IsaAc H. Furman, Onaga, Pottawatomie county: I have about 200 grapevines, planted on a red-clay loam. I prefer a western slope, as it is not so liable to frost. Set one- and two-year-old vines, six by eight feet. Prune in the fall to make a compact head, also pinch back once during summer to cause thicker growth. I use a four-wire trellis. Till with a five-tooth cultivator. Never mulch. Have tried Concord, Worden, Elvira, Salem, Brighton, Delaware, Moore's Diamond, Agawam, and Early Ohio. Have discarded Martha, Niagara, Beauty, Empire State, Columbian, and Colrain. Concord does best here; the others are fairly successful. Market in baskets, in Onaga, receiving five cents per pound. They are a profitable crop, but I would not advise extensive planting. Have never sacked the fruit.

M. D. Weltner, Westmoreland, Pottawatomie county: I have fifty grapevines growing on sloping land; a northeast or east slope is preferable. Plant one-year-old vines, eight to nine feet apart. Prune in February and March, by cutting back to two buds on each lateral. I also prune during the summer by breaking off the superfluous sprouts. Have tried only Concord, which is the best variety for this locality. They are a profitable fruit, and I would advise extensive planting. Have never sacked the fruit.

J. J. A BLARD, Lawndale, Pratt county: I have about 120 grape-vines growing on level, black loam. They are Concord, Dracut Amber, Lindley, Moyer, and 
Diamond. Experimentally I am trying Carman, Niagara, Goethe, and Moore's Early ; Carman is quite successful. Have discarded Moyer, as not prolific; would recommend Dracut Amber, Concord, Carman, and Diamond. Prefer one-yearold vines, set six feet apart, in eight-foot rows. Cultivate by plowing shallow, and keep the five-tooth cultivator going. Prune in February, to two or four buds. My trellis is made of posts and No. 9 smooth wire. Never summer prune, because the leaves are needed to shade the fruit. Have never bagged any. Gather in one-half bushel baskets; market at home. Think them a paying crop for home use.

J. T. Everhart, Pratt, Pratt county: I have about 100 grape-vines; they are Concord, Martha, and Niagara; think the slope makes no difference. Would recommend the above list, as they do first-class here where they get moisture enough. I plant two-year-old vines, eight feet apart; cultivate shallow and irrigate. Prune any time from first of January to last of February. Think wooden trellis best. Have not tried bagging grapes, but think it would be good to keep birds and insects off. Market all I raise at home; they are profitable.

S. S. Hinerman, Chardon, Rawlins county: There are but few grapes growing in this county, although I know of some that are making a splendid growth. With proper care, I think we can grow grapes for family use, but as to whether we can grow them in sufficient quantities for commercial purposes the future will show. I regret my inability to give you any practical knowledge, on the subject.

James L. Williams, McDonald, Rawlins county: I have not been very successful with grapes on account of grasshoppers; but I believe they will be all right just as soon as the 'hoppers are gone. There are several small vineyards in this county that are doing nicely, and are full of grapes.

James BaInum, Arlington, Reno county: I have 150 grape-vines growing on valley land. Have tested and discarded Elvira, because it does not bear well; would recommend Concord, as it does best with me. Plant two-year-old-vines, $6 \times 12$ feet; cultivate with a disk; prune in February; do not prune during summer, for lack of time. I think stakes of Osage orange make the best trellis. Do not believe bagging would pay. Pick my grapes with shears. They are a paying crop. I may plant more grapes next spring. [Good!]

E. Morgan, Hutchinson, Reno county: I have 3000 grape-vines which are a success; they are planted on Arkansas river bottom land, on lightest sand and heaviest loam. I have discarded Goethe, because it winter-killed. Would recommend Concord and Moore's Early. I planted one- to two-year-old vines, $6 \times 8$ and $7 \times 7$ feet; cultivate by throwing the dirt from the vines with a plow, then hoe and, when the weeds come up again, plow the dirt back. I prune after January 1, leaving five arms to a vine; in trellising I use two wires; I prune twice during summer, to induce better growth of fruit. Have never bagged any. Cut the bunches and place in half-bushel baskets. Market in Hutchinson. I consider them a good, paying crop at the prices which we have received the last three years. They are very largely grown in this locality, and the only thing which prevents complete success is the ravages of the birds; I have known whole crops taken by the birds, and every year the damage is great. The chief destroyer is a species of oriole that migrates in August, and the man that can stop the ravages of these pests will benefit the grape growers more than I could tell. [ Bag the grapes.] I think that native birds do more good than harm, but those that 
come from the north take our entire grape crop and do no good; some means should be devised for protection; at present all we have is the shot-gun, and that is expensive and inadequate.

JAMES Dunlap, Hutchinson, Reno county: I have twenty acres, or 11,000 grape-vines, growing on level, sandy land. Of all slopes, southern is preferable. Set two-year-old vines, nine by nine feet. I prune close, from November until March 1; also prune three times during the summer. For a trellis I use firstclass posts, sixteen feet apart, and two No. 10 wires. I till them by plowing the ground early in the spring; then cultivate afterwards with a turning-plow and five-tooth cultivator. Do not mulch. I have tried a great many varieties, but discarded nearly all of them because some were unproductive, some poor quality, and others not hardy. Those which do best here are Moore's Early, Concord, and Niagara. I would recommend Moore's Early, Concord, Niagara, Ives, Catawba, Moore's Diamond, and Goethe; the latter I would plant in limited numbers. Gather and market in eight-pound baskets, which I sell at wholesale and also ship, receiving from twenty-five cents down to ten cents per basket for them. They are a paying crop if a man has a small farm and plenty of help, but if he has much other work to do, they do not pay, and I would not advise extensive planting. I have sacked the fruit to protect it. We put up unfermented grape juice for family use, in Mason's two-quart jars.

E. B. Hansen, Olcott, Reno county : I have 200 grape-vines growing on sandy soil having a clay subsoil; planted strong one-year-old vines, $6 \times 12$ feet; prune in February, also a little in summer; use a wire trellis; do not mulch; have tried Concord, Niagara, and Delaware; the Concord and Delaware do best here; I receive two and one-half cents per pound, and consider them a paying crop.

F. A. Smith, Belleville, Republic county: Have twenty-five grape-vines at present; they do well on any good corn land; slope makes little difference; northeast slope sometimes retards too early start in spring; have tried several kinds, and discarded all but Concord, as all were too tender; tried Pocklington, but drought killed it; I prefer two-year-old vines, set ten feet apart, rows eight feet, but perhaps twelve feet would be better; till with a corn cultivator, or anything that will keep them clean and the soil mellow; I prune while the vines are growing, so as to get the growth where I want it; Osage-orange posts and galvanized wire are best for trellis; have never bagged any; use all the fruit at home; they are one of the surest and best-paying crops we grow.

William H. Werner, Alden, Rice county: I have perhaps 100 grape-vines; sandy soil is preferable; would think hilly country best. Plant two-year'old vines, eight to ten feet. Prune during the fall or in February; also prune some in summer. My trellis is a stake with a cross-bar. I cultivate my grapes shallow, so as not to disturb the roots; think a shallow-working tool is best, as the roots lay very near the surface. I think mulching all right where a man can't irrigate. Have tried Concord, White Lady, Rogers's No. 4, and Clinton; have discarded the White Lady and Rogers's No. 4, because they would not stand the drought. I would recommend Concord for this locality; the Clinton also does well here, but the berries are small and not marketable. I cut the bunches with scissors or sharp knife, and sell for two or three cents per pound. Do not consider them a paying market crop, but they pay well for family use. I would not advise planting extensively here, as we are too far from market. Have never tried sacking my grapes. The birds cause considerable loss where the vines are 
tied up, but if left near the ground the birds seldom hunt out the fruit. I shot about 100 birds last year, and was afterwards told that if I would place water near the vines they would not trouble the fruit.

Dr. G. Bohrer, Chase, Rice county: I have about twenty-five grape-vines, planted on black, sandy loam having a slightly eastern slope. My varieties are Delaware, Niagara, and Concord. I prefer Concord, as it seems hardy and bears well. I plant one-year-old vines, six feet each way; cultivate shallow. Prune in February; also in summer, as this throws more substance to the grapes and prevents their dropping. My trellis is made of posts, sixteen feet apart, and wire. Have not bagged grapes, and would not advise it, unless to fertilize and produce a new variety; see no good in it excepting for this purpose. Cut the bunches of grapes close to the vine. I have none to sell, but prefer baskets. I consider them a paying crop, especially for family use. When the season is dry I irrigate. We invariably have grapes on the Arkansas river bottom lands here in Rice county. The grape roots get moisture from the river; that is found at a depth of from five to fourteen feet on most of the farm lands of the Arkansas river valley proper. On these lands irrigation is little needed. Am of the opinion that hardy varieties can be successfully grown here. Niagara is not as hardy as Concord, and will not stand drought nor cold as well. Delaware seems hardy, but requires more moisture than Niagara or Concord in order to bear and derelop well. I have one vine under the eaves of the house which gets much more water than those in the open ground; it bears quite well, while the others become feeble in dry weather and bear no fruit. No one would make a mistake by planting Concord grapes largely in this county.

H. C. Hodgson, Little River, Rice county: I have about one acre of grapevines, planted on bottom and second bottom land. I think a northern slope preferable. Have always planted one-year-old vines, five to six feet apart in the row, and the rows one rod apart. Prune the last year's growth back to one or two buds; never summer prune. My trellis is three wires, on posts twenty feet apart. Till them with a one-horse cultivator until they begin to bear; then mulch. Have tried Concord, Niagara, Wyoming Red, Agawam, Pocklington, and Campbell's Early. Have discarded the Agawam; it winter-kills. The varieties that I think best for this locality, and that I would recommend, are Concord, Niagara, and Camplell's Early; the latter has been planted only one yearnot long enough to test. Sell my grapes at home, realizing two and one-half to three cents per pound for them. They are a fairly paying crop, but I would not advise planting extensively. Have never tried sacking any.

James Anderson, Leonardville, Riley county: I have two dozen grape-vines, planted on level land. They are Concord; would recommend this variety. Set my vines six feet apart. Cultivate with a hoe. Prune in March. My trellis is made of posts and wire. Do not summer prune. Gather my grapes by hand. Market at home. I consider them a good paying crop. Have put up unfermented grape juice.

N. Christiansen, Mariadahl, Riley county: I have seventy-five grape-vines growing on second-bottom land; set two-year-old vines, $7 \times 9$ feet; in pruning, I cut off all the dead wood and part of the bearing vine; for a trellis I use posts and wire; till with a hoe, cultivator, and disk; I do not, as a general thing, mulch my vines, but think it should be done late in spring, for if it is done during the winter it will draw frost in spring and kill the bloom, and perhaps vine also; I had some killed this year; I prune a little during summer to thin out sprouts; 
I have tried Concord and two other varieties; Concord does best here; I seldom have grapes to sell, but when I do I receive from three to five cents per pound; they would be a paying crop if conducted as a business; have never sacked the fruit; we boil, skim and can grape juice, which is very useful in cooking.

G. E. Spohr, Manhattan, Riley county: I have 1800 grapes, planted on a sandy loam which slopes slightly southeast. My varieties are Concord, Worden, Elvira, Martha, Moore's Early, Moore's Diamond, Catawba, and several of the Rogers's. Have discarded all varieties but four. A leaf-louse destroys the foliage on all the wrinkled-leaf varieties. Rogers's not hardy; Martha not a good bearer. Would recommend Concord, Worden, Moore's Early, and Moore's Diamond. I have never experimented very much; grubbed out most all my Catawba, Elvira, Rogers's, etc.; left only enough for home use; then planted Concords, as I wanted some pay for my work. The Concord is the only moneymaker. I prefer one-year-old vines, set $7 \times 10$ feet; cultivate with a diamond plow and a five-toothed cultivator. Prune early in the spring, when heavy frosts are over, and pinch the vines after the fruit is well set, and prune in July, if the growth is very rank. My trellis is made of three strands of No. 9 or No. 12 wire and posts twenty feet a part. I have bagged my grapes -4000 bunches in two years; I would advise it, if help can be had cheaply. The heavy rains ruined the bags, and the fingers of my helper were too stiff to leave me any profit after paying him one dollar per day. [Girls are more nimble.] Gather each bunch carefully, and pack in eight-pound baskets; sell mostly at home and to shippers here. Realized from twenty-five to fifty dollars per acre last year; about every fifth year I have to buy grapes to eat. Two of the largest commercial vineyards here have been grubbed out. I do not consider them a paying crop; would rather grow corn. I have put up unfermented grape juice, but do not now, as it is too much labor.

W. J. Griffing, Manhattan, Riley county: Have one-half acre of grape-vines, planted on upland clay loam. My varieties are Concord, Worden, Etta, and Dracut Amber. Plant two-year-old vines. Set six feet apart in the row, rows six feet apart. Till with a one-horse, double-shovel-cultivator. Prune in late winter or early spring; would prune in the summer if I had time. My trellis is hedge posts and wire. Do not bag the fruit; it is well to bag a few. I prefer ten-pound baskets. Market at Manhattan. They are too easily grown and too prolific to be a paying crop. I put up unfermented grape juice; we can it every year as you would can fruit; we like it sweetened and diluted with water in the summer; it is as good as lemonade. We also can cherry and blackberry juice in the same way for the same purpose. Often use it to make jelly in the winter.

Sam Kimble, Manhattan, Riley county: I have between 300 and 400 grapevines, planted on an acre of clay upland, sloping slightly to the southeast. Hare tested Concord, Worden, and Delaware. Would recommend Worden as best of all, as it is as hardy as Concord, a little larger berry, and sweeter. I think it finer for table use. Have tested the Delaware experimentally, but find it unprofitable, as it is not hardy here. I plant two-year-old, well-rooted vines, six to eight feet apart, in rows nine feet apart. Till with a five-tooth cultivator lightly to keep the ground clean and loose, but not deep enough to tear the roots. Thorough cultivation is half the battle. Prune late in winter, and again about June 15 I prune off the long shoots with a scythe; again in summer I prune along the sides of the trellis with a sickle. I use a five-wire-fence trellis, which I think is best. Have not bagged any, as I do not think it beneficial. Cut bunches with sharp knife or shears. I let my neighbors and friends come and get all they want free. Some pay me one dollar a hundredweight when they get 
a large quantity; have averaged for the last two years about thirty dollars in cash per year. They are a big-paying crop, both in money and satisfaction. We intend putting up some unfermented grape juice this year. My crop of 1898 was fully 5000 pounds; 1899 was 3000 pounds; and this year [1900] I think it will be 3500 pounđ̄s.

A. G. Axelton, Randolph, Riley county: Have 200 grape-vines growing on black loam mixed with gravel, sloping to the northwest. My varieties are Concord, Elvira, and twenty others ; would recommend the two named. I plant oneyear-old vines, $7 \times 8$ feet; till with a corn cultivator and five-hoe cultivator; prune in the spring; never eummer prune-have n't time. My trellis is made of posts, set sixteen feet apart, and four wires. Do not bag my grapes. Cut them with shears. Sell in home market.

W. R. Newman, Hargrave, Rush county: Grapes are not a success here yet; but the climate is becoming more humid. We tried grapes a number of years ago, and, by mulching and good cultivation, kept the vines alive a few years. Wild grapes do fairly well along the creeks, where they are protected by high banks. I believe, with good protection and plenty of water, grapes would succeed here.

B. E. Mrrick, La Crosse, Rush county: Have twenty-five grape-vines, planted on good, dry, upland soil. Set one-year-old vines, six feet apart; prune early in the spring, with a knife; pinch the green shoots in the summer if they are making too rank a growth, and to season and mature the vines. My trellis is smooth wires, on posts fourteen feet apart. Till with a cultivator and hoe; do notmulch. Have tried Concord and Niagara; discarded the latter, because it is too tender to stand the climate; would recommend only Concord for this locality. My vines have been set but one year; therefore are not yet in bearing. I consider them a paying crop for home use, but would not advise extensive planting of them.

John H. Manners, Luray, Russell county: I grow only a few grapes for family use, planted on a northeast sloping depression, which I think best, as they are little exposed to the sun and wind. Plant two-year-old roots. Prune close in the spring, before the sap starts. I trellis the vines near the ground, so as to protect them from the wind. Cultivate with a spade and hoe, if you have only a few. I do not mulch, but keep a dirt blanket around the vines. Have tried only Concord, which I would recommend for this locality. They are a paying crop here, and I would advise planting them for family use, at least. Have never sacked the fruit. Comparatively little effort has been made here to grow the grape. The wild grapes cling to our hillsides, particularly northern exposures; they have never been known to summer- or winter-kill. We have but little difficulty in getting the tame varieties to grow here; they bear good crops as soon as old enough. Hail-storms and grasshoppers sometimes destroy the vines. It has been demonstrated that they will bear and do well in this valley, and that for quality and quantity we have no reason to complain. The trouble lies largely with ourselves. Some have natural barriers against these vine destroyers; others could soon prepare them; these are hillsides, slopes, walls, and hedges. The day is not far distant when everybody here will have all the grapes and small fruits they need for family use.

B. F. Haines, Russell, Russell county: Would plant yearling vines, eight feet apart, on land sloping to the northeast. Prune during the latter part of March and in the summer. Stone posts and wire make the best trellis. Cultivate with a hoe or plow, which I think best for the work. Mulch the second 
year. Have tried Concord, and many other varieties. I would recommend the Concord for this locality, as it is the most satisfactory. Consume all the fruit at home. They are a paying crop, and I would advise extensive planting. Have never sacked grapes.

F. G. Barker, Salina, Saline county: I have nine acres of grapes growing on upland; think slope makes no difference. I planted first-class one-year-old vines, $10 \times 10$ feet, but think $8 \times 12$ would be a better distance. I prune to about ten fruit-buds to each vine; I also prune during summer; walk down between the rows and cut back the rampant growth with a corn-knife. For a trellis I use one wire running east and west, one and one-half feet from the ground. I cultivate with a twelve inch plow and a disk harrow, which I consider best. I use a home-made rake to remove the vines from between the rows after pruning. I mulch my vines. I have tried Concord, Elvira, Delaware, Iona, Wyoming Red, Pocklington, Niagara, Worden, Ives, Moore's Early, Catawba, Clinton, America, and Massasoit. Have discarded all the fancy and wine varieties, as the buyers do n't know any variety but the Concord, and they will buy ten baskets of Concord to one of Delaware, at the same price. Those which do best here are Massasoit, Worden, Catawba, and Ives. I would recommend Massasoit and Concord for this locality. I gather in eight-pound baskets, and do not repack before marketing. Sell part in the vineyard, and the balance in neighboring towns. I do not consider them a paying crop excepting for home use, and would not advise extensive planting here. I have sacked grapes for exhibition purposes, but it will not pay in a commercial way, as the dealers will not pay for fancy grapes. We put up unfermented grape juice; we boil the fresh juice, skim, and put into black quart bottles, drive cork in with hand corker, pour hot wax on the cork, and, when cool, we dip the cork end of the bottle in hot wax. While making, have everything hot, and then afterwards keep in a cool place. I buy bottles at the soda-fountains, at $\$ 3.50$ per 100 .

Henri Foner, Salina, Saline county: I have an acre and a half of grapevines growing on black loam which is slightly sandy. I prefer a south or east slope. Set two-year-old vines, $6 \times 8$ feet. I prune in March, and then in June, after the grapes are set; I break [?] the rest. I use three wires and posts for a trellis. Cultivate with a plow, in May, by turning the ground away from the vines, and in June I turn it back; a plow is the best implement for this work. I mulch once every three years. I would recommend Concord for this locality, as this country is too windy for other varieties. I sell the fruit at home, to farmers, receiving $\$ 200$ per acre. They are a profitable crop, and I would advise extensive planting here. Have never sacked the fruit, but think it would be very beneficial. We put up unfermented grape juice; boil it one minute and seal up.

A. W. Jones, Salina, Saline county: Have about 350 grape-vines, planted on sandy soil, which I prefer; the slope I think is not important. Have about forty varieties. Have tried and discarded Champion as poor quality; Goethe, Brighton, Salem, Agawam, Pocklington and Prentiss as too tender. Would recommend Concord, Catawba, Lindley, Martha, Worden, Telegraph, and Elvira : the latter one for jelly. Plant one-year-old vines, $8 \times 9$ feet. Till with a plow, a cultivator, and a harrow; keep the ground clean. Prune the latter part of winter by thinning out the canes and cutting back to two or three buds; summer prune some. My trellis is made of posts and wire. Do not bag grapes for market, and would not advise it; it is too expensive. Cut the bunches from the vines and pack in eight-pound baskets. Market at Salina; at present prices the 
profit is very small. We formerly had five or six times the number of vines we now have, having marketed as high as 38,000 pounds in a single season; but owing to droughts, late frosts and prevailing prices of the past few years, we have grubbed out most of our vineyard.

Frank Jurgens, Scott, Scott county: I have eighty grape-vines growing on very fertile, dark soil which is level. The varieties are Champion, Concord, Catawba, and Niagara. My Niagaras froze down. Would recommend Champion and Concord. I plant one-year-old vines, six by eight feet; cultivate with a hoe and spade. Prune in February; I prune some in summer, when the shade gets too dense. My trellis is posts set in the ground with crosspieces. Gather the fruit by hand in ten-pound baskets, and sell at Scott. I consider them a good, paying crop. Have put up unfermented grape juice; boil, drain juice out, heat, bottle, seal.

A. C. Hrll, Liberal, Seward county: I have 100 grape-vines growing on sandy soil. An eastern slope is preferable. Set one year-old vines, six feet apart. Prune in February; also during summer. I till with a plow and hoe, but a disk harrow is the best implement for this work. I mulch my vines. Have tried Concord, Martha, and Lady Washington. Have discarded Lady Washington, as it is too small. I would recommend Concord for this locality, as it is the most satisfactory variety. They would pay well here if irrigated; and I would advise extensive planting if they could be treated this way. Have never sacked the fruit.

William RAPP, Liberal, Seward county: I have 250 grape-vines growing on a southern slope. Set one-year-old vines, $6 \times 8$ feet apart; prune closely, in March, also during summer. Use a wire trellis. Cultivate with a double-shovel or a small stirring-plow; I mulch my vines. Have tried Concord, Martha, and Catawba; I would recommend the two former ones, as they do best here. Grapes do as well here as any other fruit; they bear well, but the grasshoppers bother them. Have never sacked the fruit.

G. W. Collings, Wichita, Sedgwick county: I have grown grapes for home use for twenty-five years, but my experience with a commercial vineyard began only three years ago. Since that time I have had control of an old vineyard of three acres, and at the same time began to put out a new one. The new vineyard now has in it 2500 vines; some have been set each of the three years. The old vineyard is mostly Concord; there are a few other varieties in it, among which are some Salem. These make an excellent growth of wood, and when the fruit comes to maturity, and is well ripened, it is one of the best of grapes; large and showy, in both bunch and berry, and of exquisite flavor; but with me these vines have ripened very little sound fruit. The fruit has been affected every year by anthracnose, and two crops were almost entirely destroyed; whether or not this disease could be controlled by spraying, I do not know.

Only a part of the new vineyard has borne fruit; last year there were a few bunches on the following varieties: Moore's Early, Concord, Brighton, Niagara, Pocklington, Goethe, Delaware, Catawba, and Worden, all of which promise to do well when the vines are older. In addition to the above, I have out the following varieties: Campbell's Early, Cynthiana, Green Mountain, Moore's Diamond, Salem, and Cottage, and I have lately added a McPike and an Ozark. All of the above have made a fairly good growth excepting Campbell's Early. Two vines of this variety that have been out three years, and had the best of care, have not grown a cane two feet long. The land on which this vineyard is growing is black loam, some parts having a little sand in it, but the most of it is 
entirely without sand. There is no perceptible difference in the growth of vine or fruit between those grown on sandy land or on land containing no sand. There is, however, a considerable difference in the working; one has to have more "sand in his craw" to work where there is no sand in the soil. My land is nearly level; only sufficiently undulating to prevent water standing on any part of it; I therefore have had no experience with slopes. My first year's setting was all of one-year-old vines; since then have used two-year-old vines; the difference in cost is so little that it pays to buy two-year-old vines. I propagate some of my vines, both by cuttings and layering, and these are set in the fall, with very satisfactory results. For the sake of uniformity, the vines are all set eight feet each way. I prune any time after the leaves fall in the autumn until the sap begins to flow in the spring. I have no hard-and-fast lines for pruning, but aim to get rid of as much old wood as possible, leaving enough new wood to bear a crop, and some spurs near the ground for renewal. I do very little summer pruning.

I made a trellis by setting the posts sixteen feet apart along the rows, putting on two No. 12 galvanized-iron wires. For cultivating a one-horse plow is a very useful tool. With it you can run shallow enough not to interfere with the roots, and can throw the dirt to the vines so as to cover all the weeds in the row, and so that hand hoeing is not necessary. The next time the earth must be worked back, and the land-side of the plow will have to go next to the row, and quite a little space will be left; part of this can be reached with a five-tooth cultivator; but there will still be a part of it that nothing but "the man with the hoe" can reach. Take an ordinary hoe to a blacksmith and have the shank straightened, so that you can use it like a shovel, and you will have a tool that will be much superior to an ordinary hoe for this work. A two-horse cultivator is sometimes used for working the middles, but the wheels of this implement prevent going close to the vines. No one tool is best; each has its uses. As a general rule I do not mulch, but with varieties that are liable to winter-kill, such as the Goethe, I sometimes put the vines on the ground and cover with straw or strawy manure. The fruit is picked in half-bushel baskets and brought to the packing shed, and all the overripe and inferior berries are picked out. The packing is done in eight-pound baskets, and if the grapes are to be shipped the baskets are covered, but if for the local market covers are not used.

I sold the most of my grapes three years ago to commission merchants, for shipping. Since then the most of them have gone to the local market. When Moore's Early first appears in the market the price starts at about forty cents per eight-pound basket, and by the time the Concord harvest is at its highest tide the price goes down to ten cents. When we could sell the most of the crop in large quantities for shipment grape growing paid handsomely; but since then the demand has become so small, the local market overstocked, and, with the consequent low prices and the yearly increasing depredations of the birds, the balance is apt to be on the wrong side of the ledger. I tried sacking the fruit when I had only enough for home use, and found it a complete protection from the birds and insects. Have not tried it in a commercial way, but if it will pay to grow grapes at all it will surely pay to sack them. For two years past the ravages of the birds have been appalling to the grape grower. Some of my neighbors shoot the birds, but this is expensive, and, as the birds that do the mischief are migratory, shooting seems to do little good. If the money spent for shooting material was used in sacking the grapes the results would doubtless be far better. There are now more than enough grape-vines growing in this vicinity to supply the local demand, and if some other market cannot be found I 
would not advise extensive planting. Growing grapes has a great fascination for me, and I regret that the profits are not greater. We have put up unfermented grape juice for family use; take the juice from good, ripe grapes from which all green and otherwise bad berries have been picked; strain it, heat to the boilingpoint; skim thoroughly, and seal in bottles reșting in a vessel of hot water. Glass fruit-jars may be used instead of bottles. Everything that comes in contact with the juice must be scrupulously clean, and the juice should be sealed as soon as possible after being expressed from the grapes.

A. H. Buckman, Topeka, Shawnee county: I have 2500 grape-vines growing on soil which would be good corn land. It slopes only enongh for water to run off without washing. Have tried fifty varieties; have discarded forty of them, because of tenderness, poor quality, rot, etc. There are six varieties which I would recommend; they are Moore's Early, Concord, Worden, Green Mountain, Woodruff Red, and Goethe. I prefer choice one-year-old vines for setting - home grown, if possible; set them eight feet apart in the rows, and the rows ten feet apart. Cultivate shallow, with a five-hoe or harrow-tooth cultivator. Prune in February, while they are dormant. My trellis is made of hedge posts, sixteen to twenty feet apart, and three No. 12 wires. I do not summer prune, but pull off all useless sprouts, as it appears to weaken the vitality of the vines. Have never bagged my grapes; I would advise it for exhibition purposes, but I do not grow grapes for exhibition. Market in five- to ten-pound baskets, in Topeka. I realize from forty to fifty dollars per acre. I consider them a paying crop for the amount of labor required.

S. R. Johnston, Wakarusa, Shawnee county: I have 110 grape-vines, planted in sandy soil having a clay subsoil. I do not think slope makes any difference. Plant two-year-old vines, eight feet apart. Prune closely in the fall; do not prune during the summer. My trellis is made of hedge posts and wire. Till them with a plow and spading-fork. I mulch in the fall, and scatter the mulch in the spring. I have tried Concord, Niagara, and Pocklington; have discarded Niagara, which winter-killed in 1898. The Concord does best with me, which I would recommend for this locality. I gather and market in twenty-five-pound baskets; sell at four cents per pound. I think they pay, and would advise planting extensively. Have never tried bagging the fruit.

T. J. Brewster, Lucerne, Sheridan county: I have thirty-six grape-vines, planted on upland loam having a hard subsoil. A northeast slope is preferable. Set yearling vines, $3 \times 8$ feet. Prune in February. I have used a wire trellis, but think a roof [three parallel wires above the vines] trellis six feet high would be more satisfactory. I cultivate by turning the soil over with a fork. I do not mulch, but irrigate my vines from a well. Have tried Concord and Clinton; discarded the Clinton, because of poor fruit and numerous sprouts from the roots; would recommend Concord and Worden, as they are the most satisfactory in this locality. I think they would be a paying crop, and believe, if the people understood growing them, they would be planted extensively here.

M. E. Welcs, Smith Center, Smith county: I set 300 grape-vines in 1883 on an eastern slope of yellow clay having a silt subsoil; they lived six or seven years, then commenced to die out, and in ten years they were all gone. A twig-borer that works in the joints apparently used up many; some died with scabby roots. The Catawba grew best, bore best, and lasted the longest. I set two dozen this spring ( some new-fangled varieties that I bought of a tree pedler - the first bill of goods I ever bought of a tree agent). I have mulched, but don't think it best. Shallow culture, keeping the ground clean and nearly level, is the best treatment; 
prune before the sap starts in the spring; do not prune the green twigs. I do not consider them profitable. In putting up unfermented grape juice, we set the cans in cool water and let come to a boil; then seal, while hot.

D. H. Welch, Macksville, Stafford county: I have 700 grape-vines growing on dark, sandy soil. Plant No. 1 one-year-old vines, $6 \times 10$ feet; prune to two canes in February; also prune some during summer. My trellis is made of wire. Care for them with a five-tooth cultivator, which I think is best. Do not mulch them. Have tried Pocklington, Concord, and Worden; have discarded none, but find the Concord has done best so far, and would recommend it for this locality. Gather in pails and boxes; dispose of them in our home market. I consider them a paying crop. Have never bagged the fruit. The main thing here is to cultivate almost constantly, after each rain, and between rains to keep the weeds down, or the 'hoppers will cut them off. Have put up unfermented juice; I can it just the same as fruit.

W. M. Campbell, St. John, Stafford county: I have only a few grape-vines, planted on creek bottom. Set two-year-old vines, six by eight feet. Prune in winter. Use a three-wire trellis; but stakes are better, as they allow regular ripening. Cultivate with anything to keep the soil loose on top. Do not mulch. Concord and Moore's Early do best here. Have never sacked the fruit. The above-named varieties do well here with almost any kind of culture. We could raise grapes by the million crates, if we only had a market for them.

H. E. Pelton, St. John, Stafford county: I have sixty grape-vines growing on level, sandy soil. Set two-year-old vines, twelve feet apart, in rows fifteen feet apart. Prune in February; also a little in summer. For a trellis I use posts and wires running lengthwise of the rows. Cultivate with a disk harrow; I think that tool best. Do not mulch. Have tried Concord, Moore's Early, Niagara, Worden, Agawam, and Isabella. Have discarded none. I would recommend Concord and Moore's Early, as they are the most successful here. Gather the fruit in baskets; sell in local markets, receiving four cents per pound for the early grapes, and three cents per pound for the late ones. I do not consider them a good, paying crop, and would not advise extensive planting. Have never sacked the fruit. My first planting was all Concords, which killed back to the ground every winter for five or six years; they finally made a good growth, and have done fairly well since, and the last two years have borne reasonably well. Three years ago I planted Concord and Moore's Early; both varieties bore some fruit the second season, and were well loaded last season. The other varieties are not yet in bearing.

E. T. Wrighr, Seward, Stafford county: I have a quarter of an acre of Concord grapes, planted on a dark, sandy loam sloping to the east; the vines are set six feet apart in the row, and the rows eight feet apart. Cultivate with a fivetoothed harrow; prune in February; cut back to two buds; my trellis is of posts and two wires. I do not summer prune, as I like lots of leaves and vines; the birds do not eat the fruit so badly. Have never bagged grapes, but would advise it, as the bags would protect them from the birds. Gather them in baskets.

C. E. VAN METER, Johnson, Stanton county: My vines were set out this spring (1901) on sandy loam. I prefer a northern slope. Set yearling vines from cuttings, about eight feet apart. Pruning should be done closely during winter. For a trellis, I use single stakes five feet high. Till with a cultivator and hoe. A five-tooth cultivator is the best tool. I think mulching advisable. Have tried only Concord, but almost any variety will do well here after it is once started, 
but they need irrigation at the start. They are a very profitable crop. I would advise extensive planting here, if fixed so you can irrigate, which can be done from wells. Have never sacked the fruit. The large fox grape grows wild on the Cimarron river south of here.

D. M. Adams, Rome, Sumner county : I have about one-eighth of an acre of grapes, planted on level land, which are Concord, Agawam, Catawba, Martha Washington, and Worden. Would advise planting the above list, excepting Worden. I prefer one- or two-year-old vines, set eight feet apart. Cultivate with a horse cultivator. Prune during the winter, usually in February. My trellis is posts and two wires. I never summer prune. Have bagged a few bunches to protect them from the birds. Birds are our greatest drawback.

Geo. W. BaIley, Wellington, Sumner county: I have 400 vines, on upland having a southern slope. The varieties are Concord, Worden, Moore's Early, and I recommend them all. Plant one-year-old vines, eight feet apart each way. Cultivate with a one-horse cultivator. Prune late in the fall. Use a two-wire trellis. I do not summer prune-want the leaves to protect the fruit from the sun. Have never bagged any. Market them at home. Think they pay. Have never had a failure of grápes since my first crop, in 1874.

IsAaC Flood, Colby, Thomas county: I have twenty-four vines growing on bottom land sloping to the north, which I think preferable here. Set two-yearold vines, $8 \times 8$ feet. Prune during summer to remove suckers and shorten back. My trellis is posts and smooth wire. A five-tooth cultivator and one-horse plow are the best implements for tillage. Do not mulch. Have tried Moore's Diamond, INiagara, and Concord; discarded all but Concord, as they were too tender. I would recommend the Concord for this locality. I have none for market. Theyipay in the pleasure of seeing them grow. Would not advise extensive planting here.

M. L. LACEy, Colby, Thomas county: I have only ten vines, planted on clay loam. Set two- or three-year-old vines. Prune any time from November to February. Have tried Concord, Moore's Early, Brighton, and Niagara. Am going to put out some two-year-old Concords this spring [1901].

, Colby, Thomas county: I have six vines, planted on level upland; the vines need a windbreak to protect them, as so much wind wears them out. I have planted several times, and find that young vines live best. Set them six feet apart. Prune in February, leaving two buds. I find slats and posts make the best trellis. Cultivate with a hoe, to keep the weeds down. Do not mulch. Have tried Concord; I do not consider them a paying crop here, and would not advise extensive planting. I have never sacked the fruit, but think it would pay, as the grapes always set well, but the grasshoppers and insects eat them up before they mature. I irrigate my vines.

E. W. O'Toole, Collyer, Trego county: I have about fifty grape-vines, planted on a southern slope. My variety is Concord. I would recommend only hardy varieties. I prefer two-year-old vines, planted four feet apart. I mulch my vines. Prune them the first of April. My trellis is three feet high.

G. T. Galloway, Wa Keeney, Trego county: I have 175 grape-vines growing on level bottom land; they are Concord, Niagara, and Pocklington; would recommend higher land, as the spring frosts kill the crop. Prefer one-year-old vines, set $8 \times 16$ feet. Cultivate with plow and harrow. Prune in February. 
Trellis is made of posts and two or three wires. I never tried summer pruning. Do not bag them. Market my grapes at Wa Keeney. I do not consider them a paying crop on bottom land.

C. C. Cоoк, Bradford, Wabaunsee county: I have 100 grape-vines growing on upland having a northeast slope. My varieties are: Concord, Niagara, Moore's Diamond, Moore's Early, Pocklington, Worden, Ives, Clinton, and McPike. The Ives may not be true to name; I would recommend all the varieties named except Ives. I have been experimenting with McPike, which had forty bunches on a vine three years old. I put out in spring of 1898 a oneyear-old McPike grape-vine; last spring (1900) I trimmed it to one arm, and it broke forth in fourteen shoots, and, on July 28, was carrying forty fine bunches. I plant one-year-old vines. Set them eight and ten feet, in single rows, in the orchard. Cultivate with a disk and five-tooth cultivator and double-shovel. Prune when the vines are dormant, leaving two eyes to the cane. My trellis is of wire, on six-foot posts. Summer prune when there is an excessive growth and danger of the crop being robbed. Never bag my grapes, as the market will not warrant it. Gather by snapping off the bunches. Market in twenty-pound baskets, and sell at home. I consider them a paying crop. I have put up unfermented grape juice and shall put up some this year. Press the grapes in a cider-mill, and boil, skim and seal up the juice without sweetening.

C. C. Gardiner, Bradford, Wabaunsee county: I have 1200 grapes in Shawnee county and 200 in Wabaunsee county, planted on black loam having a southern slope. My varieties are Concord, Catawba, Dracut Amber, and Clinton. Have discarded Catawba because it was not hardy, Dracut Amber not fruitful, Clinton was too poor. Would recommend Concord, as it is hardy, prolific, sure to bear, and reliable. Would plant one- and two-year-old vines, $8 \times 10$ feet; till with a cultivator and hoe. Prune in the spring, just before the sap starts. My trellis is of posts and smooth wire; the top wire is five feet from the ground. I do not summer prune; I do not consider it necessary, and think the leaves are needed to help mature the fruit. Have never bagged the fruit, and would not adrise it, as we get good enough fruit without, and it would not pay. I cut with shears, and place in ten- to twenty-pound baskets, and market at home; people come for them. They do not pay well, as a rule. I have put up unfermented grape juice; press the juice from the fruit, heat, and hermetically seal.

C. H. TAYLOR, Eskridge, Wabaunsee county : I have one-half acre of grapes, planted on limestone land sloping to the northeast. Varieties tried are Concord, Moore's Early, Niagara, Ives, Delaware, Catawba, Dracut Amber, and Worden. Have discarded all excepting the three first; they are tender and unproductive. Would recommend Concord, Moore's Early, and Niagara. Plant strong oneyear-old vines, eight feet apart; cultivate shallow, with five-tooth cultivator and harrow. Prune in December and January, and some in summer, to promote growth and ripening of fruit. My trellis is strong wire. Have bagged to protect specimens, but do not advise it, as it is too expensive. Cut with long stems and handle carefully; pack in shallow boxes; market at home, or local markets. They aggregate $\$ 150$ per acre; I consider them a fairly good, paying crop. I sometimes put up unfermented grape juice; press the juice from fresh grapes and seal scalding hot in bottles or jars.

M. T. Griggs, Wallace, Wallace county: I have only fifteen vines, planted in nice sandy loam on high land, sixty feet to water. Have had very good success with the Concord. Plant two-year-old vines, eight to ten feet apart. Cultivate 
with a harrow and hoe. Prune in February; have not summer pruned for lack of time. I think a trellis made of lumber best. I consider them a paying crop. My vines were full this year and the bunches fine; but the grasshoppers came, and they seem to be fond of grapes, for they ate them up. [Why not try bagging ?]

J. B. Avery, Clifton, Washington county: Have 800 grape-vines, planted on a southern slope; they are Concord, Worden, Elvira, Moore's Early, and about twenty others; I would recommend first Concord, then Worden. I prefer strong one-year-old vines, planted eight feet apart; cultivate with Planet Jr. horse hoe; prune in spring, just before the sap starts. I summer prune only a little, from lack of time. I prefer eight- and ten-pound baskets for marketing. I sell at Clifton. I do not consider them a paying crop when time and expenses are counted.

William Yound, Brantford, Washington county: I have a half-acre of grapevines, on eastern and western slopes. I have Concord and some other varieties; I prefer the Concord. I prefer one-year-old layers, planted six feet in the row, and the rows eight feet apart. If I was planting a new vineyard, I would set them $6 \times 12$ feet, so they could be cultivated more easily; use a two-horse cultivator. Prune any time during winter when they are not frozen, or any time in the spring before the sap starts. I have a three-wire trellis. I never prune in summer, as the sun would burn the fruit. Have never bagged grapes; think the cost would overrun the profit. Cut the bunches with a knife, and market in twohandled baskets at Clifton and neighborhood. I think them a good, paying crop.

A. E. Houghton, Linn, Washington county: My soil is level, black loam. Raise Concords for family use only. I would recommend this variety, as it is the only one I have tried. Set two-year-old vines, eight feet apart each way. Have been mulching them, but would not recommend it. Prune in February, with pruning shears. My trellis is made of posts and wires. Summer prune the vines when I have time, as I think it throws strength into the grapes. Have never bagged any, but think it a good, thing. It would protect them from birds and give them a better flavor. In gathering, I cut the bunches with small pruning shears and lay in baskets. Think them a good, paying crop. I think it best to cultivate the ground and keep it clean and loose, on account of crab-grass. I mulch mine, but that brings the roots too near the surface.

Thomas Brown, Palmer, Washington county: I have 300 Concord grape vines, planted on a stiff, black soil. Would recommend this variety, with which I have had good success. Set my vines ten feet apart. Mulch in the spring. Prune in the spring before the sap starts. My trellis is of posts and wire. Have never bagged my grapes. Gather in twenty-five-pound baskets and market at home. Receive one and one-half to three cents per pound. I consider them a good, paying crop. My vines were all killed down two years ago, but I cut them off at the ground and they have made fine growth this year and have a few grapes. They had borne well for the last fifteen years. I think the Concord our best grape, and a sure bearer in Washington county.

G. M. BAUM, Washington, Washington county: Have fifty grape-vines growing on sandy loam having a slight slope to the east. Am growing all the leading varieties; Concord is the only variety that has paid me; have experimentally tried Victor, Moore's Early, and Niagara, but they were not satisfactory. I plant two-year-old vines, $8 \times 8$ feet; cultivate with a hoe; prune with a pruning-knife in February, and again in summer, directly after the fruit has set, and pretty 
close at that time; and do not touch them afterwards, so as to weaken necessary shade. My trellis is made of wire; drawn as tightly as possible. I have not bagged my grapes, but would advise it, as I think the fruit better, particularly if season is dry. I think them a paying crop. Have put up unfermented grape juice; bring the grapes to boiling-point, and skim; put a tablespoonful of sugar to a quart of juice, and seal up in glass cans. Do n't think it a good plan to cultivate between the rows more than once every two years; then hoe, and keep every weed down. Grape roots are so near the surface, and extend out so far, that I don't think it a good plan to tear them up and expose roots too often. However, if not too heavily fruited, give the ground a good tearing up every other year, and keep always perfectly free from weeds.

F. SeIferth, Strawberry, Washington county: I have about 650 grape-vines, planted on land which slopes gradually to the east. My varieties are Concord, Elvira, Ives, and Clinton. Would recommend Concord and Elvira. I prefer two-year-old vines, set six feet square. Prune in February and March. My trellis is of posts and three wires. Sometimes I summer prune, clipping the ends if they are growing too rank, but this is seldom. Have never bagged the fruit. Gather in twenty-pound baskets, and market at home. Have realized $\$ 100$ and over per acre. I consider them a paying crop. I mulch my vines with prairie hay, which lasts two years; then I rake the mulch in to the vines and cultivate with a hoe one year; then give them a good mulching again. I have good success and raise a full crop almost every year; my vines are always in good condition; grow from eight to fourteen feet during a season. Have an immense crop this year (1900) - large clusters and large berries.

John C. Ford, Leoti, Wichita county: I have only a few Concord grapes, which have just commenced bearing. They are planted on level land. I think grapes would be a success here if we irrigated them.

R. O. Graham, Altoona, Wilson county: I have 150 grape-vines, planted on sandy loam having a clay subsoil. I think slope makes very little difference, but northeast is preferable. Set the young vines $8 \times 10$ feet. Prune severely in February; also pinch them back during the summer. I use a wire trellis. Cultivate with a spade and hoe, and keep them mulched with straw; a plow and corn-cultivator are the best implements for this work. Have tried Concord and Niagara, which do well here; the former is preferable. Pick by hand into the baskets in which they are to be marketed; sell at home, usually receiving from three to four cents per pound; and sometimes five cents, for green ones. They pay fairly well, but I would not advise very extensive planting. Have never sacked the fruit.

John A. MAGILL, Roper, Wilson county: I put out one and one-half acres of grape-vines several years ago on red soil, but have let them run down. I think slope makes a difference; a southeastern is preferable. Set yearling vines, six feet each way. Prune to one bud. For a trellis I use stakes two feet high. Till shallow, with a five-toothed cultivator. Do not mulch. Have tried Dracut Amber, Concord, Clinton, Delaware, and Norton's Virginia. Have discarded all of these excepting Concord, for want of a good market, as we depend on our home market, where we receive from one and one-half to two cents per pound. I do not consider them profitable, and would not advise extensive planting here. Have never sacked the fruit.

A. J. Jones, Yates Center, Woodson county: I have forty grape-vines growing on sandy soil. I think an eastern slope best. Set one-year-old vines, six feet 
apart; prune early in the spring; use posts and wires for a trellis; cultivate with a double-shovel plow and a hoe; do not mulch. Have tried Concord, Niagara, Clinton, Delaware, Goethe, and Moore's; have discarded Clinton, as it is poor-flavored. Concord is the best variety for this locality; I would recommend it and Goethe and Niagara. I would not advise extensive planting here unless the culture and weatber improve. Have tried sacking the fruit and think it pays. We put up unfermented grape juice; can it in fruit cans. Prospect for grapes in this county seems to be good. More systematic culture of grape-vines would improve the growth. I think the soil and climate adapted to grape culture, but our people need more education along this line.

A. Chandler, Argentine, Wyandotte county: I have six acres of grapevines growing on clay upland. Prefer an eastern slope. Set yearling vines, $7 \times 8$ feet. Prune in November, to three canes. I also prune the rank growth during summer, beyond the fourth leaf. Use a three-wire trellis. Cultivate my vines shallow with a plow and seven-tooth harrow; a five-or seventh-tooth cultivator is the best implement for this work. Do not mulch the vines. Have tried Champion, Worden, Moore's Early, Concord, Niagara, Moore's Diamond, Delaware, and Wyoming. Have discarded Champion, Hartford Prolific, and Delaware, as we have better varieties than these. Moore's Early and Concord do best here. Use eight-and eleven-pound baskets for marketing the fruit in; the latter is preferable; sell in Kansas City, receiving one and one-half to two cents per pound for them. They are profitable, but I would not advise extensive planting. I have sacked the fruit, but not to any extent; it would pay at two and one-half cents per pound. We put up unfermented grape juice-first press out the juice and then heat to 200 degrees and seal tight.

W. D. Cellar, Edwardsville, Wyandotte county: Have one acre of grapevines growing on clay subsoil sloping to the east. They are Concord, Elvira; Goethe, Champion, Dracut Amber, Moore's Early, and Worden. Will discard Elvira and Champion - poor quality; Goethe, not hardy; and Draçut Amber, not productive. Would recommend Concord, Moore's Early, and Worden. I set one-year-old vines, $8 \times 8$ feet. My vineyard is seeded down to clover and has been for four years. Prune any time in winter ; cut away all I dare, "and then some." Do not summer prune. My trellis is wire. Cannot afford to bag my grapes. Hire girls to cut my grapes, at one cent per eight-pound basket. Market in western Kansas and Colorado, realizing all the way from nothing to fifty dollars per acre. I have a neighbor who has made it pay. Grapes are rotting badly in this locality this year (1900), probably due to excessive rain.

MaJ. Frank Holsinger, Rosedale, Wyandotte county: I have seven acres of grapes, planted on clay and second-bottom alluvial soil. Some are on an eastern and some on a southern slope, and some on the hilltop, but can see no difference. Set one-year-old vines, $8 \times 8$ feet apart. Prune during the winter, when I can do little else, by leaving not more than three vines for bearing. Have pruned during summer, but see no good results. Don't think it pays. My trellis is made of seven-foot posts and No. 12 wire. Till them about the same as I do corn, with a double-shovel or common cultivator. Do not mulch. Have tried Concord, Worden, Moore's Early, Champion, Catawba, Early Ohio, Delaware, Elvira, Wyoming Red, Hicks, and Niagara. Have discarded all excepting Worden, Concord, Champion, and Moore's Early, as they were unprofitable for market. The Concord, Moore's Early, Worden and Champion do best here, and I would recommend the same for this locality. Gather in peck baskets, and sell in open packages from the wagon on public square in Kansas City, Mo., realizing 
from one to five cents per pound. They pay even at two cents, as they are a sure crop. I would advise planting extensively if you live near enough to market to reach it with your own team. I have used paper bags for several years past, on account of the birds, insects, and rot; could not succeed without. The grapes should be sacked soon after the blossoms fall - the sooner the better-or bacteria germs get possession and the grapes are likely to scab and rot. Many fail because they defer too long before putting on the sacks. We put up unfermented grape juice by pressing out the juice, bring to boiling-point, and hermetically seal. Use glass jars-little trouble and no loss. Juice thus kept is healthful and palatable.

\section{GRAPE GROWING IN SOUTHERN KANSAS.}

By P. C. Bowen, Cherryvale.

Experience during the last twenty years with the grape has taught me that only hardy varieties can be successfully grown in this part of the state with profit to the producer, and then on specially favorable locations; high, rolling, sandy, or gravelly soils, overlooking large bodies of water (the larger the better), are much the best. Before planting, the soil should be deeply and thoroughly plowed and subsoiled as deeply as possible, and only the most hardy varieties, those usually termed "iron-clads," are preferable; black grapes are best and most satisfactory, giving uniformly good results. Good, strong two-year-old plants only should be used in setting the vineyard, after which it should be thoroughly and frequently cultivated all of the first season after transplanting, the tops allowed to grow as they please, and only pruned after the leaves have fallen and the sap has gone down into the roots in the following fall or winter, when they would be cut back to three canes containing several buds each; two for side arms, on opposite sides, and one for an upright cane, in the center. During the following winter, or very early in the spring, posts at least six feet long should be firmly and securely set, one at about eight feet from the end of each row and securely braced lengthwise of the rows, and good, strong galvanized wires should be tightly stretched, and nailed with fence staples, from one end of each row to the other. The first wire should be placed about fourteen inches from the surface of the ground, and at least three additional wires, fourteen inches apart, should also be securely fastened to the posts, as above stated, thereby forming a trellis to train the canes upon. Tie the canes to the lower wire, not too tightly, else when they grow the twine used will cut off the canes. Wool twine or some other kind of soft, strong twine is the best and most satisfactory for the purpose.

Cultivate thoroughly and frequently between the rows with a Planet Jr. horse hoe, about three inches deep, during the season, using a hand hoe around the vines and between each post of the trellis, to keep down all weeds and grass and form a soil mulch around the grape-vines. Should any fruit bunches form the first or second season after transplanting, pinch them off while young and tender, as if left to mature on the vines they will weaken their vitality to such an extent as to materially injure succeeding crops, and be of but little value to the grower. Clip off all laterals just above the first leaf as fast as fully formed, until the third year after transplanting. "Prune off all surplus wood (leaving only one strong bud in a place on each main cane) in the winter season, as above noted, and you may be reasonably sure of an excellent crop of choice grapes each year that you continue to do your whole duty by your vineyard. Thorough and clean cultivation and both winter and summer pruning should be persistently kept up in the vineyard; also spraying with Bordeaux mixture, in the early spring before the buds start, should be kept up during the entire life of the vineyard. 


\section{VINEYARDS.}

By GeORge Holsinger, Rosedale, Wyandotte county.

Of all the fruits with which I have had experience, I know of none more satisfactory in results or that will respond to the efforts of the horticulturist better than the grape. It is easily cared for, requires comparatively little cultivation, yields generously, is very popular as a table fruit, is easily picked and marketed, and has the supreme good quality of not requiring immediate marketing when ripe.

The cultivation of the grape requires an ordinary use of plow and hoe. Our $\nabla$ ineyards receive seven or eight plowings and two or three hoeings a season. The first plowing of the season is done with the eight-inch diamond plow, and the dirt is thrown to the grapes. This covers all the weeds, refuse or manure that may be on the surface, and leaves a narrow ridge in the row to be hoed. All subsequent plowings are done with the double-shovel, or five-toothed-cultivator, and as often as is necessary to keep down the weeds and the soil mellow.

Methods of pruning are many, and I suppose about equally good, each grape grower using his own preferred method. Our method is a combination of the upright and horizontal systems, and is intended to distribute the fruit and foliage so that the grapes will not burn for want of shade or become spotted and rot under too dense foliage. The trunk is not allowed to become more than a foot in length, and from this six or seven shoots are allowed to grow throughout the season, except in heavy soils, when summer pruning becomes necessary to prevent too dense shade. At the end of the season, when the trimming is done, the canes are reduced to four in number and are cut back to about four feet in length, leaving perhaps forty eyes. These are now spread out fan-shaped on the wires and tied securely to the top wire by willow withes. Willow is used because it is cheap and more quickly applied than pawpaw or string. One should be careful in tying to see that all vines are tied close to the lower wire, to prevent injuring from a long singletree in the hands of a careless driver. The lower wire is usually thirty-six inches from the ground and the upper one four to ten inches above that, so that the top wire should be at least forty-five inches from the ground. My reason for having a high lower wire is to keep the fruit high above any weed that may get a start in the rush of berry picking or in a wet season.

In planting, I would prefer a gentle slope to level upland or bottom, unless the upland be thin. Thin land, heavily manured, is better than heavy soil, and, in particular, the land should be thoroughly drained. We plant in rows, seven or eight feet apart, and the same distance between vines. This gives each plant plenty of room, and insures a passageway for wagons in collecting the picked fruit, as also for manuring. Suppose you desire to plant a vineyard eight feet each way, with rows running north and south. First, mark off your rows eight feet apart, east and west, with a marker; next, run a cotton string the entire length of the field north and south where the first row is to be located. This will give the exact location of every plant in the first row, the points being at the intersection of your string and row mark. Now make your hole in the shape of a triangle, with your acute angle at the intersection of your string and row mark. The point where the plant is to rest next the string should be shallow, and eight to twelve inches in depth at the base. This will give the plant a good setting, will prevent scratching by careless plowmen, with the additional advantage of giving perfectly straight rows, a point not to be overlooked in vineyard planting.

As to varieties for commercial purposes, the Concord should be classed above 
all others. Moore's Early is a splendid veariety, and would be second on my list. Being of better quality, it commands two and one-half to five cents more per ten-pound basket than does the Concord. Champion is good only because it is early, but it must be marketed as soon as colored, for it has no good qualities to recommend it, and when Moore's begin to go on the market there is no sale for it. In addition, I might say that as soon as it is ripe it shrivels. Grapes for local marketing are still sold in pick-split baskets, but there is a tendency to adopt the eight-pound hard basket, because it can be shipped without repacking, is more easily handled, and, in addition, it is about the size demanded for family use. The result of this year's grape crop was very satisfactory in the eastern portion of the state. We had a good crop, with good prices. Concord, Moore's, Worden, and Elvira, besides many other varieties, had a splendid showing of fruit. Champion was remarkably full; the second big crop we have ever had of them. Woodruff, though only one year planted, had fruit sufficiently plentiful to warrant planting more extensively. We had no grape rot in our immediate neighborhood, although the crop in vineyards at a distance of two miles was almost entirely destroyed. Good, compact bunches, and plenty of them, were more in evidence than for at least three years previous. As to the planting of fancy table grapes, it will not pay unless the grower can do his own marketing. A few fancy grapes can be sold for good prices, but the old standbys are still the money-makers.

\section{REPORT OF GRAPE GROWING IN 1900.}

Read before the Kansas State Horticultural Society, December 29, 1900, by A. H. BuCKMAN, of Topeka.

The grape crop of 1900 in Shawnee county was medium. Prices in Topeka, for seven- and eight-pound baskets, ran from nine to eighteen cents, commission taken out; commission men handle most of ours, saving time and trouble. We realized two cents per pound for the whole crop. Grapes had peaches to contend. with this year. The three black varieties, Moore's Early, Worden, and Concord, rule the market, although we had no trouble in selling Green Mountain and Delaware at double prices, or half-size baskets at same price. Woodruff Red and Moore's Diamond are good sellers, and will always find a market, grown in any quantity. The present season has been no exception to the worst enemy the grape grower has, and that is the man who pulls his grapes green, or as soon as colored, and forces them upon the market before they are at their best. The crop of 1900 ripened from six to eight days earlier than in 1899.

Bush says miscalled rose-bug is a leaf-eater. This year it was more numerous. This is the third year it has troubled us. It commences its work the last. of May and is gone by the last of July. A small vineyard near the house, where the poultry runs, is apparently clear of this pest. Out of fifty or more kinds we have experimented with or tested, Green Mountain, Moore's Early, Worden, Moore's Diamond, Concord and Woodruff Red have paid the best, and, for late home use, Goethe.

We are more impressed than ever in favor of a black, deep, rich soil, with clay subsoil, for grapes, where the land is so near level that the water will run off without washing. This kind of land holds the foliage, and seems to resist diseases of vine and roots better than loose, sloping land. Our oldest vines, thirteen years planted, have been the most profitable this year. We have been disappointed in Campbell's Early and McPike; Campbell's Early cannot compete with Moore's Early, and McPike is an inferior Concord in size and quality. 


\section{GRAPE REPORT.}

Read before the Kansas State Horticultural Society, December 29, 1900, by M. E. ChANDLER, of Argentine.

The grape crop the past season was the largest we ever handled. Prices ranged from ten to twelve cents per eight-pound basket for Concord and Worden; fifteen to twenty cents for Moore's Early.

Some vineyards on high prairie land were badly affected with black rot; some losing the entire crop, while on our sandy clay the rot was less than ten per cent.

Spraying would have been almost useless this season, owing to the excessive amount of rain washing it off; but when the seasons are favorable, spraying with Bordeaux mixture (six pounds copper sulphate, four pounds lime, to fifty gallons of water) will check the black rot.

We found the Knapsack sprayer as quick and as handy as any to use in the vineyard.

The vines made an excellent growth this summer and are in fine condition for next year.

Grapes should be sacked for home use, to be used after the main crop is gone, but it will not pay for market, at the low prices of the past few years.

Tender varieties have almost recovered from the cold winter of 1898-'99. As commercial grapes, I would recommend Moore's Early, Worden, and Concord; a few vines of Champion may be planted for extra early; for red and pink table grapes, Moyer, Delaware, Lindley, and Goethe; for white, Niagara, Moore's Diamond, and Green Mountain.

Vineyards should be trimmed in the fall, posts reset, and not left until spring, when the ground is cold and wet. Do as much work in the fall as possible and you will not get behind with work in the spring.

We have not tested the new grapes, McPike, Green Mountain, Campbell's Early, and Hicks, enough to know what they will do.

\section{VINEYARDS, 1900.}

Read before the Kansas State Horticultural Society, December 29, 1900, by A. L. Entsminger, of Silver Lake, Shawnee county.

The fall and winter of 1899-1900 was very favorable for a good crop; the following spring was also favorable for the blossoming and pollenizing of the fruit; consequently a large yield was the result; many shoots of new wood having three and sometimes four or five bunches flourished and did well until about two-thirds grown, when in some vineyards not well cared for rot was very noticeable, and in some localities the crop was almost, if not quite, destroyed; some vineyards escaped until nearly ripe and then dropped badly. However, care and attention, with thorough cultivation, act largely as a preventive. We believe the later rotting of the fruit is different from the early or bird's-eye rot, and will prove much more destructive, as the sprayer cannot be used when the fruit is so nearly mature. As for my own vineyard, there was little reason for complaint, as there was no damage to the vine or fruit, excepting a very little rot and some dropped late in the season, caused by a fungus attacking the stem, which was so slight that we did not consider the loss anything. The older varieties which suffered the most were the later ones, such as Elvira, Columbian, and Concord. I grow many varieties, but would only recommend for profit those well tested, as nearly all of the new varieties fall far short of the introducers' claims. The much-praised Campbell's Early is so tender as to be practically worthless in this latitude. 
Chandler's Seedling (a Kansas variety) did finely. It is like Pocklington, but much larger and of better flavor, and very late; Clarissa, white, promising, fruited in a small way; Mallyey, tender, like Agawam in all respects; Amelia, black, a little tender, very fine flavored, have fruited it twice; Chicago, have fruited it twice, much like Delaware, good grower; Tennison, white, too tender. The above five varieties were received from Michigan for testing. Some of them are very promising. Bonnie Doon is a perfect Brighton, ripening in October, have fruited it twice, very promising, a little tender; Souvenir, white, has not done well; Genevra, fruited twice, very fine, very large, white, good, and very compact in bunch, ripe in October, fine flavor, hardy as Concord, and a good grower. I think it safe to recommend this variety. The three above-mentioned varieties are undisseminated; I received them from Michigan on restriction. Chidester's Seedling, has fruited one vine three seasons, berry and fruit about the size but two weeks later than Concord, about the color of Catawba. This promises to be an all-round, first-class grape, and if it is as satisfactory hereafter as it has been thus far, I will not fear to recommend it in this latitude.

Of the very recent introductions that we are testing are: McPike, a very poor grower, have had it two seasons, and, with all the care and attention that we could bestow upon it, we could not make it reach the trellis; the Hicks, have had it two years, has made a very fine growth; I got it onto the trellis the first season, and last season it bore a bunch of three grapes; the St. Louis is another very fine grower, have had it two seasons, not fruited yet. The two last named are the production of Henry Wallis, Wellston, Mo.

The yield of grapes varied much, the highest being about four tons per acre. Prices were very good, ten cents per basket being the lowest; yet first-class, wellpacked grapes did not go below twelve cents per eight-pound basket. Moore's Early brought the best price, closely followed by Worden, Concord, and Telegraph.

Vineyards are now in very fine condition; perhaps never more promising at this season of the year.

\section{DISCUSSION.}

The following is a part of the discussion on grapes by members, at the thirtyfourth annual meeting of the Kansas State Horticultural Society:

Senator Taylor, Wyandotte county: I notice that some one claims that people rush their grapes onto the market before they are ripe. I do not see how that is detrimental. Now, people in town know as well as those in the country that such grapes are not ripe. The Champion is taken to market as soon as it colors, and they are not fit to eat. I cannot see why grapes placed on the market before they are ripe should have any effect on the general market.

J. L. Williams, Wyandotte county: I market grapes when half ripe and still sour; there are many people who desire grapes when they first come to market, even if not yet ripe. Half-ripe grapes are all right for cooking. Considering the use to which unripe grapes are put, I do not see how the market is injured by their being sold.

G. F. Espenlaub, Wyandotte county: I know that the grapes growing on the southeast slope are the grapes for money.

W. G. Gano, Missouri: There is much dissatisfaction with the Worden. I know of a good many Wordens being plowed up within the last few years. It is much like the Delaware and I think it is as good. It is the best grape to raise except the Delaware. 
J. L. Williams: Mr. Gano made an assertion about the Worden which is not carried out in our part of the state around Kansas City where they are properly cultivated. I trimmed 500 Worden vines last year and they had a good crop of grapes on them this summer, and there was never a finer crop of grapes raised.

A. Chandeer, Wyandotte county: That shows that they were not Wordens.

J. L. Williams: I am sure that they were Wordens.

George Holsinger, Wyandotte county: At the Chillicothe meeting it was asked if anybody had had any experience with the Hicks. I got up and said they froze, to the ground. Mr. Wallis (the disseminator) came down to my home place for the purpose of killing a man about my size, but he found that others had the same experience.

F. W. Dixon, Jackson county: I have a Hicks vine. It did not kill to the ground, but it was in a protected place. It was planted a year ago last spring, and this year it had one lonely bunch of four grapes. I would not like to say anything for or against it. I hope it may bear more grapes next year.

Secretary Barnes: Among the correspondents of this office, C. C. Cook, of Bradford, Wabaunsee county, wrote me that in the spring of 1899 he planted one McPike grape-vine; that in the spring of 1900 he trimmed it to one arm, and from it broke forth fourteen shoots, and on July 28 (when he wrote) it was carrying forty fine bunches of fruit.

A. Chandler: Has any one tried the dust method of spraying grapes for rot, and what have the results been?

EDwin TAYLoR: Can you not answer your own question? Do you know any one who has tried it?

A. Chandler: Not to any extent. I would like to inquire the chemical nature of the mixture of lime and Paris green used; whether they combine or keep intact?

Mr. Banks: I cannot say much about it only on a small scale. We have a dust pump used for small fruits. I cannot say how it would work on a larger scale. It can be turned very easily and rapidly and throws fine dust with great force; I think a larger one would work as well.

EDWIN TAYLOR: Did it do your fruit any good?

Mr. BANKs: It kills the fungus. I do not know that it will kill insects unless you use insect-powder. It is good for mildew.

Edwin Taylor: Did you ever use a liquid spray?

Mr. Banks: I never used a liquid spray in the greenhouse.

A. Chandler: We have a chemical change and a new compound forms as soon as water is applied; but I do not think that [dry] lime would act on the dry poisons that are put with it. Dust is so much easier than liquid to apply; yet the poison must be in solution before it can kill, and perhaps the dust that lights on the leaves is combined with the dew that falls during the night.

Chas. Harrington: In our county"(Labette) we tried the dust spray. I think that the best sprayer is the Automatic, which allows you the free use of both hands. They are made by several companies.

Mr. Chandlre: Dust spray can be used wherever liquid can. When the wind is right for liquid spray it is right for dust spray. In this solution you mix your Bordeaux and add the lime. Prepare the Bordeaux mixture just as you would for liquid spray. Then add the lime and use it, and I am certain from what I have seen that you can use dust whenever liquid can be used. I am anxious to know if it will be a success; perhaps it has not been sufficiently tried.

G. W. Maffet : Do you mean air-slaked lime? 
Mr. Marshall: You can make the solution of copper sulphate; dry-slake your lime.

Edwin TAYlor: You must use more lime than is ordinarily used with the Bordeaux mixture.

Mr. Marshall: You use about two pounds of copper sulphate to a bushel of lime. All the lime is for is to carry your Bordeaux. It will take perhaps a barrel of water to slake a bushel of lime. I suppose a gallon of water would perhaps take up two pounds of sulphate in solution. The water only takes up a small amount of lime in proportion to water used. I happen to have one of those dust sprayers that Mr. Chandler is talking about. I cannot recall the name of it. The instructions that came with it were, to make a solution of copper sulphate, then add lime, and then let it complete the slaking in the air if necessary. I could not see how to keep up the relative proportions of sulphate of copper. I was not familiar enough with the action of the lime and copper to know just what proportion it would take to destroy. The dust is death to you as well as to the insects, and a man to use it ought to have neither eyes, nose, or mouth. I had some web-worms, and I thought I would try this dust on them. I went out with this mixture, but, in order to throw it up into the trees, the wind will have to be blowing pretty strong.

Major Holsinger: The inhalation of this mixture can be avoided by placing a wet sponge over the nostrils. This prevents the unhealthful part of it.

\section{PRACTICAL METHODS IN GROWING GRAPES.}

Experience has taught me that labor expended in preparation of the soil before planting pays best; therefore I would grow some hoed crop upon the soil before planting trees or vines, unless I had a clover sod to use for the purpose, which furnishes the best foundation for plant growth, the roots of the plant loosening and aerating the soil, and storing up the very elements needed.

In our section we plant vines in rows nine feet apart, and ten feet apart in the row for free-growing kinds, such as the Concord, Worden, Moore's Early, and Niagara. Varieties like the Delaware and Green Mountain can be planted eight by eight. Care should be taken to secure vigorous, well-grown vines, preferably two years old, clean and free from mildew or fungus. Mark the ground ten feet apart the opposite way from what you want the rows to run, then with a twohorse plow mark the rows for planting nine feet apart, going twice in a row and plowing as deep as you can (presuming that the land has been deeply and thoroughly plowed previously), so that in setting the vine it can have some loose soil under it; and I want to set the vine at least six inches deep, so that the aftercultivation will not disturb the roots, and a dirt mulch of three or four inches can be kept over the roots to conserve the moisture.

Before planting the vine trim off all superfluous wood, and leave only three or four buds to grow. As some hoed crop is supposed to be raised the first year (but never a sowed crop), it is well to stake the vines, to prevent injury, and if vigorous growth is made it can be tied to the stake. The vine is now left until winter, usually February, when the strongest cane is tied to the stake, all side shoots cut off, and top shortened to five and a half or six feet. All other canes are cut close to the vines, and all shoots that start from them broken off. If any fruit should set the second year it is best to remove it, and let the strength of the vine go to production of wood. In the fall of the second season, or the spring of the third season, we set the posts in the rows, leaving two vines between posts. 
Brace the end posts, and put two wires on them; one three feet from the ground, and the other five and a half or six feet. We use No. 11 wire.

Third year: Now trim your vine, if it has grown enough so that you can do it, leaving one arm on each side of the head of the vine. Cut these arms back six buds to each and tie to the wires. Train the shoots along the wires, and tie. Let but few - not over ten-clusters of fruit remain on the vine.

Fourth year: Select the best cane nearest the head of the vine for your bearing cane. Cut off all wood beyond it. Trim these bearing canes and cut off the ends, leaving ten buds.

Fifth year: Select the best cane near the head of the vine for your bearing cane the coming season, and leave twelve buds on each bearing cane. Cut off all wood beyond these bearing canes. Tie these long, bearing canes to the upper wire. If there is not sufficient room for future growth, carry alternate canes down to the lower wires and tie in umbrella form.

After the fruit is set these vines should receive their summer pruning, which consists of removing the tendrils or clingers, and cutting off the ends of the bearing canes at third or fourth leaf beyond the fruit, excepting only the cane nearest the head of the vine, which is not shortened, but left to grow for the bearing cane for the following year.-Strawberry Culturist.

\section{CARE OF GRAPE-VINES.}

The grape-vine should not be planted more than six or eight inches deep, as the feeding roots are found very near the surface. If the vine is long, plant in a slanting position. When the vine is first set, cut back to three buds. The object of leaving three buds is to be sure of one to grow; if they all start, rub off all but one, and, as that grows during the summer, tie to a small stake. By giving the one shoot the whole growth that the three would make, at the end of the season a nice cane will be produced, and the process is as simple as growing a hill of corn; cut this cane back to three or four buds. The following season train up two shoots in the same manner. Subsequent pruning will depend on how the vine is to be trained; also on its habits of growth. But avoid allowing too much wood to grow; this is always at the expense of fruit, whether of tree or vine. Do n't bury them alive - they can't grow out and will surely die. Pick up those old bones, boots and shoes - all the chickens that die - and plant near the grapes; and the prunings of the vines are good. Do n't burn any old boots - they are worth fifty cents each to grape-vines.-Geo. J. Spear, Greeley, Colo.

\section{MAKING A VINEYARD.}

T. V. Munson, the great authority on grape culture, of Denison, Tex., has written for the Texas Farm and Ranch a paper on "How to Start a Vineyard, which explains, among other things, Mr. Munson's system of trellising, which differs from that used by most growers. Mr. Munson claims his plan is better than any in common use. His paper follows, omitting reference to varieties, some of which recommended do not grow well in this latitude.

The site and soil have much to do with making a vineyard profitable or unprofitable; hence too great care cannot be used in selecting a location.

The ideal site has an eastern or southeastern exposure, with sufficient slope to secure surface-drainage, but not enough to wash badly in the heavy rains. 
The ideal soil is a reddish, sandy loam, with a reddish clay subsoil, porous enough and deep enough to absorb the heaviest rains without becoming boggy or seepy. Such soils and locations are less invaded by the mildews and rots so disastrous to vineyards in low, damp, heavy lands, and are far less subject to killing by late frosts.

But no one need be without good table and market grapes, even if his soil is heavy and damp; for a little drainage, subsoiling and fertilizing will largely correct what nature has failed to do.

Next to the red and chocolate sandy soils come the black, sandy soils on red or yellow clay. 'The poorest are the low, blue, livery soils, that are seepy in wet and hard as a bone in dry weather. But the black, waxy and adobe soils, in good sites, planted to some varieties, give good results.

Having chosen the site, the soil should be thoroughly prepared. Failure to do this will cause many sad crops of disappointment to be gathered.

The land, if beset with stumps and rocks, should have them all dug out to a depth below where the plow will reach. When the land is free to be worked at your will by the plow in all its parts to at least two feet in depth, lay off the rows-preferably running from northeast to southwest, if the land will permit; then plow in narrow lands the width that the rows are to be apart. I have found nine feet from row to row the most desirable width, so a wagon can be driven between. Begin plowing each land midway between where the rows are to stand, and backfurrow to this center, following the first plow with another, preferably a subsoil plow, as deeply as a heavy team can draw it, remembering that never, after the vines have once filled the soil with their roots, can deep plowing be done in the vineyard during its life without great damage. In finishing each land, go an extra round or two in the dead furrow, throwing out as deeply as possible, not less than two feet-three will be better. Then let the land lie awhile to receive ameliorating influences of weather.

If the land is at all heavy or seepy or poor, the dead furrow should have placed along its bottom, three or four inches in depth, poles and brush, lying close down lengthwise, with crushed bones and leaf-mold from the woods intermingled. When ready to plant, begin at the dead furrow with a broad, heavy turning-plow, and turn the land back over the poles, bones, etc., until the soil is two feet deep over the poles, and the final dead furrow, which need not be opened very deep, is midway between where the rows are to be set. A cross-section of the lands thus prepared would present something of the appearance of the illustration shown herewith.

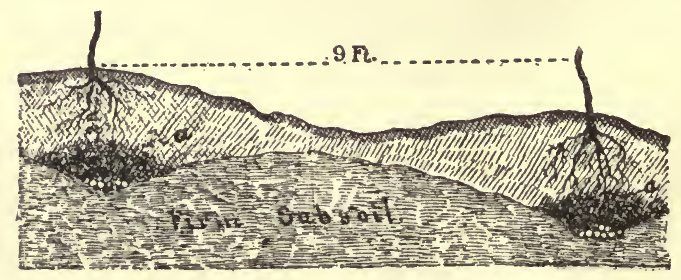

$a, a$, Brush, bones, leaf-mold, etc.

A vineyard planted on land thus prepared, and of varieties adapted to the climate, should, with proper care, live 50 to 100 years under profitable bearing.

SETTING THE VINES.

Strong, healthy one- or two-year-old plants-never older, unless to save rare varieties - should be used. 
Cut the roots back to six or eight inches with sharp knife or shears, and tops to three buds. Have all the plants thus prepared, and tied in bundles of as many as there will be vines in a row, if the vineyard is to be of considerable size; each variety correctly labeled and separate. Have the vines thus prepared heeled in moist soil where they are to be planted, and arranged in order in which they are to be set.

With a turning-plow, let a careful man, going by stakes set in straight lines at right angles across the rows as already prepared, lay off straight furrows four feet apart.

After the vineyard ground is thus "laid off" one way, set the stakes in a straight row, directly over the line of buried poles, or the deep dead furrow first made, which is now under where each row is to stand, and lay off the furrow well and deep. If all has been properly done, these furrows will be nine feet apart.

Let one person take the vines of the first variety, and if such be Delaware, Moore's Early, Ives, Concord, or other varieties of moderate growth, place a vine properly in every other cross-furrow, thus putting them eight feet apart along the row, while another person attends him with a spade and covers the roots carefully with mellow, fine soil, finally pressing it down firmly with the foot all around, leaving the two buds just above the surface of the soil. If the variety is Herbemont Le Noir, or hybrids of these, or post oak grape hybrids, set a vine in every third cross-furrow, thus giving each twelve feet distance to other vines in the row. If the land is very strong, these varieties will do better sixteen feet apart-one in every fourth cross-furrow - and will fill the entire space of trellis well with fruit, and fare much better than if set closer and pruned shorter.

Scuppernong, Thomas and others of the Muscadine varieties should never have less than sixteen feet of space.

If any varieties have imperfect flowers, such as Brighton and some others, plant next row to them in kinds with perfect flowers that bloom at the same time.

After the vines are all thus carefully set, make a record of the plantation in a book for the purpose and preserve for future reference. It will save much confusion and be a great satisfaction in comparing varieties.

Varieties of grapes are less known and understood generally among nurserymen than are varieties of almost any other class of fruits; hence you should be especially careful to secure vines from thoroughly posted and reliable growers.

TRELLISING, PRUNING AND TRAINING THE VINE.

After trying for years the various forms of grape trellises in common use, and studying the natural demands of the vine, and its behavior on the various trellises under different methods of pruning and training, I became thoroughly convinced that none of the trellises recommended in works on culture of the grape were fully adapted to best training of the vine, as it grows in all regions where irrigation is not in use, the air moist, growth of vine great, and some form of trellis support absolutely necessary to enable the vine to bear marketable crops. The Kniffin system of training had most merit, but was imperfect, especially for a windy country.

The vine in nature invariably tries to make a canopy of its foliage over its fruit, body, and root, and yet above ground sufficiently to allow ventilation and diffused light enough to favor the proper development and ripening of the fruit. This was the key to my invention.

With the single post, the winds thrashed and twisted the vines about until the ties were worn off, and down they came, full of fruit, to the ground, the crop greatly damaged, and requiring immediate attention in tying up again in the 
very busiest season. Besides, there was never room for the vine to properly expand itself. The lower part of the body was exposed to the baking sun, and in a few years killed along its southwest side. The foliage either matted up in a bundle, choking the fruit, or had to be kept cut back too closely for the health of the vine. The crops were small and uneven in quality, and the vine shortlived. Besides, the post in the center was a perpetual harbor for insects and fungi, ready to prey on the vine and fruit.

In the vertical three- or two-wire trellis was found a large improvement, especially with the Kniffin method of long-arm pruning and drooping training. The fan training on such trellises was next best, and the Fuller system poorest, because so tedious in detail and the incessant pinching necessary to maintain the balance of the vine. All, however, lacked the proper canopy of shade, permitted uneven exposure of foliage and fruit to wind and light, presented a broad surface of resistance to storms, and when the ground became saturated and soft, or the trellis a little old, whole rows would go down with a crush of fruit in a heavy blow.

Besides, the vertical wire trellises in a vineyard allow no free ventilation when full of foliage and fruit, and are the same as so many fences to oppose one's passing from row to row at any point in the vineyard.

So I might show the defects of all the other trellises commonly used.

At first I tried a two-wire canopy trellis, and have used it extensively for thirteen years, with much satisfaction. It has two parallel wires at the same height - five feet from the ground-and two feet apart, resting on the ends of arms bolted to posts, or on the ends of small posts set flaringly in the same hole in in pairs, thus:

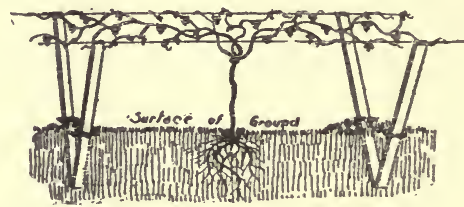

The Munson two-wire canopy trellis.

The defects of this are that the bearing arms, being tied along the wire, with no support above for the bearing shoots to cling to or recline on, are very easily blown off by gusty winds when tender, before the wood becomes hard and tough; the plow animal passing along in cultivating rubs off some shoots with the hames, and sometimes, when the fruit gets heavy, it carries the shoots down, reversing the foliage and fruit, when, if the sun is very hot, some fruit will scorch before the leaves erect themselves over it.

To overcome these defects, a third wire is run midway between the other two, and about six inches lower, making a broad V-shaped trough of the three wires. The bearing arms, after pruning, are tied solely to the middle, lower wire, as shown in the drawing of the three-wire trellis accompanying this article. This form of trellis I am also using, and find it as near perfection as I ever expect to get.

The posts and cross-bars, of course, should be of most durable wood. By having sawn posts of cypress, or bois-d'arc, or cedar, or black locust, or mesquite, or white post-oak, or burr-oak, and keeping them painted, they will be very durable, and give a tidy, thrifty appearance to the vineyard. The drawing shows the end post set deeper than intervening posts, and well anchored by buried rocks, or low posts may be used in place of the rocks. 
On the canopy trellis, all the summer pruning required is to go through the vineyard at or a few days before blooming time, and with a light, sharp butcherknife clip off the tips of all advanced shoots to be left for bearing, leaving two or three leaves beyond the outer flower cluster. From the shoots near the crotch, selected for bearing arms the next year, pick the flower clusters, and strip off or rub off all shoots and buds that start on trunk of vine below crotch. This latter is very important, as such shoots, if left, eat up the nourishment of the land, with no return but added work at pruning time.

It will be found that the shoots at the ends of the arms usually start first and strongest, and if not clipped back, will not allow the buds back toward the crotch to start well; but if clipped, all other desirable buds then push.

In about six to ten days after first clipping, a second one is usually necessary, especially if the weather is moist and warm and the land rich. The first clipped shoots, as well as the new ones, will need clipping back this time, the end buds on the first clipped having pushed vigorously.

SOME ADVANTAGES OF THE MUNSON TRELLIS.

See illustration on page 102.

1. It accommodates the nature of the vine, by furnishing a leafy, wellventilated canopy over fruit, vine, and root, and allows the fruit to hang in free air, so no chafing occurs against wires, or post, or vine.

2. It puts the work of pruning, tying, spraying and harvesting in the most convenient position possible to save backache and do the work most expeditiously, with the least inconvenience, and permits passing from row to row through the vineyard, at any point, by slightly stooping.

3. It allows more readily of cultivation than any other continuous trellis.

4. It permits free circulation of air and wind-storms, thus keeping the ground better aerated in wet weather, helping to restrain diseases, and avoiding blowing down of trellis; hence enabling it to last longer. The sheet of leafy vine, being held horizontally and edgewise to the winds, gives little resistance, and furnishes even exposure of the fruit to light, heat, and air; hence secures even ripening.

5. In cold climates, where vines have to be covered in winter, it permits the vine, as soon as pruned, to be readily laid down to be covered, and easily raised to be tied up in spring.

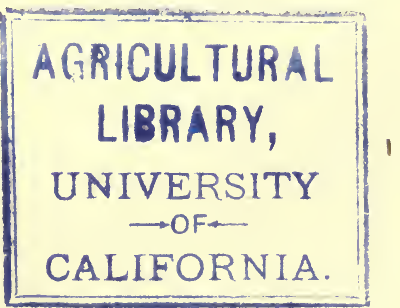




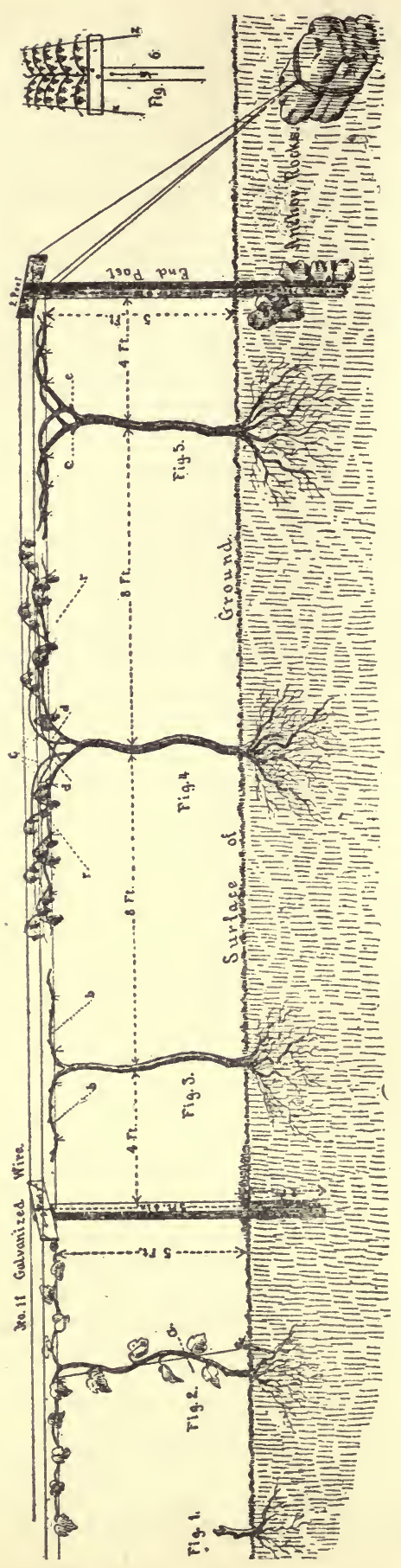

1 क्ञ

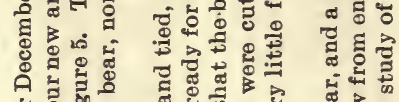

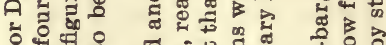

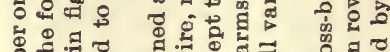
हैं क

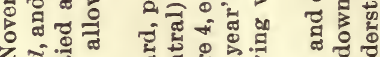

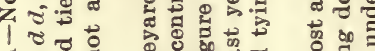
ङ

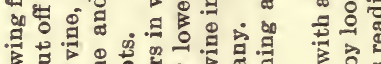

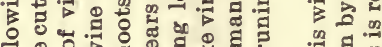

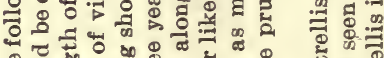
‡

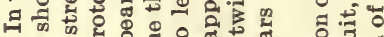

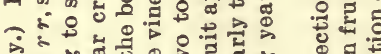
के ๑ o

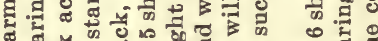

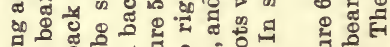

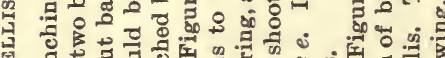

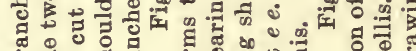

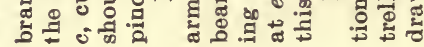
盟

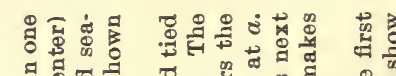

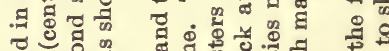
.

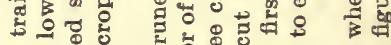

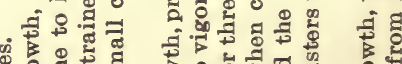
की के

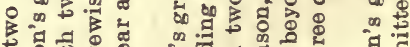

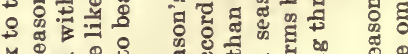

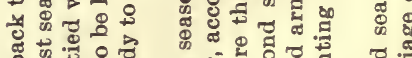

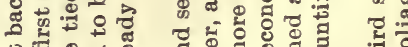

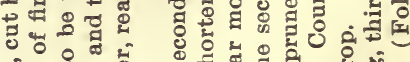

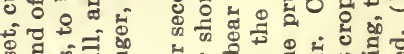

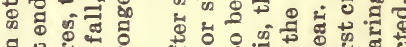

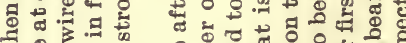
B.

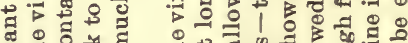

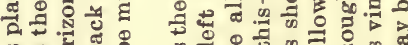
on के $\rightarrow$ क क 운 웅 + 연:

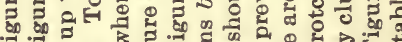

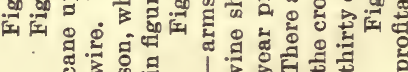




\section{THE VINEYARD-FROM THE PLANTING TO THE TRELLIS.}

In planting grape-vines, the variety governs the distance apart. I will speak of the Worden and Concord, two of the best well-known black grapes. I plant them in rows eight feet apart, and twelve feet apart in the rows.

The preparation of the soil should be deep and thorough. Set the rooted vines down to the last bud. Prune them back to about four buds on the canes made while they were being rooted. If the soil is rich, and a rank growth of vine is expected the first year, let only two canes grow; if soil is poor and a feeble growth is expected, let only one cane grow.

Supply each vine with a stake seven feet tall. As soon as the vine starts climbing tie it to the stake, rubbing off all side shoots or laterals; tie up and prune after. Keep the vine climbing straight up the pole and allow no growth wasted in surplus laterals.

Cultivation should commence early and be thorough. A single section of a fifty-tooth, steel-frame harrow, using one horse, is a very convenient and suitable outfit with which to keep the surface in good condition and surplus vegetation in check. Some hoeing may have to be done to destroy such strong-rooted weeds as the harrow will not tear up. Some weeding in the hill also will be necessary. About the middle of June, if you like, plant the ground to cow-peas, the Whippoorwill being my favorite, on account of its bunchy habit of growth. Keep the harrow going just the same, at least once a week through the rows both ways. There is a short period of time, all pea growers know, that it will not do to harrow them, and this is from the time they first come up until the third leaf appears. When the vines get too rank for the harrow it is time to stop cultivation. When the peas ripen they can be hand-picked and saved for seed. The vinescan be left on the ground and serve a splendid purpose as mulch to prevent the winter rains from robbing the surface soil of the fertility brought there by the peas and the thorough cultivation. The grape-vines can go into winter just as they are. I had rather prune as Eoon in the early part of winter as practicable; say as soon as the wood is fully ripe. This pruning is simply cutting the canes back to within two feet of the ground.

The Second Season.-Whether a trellis should be put up now or let the vines run on the stakes, depends on the richness of the soil and the growth the vines are likely to make. Be that as it may, they will only yield about ten to thirty bunches of grapes near the ground. If left on the stakes, cultivation can be more thorough, as we can go both ways again. I favor the stake plan for this year, letting from four to six canes grow, pruning and tying up as before. Rag strings will serve for tying; they are soft and do not cut the canes. The curl of the vines will soon catch and help support them. I have Concord vines now at this stage, the year's growth measuring twenty feet. Think of what a wire trellis they will cover; twelve feet apart is none too far. I will use three No. 11 smooth wires, the top one eight feet from the ground, the bottom one two feet. This leaves me seventy-two square feet of trellis for each vine, besides the twenty-four inches below the first wire, which is often used by the vines that yield grapes. A vine like this will produce the third year from twenty-five to fifty pounds of grapes, at five cents per pound. In the former estimate my 300 vines would yield me $\$ 375$, and in the latter $\$ 750$. The land they occupy is much less than an acre.-E. W. Geer, Farmington, Mo. 


\section{THE GRAPE.}

A paper read by SAMdel Miller before the Missouri State Horticultural Society.

The grape was grown before the deluge. Whether Noah took rooted vines or cuttings with him when he entered the ark does not matter; but the first thing he planted when he came out of it was a vineyard. This certainly gives the grape a prominent character among the productions of the earth. That it is one of the best and most wholesome fruits is also admitted. When Noah's vines bore fruit, he made wine and got drunk; this is only what countless thousands have done since then and will most likely continue to do to the end of time.

From that vineyard of sacred history to the present time the grape has held a prominent place among the best fruits of the world. Its range of latitude is almost as great as that of any other fruit except the strawberry. It grows in swamps and on high mountains, in a great variety of soils; yielding many varieties, from the little, insignificant summer grapes of our Missouri islands and bottoms to the magnificent Muscats, Hamburgs, Moroccos, and Syrians. The latter has grown bunches that weighed twenty-eight pounds. A traveler once stated that he came across grapes in Afghanistan with bunches half a yard in length, and with berries as large as small walnuts.

In the early part of this century the grape received, in this country, but little attention, and the attempts to grow the viniferas were failures. The fox grape (labrusca), in the East, and the chicken or fort grape were about the only ones that survived, and even these, to my personal knowledge, failed some years from rot and mildew. Some years the first named all rotted, and the latter I have seen when the bunches looked as if they had been made wet and then rolled in flour, they were so white with mildew.

Now where are we? Here in the West we can grow good grapes, and we have boasted about it in times past, notwithstanding there are car-loads imported into our state yearly from Ohio and New York. This should not be so, as we can grow our own grapes. Of course the early ones are soon gone; but we have late ones, such as Goethe, Woodruff Red, Norton, Cynthiana, Kentucky, Ozark, and Hermann, that can be kept late if properly cared for.

There is no occasion for me to dwell on the subject of cultivation in this paper, for every journal gives instructions in this line; or on propagation of vines, as this topic is also freely discussed. That some varieties grow readily from cuttings, while others cannot be grown successfully in that way, each one will learn by experience. Varieties differ in their habits and no definite rule can be laid down for all varieties.

Of the newer varieties introduced within the last few years, I will mention Campbell's Early, of Concord parentage; bunch and berry large, black; quality superior to Concord and ten days earlier. This should be in every collection and can now be bought for fifty cents a strong vine. I paid $\$ 2.50$ when getting my first vine. Then we have the McPike, a most noble grape, a seedling of the Worden: just like it, but much more so-larger and better. Hicks, a grape brought out by Henry Wallis, of western St. Louis county, Missouri. This grape is destined to make its mark. The bunch and berry are above the medium, black; quality as a table grape the best. . . . The Kentucky is another of recent introduction, of the Norton type, but larger in bunch and berry; a pleasant table grape. . . . Just here let me say that the Norton and Cynthiana are considered by most folks as only wine grapes, but I deem them excellent for eating, and prefer the latter, when it is ripe, to the Concord.

Among the older varieties, I would name the following for a small collection 
for the amateur: For white-Green Mountain, Moore's Diamond, and Pocklington; red-Brighton, Catawba, Woodruff Red, Goethe; black-Early Victor, Worden, Defiance, and Norton.

If people only knew it, and would carry out their knowledge in a practical way, every man owning a house could have grapes enough to eat and not occupy land availiable for ordinary plants. Plant against the walls of the house and train up under the eaves, and there will be neither rot nor mildew to injure them.

The danger from swallowing grape seed is greatly exaggerated, in my opinion; but at the same time a grape fit to eat should have the seeds rejected. It is true that some varieties are sweet between the skin and pulp; the latter is often swallowed whole, for if bursted it will be somewhat acid inside; but that is not my way of eating grapes.

I pity the man who has the land and no grapes; yet at the same time I will say that he is neglecting a duty that he owes to himself, his family, and the public in general.

In concluding this paper, I must not forget to give an account of the latest great acquisition. It is an ever-bearing grape; one that has on the vine, at the same time, ripe fruit, green fruit, grapes no larger than bird-shot, and blossoms. There is ripe fruit from July until frost, which they did not get at Belton, Tex., this season until November. The bunches are large, sometimes weighing three pounds; berry large and the quality No. 1. I have had two opportunities to taste this grape and see it in the different stages of development; therefore write from experience. I have a vine of it that has made twenty feet of wood this season. This may indicate what this vine will do here next season. It is of the vinifera class, and will have to be protected in winter. J. R. Allen, of Texas, is the originator of this new grape. To save trouble, I will state that I have no vines or wood of it for sale.

\section{GRAPE CULTURE.}

Mr. W. Mead, of western Virginia, is a practical, all-round fruit-grower, and has the following advice to give in regard to grape culture for Green's Fruit. Grower :

I apply manure to the soil for three years after planting, and yet on some soils this might not be necessary. My object is to give health and vigorous growth to the vines and to get the trellis covered as soon as possible. After this my attention is given to the canes and body of the vine. In future years, after the vineyard has borne several crops, I manure it every other year. After three years' growth I prune back to two buds. When the vine is seven or eight years old I cut back to one bud. My practice is to have as little of the old bark left on the main cane as possible, as it makes a place for insects to hide. If you want fine, large clusters, prune your vines back closely and do not let the canes run over seven or eight feet. Thin out the arms during the summer. Do not allow the clusters to form too thickly. Clip out where the clusters are too close, when the grapes are about the size of shot. Do not remove the leaves from the vine, as some people recommend.

Grape-vines are desirable and attractive for covering sides of buildings, barns, or walls, and you need not be afraid that the vines will do the building or walls any harm. They will protect them. Plant grape-vines for the health of your family, and for their enjoyment.

The longer you permit your canes of the grape-vine to run the smaller the fruit will grow.

The greatest percentage of sugar is formed closer to the roots of the grapes, and not at the extremities. 


\section{TENDING TO GRAPE-VINES.}

Very few vines give better satisfaction than the grapes, says S. W. Chambers, in the American Cultivator. Cultivating them on a large commercial scale has been reduced to a science that takes away a good deal of the sentiment which attached to the old family grape. Grapes are so cheap now that many farmers are giving up growing them for home use, depending upon the markets for all their families consume. For a fruit that is so easily raised this is a mistake. Enough grapes should be raised on trellises or arbors to provide eating for the whole family from early fall to the middle of winter. There should be an abundance on the table all the time, for there is no healthier fruit raised, and plenty should be left over for canning.

The mistake is often made on farms to let old out-of-date vines clamber over the arbor. These should be torn down and some of the best varieties planted. Select one variety each of the early, medium and late grapes. Then let them grow in a thrifty condition, stirring and enriching the soil and about their roots when they need it, and pruning them back every fall. About all the care grapes raised for home consumption need in this way is to loosen the soil occasionally and prune them back. More depends upon the pruning than most growers imagine. This has more to do with the bearing of the vine than anything else. Very often it is better to prune them back to the main stem, leaving only one joint on each branch. Then let this joint produce one branch that can be trained to the trees. By repeating this operation the arbor can be covered with branches and stems that have been carefully selected with a view to their special fitness. There will be no abundant vine growth then, and every branch will produce its quota of grapes.

Grapes to ripen well must have air. In the first place the arbor should be so located that the air can circulate evenly through it. If put away in some corner where no wind can blow through the vines, the fruit will not ripen well and molds and fungi will be more apt to attack them.

\section{ALL ABOUT GRAPES.}

The following papers were read and discussed at the twenty-eighth annual meeting of the Kansas State Horticultural Society:

William Cutter, Junction City, Geary county: Grapes wintered well, in spite of a few days of twenty degrees below zero. Spring opened early and warm, and tender varieties had to be uncovered by March 1. Although the grape is one of the earliest fruits to begin growth, even in the North, yet I lay down and cover all my tender varieties. The dry season caused small size and poor flavor, but it prevented rot. Of sixty bearing varieties, we find Concord the best in its season; Telegraph, best early; Worden, best ripening between them; Moore's Diamond and Missouri Reisling, best white; Woodruff, the most promising red. Of promising new grapes, Campbell's Early, Carman (a late variety), Brilliant and Croton are entitled to notice. Scientific pruning is not essential. There is an increased demand for vines, and before long every farmer will have an abundance of grapes for his home use.

Peter Moyer, Fort Scott, Bourbon county: The land should be trenched eighteen to twenty-four inches deep. A good fertilizer, such as bones, partly decayed wood, etc., should be put in the bottom of the trenches. In filling, put the 
poorest subsoil on top, to prevent surface roots. Select two-year-old plants, and set six feet apart, in rows eight feet apart, preferably north and south. Cultivate well; it pays. Trellises should be so arranged as to have the foliage cover the fruit, protecting it from rain and summer sun. This is best done by placing the wires in a triangular manner. I prefer trellises of wood not over four feet high. Prune while the sap is down. Close pruning insures better quality; leave one to three eyes to each last year's spur. Summer prune directly after the bloom falls. "Tip" the vine at the joint above the last cluster set. Thin out the weak shoots; keep well ventilated below. A pint of unleached wood ashes at base of vine is the best stimulant I have found, and it also repels insects. Adherence to these rules has, in the past twelve years, given me bountiful crops each year, with no mildew, black rot, bird's-eye rot, or any withered by drought.

E. P. Fisher, Sterling, Rice county: I am testing sixty varieties, and will classify them. In the first class I will place, as hardy, vigorous, and productive, Worden, Concord, Moore's Early, Telegraph, Jewel, Champion, Martha, Niagara, Pocklington, Early Victor, Eaton, Etta, Antoinette, Isabella, Victoria, Jessica, Green Mountain, Moyer, Ives, and Catawba. Fine table varieties: Diamond, Berckman's, Jefferson, Delaware, Willis, Oriental, Witt, Mills, Empire State, Ulster Prolific, Vergennes, Duchess, Prentiss, Triumph, Lindley, Goethe, Newton, and Brighton. I have the following new kinds to fruit next season: Geneva, Rockwood, Esther, Eaton, Ozark, White's Northern Muscat, Early Ohio, Carman, and Colrain. I have several seedlings of my own. I especially recommend Victoria as a late white grape; also Etta (very late), quality excellent. If Ozark does as well next season as this, I shall consider it a great acquisition. It is said to be very late, good size, and good quality. I am pleased with Worden; it is larger and better than Concord, but no earlier here. Its fault is poor shipping quality. Brighton is a sure and abundant bearer (if protected in winter), of fine quality. The best keepers and shippers are Mills (black), Duchess (white), and Vergennes. Red Catawba and Jefferson are good keepers and shippers. Worden and Berckman's seem deficient in firmness. Telegraph is inclined to overbear. I picked ripe Jewel July 21, and Etta were not all ripe when struck by frost, October 8. Etta is reliable, good bearer and the best late white. Moyer is a small, red grape, of excellent quality, ripening with Moore's Early. Herbert, Wilder and Iona are fine grapes, and will succeed here with a little winter protection. The Wilder is probably the best.

\section{DISCUSSION.}

Prof. S. C. MAson: Eldorado and Lady are good varieties, but each requires winter protection. I have not observed a lack of pollinating power.

F. Holsinger: Moore's Early, Champion, Concord, Goethe and Worden are all the varieties needed. I see no use of a long list, as mentioned. I would plant no white variety; they do not sell as well as Concord. For profit, Concord, Champion and Worden cannot be surpassed.

Prof. S. C. MASON : I would reluctantly offer Champion to a visiting friend.

The President: Major Holsinger treats his friends with such varieties as Goethe and Martha.

B. F. Sмгтн: We should all try new sorts as they are offered. By so doing we may find varieties better than we are growing.

The President: I would prefer Rochester, if confined to one variety other than Concord. It is a very fine table sort, handsome, ranking next to the Delaware in flavor. The vine is always strong and vigorous with me. Francis B. Hays ranks next. Etta is worthy our culture; is a heavy bearer and nice for table use.

E. J. Holman: Ives is a profitable sort. 


\section{MORE ABOUT GRAPES.}

The following papers were read and discussed at the twenty-ninth annual meeting of the Kansas State Horticultural Society:

William CutTer, Junction City, Geary county: The grape crop of 1897 was an abundant one, both east and west. The result has been extremely low prices. Growers are not very enthusiastic; no large vineyards are being planted. Still, the abundant crop has encouraged farmers to plant more, and the demand for vines is quite heavy. Many new varieties have proven comparatively worthless. I am sorry to say that quality has no chance when compared with size. Concord establishes the price, and Worden, Diamond, Agawam, Wilder, Brighton and others have to fall in line. Small grapes, particularly white ones, bring up the rear, at prices that hardly pay for picking. I will not give a detailed account of the many varieties I have bearing this year, but I will mention a few of the more worthy. Concord still leads for market, and for the farmer (who usually neglects his vines) there is no other variety that will pay as well. Still, we should not be satisfied with one variety only. It is as easy, and more pleasant and profitable, to have grapes for use three months as for only three weeks; besides, you ought to have black, white and red varieties. Tastes differ, only the grower is a good judge of any kind of fruit. Moore's Early is the earliest grape worthy of cultivation, and it is a poor bearer. Telegraph comes next, and is hardy and productive, a fair table grape and a good shipper. Worden comes before Concord, and, while one of the best table grapes, the skin is too tender for market; it sells above Concord in country towns. Woodruff, Agawam and Catawba are worth all the rest of the good grapes. Mcore's Diamond, the best white grape, is large, hardy, productive, and of good quality, but does not last long; and, excepting a few for home use, no other white grape has any value. The Empire State and Green Mountain are both good, but will not pay for extra cost of growing. Never plant grapes on a southern slope in central Kansas; a clay subsoil is preferable.

B. F. Sмiтн: With grapes, we get the least money for the work done. My neighbors grow them; I do not. They work, spray, pick, prune, and furnish the filled baskets - all for ten cents. Is there any money in that? I would not discourage grape growing, but I think it is throwing away time and money.

J. L. Williams: I was at the vineyard of a Jackson county grape grower when he had a large crop of grapes. I asked him what he would do with them? He said: "Sit up nights and eat them." A pretty good idea ; for I think them very wholesome, and that they should be grown for home use. When I first raised grapes, I got twenty cents a pound for them; but now they sell at two or three cents a pound, and it does not pay.

Secretary Barnes: Two or three cents per pound is a good price for grapes; but when they get down to three-quarters of a cent they do not pay. They do little good in cold storage. We should raise a crop that ripens later. Our grapes are ripe and all gone while the weather is yet hot. If we could grow a grape to ripen after all other grapes are gone, they would pay well. Grapes from New York, and other places sell here at five to eight cents a pound a few weeks after our grapes were sold for three-quarters of a cent a pound. We should correct this by growing a very late grape.

C. C. Cook: I raise Concords, and when I want them early I trim the foliage closely, and let the sun ripen them. I sometimes keep them until November.

T. W. Harrison: Is it any more work to raise an acre of grapes than an 
acre of corn? It does not take any more muscle or brain ${ }^{\prime}$ work. You get $\$ 100$ an acre for grapes, and $\$ 7$ to $\$ 8$ an acre for corn. Seeing a Grantville man selling grapes at one cent per pound, I asked him if he could afford it? $\mathrm{He}$ answered, "It 's $\$ 100$ an acre just the same." I do not think it is near the work to grow grapes as it is corn, and you make more profit.

F. Holsinger: All should raise grapes for family use, if not for market. The question has been asked, "How can we keep them from ripening so early?" I put mine in paper sacks [on the vine] last year, and the result was we had grapes a month later than usual. I did not sack them early enough to prevent a little rot from getting on them.

William Cutter: The Concord may be left on the vines long after most people think they must be marketed. Many vines are stripped [of grapes] before fully ripe; some drop off, but what do stick improve as long as they hang on. My Catawbas hang on the vines very late. The only loss from letting them hang long is by grasshoppers and bees.

JAMes MCNicol, Marion county: I raise more Worden than Concord. Cutter speaks about picking grapes not fully ripe. If I can get one-half a cent more [per pound] for green grapes, I sell them. The first brought me twenty cents per basket; two or three days afterward I could get only fifteen cents.

T. W. Harrison: Moore's Diamond is as delicious a grape as I ever tried. Some do not succeed with it. It does splendidly with me; ripens very early, and gets into the market before the Concord. Worden is also a fine grape. Mr. Buckman has many varieties. If he will tell about them, we will appreciate it.

A. H. Buckman, Shawnee county: I have many varieties planted for experimental purposes, and not for profit. My two boys think a great deal of them; getting them interested in grapes helps to keep them on the farm, and thus I succeed better. My returns have been in pleasing my boys. I think they pay me as well as anything on the farm. Moore's Early has paid pretty well, and Moore's Diamond also. I think the Eaton the most successful with me. The Green Mountain, a very sweet, little, white grape, I have no doubt would sell well on the market. It ripens about the 1st of August, and is an awful good bearer. I have Early Ohio which were ripe the 1st day of August. The Green Mountain comes about a week later. Early Ohio is the earliest grape I know, excepting one our friend, Mr. Entsminger, at Silver Lake, has, and calls his "Daisy," which ripens about the $2 \mathrm{~d}$ of July. The Brighton is a good grape, and always a seller. What I am looking for is a grape a little better than any now grown. My boys say they prefer Moore's Early, Woodruff Red, and Goethe. I have many grapes which I think better than Concord. It pays, and is not a very big job to trim grape-vines.

George P. Whiteker, Shawnee county: The grape crop of 1898 was about one-half what it was in 1897, as near as I can learn. Some vineyards that yielded heavily last year proved almost a complete failure this. The grapes this year rotted and dropped off badly. Many attribute this to the heavy rains last spring; our limited experience in grape growing does not permit us to express an opinion regarding the matter. In 1894 we planted a vineyard of twenty acres; last year we gathered 14,900 eight-pound baskets, which we sold at an average of ten cents per basket, making a total of $\$ 1490$; counting off ten per cent. commission for selling, cost of basket two and one-half cents, one cent per basket for picking, we have the total cost of marketing, which is $\$ 670.50$; net on the 14,900 baskets, $\$ 819.50$. This season the same vines yielded only 7178 baskets; less than one-half what they yielded last season. This year we sold our grapes at an average of fourteen and one-half cents per basket, making a total of $\$ 1040.81$. 
Total expense of same, including baskets, commission, and picking, same as last season, \$355.31; making net, \$685.50. While our crop last year was almost double what it was this season, our actual gain was only $\$ 134$, as you see.. The large yield last year caused the price to drop, while the expense of marketing was almost double that of this year. 'We believe, for the money and labor spent, our grapes yield the largest returns of any crop we raise, excepting peaches. These, of course, are not always a sure crop. From our experience, we find it does not pay to put grapes in cold storage, as the New York grapes come into market immediately after grapes are done here. The first New York grapes we bought this season cost us twelve and one-half cents laid down here, and were of superior quality.

Mr. Dukelow, Reno county: I have twenty acres of grapes, and I find four kinds that pay: Moore's Early, Culver, Catawba, and Niagara. I have some other varieties, but they do not amount to anything. Only these four are any good. The best is Moore's Early, an excellent bearer, and of good quality. I shipped a good many grapes to Oklahoma City.

Question: Did you get any better prices for them down there?

Answer: I ship Catawbas mostly. I do n't get any more for them than I did for Moore's Early.

Q.: Did you ever raise the Champion?

$A$.: Yes, sir, some years ago; and I never gathered the last crop at all; they did little good.

Q.: How much difference in the time of ripening is there between Moore's Early and other grapes?

A.: Moore's Early are all gone before the others commence.

J. L. Williams, Jackson county: I have been raising a few grapes for my own use more - particularly for myself and for home use - and it do n't pay. The most profitable grape with me is Moore's Early. It comes before the Concord, and I get better prices for it than for any other. For the Concord, for the last two years, we got about one cent a pound. I have trouble to sell them all. One year I made some wine for church use, and they paid six cents a pint; at that rate I received twenty-one cents a pound [basket?] for the grapes.

A Delegate: A valuable grape that has not been mentioned is the Wirt; it comes in right after Moore's Early, bears heavy, and is generally ready for market before the first Concords. It is a heavy bearer, and best-flavored grape I know. Last year was the first time it failed to ripen ahead of the Concord; this year it came in with the Concord. The Niagara is another good grape. It is a heavy bearer, and I think the only profitable white grape.

F. W. Dixon, Jackson county: We grow a few grapes, simply for our own use. I have only Concord, Niagara, and Moore's Early. Moore's Early and Niagara will bear ten pounds where Concord bears one. I had a fine crop of grapes until the little birds got at them, and in a few hours they used them up. They were the golden robin and sparrow; they came to the grapes in clouds.

A. L. Brooke, Shawnee county: I do n't know a little bit about grapes, but I want to tell something good that some other men know. If you want a good grape, one that is better than any other grape, raise Norton's Virginia.

F. Holsinger: I am located in town, and when my grapes ripen the sparrows take them; they soon destroy the whole crop. You can remedy that by sacking the grapes; it won't pay to sack grapes, excepting a few for home'use; but you can preserve them in that way. There is much to be said in favor of sacking grapes. The proper time is when the blossom has fallen. [When the size of bird shot.-SEC.] I usually take two-pound paper sacks. They sell for forty- 
five cents a thousand, and where they are conveniently together I put two bunches in each sack. It will also stop insect ravages. I also have grapes in. the country, but the birds do not bother them much. If you are living in town. it will pay you to sack your grapes.

Mr. Dukelow: Plant white Kafir-corn close to the grapes, so that it will be ripe at about the same time as the grapes are. It is a great preventive. The birds will eat the seeds of the Kafir and let the grapes alone.

J. W. Robison, Butler county: How many acres of Kafir-corn would it take to protect an acre of grapes near Kansas City?

W. L. HaLL, Riley county: We have 160 varieties of grapes under test at the experiment station, at Manhattan. One variety I wish to mention favorably - it. is the Eldorado. It ripens about with the Concord. It does not have the cluster or bunch of the Niagara, but in quality it far exceeds the Niagara. We have: shown them to many persons, and on testing, they pronounce them better in every way than anything else.

Question: Have you the Columbian in your collection?

Answer: Yes, sir; there is a jar of them on the table. They are very hardy, and promise to make a good grape for market. It is as large, if not larger, than any we have. I have measured them one and one-fourth inches in diameter. It originated in Ohio.

Q.: Do you consider it a valuable grape?

$A .:$ If the people can get a chance to taste, it will sell all right.

A. H. Buckman, Shawnee county: I have no grapes to sell, but I want to say a good word for the Green Mountain and Diamond. I grow the Niagara, and it is seldom profitable. I consider it no better than the Rogers or some others. It is not as hardy as Green Mountain. The Green Mountain is the earliest grape we have. It comes before Moore's Early, and there is no question as to its quality.

William CutTer: I have about seventy-five varieties of grapes; among them is a seedling of my own that ripens after all others that I have; but it ripens imperfectly in many parts of Kansas. If it ever becomes of value, it must ripen a little earlier or be planted farther south. It is much like the Concord when ripe. The bunches are very large. Two other grapes have, I think, been slighted here. One is Moore's Diamond, the most productive grape I have, but a poor keeper. The Green Mountain is too small, excepting for children to eat. The Campbell's Early bore with me this year before Moore's Early. It is smaller in size than Moore's Early, but the bunch is larger. It is a good keeper.

\section{VINEYARDS.}

The following was read and discussed at the thirty-third meeting of the Kansas State Horticultural Society, 1899:

M. E. Chandler, Argentine, Kan.: The grape crop was not very encouraging for the majority of growers in the vicinity of Kansas City. This was due to the extreme cold of winter and the rot of summer. The crop was reduced to about thirty per cent. Vines have grown well this summer and are in fine condition for a crop next year. Grapes affected with black rot were mostly on black soil or high prairie. With us, on sandy, clay soil, the rot was less than five per cent. and the crop about twenty-five per cent. The black rot is carried through winter in the dried grapes and leaves. The black rot is first visible as a brown speck, spreading throughout the vine. The spores are carried through the air and germinated with the presence of water. Downy mildew is a parasitic plant 
running through the tissues of the vine, and appears on the side of the leaves as a whitish spot. Another disease is anthracnose, of European origin, which attacks the leaves, twigs, and green shoots; its common name is bird's-eye rot. It first attacks the fruit; as it progresses it leaves bits of diseased tissue upon the shoots and leaves. It is related to black rot. Remedies for the above diseases: Spray with copper sulphate for black rot, and Bordeaux mixture for downy mildew, and ammoniacal solution of copper carbonate and kerosene emul. sion for anthracnose (six ounces pulverized ammonia carbonate and one ounce of copper carbonate, in ten gallons of water). Grapes should be sacked to keep in perfect condition. Agawam, Goethe, Lindley, Wilder, Salem and Delaware were killed to the ground. Champion was injured. Diseased grape-vines should be trimmed in the fall, [and the trimmings] raked up and burned. Spray early in the spring, when the buds begin to swell. As commercial grapes, I would recommend Moore's Early, Worden and Concord for black; as table grapes, Niagara, Moore's Diamond and Green Mountain for white, Moyer, Delaware, Lindley and Goethe for red and pink. New grapes are Campbell's Early and Green Mountain.

Mr. KenOYER: In regard to the speaker's recommendations of three different spray materials, all virtually the same, for the three different grape diseases he mentions, it seems to me it would require so much spraying that it would not be profitable. By using the one mixture, which contains virtually the same fungicide that the other two contain, the one spraying for all diseases would "kill all three birds at one shot."

Mr. Chandler: I advised using the copper-sulphate early in the spring, and after the leaves were out I would use the Bordeaux mixture.

Mr. Kenoyer: In using the copper-sulphate solution, most of us cannot afford to buy a barrel spray pump; but if we use one that is not copper-lined throughout, with that mixture, without the lime, we would destroy our pump in one season, while putting the lime in would make it last for perhaps eight or ten years, and, with the lime in it, the mixture will accomplish the same end and save our pumps.

\section{WHY SOME GRAPES FAIL TO FRUIT.}

By F. H. HALL, in Bulletin No. 157 of New York Agricultural Experiment Station.

Careful observation among grape culturists long ago noted the fact that some varieties failed, for unknown reasons, to set fruit. Barry, Herbert, Brighton, Eumelan and several other varieties, when set alone in vineyards, or in blocks remote from other sorts, proved shy bearers, producing only a few bunches of a straggling character, or were complete failures. These same grapes, in vineyards no more favorably located but composed of mixed varieties, gave heavy yields of large and complete bunches. What caused this? Every grower knows that certain varieties of strawberries will not fruit when set alone, because the stamens which should furnish the pollen, or male element, are lacking. The flowers of cultivated grapes, however, are perfect, so the defect in this case is not evident to any casual inspection. It had been suggested that the flowers of these capriciously fruiting varieties are self-sterile; that is, that they will not become fruitful under the influence of pollen from flowers of the same variety; but no systematic investigation on this subject had been made previous to this station's work.

Do these varieties known to be shy bearers require pollen from other varieties to insure fruiting? If so, how general is this defect among the cultivated varie- 
ties and which sorts belong to the defective class? What is the cause of this condition, and how may its existence in any variety be recognized? To answer these queries and other associated ones, the station in 1892 began a series of observations and experiments and has continued the work each year since that time.

The method used was simple, but the amount of work required great. Vines of the different varieties in apparently healthy, productive condition were selected, and two or more well-formed flower clusters on each vine were enclosed, before the flowers opened, in manila paper bags. [See page 18 of this book.SEc.] When the flowers open, as they do perfectly although bagged, they can receive pollen from no other variety; that is, they must become self-pollinated, not cross-pollinated.

If they produce fruit under these conditions the variety is self-fertile; but if, repeatedly, in different years and in different vineyards, the flowers bear no fruits or but a few straggling berries, the variety is self-sterile, or practically so.

In the tests carried on in four vineyards at Geneva, one at Branchport, and one at Penn Yan, and continued for seven years, 169 cultivated varieties have been under experiment. One-fourth of the varieties have borne perfect, compact clusters in the bags; more than one-third produce clusters not quite perfect but still marketable; about one-sixth of the varieties produce a few fruits, but not enough to make salable bunches; and nearly one-fourth of all tested produce no fruit whatever when cross-pollination is prevented. The list of varieties thus classified follows.

Those marked 1 bloom very early; 2, medium early; 3 , middle of the season; 4, late; 5, very late. Those marked with a star are described elsewhere in this book.

Class 1.-Clusters perfect, or varying from perfect to somewhat loose.

3 Ambrosia.

3 Antoinette.

*2 Berckman's.

3 Bertha.

3 Columbia.

*3 Cottage.

*3 Croton.

*3 Delaware.

*4 Diamond.

*3 Diana.

5 Early Golden.

2 Etta.

3 Herald.
5 Hopkins.

* 1 Janesville.

* 4 Lady Washington.

3 Leavenworth.

2 Lutio.

3 Mabel.

Marvin Seedling White.

1 Mary Favorite.

4 Mathilde.

4 Metternich.

4 Monroe.

* 4 Moore's Early.
*4 Niagara.

4 Opal.

*4 Poughkeepsie.

*3 Pocklington.

3 Profitable.

* 4 Prentiss.

*4 Rochester.

3 Rutland.

Senasqua.

3 Shelby.

*3 Telegraph.

3 Winchell.

*3 Worden.

Class 2.-Cluster's marketable; moderately compact or loose.

\footnotetext{
*3 Agawam.

3 Alice.

3 Arkansaw.

5 Bailey.

5 Big B. Con.

5 Big Extra.

*3 Brilliant.

2 Brown.

4 Burrows's No. 420.

* 4 Carman.

* 4 Catawba.

2 Caywood's No. 50.

*4 Centennial.

* 2 Champion (Cortland).
}

\author{
* 3 Chandler. \\ 3 Chautauqua. \\ *1 Clinton. \\ *3 Colerain. \\ * 4 Concord. \\ 5 Dr. Collier. \\ *3 Duchess. \\ 3 Early Market. \\ *3 Early Ohio. \\ *3 Early Victor. \\ 3 Edmeston's No. 1. \\ 5 Elsinburg. \\ *2 Elvira. \\ *3 Empire State. \\ 3 Esther.
}

5 Fern Munson.

3 Glenfeld.

4 Golden Grain.

*3 Hartford.

4 Highland.

4 Hopican.

3 Illinois City.

*3 Iona.

4 Isabella.

3 Isabella Seedling.

*4 Jefferson.

* 4 Jessica.

* 4 Lady.

4 Leader.

4 Lindmar. 
3 Little Blue.

3 Livingston.

3 Marie Louise.

*3 Mills.

*3 Missouri Reisling. Norfolk.

3 Olita.

3 Paradox.
Class 2-concluded.
*3 Paragon.
*3 Perkins.
3 Rockwood.
3 Rogers's No. 13.
3 Rogers's No. 24.
3 Rogers's No. 32.
*3 Rommel.
3 Shull's No. 2.
3 Standard.
4 Triumph.
* 2 Ulster.
*3 Victoria.
3 Wheaton.
3 Witt.

4 Adirondack.

3 Alexauder Winter.

3 Amber Queen.

2 Beagle.

5 Big Hope.

*4 Brighton.

Canada.

4 Canonicus.

3 Daisy.

Class 3.-Clusters unmarketable.

4 Denison.

*3 Dracut Amber.

*4 Eumelan.

* 4 Geneva.

4 Gold Dust.

* 4 Hayes.

*4 Lindley.

1 Marion.

3 Nectar.
*2 Noah.

*3 Northern Muscadine.

3 Norwood.

3 Pearl.

4 Roenbeck.

3 Thompson's No. 5.

3 Thompson's No. 7.

* 4 Vergennes.

*3 Woodruff.

Class 4.-Self-sterile; no fruit develops on covered clusters.

4 Aledo.

3 Amber (?).

4 America.

3 Aminia.

*3 Barry.

4 Black Eagle.

4 Blanco.

4 Burnet.

1 Clevener.

3 Creveling.

5 Dr. Hexamer.

* 4 Eaton (?).

* 4 Eldorado.
2 Elvibach.

3 Essex.

2 Faith (?).

4 Gaertner.

*3 Green's Golden.

*3 Herbert.

3 Hercules.

*3 Jewel.

4 Juno.

* 4 Massasoit.

3 Maxatawney (?).

*3 Merrimac.
3 Montefiore.

3 Oneida.

3 Red Bird.

Red Eagle.

3 Requa.

4 Rogers's No. 5.

4 Roscoe.

4 Rustler.

*3 Salem.

2 White Jewel.

* 4 Wilder.

*3 Wyoming.

The first two classes include the great majority of commercially profitable varieties. Since the varieties in classes 3 and 4 will not fruit well when standing alove, they should be planted beside other grapes which bloom at the same time. As a guide to the blooming season, figures 1, 2, 3, 4 and 5 have been placed opposite varieties in bloom at approxinately the same date. Grapes belonging to the vulpina (riparia) species, river grapes, of which Clinton and Marion are examples, are first in bloom; then the asstivalis species, summer grapes, of Mills and Ulster type; later, the fox grapes, or labruscas, Concord, Isabella, etc.; and last, the post oak grapes (Vitis lincecumii), and other species whose natural home is the Southwest. There is, of course, no marked line of separation between the groups given, many of the earlier varieties extending their period of bloom nearly as long as other varieties in the group following, so that early bloomers might be fertilized to some extent by a later class.

The physiological explanation for this condition of self-sterility has not been absolutely determined, but the failure is probably due to a lack of affinity between the pollen and pistils of the same variety. It is a phenomenon very similar to the failure of mules and other hybrids to breed, and probably due to the same causes; for most, if not all, the varieties found to be sterile or nearly so are hybrids between different botanical species of grapes.

All of the perfect-fruiting varieties were found to have long stamens; and all varieties which had short stamens, as well as a few which had long stamens, gave imperfect fruit or none at all. "The fact that a variety has short stamens may be taken as pretty sure evidence that it is self-sterile"; but, as stated, not all varieties with long stamens are self-fertile. 


\section{DO BEES DESTROY GRAPES?}

Many of our vineyardists claim that bees destroy grapes, and the matter has been a source of debate and discussion in all neighborhoods where bees are kept and grapes are grown. We have looked up authorities on this subject, and offer the following extracts :

From "Bee-keeping in Relation to Horticulture," read before the Kansas State Horticultural Society, by Emerson Taylor Aввотт, of St. Joseph, Mo.

"Many fruit-growers persist in saying that bees do injure ripe fruit, especially the grape. They have been accused of eating up the fruit of entire vineyards, and some claim that they have destroyed apples, pears, plums, and, possibly, corn and pumpkins.

"Now, what are the facts? Do bees ever suck the juice of grapes? Yes, when the grapes burst from overripeness, or when punctured by other insects, as wasps and hornets, they will suck every drop of juice. When grapes are left on the vines until overripe, as is often done, and there are many bees near, they become troublesome, if not dangerous, to those engaged in gathering the fruit. It yet remains to be proven that the honey-bee ever injured any sound fruit orpunctured a perfect grape.

"A few years ago the United States government employed a special agent to" investigate, and, after repeated tests and experiments, he said: 'My observations and experiences with bees in confinement and those having free access to vineyards furnish abundant proof to convince me that bees do not and cannot injure sound fruit.' This man was not influenced by selfish interests, and had no reason for making any false statement. All unbiased testimony since corroborates his statement. I have tested the matter with nearly 200 colonies of bees by the side of a two-acre vineyard, from which I harvested a large crop of ripe grapes, and with this experience of my own, and the testimony of others to bear me out, I say bees never injure sound fruit. The bee is not built that way. While its mandibles are very strong, yet they are not suited to cutting, as any one can see by examining them with a microscope. The jaw is not notched, but perfectly smooth, and bears nothing that resembles teeth. It would require teeth like a squirrel in order to do much that is charged to it."

From Langstroth on "The Hive and Honey-bee," 1899.

"Aristotle remarked, more than two thousand years ago, that bees hurt no kind of sound fruit, but wasps and hornets are very destructive to them. This accusation of bees injuring fruit has become of so much importance in the past few years, especially in the best fruit and bee country of the world, California, that we deem it necessary to give it a whole chapter. While the honey-bee is regarded by the best-informed horticulturists as a friend, a strong prejudice has been excited against it by many fruit-growers, and in some communities a man who keeps bees is considered as bad a neighbor as one who allows his poultry to despoil the gardens of others. Even some warm friends of the "busy bee" may be heard lamenting its propensity to banquet on their beautiful peaches and pears and choicest grapes and plums. That bees do gather the sweet juice of fruits when nothing else is to be found, is certain; but it is also evident that their jaws, being adapted chiefly to the manipulation of wax, are too feeble to enable them to puncture the skin of the most delicate grapes.

"We made experiments in our apiary on bees and grapes during the season of 1879 - one of the worst seasons we ever knew for bees. The summer having been exceedingly dry, the grape crop was large and the honey crop small. In 
every vineyard a number of ripe grapes were eaten by bees, and the grape growers in our vicinity were so positively certain that the bees were guilty, that they held a meeting to petition the state legislature for a law preventing any one from owning more than ten hives of bees. This serious charge called our attention to the matter, and we decided to make a thorough investigation in our own vineyard. But, although many bees were seen banqueting on grapes, not one was doing any mischief to the sound fruit. Grapes which were bursted on the vines or lying on the ground, and the moist stems from which grapes had recently been plucked, were covered with bees; while other bees were observed to alight upon bunches which, when found by careful inspection to be sound, they left with evident disappointment. Wasps and hornets, which secrete no wax, being furnished with strong, saw-like jaws for cutting the woody fiber with which they build their combs, can easily penetrate the skin of the toughest fruit. While the bees, therefore, appeared to be comparatively innocent, multitudes of these depredators were seen helping themselves to the best of the grapes. Occasionally a bee would presume to alight on a bunch where one of these pests was operating for his own benefit, when the latter would turn and - show fight,' much after the fashon of a snarling dog molested by another of his species while daintily discussing his own private bone.

"During grape picking, the barrels in which our grapes were hauled to the wine-cellar were covered with a cloud of bees feeding on the damaged clusters, and they followed the wagon to the cellar. After removing the barrels to a place of safety, we left one bunch of sound grapes on the wagon, puncturing one of the grapes with a pin. This bunch, being the only one remaining exposed, was at once so covered with a swarm of bees that it was entirely hidden from sight. It was three o'clock in the afternoon. At sunset the bees were all gone, excepting three, who were too exhausted to fly off. The bunch had lost its bloom; the grapes were shiny, but entirely sound. The one punctured grape had a slight depression at the pin-hole, showing that the bees had sucked all the juice they could reach, but they had not even enlarged the hole. We also placed bunches of sound grapes inside of some four or five hives of bees, directly over the frames, and three weeks after we found that the bees had glued them fast to the combs, as they glue up anything they cannot get rid of, but the grapes were perfectly intact.

"Mr. McLain, in charge of the United States agricultural station, was instructed to test this matter thoroughly by shutting up bees with sound fruit, and the result was the same as in our case. [See elsewhere.] The main damage to grapes is done by birds; hence, the borders of a large vineyard are first to suffer, especially when in proximity to hedges, orchards, or timber. Even in small cities the number of birds that feed on fruit is extraordinary, and one can have no idea of their depredations until he has watched for them at daybreak, which is the time best suited to their pilfering. After the mischief has been begun by them or by insects, or wherever a crack or spot of decay is seen, the honey-bee hastens to help itself, on the principle of 'gathering up the fragments, that nothing may be lost.' In this way they undoubtedly do some mischief, but they are, on the whole, far more useful than injurious."

\section{From "Bee Keeper's Guide," by A. J. Cook, 1899.}

"Bees gather juices of questionable repute from grapes and other fruit which have been crushed, or eaten and torn, by wasps and other insects. That bees ever tear grapes is a question of which I have failed to receive any personal proof, though for years I have been carefully seeking it. I have lived among the vineyards of California, and have often watched bees about vines in Michigan, but 
never saw bees tear open grapes. I have laid crushed grapes in the apiary, when the bees were not gathering, and were ravenous for stores, which, when covered: with sipping bees, were replaced with sound grape clusters, which in no instance were mutilated. I have even shut bees in empty hives, on warm days, and closed the entrance with grape clusters, which even then were not cut. I have thus. been led to doubt if bees ever attack sound grapes, though quick to improve the opportunities which the oriole's beak and stronger jaws of wasps offer them. My friend, Professor Prentiss, suggests that when the weather is very warm and damp, and the grapes very ripe, the juice may ooze through small openings of the grapes, and so attract the bees. It is at just such times that attacks are observed. I feel very certain that bees never attack sound grapes. I judge not only from observation and inquiry, but from the habits of the bee. Bees never bore for nectar, but seek, or even know, only of that which is fully exposed."

The above ought to convince any one that bees do not eat or injure sound grapes or fruit, although several of our intelligent correspondents seem to think they do. Some of them will no doubt be surprised on reading the above, and declare that western bees - Kansas bees - are a different variety, and, like the late lamented colored preacher, who declared to his dying day that " the sun do move," they will still declare that "bees eat grapes." I heard a horticulturist, at a regular meeting of the Douglas County Horticultural Society, declare that "bees ate anything, even young ducks"; and he added, "they would eat a dead horse and. polish his bones." - SEC.

\section{REPORT ON APICULTURE.}

By Nelson McLain, of the United States Agricultural Station at Aurora, Ill. Taken from the Report of the United States Commissioner of Agriculture, 1885.

BeEs vs. Fruit.-For the purpose of testing the capacity of bees, under exceptional circumstances, to injure fruit, we built a house sixteen feet long by ten feet wide, and eight feet high at the corners. Large doors were hung in each end, and a part of the siding on each side was adapted to be raised up on hinges. Screen doors were hung on the inside of the outer doors, and wire cloth covered. the openings on the sides, where the siding was raised. The house is entirely bee-proof. When the sides are raised up and the outer doors opened, the temperature and light in the house are substantially the same as outside. Along the sides of the house we built shelves upon which fruit was placed so that the rays. of the sun might strike the different varieties in different stages of ripeness, from. green to dead ripe. Plates of ripe peaches, pears, plums, grapes, etc., were placed on the shelves; clusters of different kinds of grapes, green and ripe, sound and imperfect, and such as had been stung by insects, were suspended from the rafters and crossties of the house.

The 1st of September we removed three colonies of bees from their hives, carefully and quickly, so that they would carry very little honey with them when transferred from one hive to another. Two of the colonies were hybrid bees, and one Italian. These colonies were hived on empty combs, and placed in the house with the fruit. A wood stove was put in the house, and for a number of hours: each day a high temperature was maintained. The physical conditions which would ordinarily prevail in nature during a protracted and severe drought were. artificially produced and steadily maintained.

The bees were brought to a stage of hunger, thirst, and starvation. The house was kept locked, and we carried the key. Every inducement and oppor- 
tunity were afforded the bees to satisfy their hunger and thirst by attacking the fruit exposed. They daily visited the fruit in great numbers, and labored diligently to improve the only remaining source of subsistence. They inspected and took what advantage they could of every opening at the stem or crack in the epidermis or puncture made by insects, which deposited their eggs in the skin of grapes. They regarded the epidermis of the peaches, pears, plums and other fruits having a thick covering simply as subjects for inquiry and investigation, and not objects for attack. If the skin be broken or removed, they will, in case of need, lap and suck the juice exposed. The same was also true of the grapes; if the skin be broken by violence or burst on account of the fruit becoming overripe, the bees lapped and sucked the juice from the exposed parts of the grapes and stored it in the cells for food. They made no attempt to grasp the cuticle of grapes with their mandibles or with their claws.

If the grapes were cut open or burst from overripe, the bees would lap and suck the juice from the exposed segments of the grape, until they came to the film separating the exposed and broken segments from the unbroken segments. Through and beyond the film separating the segments they appear to be unable to penetrate. I removed the outer skin from many grapes of different kinds, taking care to not rupture the film surrounding the pulp. When these were exposed to the bees, they continued to lap and suck the juice from the outer film until it was dry and smooth as was the film between broken and unbroken segments. They showed no disposition to use their jaws or claws, and the outer film, as well as the film between broken segments, remained whole until the pulp decayed and dried up.

After continuing the test for thirty days, using such varieties of fruit as could be obtained, we sent to Michigan for varieties not obtainable here. Through the kindness and favor of the president of the Michigan Horticultural Society, Mr. T. T. Lyon, of South Haven, Mich., we secured twenty varieties of grapes, which arrived in excellent condition. Another colony of Italian bees was then placed in the house with those already confined for forty days, and the twenty varieties of grapes were exposed upon plates and suspended from the rafters as before. The conditions naturally prevalent during a severe and protracted drought were again produced, and test again continued for twenty-five days. The result was simply a repetition of the former test.

The bees showed no more capacity or disposition to offer violence to one variety of grapes than another. No more attention was given the thin-skinned varieties than the thick-skinned. As long as the skin remained whole they did not harm the grapes. When the skins were broken by violence, such as by cutting or squeezing, the juices exposed were appropriated. The extent of the damage bees could do to grapes burst from overripeness depends on the extent of the rupture in the film surrounding the pulp. A wide rupture may be made in the epidermis, or it may be removed, and if the film is unbroken the pulp remains whole. The film seldom bursts until the grape is about to decay, or has begun to decay, and then the grape is of little value. In order to determine the size of the opening necessary to be made in order that bees might injure grapes, we punctured the cuticle of the grapes in several bunches with cambric needles of various sizes. The puncture made with the point of medium-sized needles produced no effect. Neither does the puncture made by the sting of insects when ovipositing, until the blister appears and decay progresses with the development of insect larvæ. I found that I might pass a medium-sized needle through a grape from side to side, and bees could obtain no juice excepting that 
oozing from the puncture. Many erroneously suppose that bees sting the grapes. Bees never sting excepting in self-defense or in defense of their homes from real or imaginary danger.

At times when bees could gather nothing in the fields, we saturated clusters of grapes with honey and suspended them in front of the hives in the apiary, and from branches of trees and grape-vines near by. Other clusters, dipped in honey and syrup, were hung in the house. The bees thronged upon the grapes until the clusters looked like little swarms hanging to the vines and limbs. They lapped the grapes until the skins were polished perfectly smooth and shining, like the inside skin of an onion, and no taste of sweet could be detected by touching the tongue to the grape. The skins of the grapes were left intact.

Bees, like some animals of higher order, seem to enjoy stolen sweets better than any other. Taking advantage of their propensity to steal and despoil, we placed combs containing honey in an unoccupied hive, and permitted the bees in the apiary to steal the honey and such portions of the comb as they could appropriate. We then suspended, instead of the despoiled combs, clusters of grapes dipped in honey. The bees attacked with desperate earnestness, apparently determined to literally go through those grapes. The clusters were left hanging for a day or two, until the bees had entirely deserted the hive, and examination showed the grapes to be as sound as when placed there, and the skins polished smooth and clean as before. We then punctured the grapes of several clusters, by passing a darning-needle through the fruit from side to side, and hung them in the house near the hungry bees. They sucked the juice from the broken segments as far as they could insert their tongues into the wound, leaving a depression near the puncture, and the remainder of the pulp was left whole.

The instinct of bees impels them to remove everything useless or strange from their hives. They will labor harder to remove any object which is useless or offensive than for any other purpose. After passing a darning-needle through some of the grapes in several clusters of different varieties, we suspended those clusters from the top of comb frames by using fine wire, and placed them in the center of strong colonies of both hybrids and Italians. The juice was extracted from the punctured segments as before, and the perfect grapes hung undisturbed for fifteen days. They appeared to have kept better hanging in the hive than they would have kept on the vines.

The evidence then shows that bees do not injure perfect fruit. We have observed that they give no attention to the puncture and blight caused by the ovipositing of other insects until after the larvæ have hatched and decay has set in, and then only in cases of extremity. The circumstances under which bees appear to be able to injure grapes are very exceptional. That they will not molest or even visit grapes when it is possible to obtain forage elsewhere is certain. It also appears certain that they never attempt violence to the skin of grapes.

The capacity of bees to injure overripe grapes is limited by the extent to which the juice and pulp are exposed by the bursting of the film. If the film is only slightly burst, the bees can do but little injury. If the progress of decay has caused a wide rupture in the film, the bees more readily appropriate the juice. If overripeness and decay have exposed the pulp of grapes to such an extent that bees can damage them seriously, the bees should be confined to the hive (unless the weather is excessively hot), and the grapes should be at once gathered, for, from this stage, the progress of decay is rapid. Confinement to the hive for a short time, while the overripe grapes are being gathered, would result in no loss, and the bees would be prevented from gathering the juice and storing it in the hive. Bees confined to their hives in warm weather must always have ample top 
ventilation, and should be liberated and allowed to fly half an hour before sunset each day during the term of their confinement. The excessive use of grape-juice of ten produces inebriety. In the case of bees it produces diarrhea. After grapes have arrived at the stage of overripeness and decay in which it is possible for bees to injure them, and the circumstances are so exceptional as to cause the bees to seek such food, it would be advantageous to the grape grower to secure his grapes from the ravages of decay, and advantageous to the bee-keeper to secure his bees from the ravages of disease.

\section{PROFITABLE GRAPES.}

A paper by Henry Wallis, Wellston, Mo., read at the West Plains meeting of the Missouri Horticultural Society.

The task assigned to me is greater than I am able to do perfect justice; therefore, I kindly ask for a little forbearance; and if only a few members of our society should gain profit from my personal experience expressed herein, my effort will be tenfold rewarded. Well knowing one man's owl is another man's nightingale, and vice versa, so the same grape may be a bonanza for one fruitgrower and a total failure with another, as the final result of a combination of conditions often uncontrollable. It is more or less a difficult problem, to be solved by every fruit-grower for himself, which varieties, if properly cared for, adapted to his soil, and sold fresh from the vineyard or made into wine, will give the best cash reward in near-by or distant markets.

One thing I know surely: all grapes shipped to a distant market, no matter how poor and miserable they may be, are a source of great. profit to the railroad company and the commission man, and only the skimmed, blue milk is left for the fruit-grower, provided it is not spilled entirely by some pig.

Last year a St. Louis commission firm shipped 450 nine-pound baskets of the finest Hicks grape for me to Milwaukee, Wis. They realized twelve cents per basket in Milwaukee, but gave me only fifteen dollars for the entire lot; equal to me, net, only three cents per basket, or one-third cent for each pound of the finest black grapes. So fully three-fourths of the money received by them was absorbed by the railroad company and the commission man. One of my friends received not one cent for 100 baskets of Concord grapes shipped by the same firm. The same rule applies to the Ohio and New York grape growers. Their grapes were sold last year in St. Louis, at retail; at ten cents per basket; deducting freight, commission, and retailer's profit, I ask: Did the fruit-grower receive one-half cent net for each pound of fine grapes, or even less? (Commentar ueberfluessig!) By the way, I agree with Mr. Bomberger: "There is no earthly excuse for us in Missouri buying our grapes from Ohio or New York," and I add, not even from California.

Now, what varieties are especially profitable? Last year even the poor Hartford and Ives were profitable for me; each plant had twenty to twenty-five pounds of grapes, and I netted from thirty to thirty-five cents from every twentypound basket. My neighbor sold his poor Champion for three to four cents per pound before my Moore's Early could be had. Moore's Early is profitable on account of its quality as well as earliness, even if a poor grower, producing only moderate crops. The Worden will be found profitable for the same reason, though it produces more fruit. Norton, Cynthiana, Missouri Reisling and a few others will be profitable for wine, considering their quality. The finest table grapes for many years to come will be the least profitable to the producers, until we are 
able to educate the masses in the large cities to make the proper distinction between fruit and fruit in regard to appearance and quality. It has been amusing to me to speak about grapes with fairly and well-educated people in the city, and finding that most of them know the Concord by name, any black grape being the Concord to them. Further, they know that there is a white grape and a red grape, making a total of three varieties of grapes. My friends, I am not joking or even ridiculing these people. These are generally the folks, who buy a fourth variety of grapes, the Californian, which has all colors, is large and showy, costs more than our Missouri grapes, and sometimes tastes nearly as well, but curtails the profits of the Missouri grape grower.

It is useless to say that the Concord is, or has been, a profitable grape, also some seedlings of it, like Worden, Eaton, Pocklington, etc.; in fact, a black grape is more profitable as a market grape than a white or red variety, though Missouri Reisling, Elvira and Niagara have been profitable to me. Rogers's No. 1, or Goethe, has given me the highest price in St. Louis markets; nearly double the price of the Concord, while the quantity per plant was about equal.

My new St. Louis grape has brought fair returns - a seedling of the Concord, tested twenty years; is less foxy, has better color, dark black, more vigorous and productive, bunches more compact, making an excellent wine; standing in quality half way between Concord and Virginia Seedling.

When I finally consider my new Hicks grape, a seedling of decided foreign and native origin combined, as the best and most profitable grape of the day for me, after ten years of severe trial and testing, I seem to be too egotistic, but it is one of the great trio: Campbell, McPike, and Hicks. Time and trials will verify my statement, that I consider it to be the great new Concord of the twentieth century, which place the Hicks will conquer on its own merits alone. In health and growth, it is outgrowing the best; in productiveness, it excels the most productive (in 1897 one vine, three years old, second crop, had about 100 bunches, weighing a little over thirty-two pounds); in quality, equal or superior to the finest of our native black grapes; a wonderful combination of a profitable table, market and wine grape. The quality of the wine has the nearest approach to the finest German or French red wine, more than any other wine I ever tasted.

Now, as I do not expect you to believe such a high statement about the Hicks grape, I will be more liberal than the introducers of new fruits in general; so, to convince all doubting Thomases of the truth of my claims for my Hicks grape, I will give free, to every member of the State Horticultural Society of Missouri, one Hicks grape-vine as a present, for fair trial and honest report, under condition not to propagate for selling plants therefrom, and sending to me correct address, with ten cents in stamps or silver to pay for postage and the trouble of packing, which offer holds good only until December 1, 1899. New York has the profitable Campbell grape; Iowa and Illinois, the beautiful McPike grape. That old, grand Missouri may own and profit by the grand Hicks grape is the sincerest wish of the propagator and sole proprietor. 


\section{HIGH-PRICED GRAPES.}

Grapes that sell for $\$ 1.50$ to $\$ 3$ a pound suggest an Aladdin-like vision to those grape-belt growers who reckoned their net returns at but a few cents a basket. These aristocratic fruits, however, are greenhouse grapes of select European varieties. They are sold only to wealthy buyers, the Rural New Yorker says, and though the market is limited, it is not by any means overstocked, since we import a quantity from England every season.

Most of these grapes are planted out in permanent beds, in grape houses, usually so built that the roots may ramble into an outside border. Well trained and cared for, such vines grow to a great size and produce enormous crops. We saw recently, however, pot-grown vines which were giving fine results. The varieties were Bowood Muscat, a white grape, and Black Hamburg, which is generally regarded as the most reliable black grape under glass. These pot vines, which were grown by H. H. Stevens, of Essex county, N. J., were only one year old, and were fruited in sixteen-inch pots. The fruit began to be cut about the middle of April, and the weight of grapes averaged twelve pounds to the pot.

The pots in which the vines were grown were plunged nearly to the rim in earth upon greenhouse benches, and the vines trained up near the glass. The soil is well-rotted soil broken up with cow manure; sometimes a little charcoal and lime rubbish are added. The vines in question were brought from a cellar, where they had been kept in a dormant condition, in the beginning of December, and started with a temperature of forty degrees. As the buds swell, the temperature is increased to forty-five and fifty degrees; then, when buds are fully opened, the heat is increased to a steady temperature of sixty-five degrees, rising fifteen or twenty degrees higher on sunny days. The pot culture gives an early crop, which reaches the markets when the late crop is over. The bunches are often thinned, especially in the case of certain varieties, that the bunch may be well-shaped. Great care is needed, while the fruit swells and colors, to avoid blemishes, which will diminish its value, and as each variety has peculiarities of its own, which must be studied individually, experience is required to grow firstclass fruit successfully.

\section{PRESERVATION OF FRESH GRAPES.}

A recent bulletin of the school of agriculture of Scandicci, Italy, describes experiments made by Professor Marchi for the keeping of grapes fresh during the winter. A certain quantity of grapes, comprising different qualities, was hung up in a cool and dry place, all damaged berries having been previously removed, and a second lot was packed in dry, pulverized peat, in wooden boxes. At the end of four months the grapes that had been hung up were decayed and had dropped off; on the other hand, those that were packed in the boxes were found to be in an excellent condition. Another method consists in gathering the bunches with some of the stem attached, and immersing their tips in bottles containing pulverized charcoal. Experiments were also made for preserving seed potatoes by using corn shucks, sawdust, peat, and very dry sand. The three first named gave the best results, while the sand proved a failure.-Practical Fruit Grower. 


\section{GRAPES IN COLD STORAGE.}

Perhaps these ought to be divided, from the standpoint of the cold-storage man, into two classes - that class represented by the Concord, and that represented by the Malagas, the latter being less juicy than the former, and a firmer meat. The Concord comes to this market anywhere from September 1 to October 31 ; probably the heaviest shipments reach us in the latter part of September; it all depends on the season. For cold storage they should be well selected and very carefully packed. You cannot pick them as you do for immediate use. There must not be any crushed or bruised grapes, nor must there be any decayed ones; for if there are there is bound to be trouble from decay. If one basket of grapes gets to rotting it is liable to taint the whole lot, not so much in taste as in smell.

Malagas are a trifle later in getting to this market than others, but they continue to come until very cold weather. They, too, must be packed very carefully, but not so much so as the Concords; for they are firmer, and will stand more pressing. But they must not be crushed or broken.

Concords cannot be kept very long in cold storage. Thanksgiving day seems to be a generally accepted limit; and a great many of them, particularly the more juicy ones, will not keep that long.

Malagas will usually keep longer and are usually finally disposed of during holiday time, but I am reliably informed they can be kept longer in some instances.

All grapes lose a great deal of their fine flavor in cold store, and acquire a flatness that is rather disappointing. Malagas hold their flavor rather the best.

The temperature at which grapes should be held seems to be a matter of opinion only, and ranges from thirty-two degrees to forty degrees. My observation is that the forty-degree grape comes out of storage with a nicer flavor than the thirty-two degree; this is more pronounced in the Concord than in the Malaga. The lower-named temperature seems to have less effect on the Malaga than on the Concord, which, I am inclined to think, is due to the juiciness of the latter, although the chemical ingredients of the juice may be the cause. We have not much reliable data on the subject of grape storage. The cold-storage man does not consider it good storage, and will not take them if he can get out of it, and then will only guarantee temperature. For this reason the subject has not been given the scientific attention it needs. But now, as the cold-storage business is spreading and competition for business gets more closely drawn, all kinds of goods are being more carefully noted, and grapes will undoubtedly receive more attention.-Ice and Refrigerator.

\section{GRAPE JUICE.}

Ferment is decay, decomposition, rot. Alcohol is only produced by decay, decomposition, rot. Hence fruits, in fermenting, produce alcohol. As the human stomach was never intended to receive carrion, swill, rotten, decayed or fermented products only on risk of sickness, contamination, death, therefore the human stomach was not intended to receive alcohol, excepting under similar risks. The housekeeper, under a modern discovery, heats carefully selected and prepared fruit to the boiling-point, and, sealing it in air-tight cans, prevents ferment, decay, decomposition, rot, alcohol. If, by chance, a can or two is not well 
sealed, the housekeeper discovers it by the ferment, and she immediately heats the product to stop decomposition. If not discovered soon enough the fruit is soured, spoiled, decomposed, smells of alcohol, and has developed alcohol, and no housekeeper would set it on her table or feed it to the vilest tramp, unless to do him injury. The juice of ripe grapes, pressed out and heated, or heated and then pressed out, if sealed up while at the boiling-point, will keep in a cool place without developing ferment, decay, decomposition, rot, or alcohol, and is a valuable food product. If a can leaks air and ferments, developing decay or alcohol, it is no more fit for food than the decomposed fruit referred to above, and no. housekeeper would set it before a family or friend, excepting to injure them. The stomach and the brain are partners; abuse the stomach and you affect the brain; a child eats too much sweets, nausea is produced, the brain reels, and only relief of the stomach will clear the brain. The glutton eats to distention, his brain becomes stupid, and he sleeps in his chair, with his napkin still before. him and his fingers greasy. A little taint in food, even the sight or smell of a disagreeable or disgusting thing, will of ten set the brain whirling and "turn the stomach." I myself once fainted dead away simply studying the pitiful pictures: of deformity displayed in a free pocket memorandum-book sent out by a medicine firm.

Now, why should man desire to abuse the wonderful mechanism of his body? It will at best cease some day; the last heart-throb will come at a future hour, we know not when; why shorten it by abusing those wonderful and devoted servants, stomach and brain, by introducing rot, decay, ferment, alcohol? If fermented canned or uncanned goods are not fit for food, how can the fermented juice from fruit, or grain, or leaf, or herb, be fit to put into the stomach, to the great detriment and risk of both it and the brain? The freshly expressed juice of the grape is a proper, useful, nutritious, healthful and delightful food or drink. But it cannot be held without ferment, decay, decomposition, rot or alcoholic development unless it be heated to the boiling-point and at once hermetically sealed. Then it is better than canned grapes, for it is free from the objectionable seeds and skins. It is easily prepared; responsible writers named in this work testify to that, and I can add my own testimony, both as to ease of putting up and pleasure of using. I have declared my belief that in time it would be sold on the streets, fresh, sweet, non-alcoholic, like milk, and as cheaply. Some may fear that "topers" would buy it and let it ferment. This is possible, but should not prevent its honest use.

I would advise those who have grapes when the price is low to gather when fully ripe; snip off with scissors all defective berries; wash the bunches; some strip from stems; then press through a cider or jelly press; strain and heat the juice thoroughly, but do not let it boil much; skim, and strain, if necessary; pour at once into cans, bottles, or well-glazed jugs, taking all the care and precautions used in canning, and seal up perfectly at once.

Some prefer to heat all before pressing. This is all right, but requires larger vessels, and the hot grapes are more trouble to handle in pressing, and the juice must be again heated, or it will not go into the cans at a high enough temperature. Some add sugar; this is unnecessary until the time of use.

After the cans have cooled, examine, and, if tight, put away in cellar or cool place; better if dark, also. Under no circumstances use grapes that are soured or decaying; neither let the work delay after beginning. Do not crush and let stand over night even, and do not put into kegs or wooden vessels to keep. Use granite, porcelain lined, or stoneware in heating. Do not heat in copper, tin, brass, or iron, especially galvanized iron. Be particular, be nice, in the whole, 
operation, if you want success. And do not let any one persuade you for the smallest fraction of a minute that ferment, decomposition and rot will improve it. Use it fresh from the cellar or ice-box, clear or diluted, sweetened or not, at meals or between. It can also be made into jelly, or cooked with apples or other fruit.

These correspondents put up unfermented grape juice for family use:

Allison, T. W., Florence, Marion county.

Anderson, Jas., Leonardville, Riley county.

Baird, Wm., Vesper, Lincoln county.

Baum, G. M., Washington, Washington county.

Barnes, J. T., Beloit, Mitchell county.

Chase, R. C., Hiawatha, Brown county.

Cook, C. C., Bradford, Wabaunsee county.

Dickey, C. E., Irving, Marshall county.

Diehl, E. P., Olathe, Johnson county.

Gardiner, C. C., Bradford, Wabaunsee county.

Griesa, A. C., Lawrence, Douglas county.

Griesa, A. H., Lawrence, Douglas county.

Griffing, W. J., Manhattan, Riley county.

Guest, Thos. H., Grafton, Chautauqua county.

Holsinger, F., Rosedale, Wyandotte county.

Jurgens, Frank, Scott, Scott county.

Keller, Johnson, Arkansas City, Cowley county.

Kimble, Sam'l, Manhattan, Riley county.

Montgomery, Bert., Troy, Doniphan county.

Oberndorf, A., jr., Centralia, Nemaha county.

Pimm, John, Enon, Barber county.

Ross, J. C., Havana, Montgomery county.

Spohr, G. E., Manhattan, Riley county.

Stayman, Dr. J., Leavenworth, Leavenworth county.

Taylor, C. H., Eskridge, Wabaunsee county.

Tucker, W. H., Effingham, Atchison county.

Walters, W., Emporia, Lyon county.

White, D. D., Enon, Barber county.

\section{GRAPES AS MEDICINE.}

Doctor Dupoury, a French physician, celebrated for his scientific investigations in dietary matters, in an article printed in a Paris journal, considers the hygienic value of fruits. He divides fruits into five classes, each of which possesses a special hygienic value - the acid, the sweet, the astringent, the oily, and the mealy. To the first, including cherries, strawberries, raspberries, gooseberries, apples, peaches, lemons, and oranges, he accords great merit. Cherries, however, he prohibits entirely to those affected with neuralgia of the stomach. Strawberries and raspberries he recommends warmly to those of bilious, plethoric and gouty temperament, and denies them to those on whom diabetes is present or suspected. Of the sweet fruits, he considers that plums are of special hygienic value, and even a preventive in gout and, particularly, rheumatism. To the grape he accords the very first place. $\mathrm{He}$ is an ardent advocate of what in Europe is called the grape cure. In this cure grapes for several days form the exclusive aliment. The patient commences with the consumption of from one to 
two pounds daily, with a gradual increase to eight or ten pounds. After a few days of this diet a marked improvement in the general health is noticeable. The appetite improves, the digestion becomes easy and rapid, and increased capacity to withstand the fatigue of outdoor exercise is noticeable. The grape cure is particularly recommended to the anemic, dyspeptic, and consumptive, in diseases of the liver, and in gout.-California Fruit-grower. 


\section{DISEASES AND INSECTS AFFECTING GRAPES.}

Unhealthy parentage from which cuttings were taken and very poor or overrich soil help to develop disease. Overbearing also causes debility and a diseased condition. Heavy, wet soil or stagnant moisture is also a source of disease. Too much washing-suds to vines on city lots often causes harm.

Almost the only disease causing any uneasiness in our state is black rot, which can be largely controlled by bagging and spraying.

Insects are not bad; at no time in any part of our state have they caused alarm; a few flea-beetles, a fow aphides, a little scale-nothing serious.

Grasshoppers, in some parts of the state, cut the stems and cause the fruit to fall. Wasps, English sparrows, orioles and perhaps some other insects and birds perforate the berries, thus attracting bees, and causing them to be wrongfully accused.

Birds are readily scared away by tying a hawk-kite to a string six to ten feet long, at the end of a pole, and fastening the pole at an angle of forty-five degrees (this keeps the string from winding about it) to something upright-a tree or post. Several of these kites, which are cheap, will keep birds from any crop of grapes, berries, cherries, etc. They will also keep poultry off the garden or away from any spot where their presence is annoying.

\section{ANTHRACNOSE.}

The anthracnose, or scab (Sphaceloma ampelinum), is a very serious fungous disease. It is most apparent on the fruit, where it makes a hard, scabby patch. Its most serious work, however, occurs on the stems of the clusters, and on the young growth, where it makes sunken, discolored areas, and where it interferes seriously with the growth of the parts. It is not so easily controlled as mildew or black rot. Careful attention to pruning away all the diseased wood and burning it will help in controlling the disease. Before growth starts, spray the vines, trellis and posts with strong sulphate of copper solution. After the leaves open, use the Bordeaux mixture.-Bailey's Cyclopedia of American Horticulture.

\section{POWDERY MILDEW OF THE GRAPE.}

This mildew flourishes best in dry, hot weather, and prefers the hybrids of the European wine grape, Vitis vinifera. It attacks the foliage, shoots, and fruit. The leaves become yellowish, changing to brown, with whitish patches of the ruiting threads of the disease on the surface, usually the upper surface. The whitish patches turn light-brown later in the season, as the winter spores develop. On the fruit, brownish spots appear, which may run together, checking the growth of that part and causing deformed berries, which soon decay.

Remedy. - The treatment recommended for black rot of the grape will also apply to powdery mildew. 


\section{BLACK ROT OF THE GRAPE.}

The circular, bright reddish-brown spots on the leaves are the first indication of black rot. In these spots black pimples soon appear, which contain the spores of the disease. As the spores ripen and are carried by wind or rain to the other leaves or the fruit, they start new points of attack. On the fruit the disease first appears as small brown spots, which enlarge, causing the berry to assume a rotten appearance, and later to shrivel up and turn black. As the berry dries the skin becomes arranged in folds or furrows, corered with black pimples; this is characteristic of black rot. In the pimples are the winter spores, which start the disease anew the following spring.

Remedy.-Burn all grape trimmings and diseased berries and rubbish in the vineyard. Spray with Bordeaux mixture as soon as the leaves appear, and again in ten days or two weeks; just after blossoming give a third spraying, and two weeks later the fourth. If another application is necessary, it may be given two weeks after the fourth.

\section{GRAPE-VINE FLEA-BEETLE}

Is found in almost all parts of the United States, on wild and cultivated grapevines. Although this beetle has received the specific name of chalybea, meaning steel blue, it is exceedingly variable in color. "The most common tint of the upper side is a glossy, deep, greenish blue, the under side is a dark green, and the antennæ and feet are dull black. The body is oblong oval, and the hinder part of the thorax is marked with a transverse furrow. It measures rather more than three-twentieths of an inch in length." Two broods usually appear in a season - the first in April or May, according to location, and the second in July and August. I have not heard of any section where they have been very destructive, but they will probably become so unless some precaution is taken against their further advance. Hand picking is the surest mode of destroying them: It is said, however, that if a strong solution of potash is thrown over the vines it will destroy them. They seldom bother to such an extent but that they could be easily gathered by hand, or shaken from the vines and crushed by the foot.

\section{THE FLEA-BEETLE ON GRAPES.}

The flea-beetle, or steel bug, which makes such ravages in the vineyard, is a close relative to the black and striped beetles which infest turnips, cabbage and radishes as soon as they begin growth in spring. It is a very small, shiny beetle, ranging in color from a steel blue to metallic green and purple, according to circumstances; in size it is only about a third that of the potato-bug. It appears early in the spring, just when the buds are swelling, and, if allowed to work undisturbed will soon destroy the buds on a large number of vines. They do not always kill the vines, as most of them have latent buds to take the place of those destroyed, but with the latent buds no fruit-buds appear; consequently the crop is lost, as well as much of the vitality of the vines. When the leaves begin to unfold the beetles lay their eggs on the under side of them, and these soon hatch out in the form of brown grubs, which feed on the grape leaves; when fullgrown they go into winter quarters, to emerge in the form of flea-beetles the following spring. Sometimes a great number of the bugs appear, and then for 
several years none will be seen; this makes grape growers become careless, so that sometimes much damage is done before it is discovered. Paris green has proved an effective remedy, but it must be applied several times during the season; if the beetles can be destroyed before the eggs are laid there will be no further trouble during that season. One-fourth of a pound of Paris green in forty gallons of water is strong enough for the purpose, and should be applied with a sprayer. The buds must be kept well coated with the poison.

One grower recommends a little thicker mixture, to be applied to the vines with a paint brush, the vines being first tied to the trellis, to make the work easier. The same solution will kill the grubs if they begin to work on the vines.

\section{SPRAYING GRAPES A GREAT SUCCESS.}

I have the pleasure to state that for the past eight or ten years, we have annually sprayed our vineyards - some eight acres - with the Bordeaux mixture, namely, six pounds bluestone, four or five pounds best fresh lime, to fifty gallons water, using a double-action force-pump with two nozzles. We use the Vermorel and Deming nozzles, somewhat preferring the latter, and make three (usually), sometimes four, applications each season, with result that we made almost perfect crops each year, whereas, before we began spraying, we lost the greater part of the crop by black rot.

The best treatment, probably, is to spray before buds push in spring with simple solution of bluestone (sulphate of copper), one pound to thirty gallons of water, being sure to reach every point on the vines, the trellis, and the posts; then with Bordeaux mixture, made as above, just before flowering time. This catches the first crop of rot spores that develop in round brown spots on the leaves; then, again, with Bordeaux mixture, as soon as young grapes are as large as duck shot, which in ordinary seasons will save the crop here. But if the weather is very moist and sultry, spray again in nine days-not longer-after the third spraying, and the work is done.

Be careful never to spray a vine when in blossom; it will blast the fruit. By the time the fruit will be ripe the mixture will all be washed off the fruit; so nothing remains to spoil its appearance in market. Care should be exercised to see that the spray is fine (fog-like), not in drops, secured by having pump in perfect order, and pumped hard, and that all surfaces of leaves and fruit be reached by the spray, and that the mixture be fresh.

This treatment vanishes mildew, anthracnose, black rot, and about all insects from the vineyard that prey upon the foliage and fruit, and causes the vines to grow and mature wood for next season far better than when not sprayed.

It is patent to every one that a vineyard of equally good varieties which produces perfect crops without spraying is far more satisfactory and profitable than one which must be sprayed three times annually all its life. Many of the best French vineyards, in the regions of France, where the black rot and mildew have obtained a foothold, are diligently experimenting in hybridizing resistent, rot- and mildew-proof American varieties with the best and healthiest vinifera varieties, and are making very encouraging headway, as is reported in the leading viticultural journals of that country, such as Revue de Viticulture, published in Paris. -T.V. Munson. 


\section{ENEMIES OF THE GRAPE.}

The larvæ of upward of fifty moths feed on the foliage of the grape. Many of these are rare, yet many others are occasionally destructive. The large green or brownish, usually horned, sphingid larvæ and certain cutworms are oftenest the cause of important damage. The larvæ of some ten species of hawk-moths or sphingids occur in the grape, and nearly all are widely distributed. The one most frequently met with is the achemon sphink (Philampelus achemon). The sphinx larvæ strip a branch at a time completely, and are therefore easily noted. They are not often very abundant, and the injury is not usually great, except in the case of young vines which may be entirely stripped and killed by a single larva. Hand picking is ordinarily the safest and most satisfactory remedy.

Climbing cutworms have at times proved very destructive to the buds and foliage of vines, and in northern New York and in the raisin district of Fresno, Cal., as much damage has been done by them as by any other insect enemy. Of the several species which in different localities have been troublesome, the worst record may be assigned to the dark-sided cutworm (Agrotis messoria) and the variegated cutworm (A. saucia).

Cutworms remain concealed in the ground during the day and climb up and strip the vines at night. They may easily be destroyed by the use of a poisoned bait of bran, arsenic (or Paris green), and water, preferably sweetened with a little sugar. It should be distributed about the base of each vine in the form of a mash, a hardful or so in a place, according to C. L. Marlatt, of the United States department of agriculture, from whose report on insect enemies of the grape the foregoing is learned.

\section{THE APHIS.}

The aphis, or green fly, often called plant-louse, is a very small insect. The rapidity with which they multiply is truly astonishing, as in a few hours after they make their appearance upon a plant it will often become entirely covered with them. They usually attack only the ends of the young shoots and more tender leaves, feeding upon the juices of the plant, which they take from it in such quantities as to cause those parts which they infest to soon wither and die. Moist, warm weather seems to suit them better than any other. They frequently attack young vines in the nursery, and often entirely destroy the terminal shoot as well as the young laterals, thus severely checking the growth of the vine. Vines grown under glass are more subject to the attacks of the aphis than others, but here they are readily destroyed. But when they attack plants in the open air, it is quite another thing. The only effectual method that I have found is to go over the young vines and, holding the infested shoot in one hand, with a good, stiff brush, clean off the aphides. A few upward strokes will usually kill every one, without materially injuring the young shoot. A good leather glove will be needed, to protect the hand that holds the shoot. The generic name of this insect is Aphis; the specific name is usually taken from the name of the plant upon which it is found; thus, when found on the vine, it is called Aphis vites; when on the apple, Aphis mali, from malus, the specific botanical name of the apple.

The larvæ of a small, spotted insect called the ladybird feeds upon the aphides, devouring vast numbers of them. The ladybird is the gardener's friend, and should never be killed if it can be avoided. These little beetles are usually red or orange yellow, with small black spots; some kinds have only three spots; others have as many as nine. They are very common, and many has been the crime that has been laid to them of which they were entirely innocent. 


\section{A TROUBLESOME INSECT-THE ROSE-BUG.}

With the blooming of the grape, an awkward, long-legged, light-brown beetle, about one-third of an inch in length, frequently appears in enormous swarms, at first devouring the blossoms, then the leaves, reducing them frequently to mere skeletons, and later attacking the young fruit. By the end of July these unwelcome visitors disappear as suddenly as they come.

Though now distinctively a grape pest, it was first known as an enemy of the rose, whence its name, "rose-bug," or rose-chafer. It attacks also the blossoms of all other fruit-trees and of many ornamental trees and shrubs, and, in fact, in periods of great abundance stops at nothing - garden vegetables, grasses, cereals, or any green thing. At such times plants a ppear a living mass of sprawling beetles, clustering on every leaf, blossom, or fruit.

From a bulletin by C. L. Marlatt, of the department of agriculture, it is learned that the beetle thus described occurs from Canada southward to Virginia and Tennessee and westward to Colorado, but is particularly destructive in the eastern and central portions of its range, notably in New Jersey, Delaware, and to a less extent in New England and the Central states.

As remedies, the arsenicals are available only when the beetles are not very numerous. Otherwise, their ranks are constantly recruited by newcomers, and, under these circumstances, all insecticides, however effective ordinarily, are unavailable. When this is the case, the only hope is in collecting the beetles, or in covering and protecting plants with netting, or, later, in bagging grapes. Advantage may be taken of their great fondness for the bloom of spirea, and rows of these flowering shrubs may be planted about the vineyard to lure them and facilitate their collection.

They may be gathered from these trap plants, or the grapes themselves, in large hand beating nets, or by jarring into large funnel-shaped collectors, on the plan of an inverted umbrella. The latter apparatus should have a vessel containing kerosene and water at the bottom, to wet and kill the beetles.

\section{THE ROSE-CHAFER.}

This beetle measures seven-twentieths of an inch in length. Its body is slender, tapers before and behind, and is entirely covered with very short and close ashen-yellow down; the thorax is long and narrow, angularly widened in the middle of each side, which suggested the name subspinos $\alpha$, or somewhat spined; the legs are slender, and of a pale red color; the joints of the feet are tipped with black, and very long. This is one of the most common and destructive insects known to infest the grape in this country. In some parts of the Eastern states it makes its appearance in such vast numbers that it is impossible to stay its ravages. It does not seem to be at all fastidious in regard to its food, as it feeds indiscriminately upon nearly all kinds of plants. If it has a choice, it is not a very particular one, as I have found it feeding upon the flowers of the cherry, grape, oxeye daisy, sumac, rose, and upon all the different species and varieties of the spirea; and when the flowers of these are gone it will attack the leaves. I had, one season, about 100 cherry trees entirely stripped of their leaves by this voracious little pest. It prefers, however, the flowers of plants to their leaves, and it usually makes its appearance in the spring, about the time the grapes come into bloom. It eats the flowers with avidity, and when it appears in large numbers makes short work of the entire crop. 
There are a number of remedies recommended for the rose-chafer, but I know of none better or more effectual than that of catching them by hand and killing them. They can be caught very rapidly by taking a large cup or basin, with a little water in it, and holding it under the insect; giving the cluster of flowers a slight jar, the bugs will immediately let go their hold and fall into the dish. When a quantity have been caught, throw them into fire, or pour hot water upon them. I have followed this simple plan for several years, and though I have not been able to annihilate them, their numbers have not increased.

\section{VINE SCALE.}

The vine scale (Coccus vites) is occasionally met, but it is not common. To the unassisted eye it appears to be nothing more than a small scale, without the least appearance of life. The scale is the shell or covering of a very minute insect that pierces the bark of the young shoots and sucks its juices. A strong solution of potash (say one pound dissolved in two gallons of water) will quickly destroy them. It is well to wash the stems of all vines in gardens with potash water every winter, as it would destroy insects that make their nests in the crevices of the bark. That portion of the solution that falls upon the ground is not wasted, because it furnishes the vine with potash, which is one of the most valuable ingredients of all fertilizers. There are several other species of vine scale or Coccus which may be occasionally found. The Coccus adonidum, or mealy bug, sometimes attacks the vine when grown under glass, but it generally confines itself to other plants. Diluted soft soap, or potash dissolved in water, will usually destroy all kinds of vine scale. 


\section{A FEW GRAPE RECIPES.}

Canned Grapes.-Take ripe grapes, pick from the stems, and wash well. Put them into cans and place the lid on loosely. Set the cans on cloths or a wooden rack in a boiler, surround the cans with water two-thirds their height; boil until thoroughly cooked. Fill up shrinkage from one can, or add boiling water or boiling syrup, of any strength desired. Screw the tops down, or seal, and set away.

Canned Grapes (to use).- They are good directly from the can or made into pies; or they may be used, as plums or raisins, in cake and pudding. They are good in a roly-poly pudding, boiled or baked.

Grape Jam.- Pulp the grapes; put the skins in one basin and the pulps in another. Pour the pulps into a porcelain-lined kettle, and bring to boiling-point; press them through a colander, add the skins, and measure. To every pint allow a half-pound of sugar. Put the sugar and liquid back into the kettle, and boil rapidly twenty minutes, stirring occasionally to prevent scorching. Pour into tumblers or jars and seal the same as fruit jelly. Or, after boiling the twenty minutes, the whole may be pressed through a sieve to make it fine. (Mrs. Rorer.)

Grape Jrm.-Stem and wash ripe grapes. Then pulp them, putting the skins in a vessel by themselves. Cook the pulp in a preserving kettle and press through a sieve or colander to remove the seeds. Now add the skins, weigh all, and add three-fourths the weight in sugar. Cook all together slowly, stirring well for an hour. This is about the best way to put up grapes for winter use.

Green Grape $\mathrm{Jam}$.-This is made precisely the same as grape jam, using three-quarters of a pound of sugar to every pint of grapes. (Mrs. Rorer.)

Grape Jelly or Jam (to use).-Nice on the table as sauce; also good in layer-cakes or sandwiches.

Jelly. - For this use ripe Concord, Isabella or Clinton grapes. They should be freshly picked, and with the bloom on. Put the grapes into a stone jar; stand it in a kettle of cold water; cover the top of the jar, and heat slowly until the berries are soft. Now put a small quantity at a time into your jelly-bag, and squeeze out all the juice. Measure the juice, and to each pint allow one pound of granulated sugar. Turn the juice into a porcelain-lined kettle, and stand over a brisk fire. Put the sugar into earthen dishes and stand in the oven to heat. Boil the juice rapidly and continuously for twenty minutes, then turn in the sugar hastily, stirring all the while until the sugar is dissolved. Dip your tumblers quickly into hot water, watch the liquid carefully, and, as soon as it comes again to a boil, take it from the fire and fill the tumblers. If the fruit is overripe, your jelly will never be firm, no matter how long you boil it. Follow the directions carefully and you will never fail. (Mrs. Rorer.)

Green Grape Jelly.-Fox grapes are the best for this. Stem the grapes, put them into a porcelain-lined kettle, barely covered with cold water, cover the kettle, and boil slowly until the fruit is very tender; then drain them through a flannel jelly-bag - do not squeeze. To every pint of this juice allow one pound of granulated sugar. Put the juice into a porcelain-lined kettle, and bring it 
quickly to a boil; add the sugar, stir until the sugar is dissolved, then boil rapidly and continuously until it jellies, skimming off the scum as it comes to the surface; twenty minutes is usually sufficient, but some times $I$ have boiled it thirty-five minutes before it would jell properly. It is wise to begin testing after fifteen minutes' boiling. To do this, take out one teaspoonful of the boiling jelly, pour it into the bottom of a saucer, and stand it in a cold place for a moment; then scrape it one side with a spoon-if jellied, the surface will be partly solid; if not, boil a few minutes longer, and try again. As soon as it jellies, roll the tumblers quickly in boiling water, then fill them with the boiling liquid. Stand aside until cold and firm (about twenty-four hours). Then, if you have jelly tumblers, put on the lids; if not cover with two thicknesses of tissue paper, and paste the edges of the paper down over the edge of the tumbler. Then moisten the top of the paper with a sponge dipped in cold water. This moistening stretches the paper, so that when it dries again it shrinks and forms a covering as tight and smooth as bladder skin. I do not recommend jelly being covered with brandied paper, as in my hands it has never been satisfactory. The jelly, in cooling, forms its own air-proof covering, and if the top of the tumbler be well secured, it is all that is necessary. Keep in a cool, dark place. (Mrs. Rorer.)

Green Grape Jelly.-Express the juice either before or after cooking preferably after. For each pint of juice add one pound of best granulated sugar. Boil hard and fast about twenty minutes or more - you can tell only by testing.

Grape Marmalade.-Made like grape jam, only use pound for pound of sugar, and'boil until stiff.

Grape Pie.-Make like any other fruit pie, using either green, ripe or canned grapes. Be sure to sweeten well, as the heat "brings out the acid."

Pickled Grapes.-Fill a jar with alternate layers of sugar and bunches of nice grapes just ripe and freshly gathered; fill one-third full of cold vinegar, and cover tightly. (Mrs. C. T. Carson.)

Spiced Grapes.-Five pounds of grapes, three of sugar, two teaspoons of cinnamon and allspice, half teaspoon of cloves; pulp grapes; boil skins until tender, cook pulps, and strain through a sieve, add it to the skins, put in sugar, spices and vinegar to taste; boil thoroughly, and cool. (Miss Mae Stokes, Milford Center.)

Grape Syrup.-Mash the grapes and stand aside in a warm place for four days. Cover to keep out dust and insects. Then turn into a jelly-bag and let drip slowly. If you wish it very clear, filter through filtering-paper. Measure the juice, and to every pint allow two pounds of granulated sugar. Mix the juice and sugar together until only a small portion settles to the bottom, then pour it into a farina boiler, place over the fire, and the heat of the water as it boils around will dissolve the sugar. When this has been thoroughly effected, take it from the fire and stand aside to cool. When cold, put into small bottles, fill them to the top, cork tightly, seal and keep in a dark, cool, dry place. Be very careful that you use only porcelain or granite articles in the making of syrups, as the acids of the fruits will act upon metal and change the bright red color to a purple. Use a wooden spoon in stirring. Strong heat or boiling also destroys the color and flavor of the syrups. (Mrs. Rorer.) 


\section{N D E X .}

America, grape in..................... 3

American, origin of....................

، evolution of................... 6

Anthracnose .......................... 127

Aphis............................. 130

Arbors.............................. 16

Area of greatest development........... 3

Bagging, addresses of patrons............. 17

“ how to do it.................. 18

“ Frank Holsinger on.............. 19

“ it pays........................ 29

Bees, do they injure grapes?............ 115

" " " " Abbott....... 115

„ . $\quad$ “ $\quad$ “ Langstroth... 115

‘ “ ‘ “ Cook........ 116

„ ‘ ‘ “ McLain...... 117

Black rot.............................. 128

Bull, Ephraim W., frontispiece.

Canning grapes...................... 133

Canned, to use........................ 133

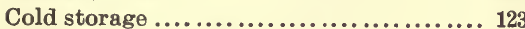

Concord grape, original vine ........... 15

Culture by -

Buckman, A. H.................... 92

Chambers, S. W.................... 106

Chandler, M. E................. 93, 111

Cutter, William................ 106, 108

Entsminger, A. L.................... 93

Fisher, E. P...................... 107

Mead, W........................... 105

"Missouri way".................... 27

Miller, Samuel..................... 102

Moyer, Peter......................... 106

Spear, Geo. J....................... 97

"Strawberry Culturist"............. 96

Cutworms............................ 130

Discussions on culture.............. 94, 107

Diseases .............................. 127

Enemies............................ 130

Extracts from -

"American Cultivator" .............. 106

Prof. L. H. Bailey ............... 3, 6, 127

"California Fruit-grower" .......... 125

Mrs. Carson........................ 34

"Farm and Fireside"................ 9

M. M. Frizelle...................... 14

"Green's Fruit-grower" ........... 27, 105

"Ice and Refrigerator".............. 123

Newlin, Chas. E................... 5

"Orange Judd Farmer ".............. 26

F. H. Hall ...................... 112

T. V. Munson ........... 97, 99, 111, 129

"Practical Fruit-growier" ........... 122

Mrs. Rorer................... 33, 134
Extracts from -

"Rural New Yorker" ............... 122

"Rural World"....................... 8

Miss Mae Stokes.................... 134

Henry Wallis...................... 120

Prof. J. C. Whitten..........4, 12, 27, 29

Fox grape, northern...................

Girdling vines ................. 12, 13, 14

Growing, in cities .................... 16

“ in south Kansas................ 90

High prices......................... 122

Insects............................ 128

Aphis............................ 130

Cutworm....................... 130

Flea-beetle......................... 128

Rose-bug.......................... 131

Scale............................... 132

Juice, unfermented.............. 3, 27, 123

“ who puts it up.................. 125

Kansas vineyards, statistics ............. 7

Medicinal qualities..................... 125

Methods of old world................... 3

Mildew, powdery...................... 127

Overbearing ............................ 18

Preservation of fresh................... 122

Profitable........................... 120

Propagation, by seed................... 8

. by cuttings ............... 8

، by layers................. 9

، by grafting ............... 10

، setting vines.............. 98

Pruning.................... 10, 11, 14, 15

Recipes, grape...................... 133

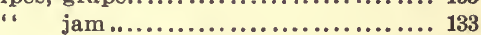

، green grape............... 133, 134

، to use ....................... 133

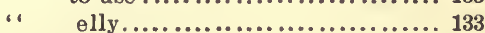

، marmalade................... 134

، pie ........................... 134

.. pickled ......................... 134

، $\quad$ spiced......................... 134

، syrup....................... 134

Ripening, order of ................... 27

River bank grape.................... 5

Spraying ........................111, 129

Trellis................................ 16

" to tighten $\ldots \ldots \ldots \ldots \ldots \ldots \ldots \ldots \ldots \ldots, 16$

“ bracing ........................... 16

، Munson's ......................... 99

Varieties, voted list .................. 27

Varieties described :

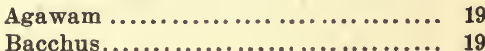

Barry........................... 19 
Varieties described:

Berkmans........................... 19

Brighton ............................. 19

Brilliant ............................ 19

Camṕbell's Early................... 19

Cape............................... 25

Carman ......................... 20

Catawba......................... 20

Centennial .......................... 20

Chandler........................... 20

Champion.......................... 20

Charlton ........................... 26

Clinton............................ 20

Columbian ........................ 21

Columbian Imperial ................ 21

Concord............................. 21

Cottage .......................... 21

Croton............................. 21

Cynthiana.......................... 21

Delaware.......................... 21

Dracnt Amber .................... 21

Duchess............................ 21

Early Ohio........................ 21

Early Victor ....................... 22

Eaton .............................. 22

Eclipse.......................... 22

Eldorado.......................... 22

Elvira ............................. 22

Empire State ...................... 22

Eumelan ......................... 22

Fox, Northern .................... 4

Geneva ............................ 22

Green's Golden...................... 22

Green Mountain.................... 22

Goethe .......................... 22

Hartford Prolific.................... 22

Hayes............................. 23

Herbert ........................... 23

Hertbemont ........................ 23

Herman Jaeger.................... 23

Hicks - Irl R. Hicks................ 23

Ideal .............................. 23

Iona............................. 23

Ives............................... 23

Janesville.......................... 23

Jefferson ............................ 23

Jessica........................... 23

Jewel............................. 23

Lady ............................ 24

Lady Washington .................. 24

Lindley ............................. 24

Logan .......................... 24

Martha ............................ 24

REPORTS FROM GRAPE GROWERS.

Allen connty :

Buck. L. D.. Moran................. 32

Perrenond, L., Humboldt............ 32

Anderson county :

Metcalf, E. T., Colony ............... 32

Newcomb, William, Welda........... 32

Simon, Ebert, Welda .............. 33
Varieties described :

Massasoit.......................... 24

McPike............................ 24

Merrimac.......................... 24

Mills............................. 24

Missouri Reisling................... 24

Moore's Diamond..................... 24

Moore's Early....................... 24

Moyer............................. 24

Niagara............................ 24

Noah............................ 24

Northern Muscadine............... 24

Norton's Virginia.................... 25

Osage ............................ 25

Ozark ........................... 25

Paragon............................ 25

Perkins ............................ 25

Peter Wylie......................... 25

Pocklington ......................... 25

Poughkeepsie Red................... 25

Prentiss........................... 25

Ricketts........................... 24

River Bank ........................ 5

Rochester........................ 25

Rogers's No. 1........................ 22

No. 3..................... 24

No. 4.................... 26

No. $9 . \ldots . . . \ldots \ldots \ldots . . . \ldots . . .24$

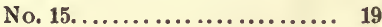

No. 19................... 24

No. $22 . \ldots \ldots \ldots \ldots \ldots \ldots \ldots . . . . . .25$

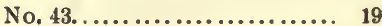

No. 44.................... 23

Rommel ......................... 25

Salem ............................. 25

Schuylkill Muscadel................ 25

Spring Hill Constantia.............. 25

Taylor's Bullitt...................... 26

Telegraph .......................... 26

Ulster Prolific...................... 26

Vergennes ............................ 26

Victoria........................... 26

Warren Neal....................... 23

Wilder .......................... 26

Winchell .......................... 22

Woodruff $\operatorname{Red} . . . \ldots \ldots \ldots \ldots \ldots \ldots \ldots . . . . .26$

Worden ............................. 26

Wyoming Red....................... 26

Vines against buildings................ 16

Vineyards, by George Holsinger.......... 91

“ by T. V. Munson........... 97, 99

by E. W. Geer ............... 103

Why some grapes fail to fruit........ 112, 113

Atchison county:

Gaylord, J. S., Muscotah............ 33

Schletzbaum, Francis, Eden......... 33

Tucker, W. H., Effingham......... 33, 125

Barber county :

Blackmore, C. A., Sharon............. 34

Huff, A. S., Enon ................... 33

Leonhart, B., Kiowa................ 34

Pimm, John, Enon............... 34, 125

White, D. D., Enon........... 17, 34, 125 
Barton county :

Elliott, Geo. T., Great Bend.......... 35 McCullagh, Ben., Ellinwood......... 35 Rediger, Jacob, Great Bend........... 35

Bourbon county :

Saxe, J. B., Fort Scott............. 35

Williams, R. A., Glendale.

35

Brown county :

Chase, R. C., Hiawatha........... 36, 125

Hansen, Neil, Willis.................. 36

Oxley, B. F., Morrill............... 36

Butler county :

Johnson, J. J., El Dorado

Chase county :

Chandler, R. H., Bazaar............. 37

Gamer, Mike, Strong................ 37

Pflagler, Charles, Elk .............. 37

Starkey, F., Elmdale................ 37

Chautauqua county:

Ellexson, Jere, Chautauqua.......... 38

Guest, Thos. H., Grafton.......... 38, 125

McKee, W. P., Cedarvale............. 38

Cherokee county :

Denison, A. S., Columbus.

Stebbins, D. S., Columbus............. 39

Cheyenne county :

Campbell, B. F., St. Francis ......... 39

McCallum, A. R., St. Francis ........ 39

Clark county :

Boone, Chas, G., Ashland........... 39

Clay county :

Arnold, A. D., Longford ............. 40

Macy, I. N., Longford.............. 40

Olsen, Theo., Green ................. 39

Reed, John, Longford .............. 39

Cloud county :

Davis, H. A., Concordia ............. 40

Domony, S. H., Aurora ............... 40

Munger, A., Hollis.................. 40

Cowley county :

Bilsing, J. H., Udall................. 41

Keller, Johnson, Arkansas City .....41, 125

Moncrief, J., Winfield.............17, 41

Crawford county :

Howard, L. M., Girard ............... 42

Whiteside, J. A., Girard .............. 42

Wilson, Alfred, Pittsburg........... 42

Decatur county :

Johnson, P. T., Oberlin.............. 43

Sayles, J. H., Norcatur............17, 42

Street, W. D., Oberlin.............. 42

Dickinson county :

Dunlap, James, Detroit

Engle, A. M. Moonlight. .

Doniphan county :

Montgomery, Bert, Troy...........43, 125

Shoe, L. A., Highland.............. 43

Douglas county :

Griesa, A. C., Lawrence........ 17, 44, 125

Griesa, A. H., Lawrence........... 44, 125

Plasket, William, Lawrence........ 45
Edwards county :

Angus, Harry, Lewis :.

Elk county :

Bolinger, A., Moline............... 46

Lewis, S. D., Howard............... 45

Weathers, J. C., Howard............. 46

Zeiner, Aaron, Elk Falls............ 45

Ellis county :

McIntosh, James, Hays............... 47

Ellsworth county :

McCoy, Geo. W., Wilson............. 47

Finney county :

Sylvester, William M., Garden City.... 47

Ford county :

Mayrath, Nicholas, Dodge City.......

Franklin county :

Brown, David, Richmond............ 48

Patterson, R. D., Ottawa............. 47

Taylor, Isaac M., Richmond........... 48

Suritz, F., Ottawa ............... 48

Geary county :

Cutter, William, Junction City....... 48

Gove county :

Royer, Jesse, Gove.................. 49

Soderstrom, John E., Gove........... 49

Springer, J. E., Gove................ 49

Graham county :

Turck, F. D., Hill City .............. 49

Van Doren, I. M., Leland ........... 50

Gray county :

Emery, J. P., Cimarron ............ 50

Greeley county :

Trueblood, D. M., Tribune........... 50

Greenwood county :

Hinshaw, J. M., Enreka ............. 50

Munger, G. M., Eureka.............. 50

Reiter, Geo. W., Fall River .......... 50

Wiggins, W. H., Lapland ........... 50

Harper county :

Bailey, John, Harper................. 50

Blackburn, W. E., Anthony .......... 51

Chatelaine, Edward, Harper......... 51

Curran, J. C., Curran............... 51

Hamilton county :

Jones, V. B., Syracuse............... 52

Harvey county

Chatelas, Henry, Newton............ 52

Clark, Willlam J., Halstead......... 52

Lehman, David, Halstead............. 52

Nabb, P., Sedgwick ................ 53

Saltzman, A. J., Burrton............ 58

Hodgeman county :

Bastain, C., Wittrup ............... 53

Haskell county :

Vetter, John, Santa Fe.

Jackson county :

Bacon, John M., Soldier............ 54

Dixon, F. W., Holton............... 54

Osborn, F. L., Soldier ................ 54

Williams, J. W., Holton.............. 54 
Jefferson county :

Curry, J. W., Dunavant............ 54

Miller, Lou., Perry................. 55

Roberts, H. R., Perry................ 55

Jewel county :

Gaborsch, M. M., Salem

55

Johnson county :

Beckley, J. C., Spring Hill........... 55

Diehl, E. P., Olathe........... 17, 55, 125

Rhoades, Henry, Gardner............ 55

Kearny county :

Longstreth, C. H., Lakin............. 56

Kingman county :

Coleman, W. R., Kingman........... 56

Kiowa county :

Brown, W. J., Greensburg............ 58

Einsel, A. D., Greensburg ............ 57

Winters, D. E., Haviland............ 57

Labette county :

Beeson, S. M., Angola............... 57

DeGarmo, R., Oswego................. 58

Gordon, Chas. H., Chetopa............ 58

Harrington, Charles, Altamont...... 57

Lane county:

Bradstreet, D. E., Dighton.......... 58

Graves, Jacob, Healy................ 58

Leavenworth county :

Gaiser, E., Lansing. ................ 59

Stayman, J., Leaven worth........ 59, 125

Lincoln connty :

Baird, William, Vesper...........61, 125

Moss, Martin, Lincoln.............. 61

Weidman, J., Lincoln............... 61

Linn county:

Boulware, Mark, Blue Mound......... 62

Fleharty, W. M., La Cygne............. 62

Latimer, J. W., Pleasanton ........... 62

Logan county :

David, J. E., Winona................. 63

Lyon county :

Chambers, A. D., Hartford............. 64

Craig, Thos., Americus............. 63

Overly, D. C., Hartford................ 63

Walters, W., Emporia ............ 63, 125

Marion county :

Allison, T. W., Florence........ 17, 64, 125

McNicol, Jas., Lost Springs........... 64

Meierdircks, J. T., Florence........... 64

Marshall county :

Dickey, C. E., Irving............. 65, 125

Stout, Stephen, Axtell............ 17, 65

Williams, James W., Home .......... 65

$M$

Fern, Charles, Lindsborg ........... 65

Huston, Frank, McPherson ........... 66

Meade county :

Cox, B. F., Meade.................. 66

Vick, Mrs. G. O., Fowler.
Miami county :

Cadwallader, R. H., Louisburg....... 66

Martin, D. M., Osawatomie .......... 66

Stout, P. B., Paola ................. 67

Mitchell connty :

Barnes, J. T., Beloit.......... 17, 67, 125

Detweiler, Samuel L., Glen Elder ..... 68

Stockard, W. B., Beloit............. 67

Montgomery county :

Bouton, Noah E., Cherryvale........ 68

Bowen, P. C., Cherryvale............. 68

Good, Jacob, Coffeyville.............. 68

Kenoyer, F. L., Independence......... 69

Ross, J. C., Havana. .............. 69, 125

Morris county :

Robinson, W. H., Duslap ............ 69

Sample, John E., Beman............. 69

Sharp, James, Parkerville ........... 69

Morton county :

Gordon, John A., Viroqua........... 70

Morgan, L. G., Richfield ............ 70

Nemaha county :

Oberndorf, A., jr., Centralia... 17, 70, 125

Riggs, H. C., Wetmore............... 71

Wilcoe, O. K., Corning.............. 70

Neosho county:

Gardiner, W. W., Chanute............ 71

Record, O. M., Thayer........... 17, 71

Schmoker, G., Urbana.............. 71

Ness county :

Barker, F. A., Ransom.............. 72

Norton county :

Akers, W. H., Cactus............... 72

Alexander, J. J., Norton............... 72

Osage county :

Fine, Godfrey, Maxson.............. 72

Larsen, Olaf, Lyndon............... 72

Lloyd, J. Q., Barclay............... 72

Osborne county :

Short, W. G., Twin Creek ............ 72

Ottawa county :

Geissler, Geo., Tescott............... 73

Steel, J. L., Minnea polis............. 73

Pawnee county :

Dickinson, S. S., Larned.......... 17, 73

Gill, William A., Larned............. 73

Phillips county :

Dutcher, F. T. M., Phillipsburg....... 74

Young, D. F., Long Island.......... 74

Pottawatomie county:

Furman, Isaac H., Onaga........... 74

Weltner, M. D., Westmore and ....... 74

Pratt county :

Ablard, J. J., Lawndale .............. 74

Everhart, J. T., Pratt .............. 75

Rawlins county :

Hinerman, S. S., Chardon........... 75

Williams, J. L., McDonald .......... 75 
Reno county :

Bainum, James, Arlington........... 75

Dunlap, James, Hutchinson......... 76

Hanson, E. B., Olcott .............. 76

Morgan, E., Hutchinson.............. 75

Republic county :

Smith, Fayette A., Belleville......... 76

Rice county :

Bohrer, Dr. G., Chase ............... 77

Hodgson, H. C., Little River ......... 77

Werner, William H., Alden .......... 76

Riley county :

Anderson, James, Leonardville.... 77, 125

Axelton, A. G., Randolph............ 79

Christiansen, N., Mariadahl.......... 77

Griffing, W. J., Manhattan........ 78, 125

Kimble, Sam, Manhattan ......... 78, 125

Spohr, G. E., Manhattan...... 17, 78, 125

Rush county :

Mirick, B. E., La Crosse.............. 79

Newman, W. R., Hargrave.......... 79

Russell county:

ر. ., Russell................ 78

Manners, John H., Luray............ 79

Saline county :

Barker, F. G., Salina .............. 80

Fonek, Henry, Salina ............... 80

Jones, A. W., Salina ................ 80

Scott county :

Jurgens, Frank, Scott.

81,125

Seward county:

Hill, A. C., Seward.

81

Rapp, William, Liberal............. 81

Wright, E. T., Seward ............... 84

Sedgwick county :

Collings, G. W., Wichita............ 81

Shawnee county :

Buckman, A. H., Topeka ............ 83

Johnston, S. R., Wakarusa........... 83

Sheridan county :

Brewster, T. J., Lucerne.
Smith county:

Wells, M. E., Smith Center........... 83

Stafford county :

Campbell, W. M., St. John ........... 84

Pelton, H. E., St. John............... 84

Welch, D. H., Macksville............ 84

Stanton county :

Van Meter, C. E., Johnson ............ 84

Sumner county :

Adams, D. M., Rome.............. 17, 85

Bailey, Geo. W., Wellington.......... 85

Thomas county :

Flood, Isaac, Colby ................ 85

Lacey, M. L., Colby................... 85

Unsigned, Colby.................. 85

Trego county :

Galloway, G. T., Wa Keeney.......... 85

O'Toole, E. W., Collyer............... 85

Wabaunsee county :

Cook, C. C., Bradford............. 86, 125

Gardiner, C. C., Bradford......... 86, 125

Taylor, C. H., Eskridge ......... 86, 125

Wallace county :

Griggs, M. T., Wallace............. 86

Washington county :

Avery, J. B., Clifton ................ 87

Baum, G. M.,Washington...... 17, 87, 125

Brown, Thomas, Palmer ............ 87

Houghton, A. E., Linn ................ 87

Seiferth, F., Strawberry............. 88

Yound, William, Brantford........... 87

Wichita county :

Ford, John C., Leoti ................ 88

Wilson county :

Graham, R. O., Altoona.............. 88

Magill, John A., Roper.............. 88

Woodson connty :

Jones, A. J., Yates Center. ........... 88

Wyandotte county :

Cellar, W. D., Edwardsville.......... 89

Chandler, A., Argentine............. 89

Holsinger, F., Rosedale..... 17, 19, 89, 125 





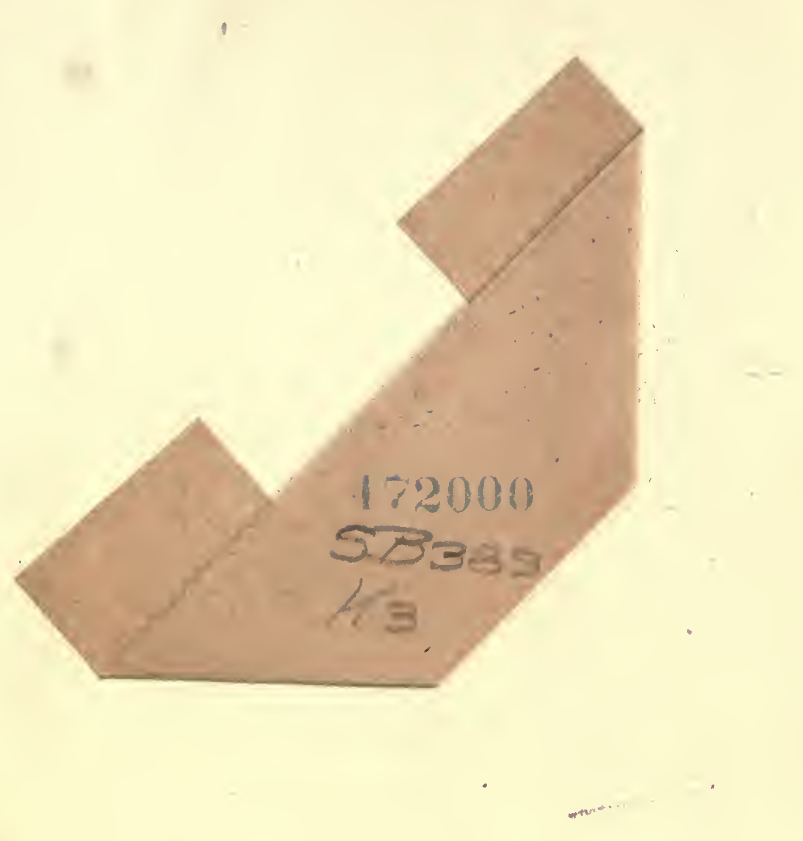


